Portland State University

PDXScholar

$12-22-2021$

\title{
Distribution and Characterization of Rhyolites of the Strawberry Volcanics -- Evolution of a Major Rhyolite Field Associated with Columbia River Basalt Magmatism, Eastern Oregon, USA
}

Chanel Leigh Dvorak

Portland State University

Follow this and additional works at: https://pdxscholar.library.pdx.edu/open_access_etds

Part of the Geology Commons

Let us know how access to this document benefits you.

\section{Recommended Citation}

Dvorak, Chanel Leigh, "Distribution and Characterization of Rhyolites of the Strawberry Volcanics -Evolution of a Major Rhyolite Field Associated with Columbia River Basalt Magmatism, Eastern Oregon, USA" (2021). Dissertations and Theses. Paper 5855.

https://doi.org/10.15760/etd. 7726

This Thesis is brought to you for free and open access. It has been accepted for inclusion in Dissertations and Theses by an authorized administrator of PDXScholar. Please contact us if we can make this document more accessible: pdxscholar@pdx.edu. 
Distribution and Characterization of Rhyolites of the Strawberry Volcanics - Evolution of a Major Rhyolite Field Associated with Columbia River Basalt Magmatism, Eastern Oregon, USA

by

Chanel Leigh Dvorak

A thesis submitted in partial fulfillment of the requirements for the degree of

\author{
Master of Science \\ in \\ Geology
}

Thesis Committee:

Dr. Martin J. Streck, Chair

Dr. John Bershaw

Dr. Jonathan Fink

Portland State University

2021 


\section{ABSTRACT}

The Strawberry Rhyolites constitute a significant rhyolite field among the largest in Oregon. Aerial coverage of approximately $386 \mathrm{~km}^{2}$ and an overall estimated volume of $\sim 67 \mathrm{~km}^{3}$ using a median thickness for each unit. On the other hand, the total volume could be greater than $100 \mathrm{~km}^{3}$ if greater thicknesses apply. The Strawberry Rhyolites, a largely unknown mid-Miocene silicic volcanic rocks, crop out amongst voluminous flood basalt flows of the Columbia River Basalt Group (CRBG) in eastern Oregon. The eruptive activity of the Strawberry Rhyolites is currently constrained to span a period of about 2 million years, ranging from around $\sim 16.2$ to 14.3 Ma.

Mid-Miocene rhyolites are part of the Strawberry Volcanics located within the Malheur National Forest near the town of John Day and were first mentioned in the 1960-70s. Still, neither their distribution, composition nor ages were studied in detail until we started to work in the area. Building on our initial reconnaissance data, the main efforts to map rhyolites took place in the context of three Edmap projects from 20192021 aided by PSU field study students and covering the area of three $7.5 \mathrm{~min}$ quadrangles (Jump-off Joe Mountain, Big Canyon, 1/2 of Logan Valley West, 1/2 of Magpie Table quads) in the NE part of the Harney Basin north of Burns, have shed light on the existence of a diverse set of volcanic units previously lumped into broad single mapping units by earlier regional reconnaissance maps. Hence, there is a much better understanding of the geologic history of the entire northeast margin of the Harney Basin, which plays a significant role in the regional volcanic framework due to this mapping. The focus is to detail the distribution of rhyolite units used for volume estimates, 
determine the composition and petrography, and obtain additional age dates to constrain better the eruptive history and generate a geologic map covering the study area.

This thesis summarizes field work, XRF/ICP-MS geochemistry, thin section petrography, and age date analysis by the ${ }^{40} \mathrm{Ar} /{ }^{39}$ Ar method spanning 2017 to 2020 . Nine distinct rhyolite units make up the Strawberry Rhyolites. These are distinguished by their lithology, petrography, and compositions. This study does include a brief overview of other non-Strawberry Rhyolite units found in the area.

Our study has revealed a rhyolite field that is among the largest in Oregon. A minimum of 10 distinct effusive rhyolite units erupted over a 2-million-year period in addition to one mixed, rhyolite-andesite pyroclastic deposit from $\sim 16.2$ to $14.4 \mathrm{Ma}$ with most ${ }^{40} \mathrm{Ar} /{ }^{39} \mathrm{Ar}$ ages falling in the 15.4-14.4 Ma bracket, but stratigraphically highest undated rhyolite units could be slightly younger. The mapped distribution of rhyolites covers $186 \mathrm{~km}^{2}$, but the estimated original distribution area is likely $\sim 400 \mathrm{~km}^{2}$ with an estimated volume on the order of $100 \mathrm{~km}^{3}$. I present the estimated original distribution area for each rhyolite unit. These estimated areas sum up to a total of $386 \mathrm{~km}^{2}$. Using these estimated areas, the largest rhyolite unit is Wolf Mountain (Trwm), covering about $170 \mathrm{~km}^{2}$, followed by the rhyolite of Three Cabin Spring (Trtcs) at $\sim 158 \mathrm{~km}^{2}$. The smallest estimated area is from the rhyolite of Big Bend (Trbb), covering an area of about $8 \mathrm{~km}^{2}$. Age dates generated through this study and previously acquired are used in combination with stratigraphic field control to place rhyolite units into an eruptive sequence. The rhyolite of Wolf Mountain is the oldest, dating to $16.16 \pm 0.17 \mathrm{Ma}$, and currently, the youngest age acquired is for the rhyolite of Kent Spring at the age of $14.37 \pm 0.02 \mathrm{Ma}$. Thus, some units are likely to be slightly younger than our youngest radiometric age. An estimated volume is generated for 
each unit, with the largest volume obtained for the rhyolite of Wolf Mountain (Trwm), with a value of $\sim 21 \mathrm{~km}^{3}$. The rhyolite of Three Cabin Spring (Trtcs) follows Trwm with an average volume of $\sim 17 \mathrm{~km}^{3}$, both units undoubtedly producing the largest volume out of all the Strawberry rhyolites. The smallest volume average produced is from the rhyolite of Buckhorn Spring (Trbs) at a value of about $0.7 \mathrm{~km}^{3}$. Volumes are calculated using an estimated range of unit thicknesses and the estimated areas for each unit. By clearly defining a volume for each unit gives a better representation closer to their actual distributions. Rhyolites range from low-silica to high-silica and from phenocryst rich containing $>20 \%$ phenocryst to those that are aphyric. All units display glassy-todevitrified lithologies. Phenocryst assemblages are dominated by plagioclase, some units contain quartz, and mafic silicates often are amphibole, biotite, or both. Orthopyroxene occurs in some units in addition to or instead of biotite and amphibole. Through understanding the Strawberry Rhyolite temporal changes in their mineralogy and composition, the SR units defined can have their age dates and volume relationship interpreted. This age and volume relationship may be a precursor in better determining stratigraphy of rhyolitic volcanic units, which aid in closing geologic time gaps throughout history. The trend depicted is that as the rhyolites are younger, the smaller the volume they produce.

The $\mathrm{Nb}$ vs. Zr variation diagram is used to classify samples as I-type or A-type to understand further these implications of the temporal changes in the Strawberry Rhyolites. Our data suggest the following age-volume-composition-lithology relationships. Lower silica, crystal-rich units containing complexly zoned plagioclase, such as Trbs, Trks, erupted early, while crystal poorer and silica-rich units are more 
prevalent later. Units with slight A-type affinities such as Trbs, Trks, and the rhyolitic portion of Ttms, erupted the latest. This sequence is compatible with basalt intruding into crust initiating partial melting to produce rhyolites. This is followed by increased heat input from basalt to support near liquidus rhyolite magmas. Interaction of tholeiitic magmas with rhyolites culminates in the production of A-type-like rhyolites. Evidence for this stage is found in the commingling of Fe-rich andesite and rhyolitic magmas to produce the late tuff of Milk Spring. Interaction of basalts with rhyolites culminates in the production of A-type like rhyolites, supporting the association with hot spot activity. The significance of the Strawberry rhyolite field is highlighted by comparing it to other well-known rhyolite lava flows and fields. Strawberry Rhyolites are now recognized to belong to the rhyolite flare-up associated with the main pulse of the CRBG volcanism. Thus, adding Strawberry Rhyolites to this rhyolite flare-up increased the footprint of this province towards the northwest. 


\section{ACKNOWLEDGEMENTS}

I must say a huge thank you to the many people who have helped make this possible. First, I would like to thank the USGS for approving and funding two Edmap projects for me, the geologic mapping of Jump-off Joe Mountain and the Big Canyon quadrangle. Also, thank you to the PSU Geology Department for their financial contributions to my research by funding me with the Grant-in-Aid. The project was also supported through the National Science Foundation grant EAR-1220676 to M. Streck. Without those grants, this thesis would not have been possible. Thank you, Washington State University geoanalytical lab, for assisting in XRF and ICP-MS. Preparing samples on their campus is truly an educational and enjoyable experience.

Thank you to several of my fellow alumni from Portland State University who contributed to this project, former Edmap mappers and graduate students Shelby Isom, Matt Cruz, and Rachel Sweeten, as well as for Aaron Steiner for all your data collection and reporting on the region. Thank you for all your hard work to all my field assistants: Pierce Thieme, Mariah Dvorak, Chloe Koolhoven, Bonnie Burke, Natasha Dvorak, Lana Jewell, Owen Daly, Kylie Barber, and Kyle White. Thank you, Portland State University field camp summer 2017, 2018, 2019, and 2020 for all your assistance and everlasting memories. Thank you, Emily Cahoon, for providing endless help, guidance, specifically information about the Columbia River Basalts, regional geology, and field techniques that proved enormously insightful. Pierce Thieme, I could not have completed my thesis without your tremendous help. You assisted me immensely in my ability to produce the best map in ArcGIS, as well as endlessly teaching me how to use other related computer programs to generate other map 
features, plots, edits, etc. Without each person's efforts and assistance, this thesis would not be whole. The many years of memories generated throughout all my mapping work are forever held close to my heart.

Many thanks to my advisor, Martin J. Streck, who has consistently provided guidance, assistance, and instruction. For his insight into the geological units present in the field mapping area and insight into field techniques such as identifying minerals in the hand sample, best approach field mapping, collecting data, and reviewing findings while in the field. The patience and kindness he has shown me over the years are cherished greatly.

Finally, I would like to thank my family for supporting me in all my academic endeavors. My family has indeed supported me financially, physically, and mentally. Lastly, I could not have done all of this without the love and support of my chosen family, my amazing group of friends. Thank you for truly being there for me and helping in any way you saw fit. This geologic experience of producing this entire thesis works has been fantastic because of all of you. Thank you! 


\section{TABLE OF CONTENTS}

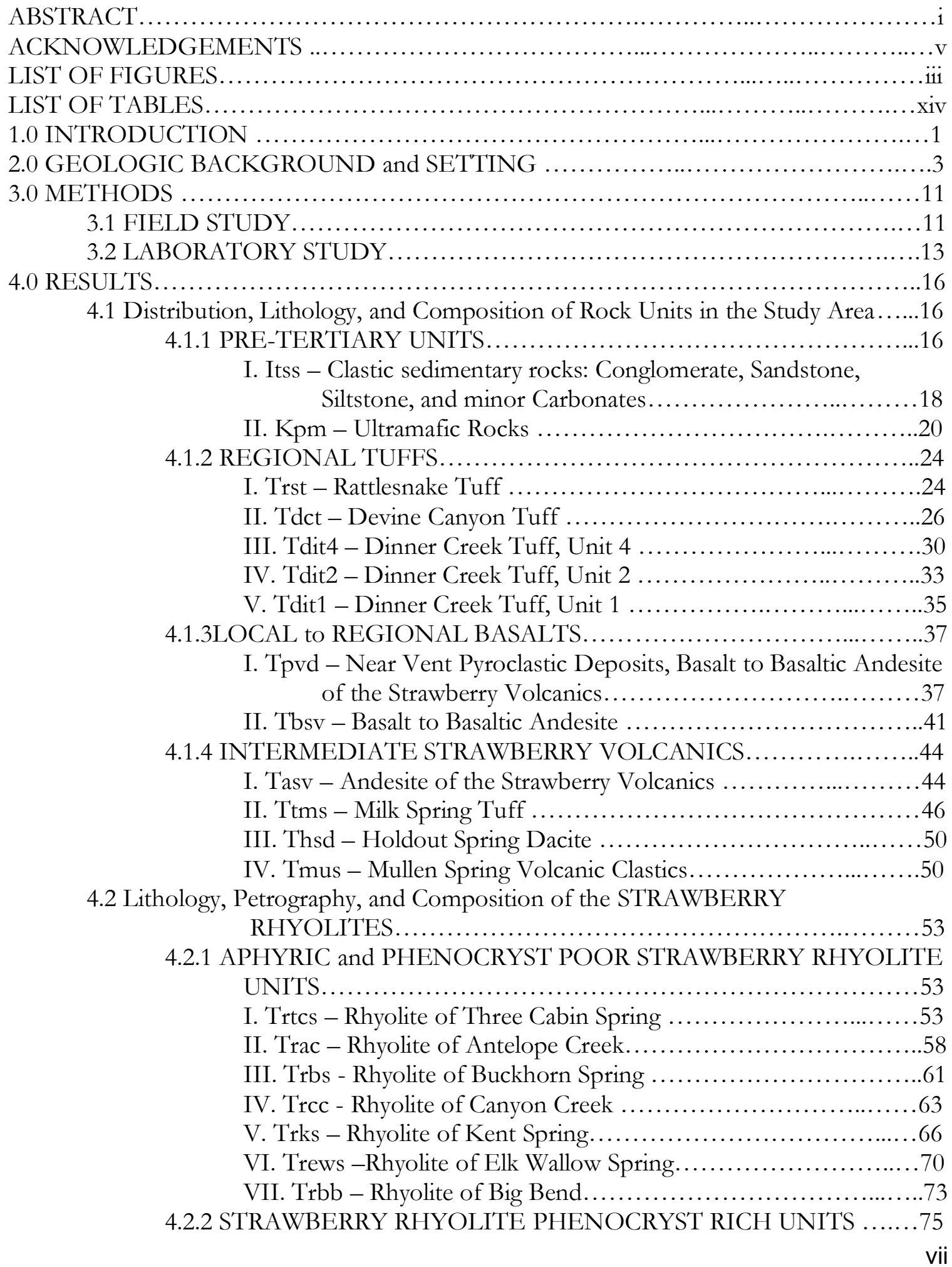


I. Trbc - Rhyolite of Bridge Creek............................ 75

II. Trwm - Rhyolite of Wolf Mountain.........................77

4.3 DISTRIBUTION of RHYOLITES.................................. 80

4.4 AGE of STRAWBERRY RHYOLITES ..................................84

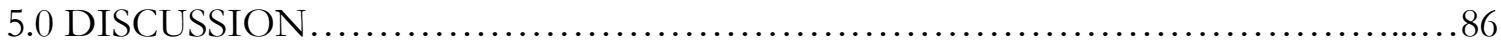

5.1 VOLUME ESTIMATES................................................. 86

5.2 TEMPORAL CHANGES in MINERALOGY and COMPOSITION of RHYOLITES............................................... 89

5.3 COMPARING the STRAWBERRY RHYOLITE FIELD with OTHER MIOCENE and YOUNGER RHYOLITE FLOWS and FIELDS..........95

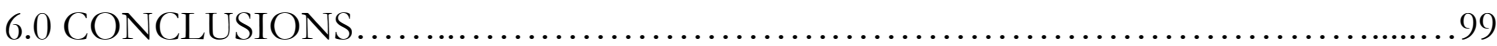

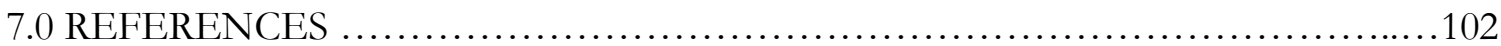

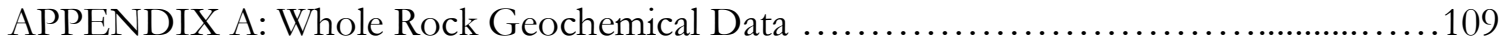

APPENDIX B: Actual Area Sums per Outcrop Mapped .............................166

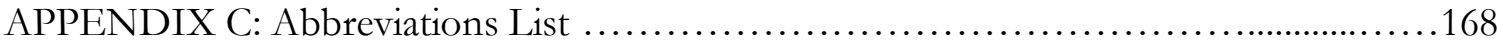

APPENDIX D: Geologic Maps of JOJM \& BC through the EDMAP Projects...........171 


\section{LIST OF FIGURES}

Figure 1: Color-enhanced, shaded relief location map of northern Harney Basin. Basin boundaries and location of quadrangles of interest (black boxes). The red rectangle indicates the region of investigation. The geologic mapping for this project occurred in Jump-off Joe Mountain, Big Canyon, Logan Valley West, and Magpie Table quadrangles. This map was created on ArcMap to show the location of the study area within Oregon. ....................2 Figure 2: Map of Paleozoic and Mesozoic rocks of the Blue Mountain terranes. The red stars indicate the investigation's location-modified from LaMaskin et al. (2008) . ................3 Figure 3: The image on the bottom is the full 1x2 Canyon Mountain geological map (Brown and Thayer, 1966) modified to show the region of study outlined in red and highlighting their unit (Ts) Strawberry Volcanics in red, which is the mapped overarching Miocene unit. The image on the top left is the study area broken into quadrangles and zoomed in to compare to the mapping results of this study. The image on the top right shows this project's combined geology of Jump-off Joe Mountain, Big Canyon, Logan Valley West, and Magpie Table

quadrangles.

Figure 4: The image on the left is a map of the northwestern U.S., showing the approximate locations of Yellowstone hotspot volcanic fields (orange), Columbia River Basalts (gray), with Steens Basalt outlined in light orange. The boundary of Yellowstone National Park is shown in yellow. The purple ellipse represents the High Lava Plains (HLP) of Oregon. The red square indicates the field area of this project. The map is modified from Barry et al. (2013), Smith and Siegel (Windows into the Earth: the geologic story of Yellowstone and Grand Teton National Parks: Oxford University Press, 2000), Christiansen (USGS Professional Paper 729-G, 2001), and Long et al., 2009. The map on the right is an enhanced visual of the field area. The map on the right was produced using ArcMap..................6 Figure 5: Stratigraphy of main-phase Columbia River basalts, modified from Wolff et al. (2008). Column depicts main phase ages which coeval with the Strawberry Mountain Rhyolites. The map was made on ArcMap: Black boxes = this Study area; Blue dot = cities; Light yellow region $=$ Harney Basin; Purple Triangles $=$ dike swarms $(\mathrm{CJ}=$ Chief Joseph 
Swarm; M=Monument swarm feeding Picture Gorge basalts; S= Steen's swarm). The dashed grey ellipse encloses the present-day area where crustal-depth magma champers for the flood lavas are inferred to lie. The red ellipse is the likely source area of the Dinner Creek Tuff eruptive center (Steiner and Streck, 2013; Streck et al., 2015). ...........................8 Figure 6: Field mapping area for this project. Including the quadrangles Big Canyon and Jumpoff Joe Mountain, alongside the western halves of the Logan Valley West and Magpie Table quadrangles. The green box encompasses the area covered in this study. The tan dotted area on the east is the area for which was unmapped in this study. The black dashed lines separate the quadrangle boundaries. The grey hillshade map layer is comprised of all the lidar available for the region- areas without gray do not have lidar data available. ......................10 Figure 7: XRF and ICP-MS geoanalytical process conducted by Chanel Dvorak at Washington State University, Pullman Campus. (A) Rock chips were brought to WSU from PSU in the process of crushing rocks to powders. (B) Round two of crushing rocks into powders at WSU and post addition of dilithium to powdered samples and placed in carbon crucibles. (C) Samples were cooling into beads from being melted in an oven at $1000^{\circ} \mathrm{C}$. Further processes are conducted to generate XRF and ICP-MS data. ....................14 Figure 8: Distribution of the units Itss (tan) and Kpm (brown) across the entire mapping area

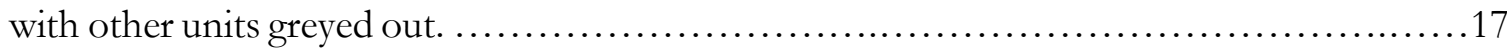

Figure 9: Sandstone of the Accreted Terranes in hand sample. The left image (sample BC19A45) is pictured with some of the unit's quartz veins throughout the sandstone in Big Canyon. The image of the right (BC19A01) has slightly more of a greenish hue. .............18 Figure 10: Thin section images of the Sandstone of the Accreted Terranes. The top row images are all in XPL, whereas the bottom is in PPL. (A) is sample BC19A45, (B) BC19A01, and $(\mathrm{C}) \mathrm{BC19B06.} \mathrm{All} \mathrm{pictured} \mathrm{are} \mathrm{in} \mathrm{100X} \mathrm{optical} \mathrm{zoom.} \mathrm{..........................} 19$

Figure 11: Pictured is the Pretertiary Ultramafics, Sample BC19A07. ...................21 Figure 12: Full thin section image of sample BC19A07, Pretertiary Ultramafic unit. The

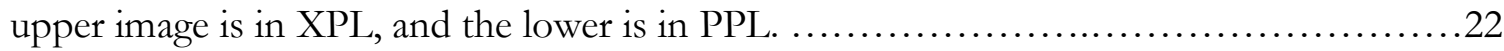
Figure 13: Thin section images of sample BC19A07 all captured in 100X optical zoom. The top row of images is in XPL, and the bottom row is in PPL. ............................ 
Figure 14: Image $B$ and $C$ are examples of typical partially welded vitric hand samples of Rattlesnake Tuff, all from the outcrop in image A. Visible features are light to gray pumice clasts in gray glass shard matrix. Image A (Sample CD1988) is in the southern-central region

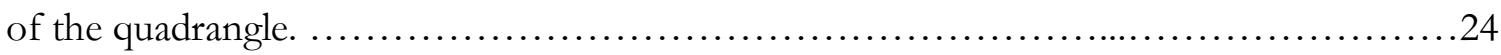

Figure 15: Distribution of the unit Trst (red) across the entire mapping area with other units

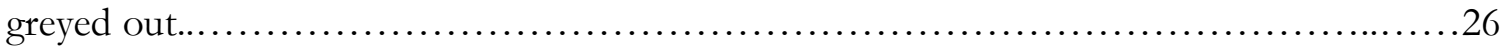

Figure 16: Image $\mathrm{A}$ is an outcrop of Devine Canyon tuff within the Big Canyon quadrangle. The black streaks amongst the outcrop hand samples seen in pictures B and D are fiamme (flattened pumices). Hand samples seen in image $\mathrm{C}$ show the variance in color throughout

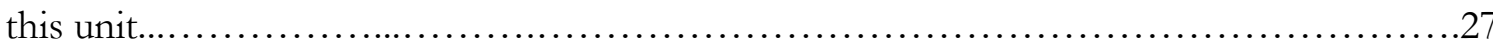

Figure 17: Full slide thin section image of Devine Canyon tuff (sample JJ18B3.1) shown in PPL. Displays glassy (ash) matrix with quartz phenocrysts.

Figure 18: Distribution of the unit Tdct (pink) across the entire mapping area with other units

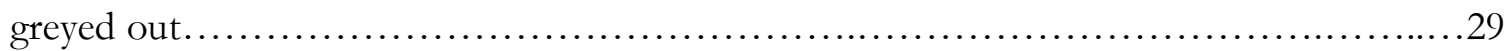

Figure 19: Zr versus $\mathrm{Nb}$ of all regional to local silicic ash-flow tuff units. ..................30 Figure 20: Image (A) sample BC19A26B, (B and C) outcrop and hand sample CD1936A, lastly image (D) sample BC19C40............................................ 31 Figure 21: Image of Tdit4 sample BC19A26B. The left image is in XPL, whereas the right is in PPL, represented in 100X optical zoom. .32 Figure 22: Distribution of the unit Tdit4 (magenta) across the entire mapping area with other units greyed out.

Figure 23: On the left is a hand sample of Dinner Creek Tuff unit 2. The right image shows this unit in an outcrop. 34 Figure 24: Distribution of the unit Tdit2 (peach) across the entire mapping area with other units greyed out. .35 Figure 25: Dinner Creek Tuff unit 1 is found in varying shades of color and alteration, basal vitrophyre, spherulitic tuff, and devitrified. Image A is from sample BC19A61, where B and C are from sample CD1979. 
Figure 26: Thin section image of Dinner Creek unit 1 (sample BC19A61). The images display a glassy (ash) matrix. The left image is in XPL, with the right being in PPL. Images

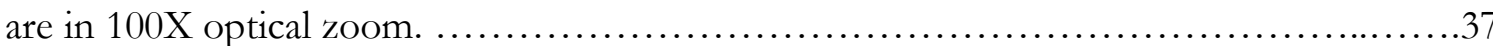

Figure 27: Photograph looking at a sizeable basaltic-andesite outcrop in the BC map's

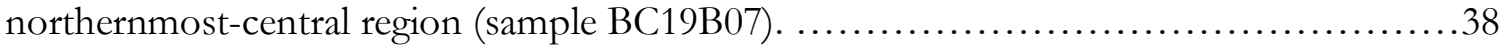

Figure 28: Close-up look at the basaltic andesite outcrop (Sample BC19B07). Highly vesiculated red basaltic andesitic scoria consisting of fine lapilli occasional coarse ash and featuring spindle bombs around and protruding out of the outcrop. .....................38

Figure 29: Distribution of the units Tpvd (light green) and Tbsv (dark green) across the entire mapping area with other units greyed out.

Figure 30: Photograph looking north at mafic pyroclastic flow, unit Tvpd makes up units 1 and $1 \mathrm{~b}$ in the image. Image label unit 2 and scoria fall deposits (unit 3) make up the flow of the pahoehoe toe. "Covered" means talus conceals outcrop; the black line is the upper extent of the talus. "Reworked" means the unit is slightly modified from subsequent processes. The dashed white line is the presumed contact between units. Photograph by Martin Streck. (Ferns, et al., 2017).

Figure 31: (A) Outcrop of Tpvd (named Tbt in JOJM quad) in roadcut along NF17, icelandite juvenile clasts are pictured. (B) Spindle bomb.

Figure 32: Pictured is a full thin section image of sample JJ18A3.1D2. The unit is abbreviated as Tbt in JOJM 7.5 min quadrangle from 2018. This thin section is in PPL and showing a glassy matrix containing lithics and is vesicle rich. .41

Figure 33: Basalt of the Strawberry Volcanics, sample BC19B36 in hand sample.

Figure 34: Basalt of the Strawberry Volcanics, sample BC19B36 in thin section. Image A is in $\mathrm{XPL}, \mathrm{B}$ is in PPL, 40X optical zoom.

Figure 35: Total alkali-silica classification diagram displaying the samples of basaltic to andesitic compositions from this project.

Figure 36: Photograph (A) is an andesite dike (sample BC19B45), with image B representing the dike in hand sample. Image $\mathrm{C}$ is from sample BC19A22 displaying a distinct lithological variant of Tasv that is fine-grained, black, and fractures conchoidally. 
Figure 37: Sample numbers and optical zoom are as follows - (A) BC19A50 (100X), (B) BC19A22 (40X), (C) BC19C69 (40X). The top half of the photograph's thin sections are in XPL, with the bottom half in PPL. .............................................. 45

Figure 38: The first image on the upper left is a finely stratified tuff of Milk Spring consisting of the surge and fallout deposits. The hand in the image measures a section of about $5 \mathrm{~cm}$ thick. The image on the upper right is the outcrop used in the thickness model image found at the bottom of this figure. The bottom image was generated using Google Earth and knowledge of this field location in the JOJM quadrangle. Ttms cropping out in this location measures about $35 \mathrm{~m}$ in thickness. ..........................................47 Figure 39: (A)-(B) Milk Spring Tuff of the south-central region of the Jump-off Joe Mountain quadrangle. The basal surge and fallout deposits are about $1 \mathrm{~m}$ thick and overlain by an ignimbrite incorporating larger lithics. (C) Fallout tuff and surge deposit in a nearby section of the Milk Spring Tuff.

Figure 40: Milk Spring Tuff in hand sample BC19C56 displays lithics made up of multiple units.

Figure 41: Milk Spring Tuff in thin section, XPL on top with PPL images on the bottom. Note prominent lithic fragments in B and C with lithologies of andesites of the Strawberry Volcanics. All images are from sample BC19C56, with A and B in 100X optical zoom. Lastly, with C and D in a 40X optical zoom. .49 Figure 42: Left upper image is of the fine-grained epiclastic debris flow member in outcrop off NF17. The right image is a close-up image of this unit's block and ash flow member, the Mullen Spring Volcanic Clastics. The lower image is the same outcrop but detailing its unit thickness.

Figure 43: Geologic field map highlighting the units Tmus (pale turquoise) and the unit Thsd (purple). These units are superimposed on the entire mapped extent, with most other units greyed out, besides for Tasv and Ttms for context regarding the zoomed-in image.

Figure 44: Outcrop and hand sample images of Three Cabin Spring rhyolite sample CD1977 on the left. With the right image being a Trtcs obsidian member image from the LVW quad. 
Figure 45: Thin section of a sample of devitrified Three Cabin Spring Rhyolite (Sample CD1830), with visible flow banding, in PPL.

Figure 46: Photos are of the Rhyolite of Three Cabin Spring, the left image being from the JOJM quadrangle near Round Mountain where sample CD1875 was collected. The image on the right was generated using Google Earth and knowing where this unit crops out in the study area. This outcrop location is in the MPT quadrangle along the northwestern margin. Trtcs crops out in this location and covers the entire hillside stretching into its neighboring west quad of JOJM. Using this model, Trtcs unit thickness measures about 768m. The large size is in part a result of a fault that runs between these two locations. The fault is northsouth trending and dipping to the east. A typical unit thickness will range from 40$180 \mathrm{~m}$ 55

Figure 47: Ba vs. Sr variation diagram for the Strawberry Rhyolites, highlighting samples of unit Trtcs (red).

Figure 48: $\mathrm{Nb}$ vs. Zr variation diagram for the units found in this study. This plot classifies samples as I-type or A-type using the discrimination techniques of Whalen et al., 1987. The samples that plot outside the box have A-type affinities, and samples with $\mathrm{Zr}$ less than 250 ppm and $\mathrm{Nb}$ less than $20 \mathrm{ppm}$ are classified as I-type. The coordinates of the box are $\mathrm{X}=250, \mathrm{Y}=20$. The undefined unit is regarding a (perlitic) rhyolite sample found in the MPT quadrangle. This has yet been defined as a discrete unit, as this map is still in progress by PSU graduate student Rachel Sweeten. ...........................................56

Figure 49: This figure represents plots A through F (Figure 50 with plots $G$ through J) trace elements vs. $\mathrm{SiO}_{2}$ wt. \% plots for the SV rhyolites. Plot A: Eu/Eu* vs. $\mathrm{SiO} 2$ wt. \%. Plot B: Ba ppm vs. SiO2 wt. \%. Plot C: La ppm vs. SiO2 wt. \%. Plot D: Sr ppm vs. SiO2 wt. \%. Plot E: Rb ppm vs. SiO2 wt. \%. Lastly, Plot F: the ratio $\mathrm{La} / \mathrm{Yb}$ ppm vs. SiO2 wt. \%. ............57 Figure 50: This figure represents $G$ through J plots (see Figure 49 for A through F) trace elements vs. $\mathrm{SiO}_{2}$ wt. \% plots for the SV rhyolites. Plot G: Nb ppm vs. SiO2 wt. \%. Plot H: $(\mathrm{Zr}+\mathrm{Nb}+\mathrm{Y}+\mathrm{Ce})$ ppm vs. SiO2 wt.\%. Plot I: TiO2 wt. \% vs. SiO2 wt. \%. Lastly, Plot J: Zr

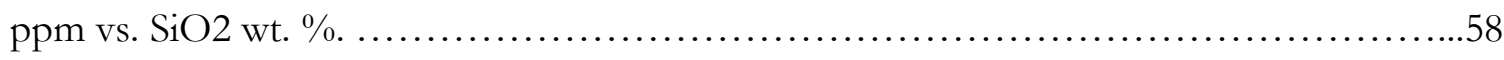

Figure 51: The image on the left is the obsidian member of Antelope Creek Rhyolite, and the right image is devitrified. Photos are from hand sample CD1879 . .....................59 
Figure 52: Photos are from the exact outcrop location in the JOJM quadrangle where sample CD1879 was collected. The image on the left highlights the obsidian member of Trac, and the top of the hill is where its devitrified member is found. The image on the right measures from the top of the outcrop to the road, recording a thickness of $129 \mathrm{~m}$. Just east of this outcrop, an NW trending fault dips to the NE towards this outcrop. The fault could be accounting for some displacement thus thickness, where a typical Trac outcrop thickness ranges from 30 $70 \mathrm{~m}$.

Figure 53: Obsidian of Antelope Creek rhyolite as full thin section image, showing about 4\% phenocrysts, clear quartz and plagioclase, and dark shaded acicular biotite.

Figure 54: Hand samples of rhyolite of Buckhorn Spring unit (A) BC19C30 sample and (B)

BC19C37 sample.

Figure 55: This image representing Trbs highlights this unit's highest peak and most exposed region in the $\mathrm{BC}$ quadrangle. About $1 \mathrm{~km}$ west of this peak, a fault runs north-south for about $7 \mathrm{~km}$ in length, dipping east. This extensional faulting and the youth of the Trbs unit itself would account for its significant cliffside exposures. Trbs typically has a thickness of about $20-120 \mathrm{~m}$.

Figure 56: Images of the Rhyolite of Buckhorn Spring in thin section from sample

BC19C30. The row of images on top is represented in XPL, and the bottom row is in PPL.

Image (A) is in 100X optical zoom, with (B) in 40X optical zoom.

Figure 57: Outcrop of rhyolite of Canyon Creek located in the map's furthest north-eastern corner (sample CD1943). . .64

Figure 58: These images represent the rhyolite of Canyon Creek. This unit is very well exposed as it lies on a fault that runs north-south for about $7 \mathrm{~km}$ in length and dips to the east. The east block, which incorporated the unit Trcc and its outcrop pictured, has also formed a lake in its offset. The top image shows the lake meeting Trcc in outcrop. The bottom right map was generated in Google Earth to measure the unit's exposure. The unit thickness measurement occurred from the south side of the lake to the adjoining peak. Its thickness measures $135 \mathrm{~m}$, which is an accurate high range thickness value for Trcc. 
Figure 59: Thin section images of Canyon Creek rhyolite from float sample BC19A11 with images in XPL on top and PPL at the bottom (A) in 100X optical zoom and (B) in 40X optical zoom.

Figure 60: Kent Spring rhyolite (CD1932). Overall, the unit is crystal poor and distinguishable by the presence of amphibole.

Figure 61: These images represent the rhyolite of Kent Spring and its amount of exposure due to faulting in the region. Both images are from the same outcrop, located in the far SE of the $\mathrm{BC}$ quadrangle. Four north-south trending faults intersect this unit in an east-dipping extensional domino effect, generating considerable exposure. With Trks remaining relatively local to this area, its typical maximum unit thickness is about $200 \mathrm{~m}$. The map image was produced on Google Earth along with geologic mapping knowledge of the region.

Figure 62: Thin section images of Kent Spring rhyolite sample CD1932. The top row of images is in XPL, and the bottom row is in PPL. Image (A) is in 40X optical zoom, whereas (B) is in 100X optical zoom, shown crystal poor nature with about 1\% amphibole crystals.

Figure 63: Ba vs. Zr variation diagram for the Strawberry Rhyolites, highlighting samples of unit Trks (red). The unit Trks has a distinctly lower Zr ppm than the other SR units. Figure 64: The image is of the Rhyolite of Elk Wallow Spring, where the highest elevation is atop Glass Mountain in MPT and is the sample location for RS20MPT03. The map image was generated using Google Earth and used knowledge of where this unit crops out in the study area. Trews crops out in this location and covers this entire, overall wedged between Trtcs and Trac. Using this model, Trews unit thickness measures about 488m. The measurement of the unit may have a deviation as many faults that trend north-south just to the east of this location, crossing into neighboring quads of JOJM and BC. The faults are dipping to the east, generating domino extensional features. A typical unit thickness will range from $40-200 \mathrm{~m}$, making sense for this unit's location in the study area. ..............70 Figure 65: Hand sample of the rhyolite of Elk Wallow Spring. This sample is from the top of Glass Mountain in the Magpie Table quadrangle (RS20MPT03) 
Figure 66: Petrographic thin section of Trews from the MPT quadrangle. Flow banded, with prominent acicular phenocrysts of hornblende and plagioclase phenocrysts in a glassy, flow

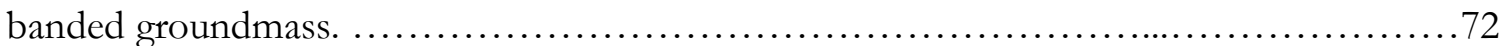

Figure 67: Zr vs. Sr variation diagram for the Strawberry Rhyolites, highlighting unit Trews (green) and Trbc (red) samples. The unit Trews and Trbc are lithologically similar but can be differentiated by their trace elements. Specifically, $\mathrm{Zr}$ and Sr, where the unit Trews has an overall lower $\mathrm{Zr}$ and Sr trace element concentration than the unit Trbc. .72 Figure 68: The image on the left is a typical outcrop of Trbb. The image on the right is a

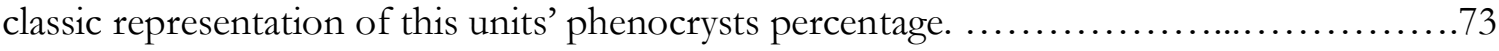
Figure 69: Image is of the Rhyolite of Big Bend; the map image was generated using Google Earth and by using knowledge of where this unit crops out in the study area. Trbb crops out in this location and overall only in a small portion throughout the entire map, $\sim 1 \mathrm{~km}^{2}$. Using this model, Trbb unit thickness measures about $1,039 \mathrm{~m}$ at maximum. This area is in close proximity to Bear Creek. Large alluvium-filled meadow and creek. Directly to the west, in the quadrangle $\mathrm{BC}$, there are a couple of outlier faults that trend from east to south, where all other faults in the region tend to be normal faults. I suspect that this potentially active faulting is the cause of this rather large unit thickness. Especially regarding Trbb is one of the younger, if not youngest SR unit.

Figure 70: Thin section image of unit Trbb in XPL from sample LVW-N-19. The thin section image features a very fine-grained matrix encompassing glomerocrysts.

Figure 71: (A) Hand sample of Trbc, devitrified with amphibole and biotite, clearly visible. (B) Vitric hand sample of Trbc, outcrop just south of Che Spring in JOJM. (C) A smaller outcrop of the Bridge Creek Rhyolite is consistently found amongst a sizeable blocky and more extensive outcrop. ......................................................... 75

Figure 72: Thin section of the Rhyolite of Bridge Creek. Full slide images, the left is in PPL, and the right image is in XPL, from sample JJ18A257. The thin section highlights the abundance of clearly visible biotite and amphibole crystals, making up about 3\%, with about $8 \%$ plagioclase. . .76

Figure 73: Photos are of the Rhyolite of Bridge Creek (formerly known as the unit Tsvr in the 2019 JOJM map). The left image is from the JOJM quadrangle, NW of Bond Spring. 
The image on the right was generated using Google Earth and subsequent knowledge of this unit within the study area. The majority of Trbc crops out in this location covering the entire hill, continuously reaching the NE and SW, covering a stretch of $\sim 7 \mathrm{~km}$. Using this model and a prominent location of a continuous outcrop of Trbc, its unit thickness measures about $785 \mathrm{~m}$. The sizeable unit thickness estimate is likely due to the extensional faulting throughout the region, exposing a substantial face of Trbc. Thus, a typical unit thickness will

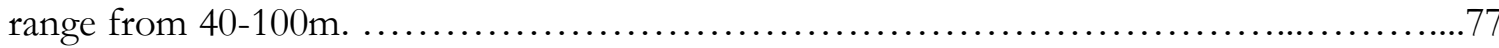
Figure 74: Wolf Mountain rhyolite in outcrop and as hand sample (CD1921)............78 Figure 75: Wolf Mountain rhyolite in hand sample. From (A) to (C), the samples go from non-glassy to glassy. Each variety is of the 30\% phenocryst-rich variety found in the Jumpoff Joe Mountain quadrangle. .78

Figure 76: Photos are all from the Rhyolite of Wolf Mountain and are indeed from the south-eastern side of Wolf Mountain in the JOJM quadrangle. The image on the right was generated using Google Earth using knowledge of this unit in the study area. The majority of Trwm crops out to the South in JOJM and the east in MPT quads. By using this model, the unit Trwm thickness measures about $940 \mathrm{~m}$. The sizeable, estimated thickness is partly due to the north-south trending fault that dips east and runs directly through this section. In addition, the exposed Trwm is exceptional due to the extensional faulting, exposing a prominent face of Trbc. A typical unit outcrop thickness, however, remains rather large, ranging from $50-200 \mathrm{~m}$. .79 Figure 77: Thin section images from sample CD1964. The top row exhibits XPL, while the bottom row is in PPL. Image (A) is in 40X optical zoom, with (B) in 100X optical zoom....80 Figure 78: This study's estimated original coverage of each Strawberry rhyolite unit (in color) superimposed on the mapped extent (black).

Figure 79: Geologic map showing rhyolite outcrops in dark gray and estimated original coverage of all rhyolite units of this study (in color). Dvorak conducted the mapping of the quadrangles Big Canyon and Jump-off Joe Mountain, and current PSU graduate student Rachel Sweeten mapped the Logan Valley West and Magpie Table quadrangles...............83 Figure 80: Plot (A) is a variation diagram for $\mathrm{Eu} / \mathrm{Eu}^{*}$ vs. $\mathrm{SiO} 2$ wt.\% for the Strawberry Rhyolites, highlighting the trend of as silica increases the compatible element (Eu) decrease. 
Plot (B) is also a variation diagram, highlighting the trace element Ba versus silica content. Circled in red, most of the units have a high $\mathrm{Ba}$ value (exception of Trks). This high concentration indicates how compatible they are-the higher the $\mathrm{Ba}$, the stronger the compatibility in alkali feldspar.

Figure 81: Estimated volume versus age plot of the Strawberry Rhyolites. This plot highlights how as the rhyolite units go from older to younger, they also trend towards larger to smaller regarding volume in size. The larger bold numbers on the plot are the age dates acquired, with the smaller numbers being their estimated volume. The map images below the graph highlight each specific unit's estimated area based on maps produced in the field area. Figure 82: Map image incorporates all the rhyolite units or units with a rhyolite component (Ttms)) mapped in this project; all units that are not locally sourced rhyolites are greyed out. This map shows that the presence of rhyolite is more varied and extensive than previously

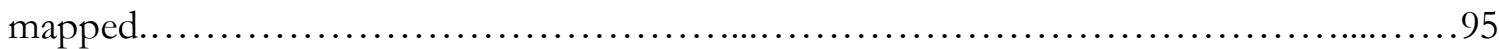
Figure 83: Figure representing a size comparison to the project area and other rhyolite fields. Each volcanic field is on the same scale to highlight its size differences. ...................98 Figure 84: Geologic map produced through this study incorporates the geology of Jump-off Joe Mountain, Big Canyon, Logan Valley West, and Magpie Table quadrangles, depicting how various the area's units genuinely are. 101 


\section{LIST OF TABLES}

Table 1: Calculated distribution area, from largest to smallest of Strawberry rhyolitic units. The area in this table is based on the estimated size of each unit (Figure 78) and the geometry of the polygons generated in ArcMap from the final map produced from fieldwork

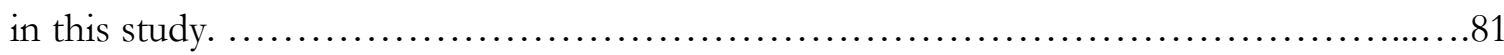

Table 2: This area and volume table is produced by compiling all the field mappings of each Strawberry rhyolite unit, generating an estimated area polygon surrounding all those units, and calculating its overall geometry in ArcMap; the area is outlined in red. Then using this geometry with field compiled data, an estimated volume is produced..............................84 Table 3: Compilation of ${ }^{40} \mathrm{Ar} /{ }^{39} \mathrm{Ar}$ age dates of SR units found in this project mapped region. Unit abbreviations are elaborated by unit names in Table 1, or the legend of the project map found in the appendix.

Table 4: The Strawberry Rhyolite units are listed according to age, from oldest to youngest. Unit abbreviations are elaborated by unit names in Table 1, or the legend of the project map

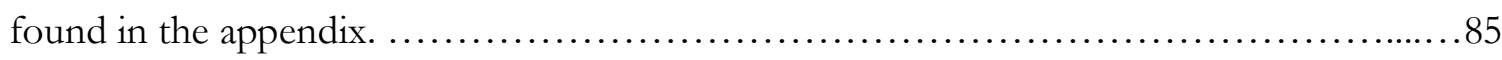

Table 5: Calculated volume of Strawberry rhyolitic units, from largest to smallest. The volumes are calculated using each unit thickness multiplied by their respective area....

Table 6: Calculated volumes of each rhyolite unit based on the estimated area (see Table 1) and their respective unit maximum and minimum thicknesses that were discerned from fieldwork component and observations from well-preserved rhyolite lavas. 


\subsection{INTRODUCTION}

In eastern Oregon, abundant mid-Miocene silicic volcanic rocks crop out amongst voluminous flood basalt flows of the Columbia River Basalt Group (CRBG). One large rhyolite center found within this large igneous province is located south of the Strawberry Mountain range and is part of the Strawberry Volcanics (Figure 1). Only recent work (Steiner \& Streck, 2014) and mapping efforts, including those of this study in the NE part of the Harney Basin north of Burns, have shed light on the existence of a diverse set of volcanic units previously lumped into broad single mapping units by earlier regional reconnaissance maps (Brown and Thayer, 1966). This mapping brought to light the existence of Oligocene dacites with lesser andesites and basalts, mid-Miocene rhyolite, and outcrops of regional tuff units such as the Dinner Creek Tuff that were previously unknown to occur in the area. Hence, there is a much better understanding of the geologic history of the entire northeast margin of the Harney Basin, which plays a significant role in the regional volcanic framework due to this mapping. This region was mapped originally in reconnaissance in the 1960s, where geologic units were poorly delineated, often blanketing whole quadrangles as nearly one unit. For example, more than $90 \%$ of the 7.5 min Jump-off Joe Mountain quadrangle is mapped as 'Ts' - Strawberry Volcanics - and the adjacent Big Canyon quadrangle is similarly nonspecific. In 2018 and 2019, I mapped portions of the area where mid-Miocene rhyolites are exposed as part of two USGS Edmap projects, and my MS thesis project is based on this mapping. When I started this project, prior PSU thesis work by A. Steiner (2016) had broadly revealed the existence of a major rhyolite field in size comparable to the Coso rhyolites of Inyo County, California that covered about $316 \mathrm{~km}^{2}$. Steiner found rhyolite outcrops distributed over four 7.5-minute quadrangles. The work by Steiner also showed rhyolites are comprised of varying 
lithological units and defined a preliminary eruptive age range from 16.2 to $14.3 \mathrm{Ma}$. These rhyolites are part of the Strawberry Volcanics, hereafter referred to as Strawberry Rhyolites (SR). This project builds on Steiner's work. The main focus is to detail the distribution of rhyolite units used for volume estimates, determine the composition and petrography, and obtain additional age dates to better constrain the eruptive history.
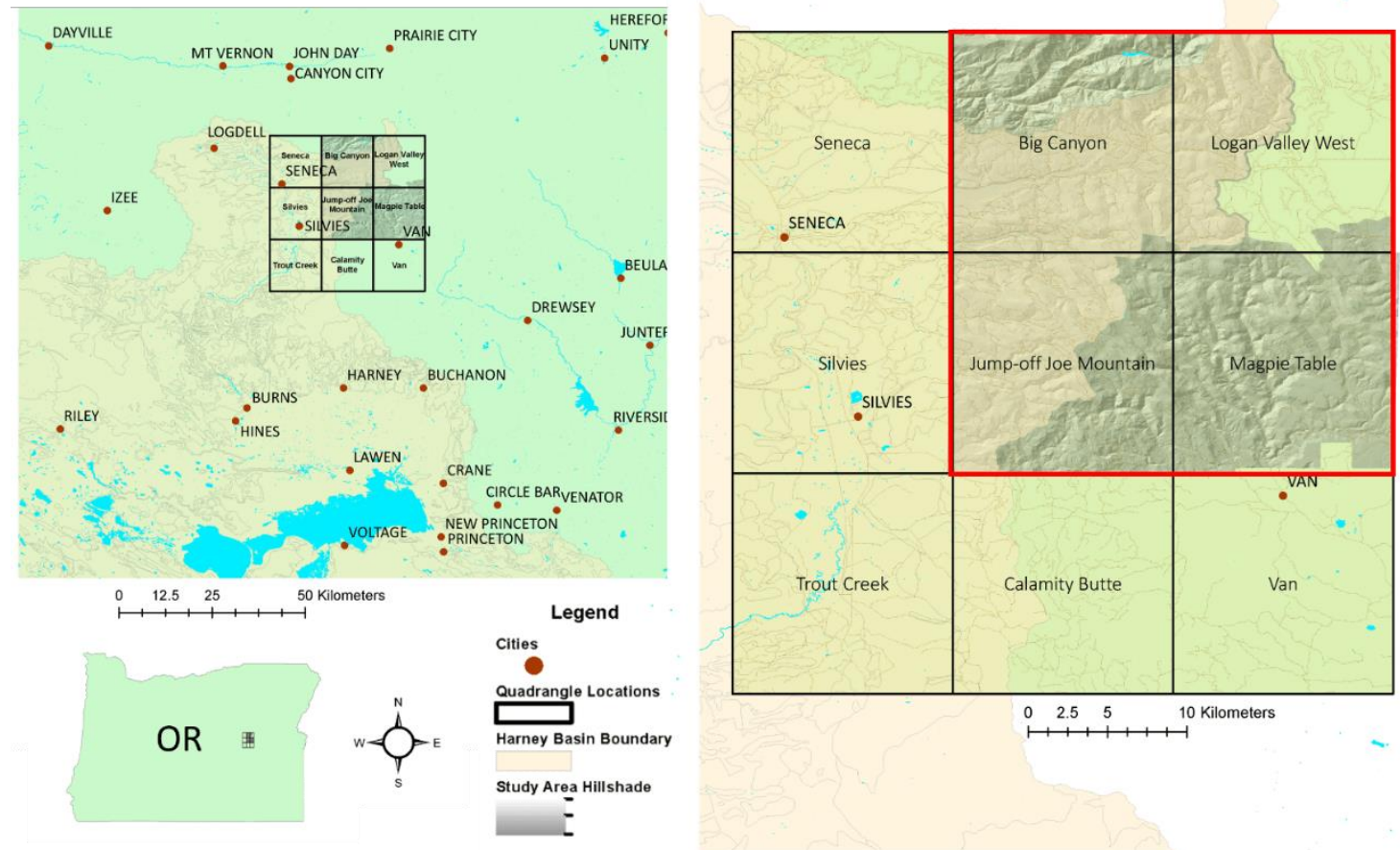

Figure 1: Color-enhanced, shaded relief location map of northern Harney Basin. Basin boundaries and location of quadrangles of interest (black boxes). The red rectangle indicates the region of investigation. The geologic mapping for this project occurred in Jump-off Joe Mountain, Big Canyon, Logan Valley West, and Magpie Table quadrangles. This map was created on ArcMap to show the location of the study area within Oregon. 


\subsection{GEOLOGICAL BACKGROUND and SETTING}

The area of interest consists of four 7.5 min quadrangles: Jump-off Joe Mountain, Big Canyon, Magpie Table, and Logan Valley West, all located along the north-eastern margin of the Harney Basin in eastern Oregon and lie within the Malheur National Forest (Figure 1). The basement rocks of the region consist of accreted island arcs and oceanic crust collectively known as "accreted terranes" (Figure 2).

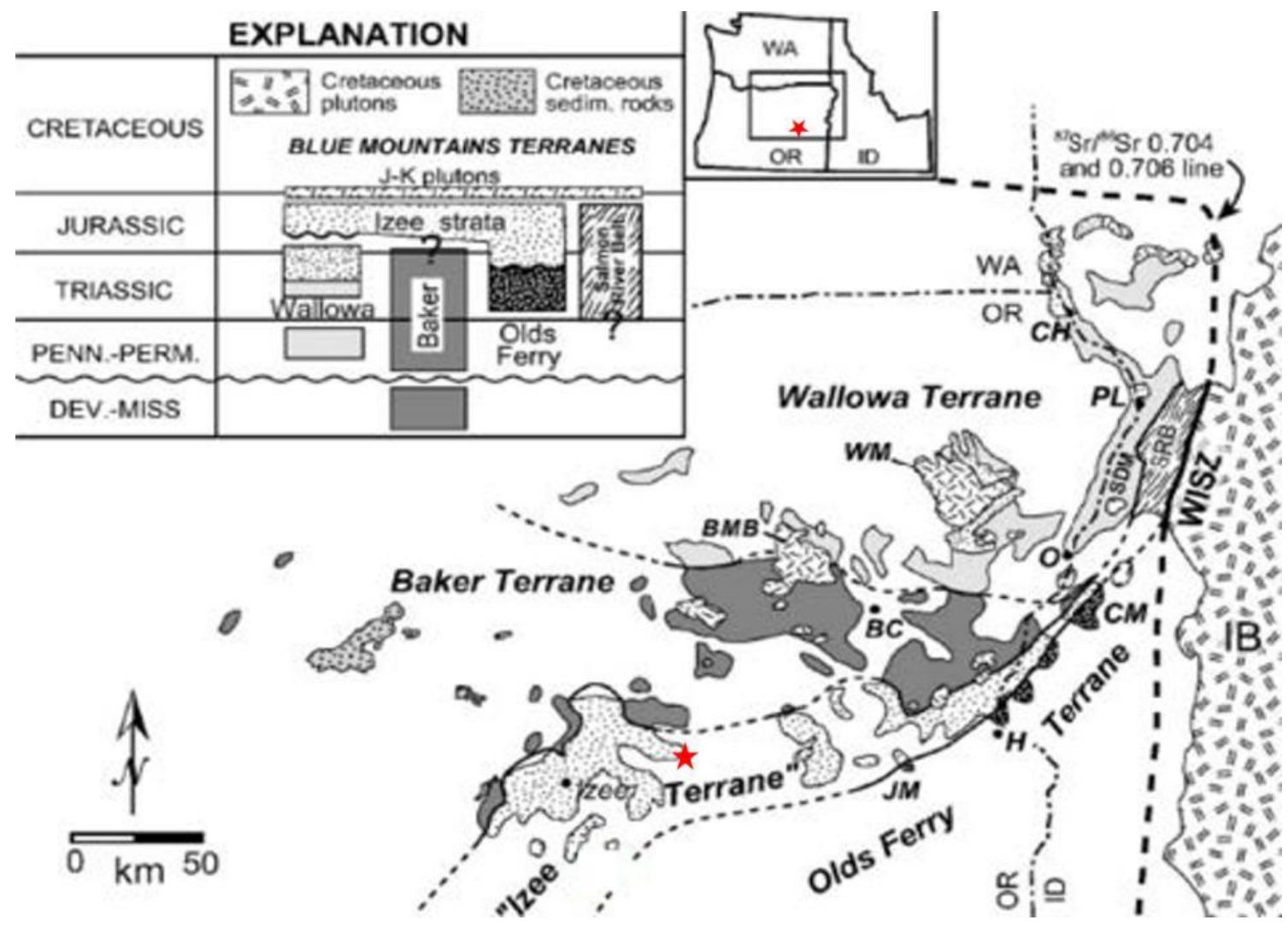

Figure 2: Map of Paleozoic and Mesozoic rocks of the Blue Mountain terranes. The red stars indicate the investigation's location-modified from LaMaskin et al. (2008).

These terranes were accreted from east to west on the North American continent from the late Permian to the Early Cretaceous (Dickinson, 1979; Vallier, 1995; Dorsey and 
LaMaskin, 2008; Schwartz et al., 2010). The quadrangles lie within the Izee basin, a forearc basin where roughly 7,000 meters of marine sediments were deposited from early to middle Jurassic and uplifted in the early Cretaceous due to continued accretion of the Blue Mountain terranes (Dorsey and LaMaskin, 20011; Ware, 2013). On Brown and Thayer's 1x2-degree Canyon Mountain quadrangle (1966), nearly the entire study area was mapped as one Miocene unit, 'Ts' - Strawberry Volcanics (Figure 3), with a small sections 'Jtl' - Jurassic sedimentary rocks.

The name "Strawberry Volcanics" was given to the diverse group of volcanic rocks that overlie Paleogene and pre-Tertiary basement rocks over an area of 3,600 $\mathrm{km}^{2}$ along the southern and eastern margins of the John Day Valley (Thayer, 1957; Brown and Thayer, 1967). Robyn (1979) determined that the Strawberry Volcanics were generally younger than the main phase of the Columbia River Basalt and are calc-alkaline. It was later found that basaltic to andesitic rocks of the Strawberry Volcanics are predominantly calc-alkaline suite but include a mildly tholeiitic suite much smaller in volume (Steiner, 2013a, 2015). The Strawberry Volcanics also includes rhyolite and minor dacite. Other than $\mathrm{FeO}^{*}$, the calc-alkaline and tholeiitic basalts and basaltic andesites (<55 wt. percent $\mathrm{SiO} 2)$ are almost geochemically indistinguishable. Rare basalts resemble the lavas of the Steens Basalt (Steiner and Streck, 2018). Faulting was likely instrumental in forming numerous north-south trending valleys that dot this part of the Blue Mountains province. Quaternary fluvial processes incised canyons and caused several deepseated landslides, resulting in this part of the Strawberry Mountains' present topography. 


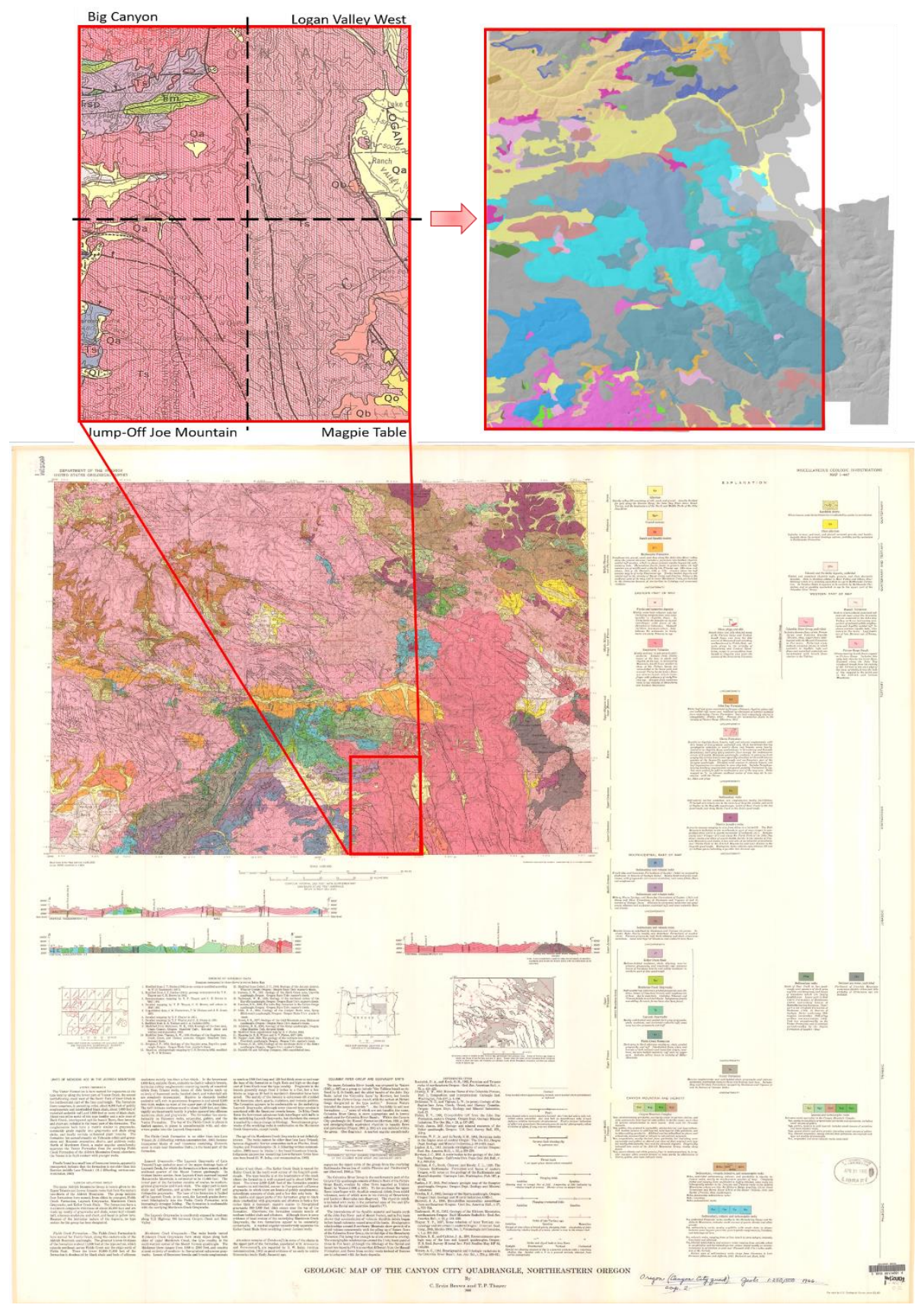

Figure 3: The image on the bottom is the full 1x2 degree Canyon Mountain geological map (Brown and Thayer, 1966) modified to show the region of study outlined in red and highlighting their unit (Ts) Strawberry Volcanics in red, which is the mapped dominant Miocene unit. The image on the top left is the study area broken into quadrangles and zoomed in to compare to the mapping results of this study. The image on the top right shows this project's combined geology of Jump-off Joe Mountain, Big Canyon, Logan Valley West, and Magpie Table quadrangles. 


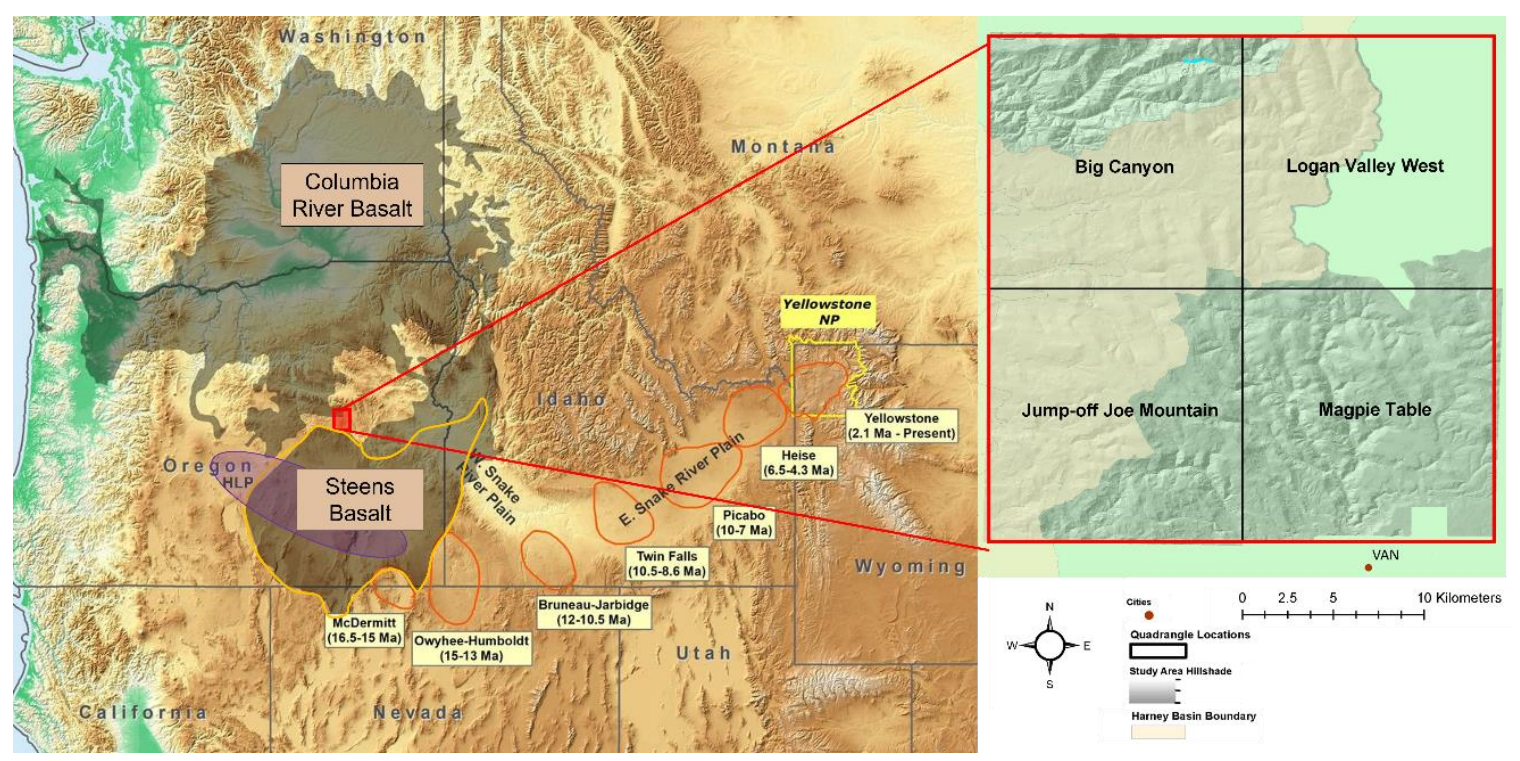

Figure 4: The image on the left is a map of the northwestern U.S., showing the approximate locations of Yellowstone hotspot volcanic fields (orange), Columbia River Basalts (gray), with Steens Basalt outlined in light orange. The boundary of Yellowstone National Park is shown in yellow. The purple ellipse represents the High Lava Plains (HLP) of Oregon. The red square indicates the field area of this project. The map is modified from Barry et al. (2013), Smith and Siegel (Windows into the Earth: the geologic story of Yellowstone and Grand Teton National Parks: Oxford University Press, 2000), Christiansen (USGS Professional Paper 729-G, 2001), and Long et al., 2009. The map on the right is an enhanced visual of the field area. The map on the right was produced using ArcMap.

A late Miocene and younger bimodal volcanic group, expressed as basaltic lava flows, rhyolite domes, and ignimbrites, are exposed along the High Lava Plains (e.g., Ford et al., 2013). Along the High Lava Plains, about 60 rhyolitic dome complexes are lined up in a northwestern direction (Ford et al., 2013). These dome complexes can be monogenetic or long-lived and more complex in size. The rhyolitic domes show an age progression from the oldest ( $12 \mathrm{Ma})$ in the east and becoming progressively younger to the northwest, with the youngest eruptions being at the Newberry volcano $(<1 \mathrm{Ma})$. This age progression mirrors the Yellowstone Hotspot track, with younging from the southwest to the northeast (Coble and 
Mahood, 2016). In addition, three extensive $\left(\sim 100-300 \mathrm{~km}^{3}\right)$ ash-flow tuffs erupted from $\sim 10$ - 7 Ma. From oldest to youngest, these are the Devine Canyon Tuff (9.7 Ma), Prater Creek Tuff (8.5 Ma), and Rattlesnake Tuff (7.1 Ma) (Greene, 1973; Streck \& Grunder, 1997; Ford et al., 2013). Not included within this trend but found in the mapping area is the Dinner Creek Tuff, ranging from 16.1 to $15 \mathrm{Ma}$ (Streck et al., 2015; Isom, 2017). The regional map depicted in Figure 4 highlights the study area amongst the High Lava Plains, the Columbia River Basalts, the Steens Basalts, and the Snake River Plain hotspot track.

Two significant phases characterize the older volcanism within eastern Oregon. The Clarno Formation (54-40 Ma), which is hypothesized to underly the High Lava Plains, crops out extensively to the north and west of the province within the Blue Mountains Terrane (Walker and Robinson., 1990) and the younger John Day formation (38.5-20 Ma) also crops out extensively to the north of the HLP (Bestland and Rettalack., 1994a \&1994b) (Figure 5). Mid-Miocene lavas of the Columbia River Basalt Group overlie the Blue Mountain Terrane basement rocks and the earlier Cenozoic volcanic rocks across central and eastern Oregon and consist mostly of tholeiitic flood basalts that erupted from various dike swarms, and volcanic centers across eastern Oregon, northern Nevada, southern Washington, and western Idaho from 16.8 - 5 Ma (Swanson et al., 1979; Hooper, 1997; Hooper et al., 2002; Camp \& Ross, 2004; Camp \& Hanan, 2008; Wolf \& Ramos, 2013; Coble \& Mahood, 2012; Reidel et al., 2013). 


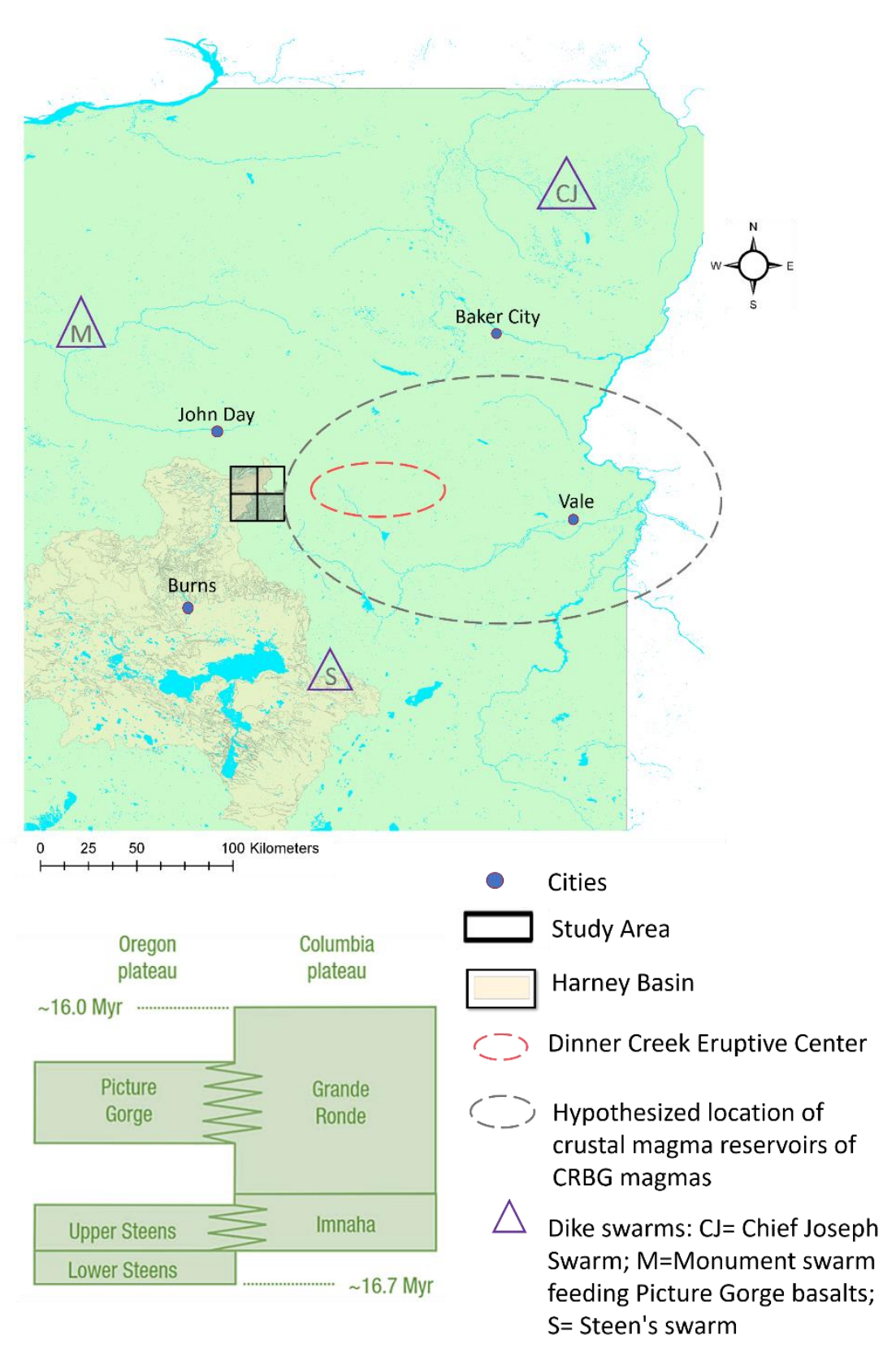

Figure 5: Stratigraphy of main-phase Columbia River Basalt units, modified from Wolff et al. (2008). The column depicts main phase units and overlaps with the other ages of the Strawberry Mountain Rhyolites. The map was made on ArcMap: Black boxes = this Study area; Blue dot = cities; Light yellow region = Harney Basin; Purple Triangles = dike swarms $(\mathrm{CJ}=$ Chief Joseph Swarm; M=Monument swarm feeding Picture Gorge basalts; $\mathrm{S}=$ Steen's swarm). The dashed grey ellipse encloses the present-day area where crustal-depth magma champers for the flood lavas are inferred to lie. The red ellipse is the likely source area of the Dinner Creek Tuff eruptive center (Steiner and Streck, 2013; Streck et al., 2015). 
Based on the age range of 16.16 to 14.37 Ma from Steiner and Streck, 2013, and ages compiled from this study, the Strawberry rhyolites belong to the relatively recently recognized rhyolite flare-up associated with the main pulse of volcanism of the CRBG (e.g., Coble and Mahood, 2012; Streck et al., 2015). Early eruptions of rhyolites in the southern part of the Strawberry Volcanics are coeval with the CRBG magmatism of the Grande Ronde Basalt. Other Co-CRBG silicic volcanism includes numerous rhyolitic ash-flow tuff that erupted from various volcanic centers across eastern Oregon and northern Nevada (Rytuba \& Vander Meulen, 1991; Streck et al., 2015; Benson \& Mahood, 2016; Coble \& Mahood, 2016; Henry et al., 2017; Cruz, 2017). The nearest known volcanic center to the study area is the Dinner Creek Tuff eruptive center. This center lies north of the town of Juntura near the Malheur Gorge between Castle Rock and Ironside Mountain (Streck et al., 2015), where four rhyolitic-dacitic ash-flow tuffs, collectively known as Dinner Creek Tuff units $1-4$ (Tdit1 - 4), erupted from calderas 16 - 15 Ma (Haddock, 1967; Woods, 1976; Streck et al., 2015; Cruz, 2017). All Dinner Creek Tuff units reach into the investigated area and are found primarily in the Big Canyon and Jump-off Joe Mountain, Calamity Butte quads (Figure 6). 


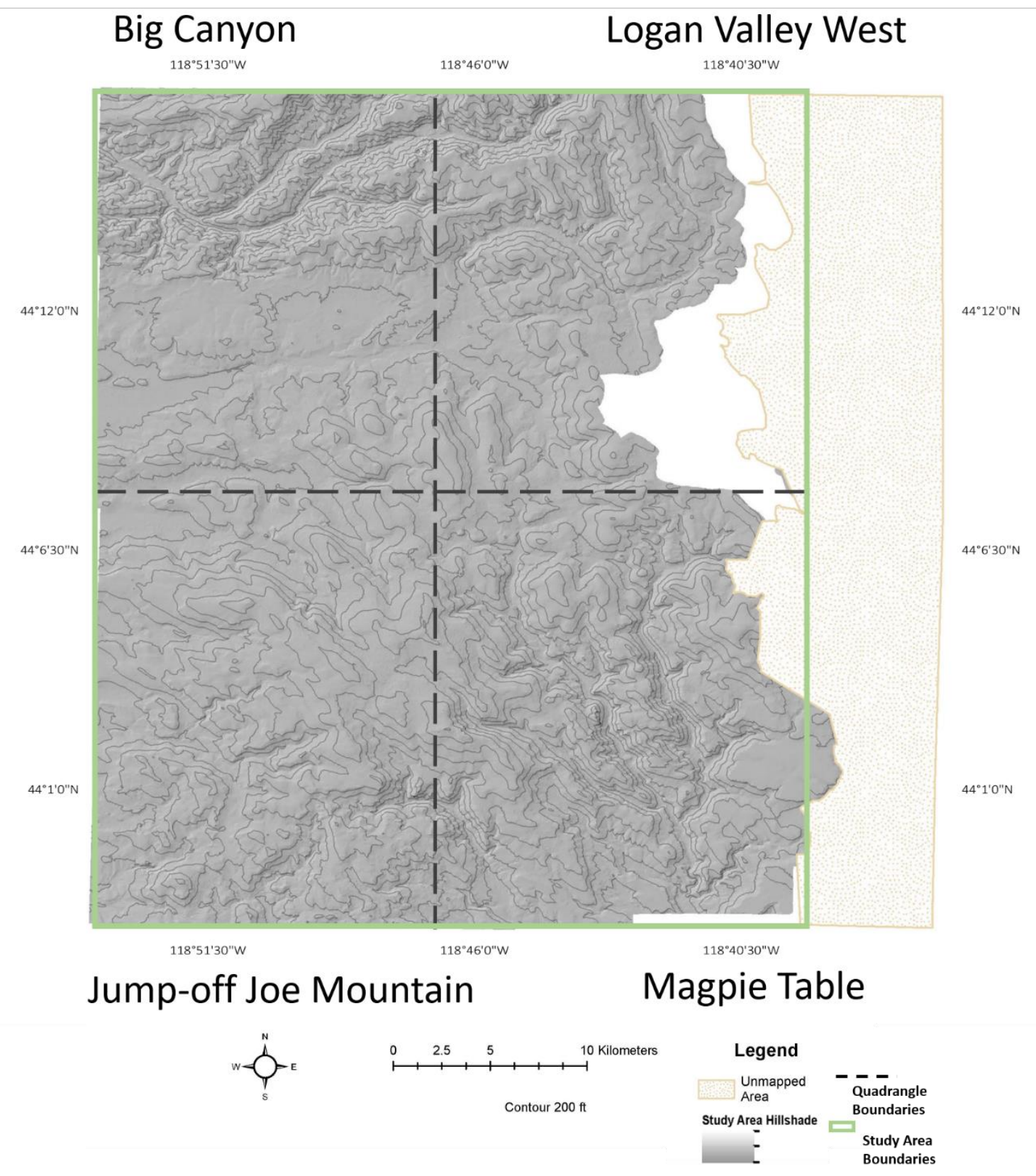

Figure 6: Field mapping area outlined for this project. Including the quadrangles Big Canyon and Jump-off Joe Mountain, alongside the western halves of the Logan Valley West and Magpie Table quadrangles. The green box encompasses the area covered in this study. The tan dotted area on the east is the area for which was unmapped in this study. The black dashed lines separate the quadrangle boundaries. The grey hillshade map layer is comprised of all the lidar available for the region- areas without gray do not have lidar data available. 


\subsection{METHODS}

\subsection{FIELD STUDIES}

Fieldwork for this study was imperative for achieving the objectives. Some fieldwork predated my entering the MS program at PSU with mapping a portion of Jump-off Joe Mountain quadrangle (JOJM) as part of Portland State's field camp in the summer of 2017. This was followed by receiving a USGS EDMAP grant to continue and finish mapping the Jump-off Joe Mountain quadrangle in the summer of 2018. Results from this EDMAP project prompted me to continue this work as my MS graduate thesis project, which was supported by a second USGS EDMAP grant for the Big Canyon quadrangle $(\mathrm{BC})$. The mapping for Big Canyon was conducted in the summer of 2019, aided by field camp participants of this year. Results from the Big Canyon and Jump-off Joe Mountain quads, along with reconnaissance mapping results by Steiner (2016), suggested that rhyolites extend eastward to about half of the adjacent quads.

The primary access roads to the quads lie east of US Route 395 and are forest roads NF17, NF-16, and NF-15. In addition, there are graded gravel roads that run throughout the quads from the national forest roads, with numerous minor dirt roads providing access to much of the mapping areas. The entire map areas were covered by road access, and walking transects were strategically placed throughout the quads. A 7.5 min quadrangle map of Big Canyon, Jump-off Joe Mountain, and eastern neighboring quads were utilized in the field using the GPS mapping software "Avenza Maps." Rocks of outcrops or pieces of float were lithologically classified and logged on the topo map, and a subset was sampled for later analysis. A waypoint location of the field stops was recorded using GPS capabilities on a field tablet 
using the Avenza Maps software. The locations of the samples were recorded using handheld GPS units and the application Avenza Maps then later exported to ArcMap.

Notes and descriptions were entered in field notebooks as well as photos were taken. Samples were taken primarily at outcrop locations, but it should be noted that some samples were taken from large pieces of float due to some areas having poor or no outcrop exposures. The fieldwork portion of this project was accomplished over a total duration of 16 weeks, split across smaller time segments during the summer of 2017, 2018, 2019, and 2020. Since the EDMAP program only allows two projects to be conducted by the same student, the EDMAP project of Summer 2020 to map portions of Logan Valley West (LVW) and Magpie Table (MPT) quadrangles to the east of JOJM and BC required engagement of another student. Hence, mapping in the Logan Valley West and Magpie quadrangle in 2020 was primarily conducted by Rachel Sweeten (current PSU graduate student) and assisted by Dvorak and other PSU students from the PSU field camp 2020. The EDMAP projects resulted in a geological map of the 7.5 min Jump off Joe Mountain and the 7.5 min Big Canyon quad and a geological map of half of the 7.5 min Logan Valley West and Magpie Table quads, which are still in progress.

I used to distinguish one rhyolite unit from another based on what I learned from the PSU's field camp, being a field assistant to other graduate students, and from my own experience. It is an interactive process that builds on lithological and stratigraphic field observations, followed by analytical data consisting of petrographic, geochemical, and sometimes radiometrically obtained age information. In gathering all the information, one needs to be incredibly organized with all your data (notes, computer files, photos) and allow for the process to take a proper allotment of time. For example, each USGS Edmap map I 
produced is a year-long project. The time and process it takes to differentiate units go in stages, with many changes along the way. Initially, it is getting yourself familiar with any known units in and around the area. Determining what distinguishes them from one another and keep thorough notes that are field accessible. Following that is to complete a portion of the field work.

With this initial phase complete, observing rocks in the field leads to a rough schematic of different features that later on are refined after more outcrops have been observed. Each period between field sessions is filled with reviewing samples, specifically the ability to see many of them side by side and use equipment such as binoculars to get a more detailed look. This is also the time to decide which samples are deemed representative of a unit, including consideration of preservation quality prepared for further analysis such as, preparing billets for thin sections and geochemical analysis. With each field session, more details become available, and the process of choosing samples continues. Upon final return from the field again (may be the second or third time), the final decision on important and geologically significant samples is being made. Once analytical data becomes available ( $\sim 3-6$ months), you can start making more solid decisions on which units differ based on their chemical differences and petrographic characteristics. All data feeds into distinguishing the units.

\subsection{LABORATORY STUDIES}

Seventeen rock samples in 2018, twenty-five in 2019, and twenty in 2020 were analyzed at the Geoanalytical Lab at Washington State University, Pullman Campus. Major and trace element data were acquired using the $\mathrm{X}$-ray fluorescence spectrometer (XRF) and the inductively coupled plasma mass spectrometry (ICP-MS). Data were used to determine their 
composition and to differentiate the geologic units. Bulk chemical data are included in the appendix. The sample preparation for the analysis went as follows. First, rock samples were crushed into chips using the rock crusher at Portland State University. At WSU, the chips were crushed into a powder in a tungsten carbide swing mill (mill material is low Ta, Nb steel avoiding contamination of these elements). The powder was then combined with dilithium tetraborate (Li2B4O7) in a ratio of 2:1, dilithium tetraborate to sample. The sample was then fused into a bead in an oven at a temperature of $1000^{\circ} \mathrm{C}$. The beads were re-grinded into powder, and 1 gram of powder was separated to make the ICP-MS bead. Two beads per sample were then made at $1000^{\circ} \mathrm{C}$, one for XRF and one for ICP-MS analysis. The XRF bead was analyzed in the XRF machine, and the ICP-MS bead was dissolved for the final analysis.

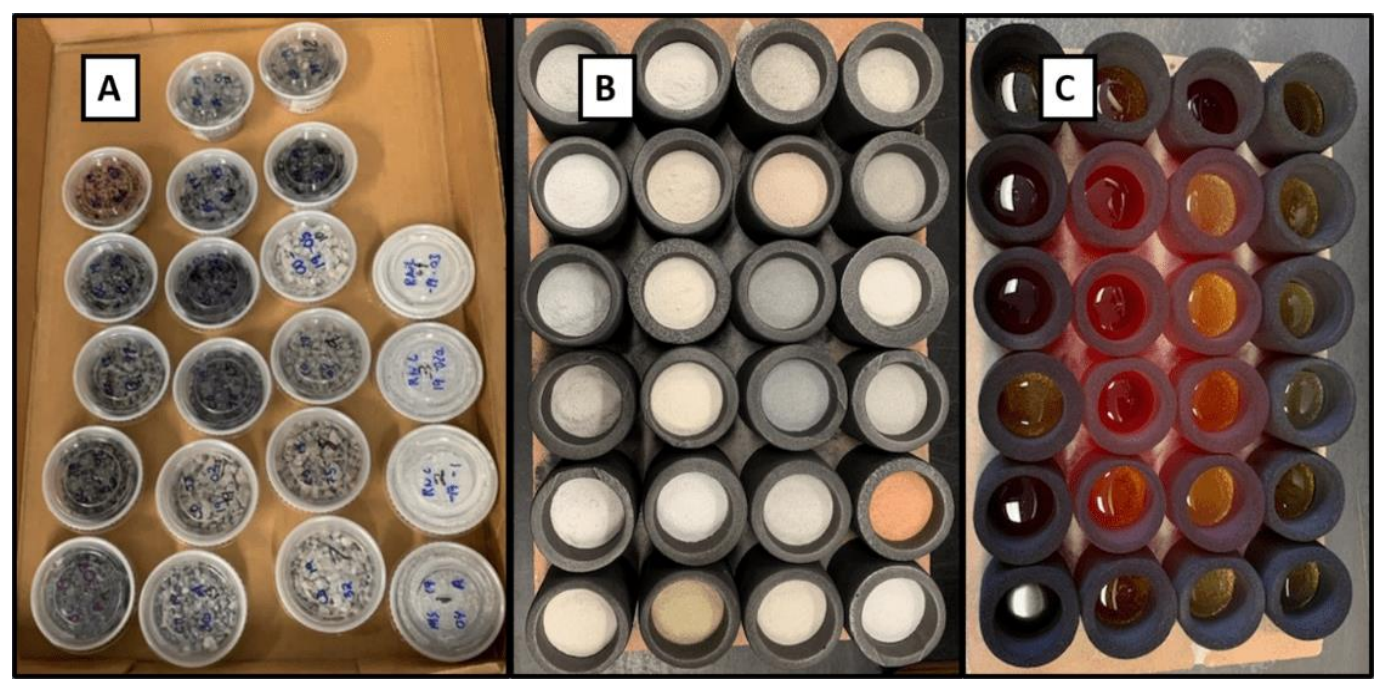

Figure 7: XRF and ICP-MS geoanalytical process conducted by Chanel Dvorak at Washington State University, Pullman Campus. (A) Rock chips were brought to WSU from PSU in the process of crushing rocks to powders. (B) Round two of crushing rocks into powders at WSU and post addition of dilithium to powdered samples and placed in carbon crucibles. (C) Samples were cooling into beads from being melted in an oven at $1000^{\circ} \mathrm{C}$. Further processes are conducted to generate XRF and ICP-MS data. 
Forty-two petrographic thin sections were prepared from JOJM quad units over the years 2017 and 2018. The samples that were analyzed signify prominent map units throughout the quadrangle. Jump-off Joe Mountain quad consisted of four regional ash-flow tuffs and twelve compositionally varying Strawberry Volcanic units. Thirty-eight petrographic thin sections were prepared for petrographic analysis from the Big Canyon quad. The samples selected for thin sections come from seventeen distinct map units throughout the $\mathrm{BC}$ quadrangle. All thin section billets were cut from the samples using a trim saw at Portland State University. The billets were roughly $4 \mathrm{~cm}$ in length, $2.5 \mathrm{~cm}$ in width, and $1 \mathrm{~cm}$ in thickness. After cutting the billets, the samples were sent to Spectrum Petrographics LLC in Vancouver, Washington, for final preparation. Full-sized thin-section photographs were taken with a Sony Alpha A7R II using a macro lens. Higher magnification photos were taken with a Canon EOS 5D Mark II using an Olympus microscope. Thin sections were analyzed at Portland State using a petrographic microscope under the plane and cross-polarized light. Mineral phases, mineral proportions, and textures were recorded for all samples, aiding in categorizing the units. Petrographic analysis of phenocrysts was conducted to provide further insight into each unit and the evidence of magma mixing or crustal contamination. In addition, thirty-four new thin sections were produced in 2020 for the LVW and MPT quadrangles.

Samples of crucial rhyolite units were used for radiometric age determination by the ${ }^{40} \mathrm{Ar} /{ }^{39} \mathrm{Ar}$ method. Two samples located in the Jump-off Joe Mountain quad, JJ-17-08 and MS-17- 05, were analyzed at the Noble Gas Mass Spectrometry Lab at New Mexico Tech. Data are composed of age dates on two rhyolite flows, Biotite-Amphibole Rhyolite and Wolf Mountain Rhyolite. The samples were crushed at Portland State University and then sieved 
to isolate feldspar phenocrysts for analysis. Sample ages were calculated using FCT-NM (R98) (4E36-14) of $28.201 \pm 0.023 \mathrm{Ma}$ (Kuiper et al., 2008). Age data were also collected from one of the rhyolite units from the BC quadrangle, Kent Spring Rhyolite (sample CD1975), at the Oregon State University Ar-Ar Geochronology facility. The sample was crushed at Portland State University and then sieved to isolate feldspar phenocrysts for analysis. Sample MS-14-23 also selected for age determinant is a rhyolite from the $\sim$ aphyric Three Cabin Spring unit in the BC quadrangle. Age dating of this sample was performed at the Ar-Ar Geochronology Research Laboratory at the New Mexico Bureau of Geology \& Mineral Resources on groundmass. Age data from previous studies (Steiner, 2016) are available for five select rhyolite samples and were used to establish stratigraphic relationships based on correlating units across areas based on lithology and chemical compositions. The analytical results for all these samples can be found in the appendix.

\subsection{RESULTS}

4.1 Distribution, Lithology, and Composition of Rock Units in the Study Area

\subsubsection{PRE-TERTIARY}

Based on the 1x2-degree Canyon Mountain quadrangle by Brown and Thayer 1966, pre-tertiary rocks of Big Canyon Quadrangle belong to the Aldrich Mountains Group. Within the Aldrich Mountains Group contains the unit (JK) Keller Creek Shale and (Rsp) Igneous and Metamorphic Rocks and thus is equivalent to Clastic Sedimentary Rocks (Itss) and Ultramafic Rocks (Kpm) of my map produced of the Big Canyon quadrangle, respectively. "The Aldrich Mountain Group is herein given to the Upper 
Triassic and Lower Jurassic rocks that form the western two-thirds of the Aldrich Mountains” (Brown, 1966). The unit Keller Creek Shale is well exposed, about 5,000 ft thick. The lower 2,500 ft. of the formation consists of massive to well-bedded, coarse- to fine-grained tuffaceous sandstone with lenses of pebbly conglomerate, shale, thin ashy beds. The Jk unit's upper and middle consists of shale interbedded with graywacke, siltstone, massive coarse- to fine-grained graywacke about $1000 \mathrm{ft}$ thick. These sedimentary units belong in general to the Izee terrane (Vallier, 1986). Unit Kpm of this study is interpreted as sheared serpentine, mostly derived from peridotite, but with original rock type not readily determinable.
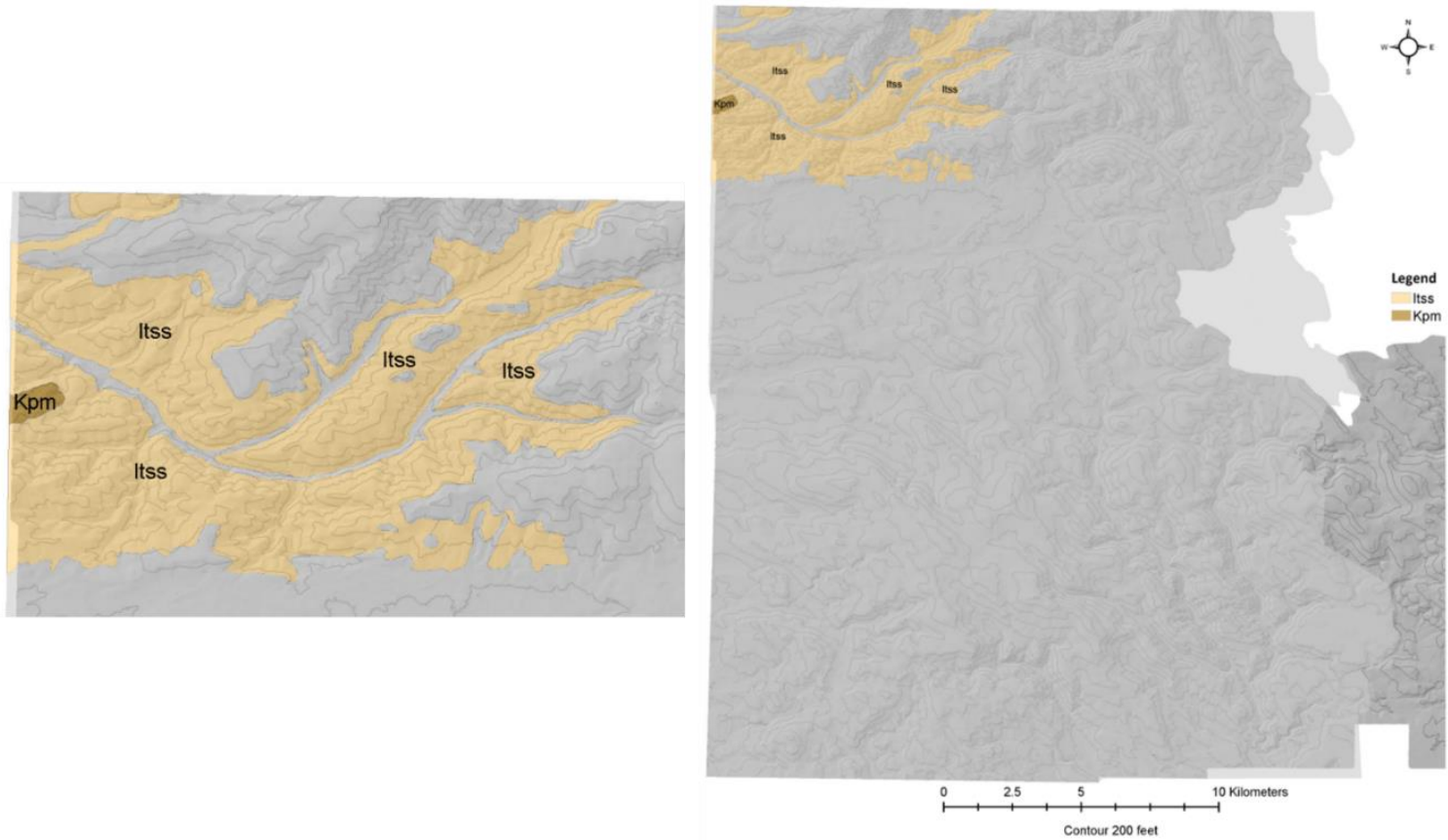

Figure 8: Distribution of the units Itss (tan) and Kpm (brown) across the entire mapping area with other units greyed out. 
I. Itss - Clastic sedimentary rocks: Conglomerate, Sandstone, Siltstone, and minor Carbonates (Mesozoic $\sim 252-66 \mathrm{Ma}$ )

The unit Itss makes up a substantial portion of the northern half of the BC quadrangle. The rocks that make up this unit are sandstone, conglomerates, siltstones, and some claystone. Occasional carbonates are exposed near the east side of the $\mathrm{BC}$ quad. Overall, this unit was primarily found in the northwest section and the west-central region of the BC map. Outcrops around the Canyon Creek bed exposed tilted bedding. They dip steeply towards the east between 70 and 90 degrees. This degree of dip is constant as you move eastward in the region of study. Overall, the east-west synclinal structure and the anticlinal orientation of geologic features in the far west indicate that this unit can be broken into more than one sandstone unit. However, no discerning factors were documented in the field, and spatial differences between sandstone units were not observed.

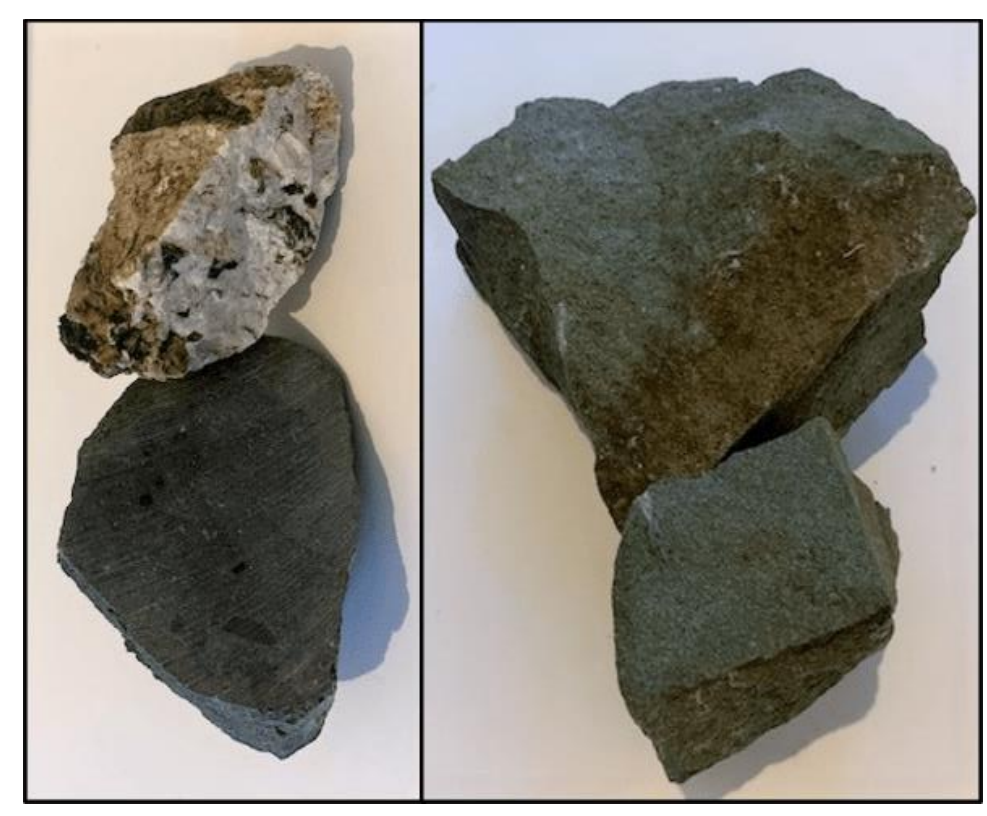

Figure 9: Sandstone of the Accreted Terranes in hand sample. The left image (sample BC19A45) is pictured with some of the unit's quartz veins throughout the sandstone in Big Canyon. The image of the right (BC19A01) has slightly more of a greenish hue. 
Itss is best identified on slightly weathered surfaces, as the fresh fine-grained interior parts resemble the aphanitic and aphyric Miocene andesite (unit Tasv). When slightly weathered, the Itss has defining characteristics. Displaying the clastic nature with sand grains and rounded lithic fragments are clearly visible with a $10 \mathrm{X}$ magnification hand lens. The surface can be dark to light tan or greenish in color, with finer-grained samples dark to light gray. The argillite beds provide most bedding orientations, indicating ample folding of the area during orogenic times. Most of the outcrops have lenticular bedding, alternated between sandstone and mudstone.

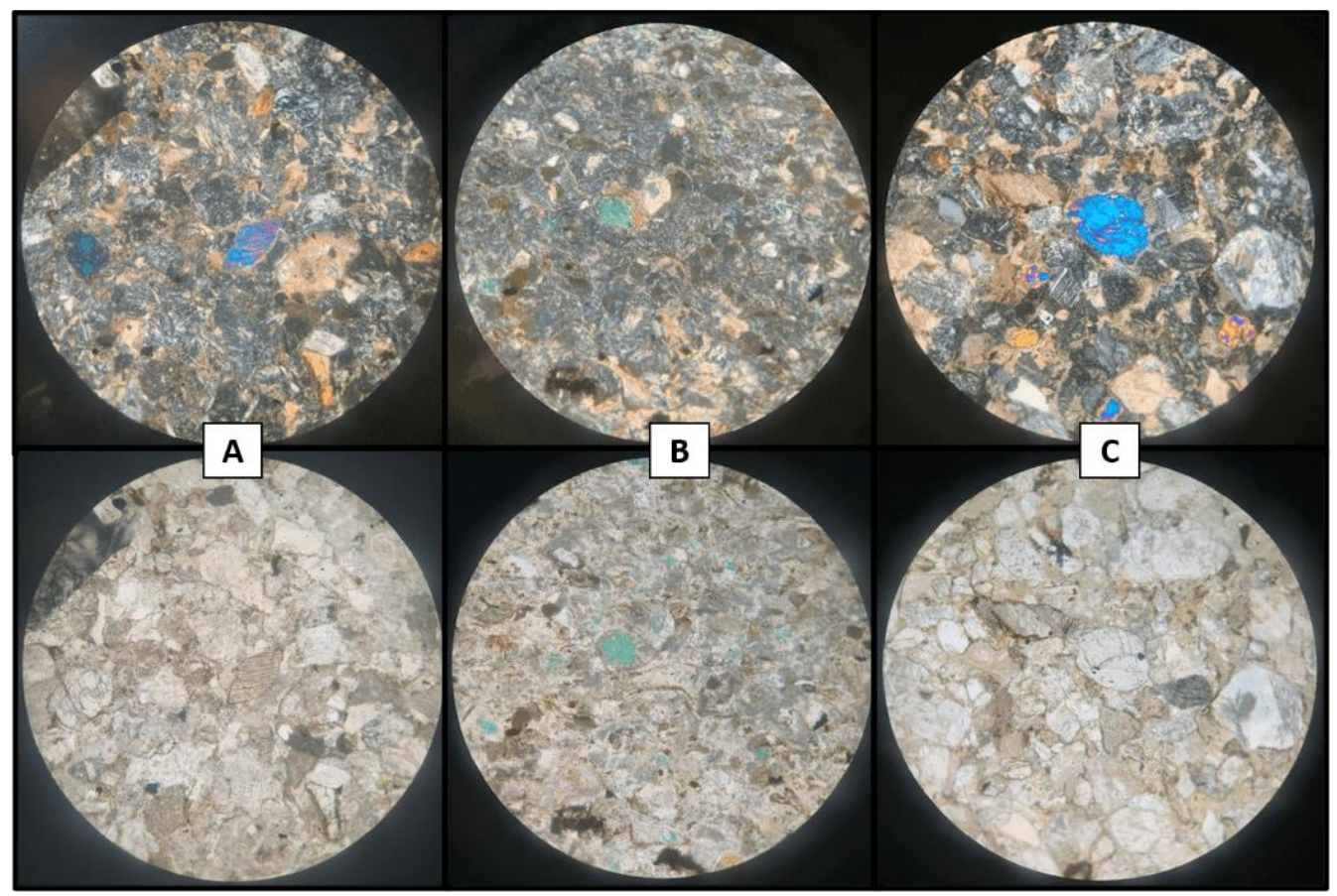

Figure 10: Thin section images of the Sandstone of the Accreted Terranes. The top row images are all in XPL, whereas the bottom is in PPL. (A) is sample BC19A45, (B) BC19A01, and (C) BC19B06. All pictured are in 100X optical zoom.

Thin-section analysis of sample BC19A01 (Image B Figure 10) shows alteration of plagioclase altering to epidote. Itss show pleochroic teal, clay chlorite that leads in hand 
samples to the greenish-blue hue of the rock. It is a subangular-subrounded fine-grained sandstone displaying weathered minerals indicative of andesite (pyroxene, plagioclase) or possibly more mafic protoliths. About five percent of quartz grains are present. In image B, chlorite patches indicate alteration of the mafic minerals such as amphiboles and pyroxenes. A whole thin section comprises approximately $5 \%$ of dark lithic fragments. In Figure 10, image A, sample BC-19-A-45, is much less altered than image B. Fragments of siltstone, shell fragments, and lithics are seen within this sample. Clinopyroxene and amphibole are also present, characterizing this sample as part of a volcaniclastic unit. The pre-Tertiary unit Itss has an average $\mathrm{SiO}_{2}$ content of about $65 \mathrm{wt} . \%$ but analyzed samples range from $\sim 57.9$ to 71.3 $\mathrm{SiO}_{2}$ wt. $\%$, and $\mathrm{Al}_{2} \mathrm{O}_{3}$ values range from 13.9 wt. $\%$ to 16.5 wt. $\%$. The average $\mathrm{CaO}$ content is 6.7 wt. $\%$.

\section{Kpm - Ultramafic Rocks (Paleozoic $\sim 541-251 \mathrm{Ma}$ )}

The oldest unit found in the project region is a recognized ophiolite and includes mafic-ultramafic rocks, serpentinite, and a chert-argillite mélange (Steiner, 2018). Kpm only was found in a small section to contact unit Itss to the west in the $\mathrm{BC}$ quadrangle and appears to consist mainly of what used to be pyroxenite upon outcrop inspection. 


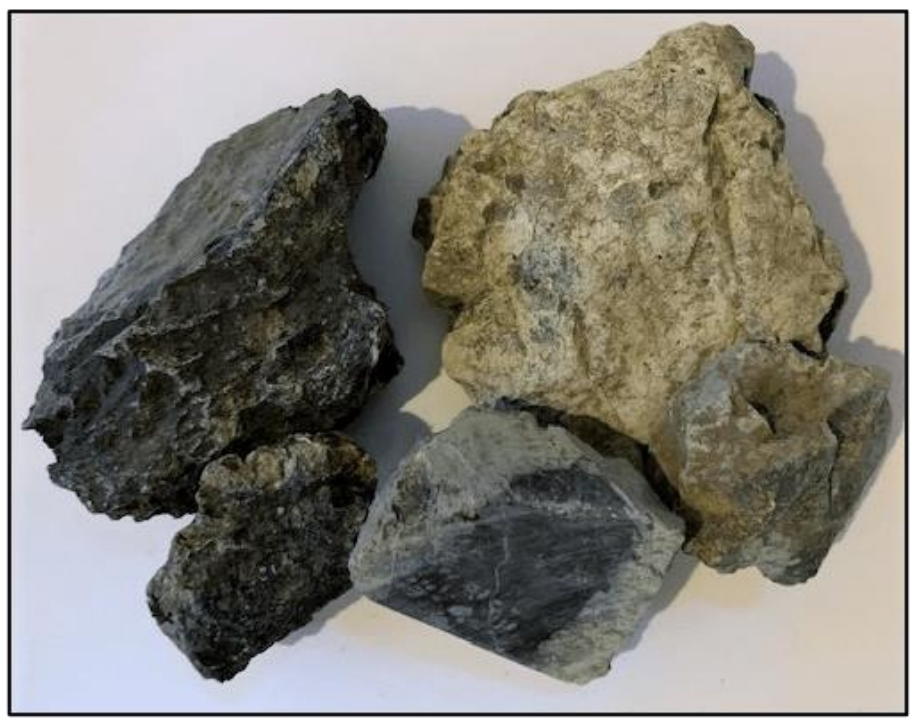

Figure 11: Pictured is the Pretertiary Ultramafics, Sample BC19A07.

The Kpm unit in the hand sample appears nearly black or a weathered green hue and is mainly composed of talc and serpentine. Only pseudomorphs after pyroxene up to three $\mathrm{cm}$ in size are apparent in hand samples. 


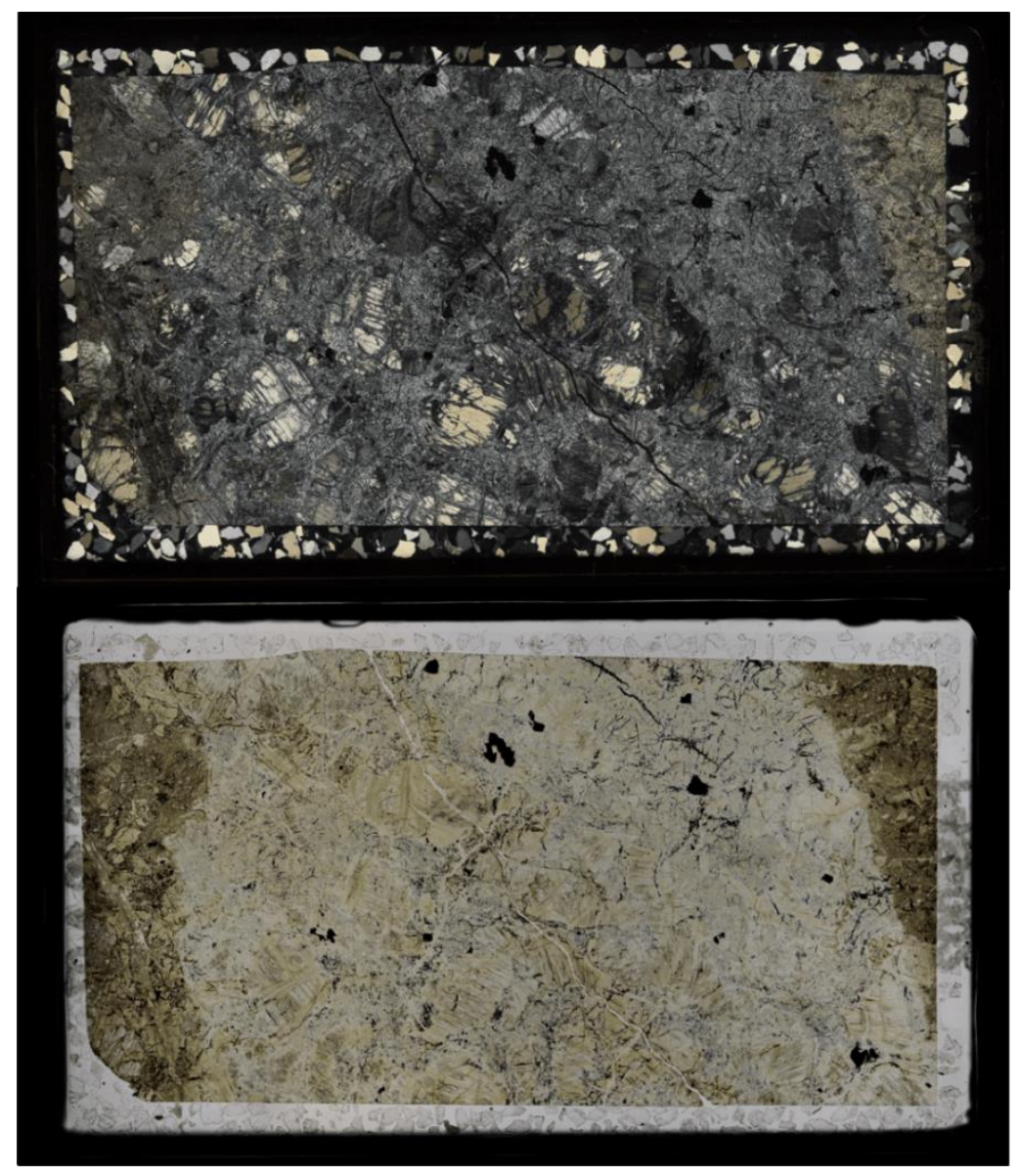

Figure 12: Full thin section image of sample BC19A07, Pretertiary Ultramafic unit. The upper image is in XPL, and the lower is in PPL. 


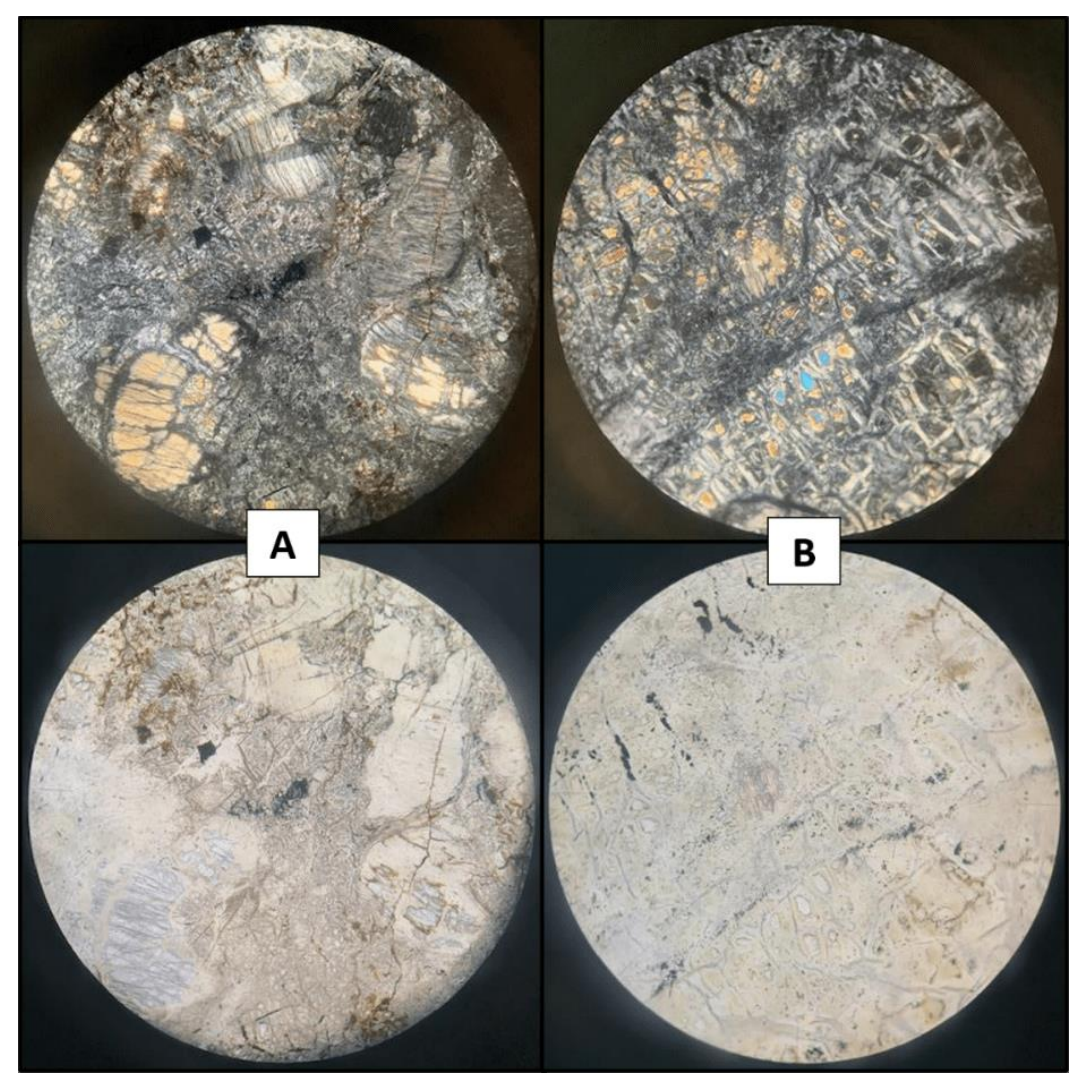

Figure 13: Thin section images of sample BC19A07 all captured in 100X optical zoom. The top row of images is in XPL, and the bottom row is in PPL.

Investigating a thin section of Kpm (sample BC19A07), the sample is indeed classified as pyroxenite. Abundant large pyroxenes have altered to serpentine and talc with a mesh-like texture. Pictured in Figure 13, the weathered pyroxene grains make up most of the field of view. Unit $\mathrm{Kpm}$ has a low $\mathrm{SiO}_{2}$ content of 47.49 wt.\%, a FeO* content of 8.56 wt.\%, and a high $\mathrm{MgO}$ content of around $40 \mathrm{wt} . \%$. All ICP-MS trace element concentrations are depleted in comparison to neighboring units. On the other hand, the $\mathrm{Ni}$ and $\mathrm{Cr}$ contents are high, with 2233 ppm and 2872 ppm values. These compositional features support and are in keeping with being initially a pyroxenite. 


\subsubsection{REGIONAL TUFFS}

\section{Trst - Rattlesnake Tuff (7.1 Ma)}

The Rattlesnake Tuff (Trst) is a widespread, single cooling unit and displays variable welding characteristics from non-welded to densely welded with vapor phase and lithophysae zones (Streck and Grunder, 1995). Most of the RST is high-silica rhyolitic tuff (75-77.5 wt. $\% \mathrm{SiO}_{2}$ ) but with some dacitic components (62-70 wt. \% $\mathrm{SiO}_{2}$ ) found in pumices and banded pumices. Dacite pumices occasionally contain mafic inclusions that range from andesitic to basaltic (Streck and Grunder, 1999). Rattlesnake Tuff can be distinguished from other tuffs lithologically and geochemically.

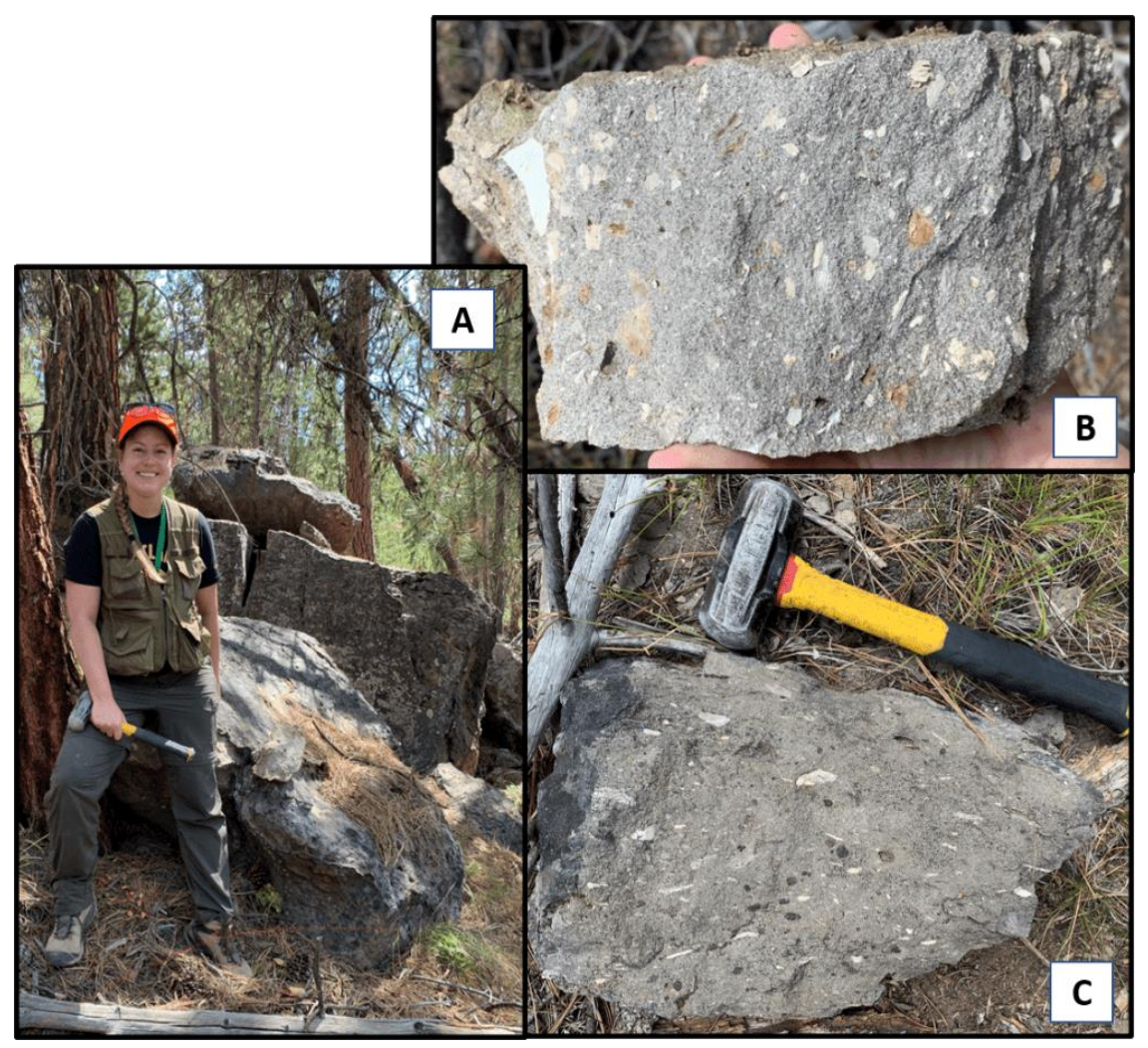

Figure 14: Image B and C are examples of typical partially welded vitric hand samples of Rattlesnake Tuff, all from the outcrop in image A. Visible features are light to gray pumice clasts in gray glass shard matrix. Image A (Sample CD1988) is in the southern-central region of the quadrangle. 
The tuff is typically exposed to 5-20 m thick outcrops, which often caps flat-lying plateaus (Streck and Grunder, 1995). However, in my study area, outcrops of Trst typically are less than $10 \mathrm{~m}$ in thickness and dip at a few $(\sim 5)$ degrees in an easterly direction. Typical hand samples of the tuff are light to middle gray and light reddish to pinkish red, often vitric containing $\sim 1 \%$ phenocrysts. Trst is typically pumiceous, glassy, and ranging from incipiently welded to welded. Pumices can be white, gray, and black, and banding of any combination of these colors. The 7.1 Ma Rattlesnake Tuff overlies Devine Canyon Tuff and Dinner Creek Tuff unit 1 on the northwestern and southeastern corner of the BC quad and some sparse northern and southern regions of the JOJM quadrangle. Trst roughly covers an area of $\sim 108 \mathrm{~km}^{2}$ with a minimal calculated volume of $\sim 1 \mathrm{~km}^{3}$. Distinguishable from other tuffs by the vitreous fresh glassy groundmass, white pumice up to $10 \mathrm{~cm}$ in length, and virtual nearly aphyric character $(\sim 1 \%$ phenocrysts mostly alkalifeldspar and quartz). Hand samples of Trst may contain some fiamme when welded. This tuff may display some horizontal parting parallel to the welding plane and is consequently platy in outcrop. 


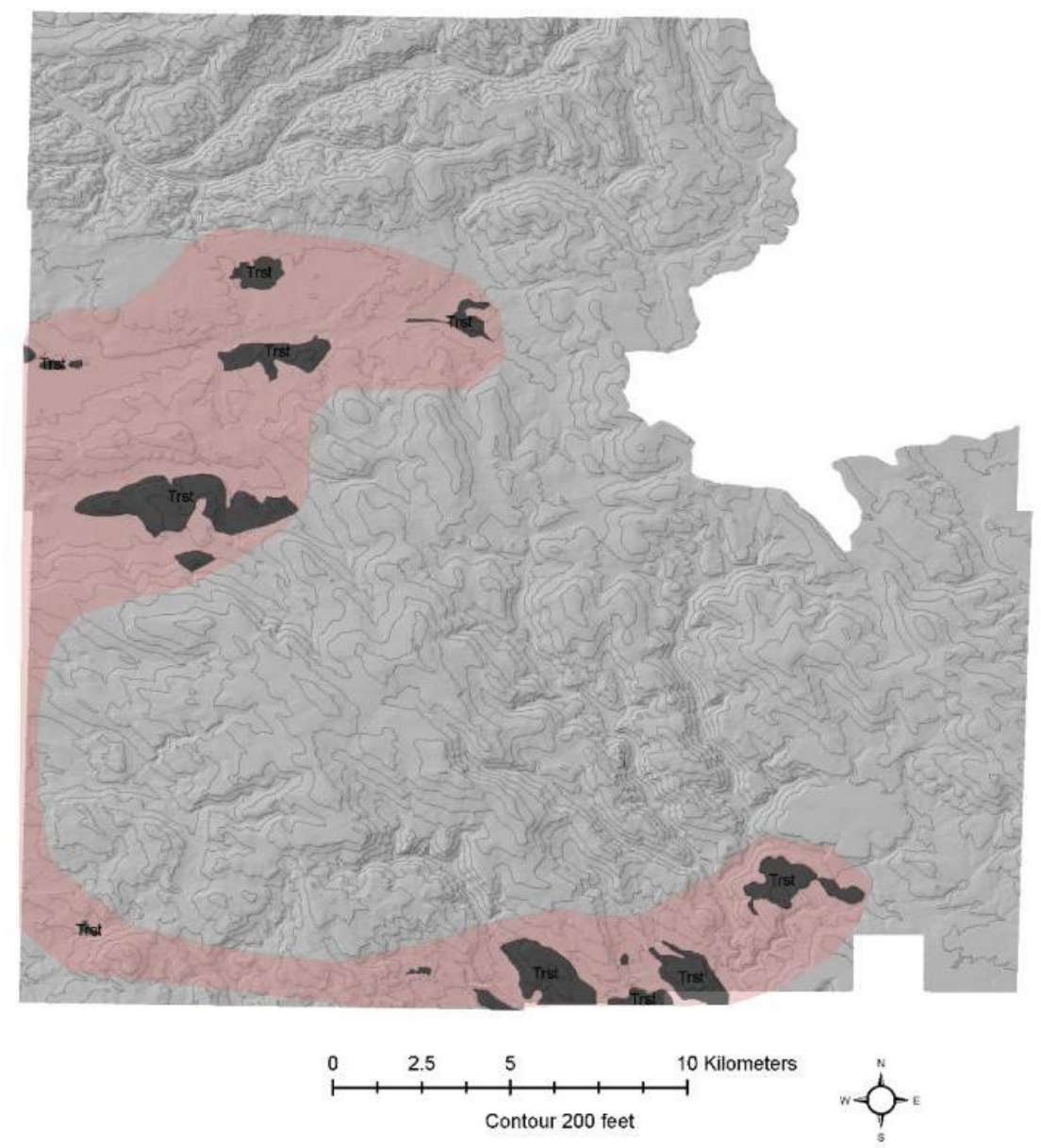

Figure 15: Distribution of the unit Trst (red) across the entire mapping area with other units greyed out.

II. Tdet - Devine Canyon Tuff (9.7 Ma)

The Devine Canyon Tuff is one of the largest late Miocene ash-flow tuffs in eastern Oregon, extending over 20,000 $\mathrm{km}^{2}$ (Wacaster and others, 2011) with a reported Ar-Ar date of 9.74 $\pm 0.02 \mathrm{Ma}$ (Jordan et al., 200). The Devine Canyon Tuff is part of the High Lava Plains volcanic province. The erupted source is believed to be a caldera located in the Harney Basin, near Burns (Jordan et al., 2004). Tdct is almost entirely composed of rhyolite (74.6-77.6 wt.\% $\mathrm{SiO}_{2}$ ) with a dacitic component (68.7-68.9 wt.\% $\left.\mathrm{SiO} 2\right)$ found as 
individual pumices or as streaks within banded pumices, comprised of both rhyolite and dacite (Isom, 2017). The Devine Canyon Tuff is the oldest of the three ash-flow tuff units that erupted from the Harney Basin to the south and overlay Dinner Creek Tuff unit 1 and older volcanic units.

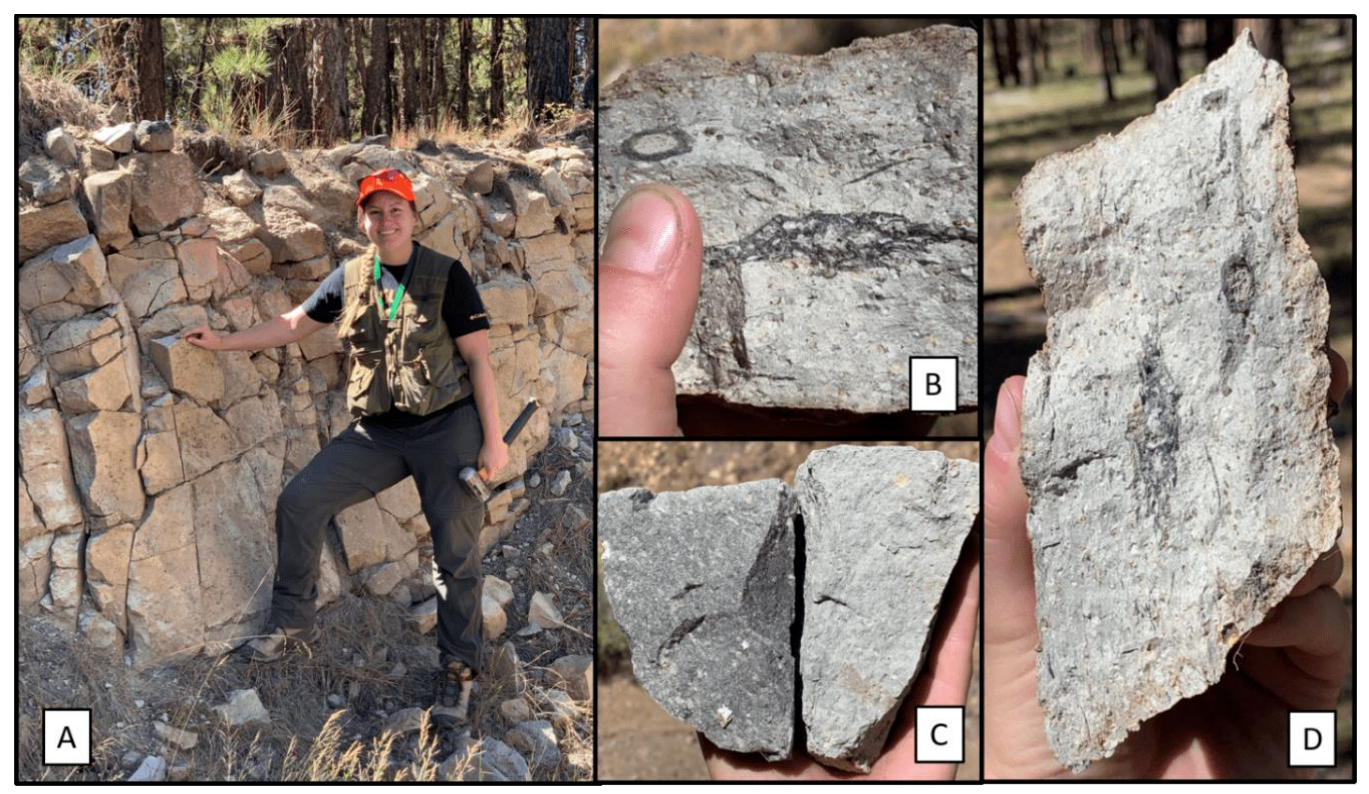

Figure 16: Image A is an outcrop of Devine Canyon tuff within the Big Canyon quadrangle. The black streaks amongst the outcrop hand samples seen in pictures B and D are fiamme (flattened pumices). Hand samples seen in image $\mathrm{C}$ show the variance in color throughout this unit.

The Tdet that crops out in the study region is primarily found in the western-central and southwest parts of $\mathrm{BC}$ and sparse northern and southern sections of the JOJM quadrangles. Typically, Tdct in my region is about 5-15 meters thick. It can be up to 50 meters closer to the source (Figure 16). Tdct roughly covers an area of $\sim 160 \mathrm{~km}^{2}$ with a minimal calculated volume of $\sim 1.6 \mathrm{~km}^{3}$. The tuff is partial to densely welded, typically outcrops as rounded boulders. Eroded Tdct has a unique feature as the abundant phenocrysts generate very sparkly sands. Outcrops are dark grey to light grey in color. This 
unit contains vitric, devitrified, and vapor phase zones. The ignimbrite generally exhibits stratigraphic gradation in phenocryst content from phenocryst-poor $(<5 \%)$ in basal sections to phenocryst-rich $(>25 \%)$ in the uppermost portion (Isom, 2017). Typically, Tdct contains $\sim 25 \%$ crystals of alkali feldspar in a hand sample and noticeable quartz phenocrysts with trace amounts of clinopyroxene and fayalite. The tuff forms a single cooling unit, which suggests the entire magma chamber erupted during a single eruptive episode (Isom, 2017). In the thin section, the tuff is effortlessly distinguishable from other tuffs in the area due to its high phenocryst percentage (Figure 17). Devine Canyon Tuff is slightly peralkaline rhyolite with high $\mathrm{Zr}$ (>700 ppm), high Nb (>53 ppm), Ce (152 - 196 $\mathrm{ppm})$, and low $\mathrm{Ba}(183-216 \mathrm{ppm})$ content. Outcrops of Tdet in the study region vary in their welding degree, but observed sections are mostly densely welded. Vitric groundmass consists of glass shards, pumice, and lithic fragments. Fiamme is also found in several sections within the mapped region. On the other hand, lithophysae or spherulites have not been observed in the tuff. Select samples were analyzed for major and trace elements and plotted in Figure 19 along with other regional tuffs of this study. 


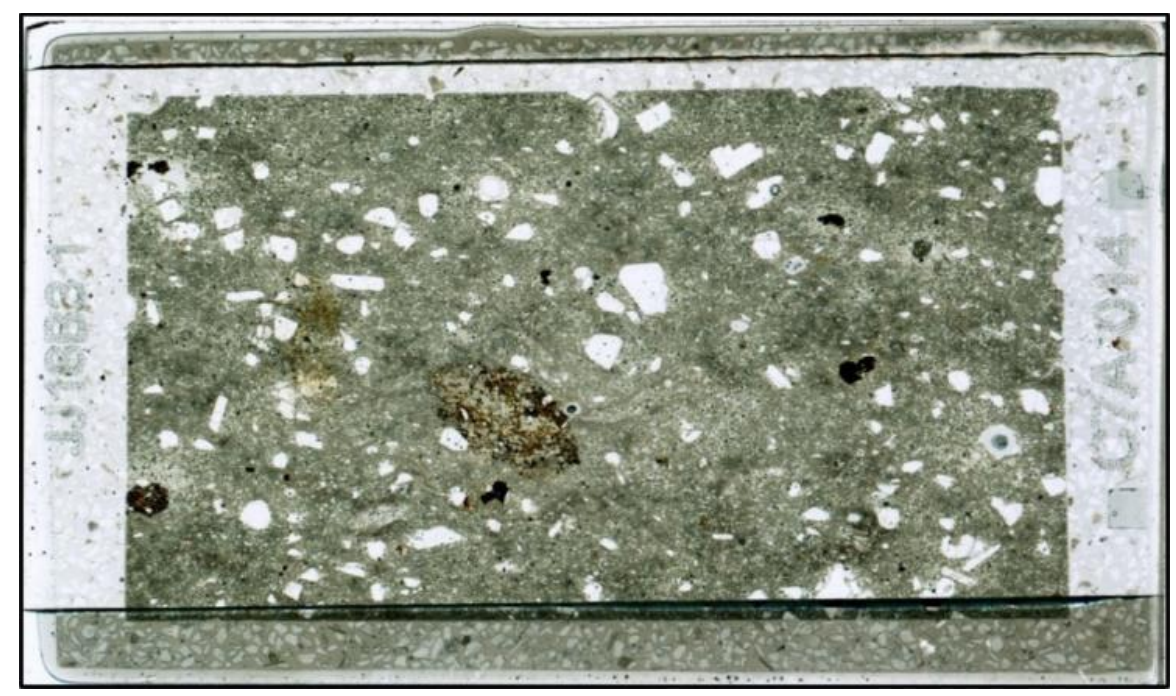

Figure 17: Full slide thin section image of Devine Canyon tuff (sample JJ18B3.1) shown in PPL. Displays glassy (ash) matrix with quartz phenocrysts.

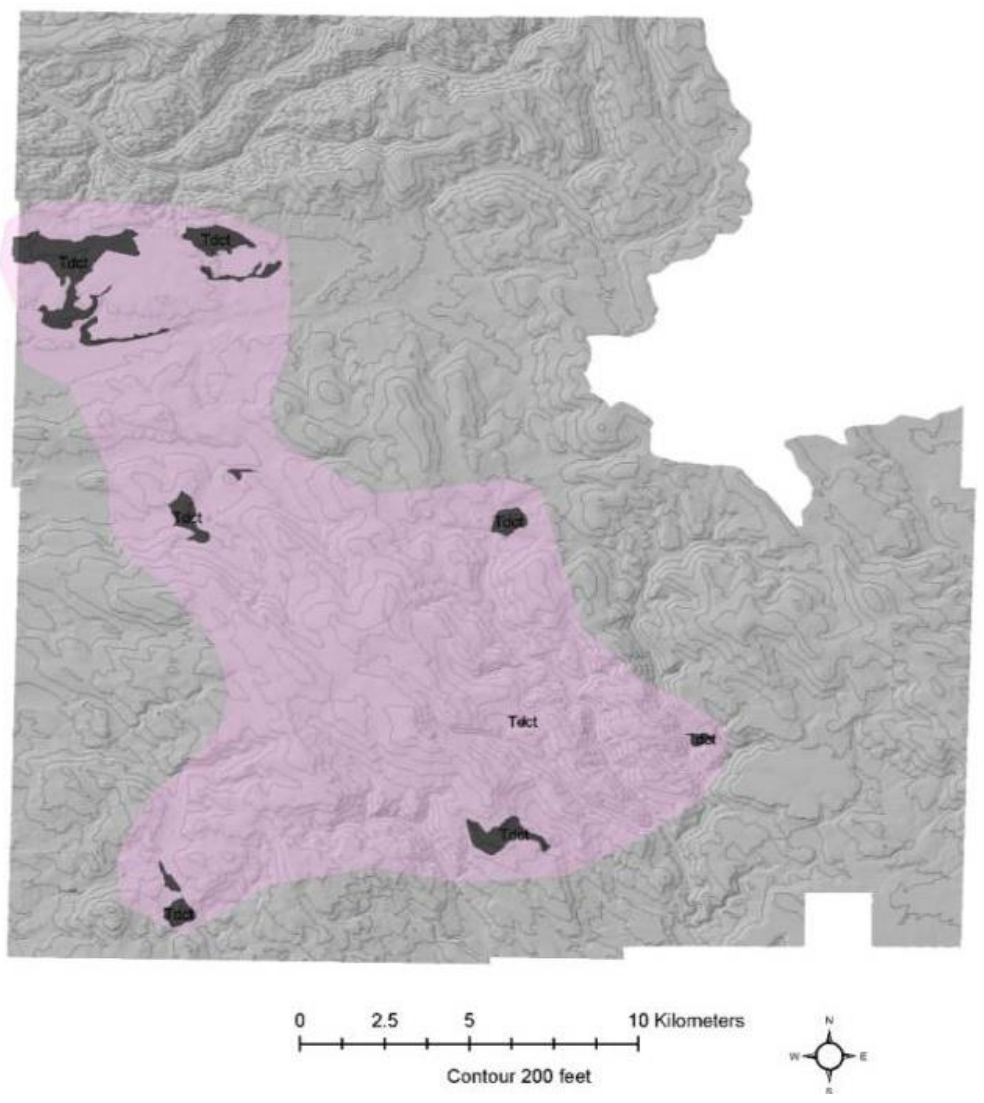

Figure 18: Distribution of the unit Tdct (pink) across the entire mapping area with other units greyed out. 


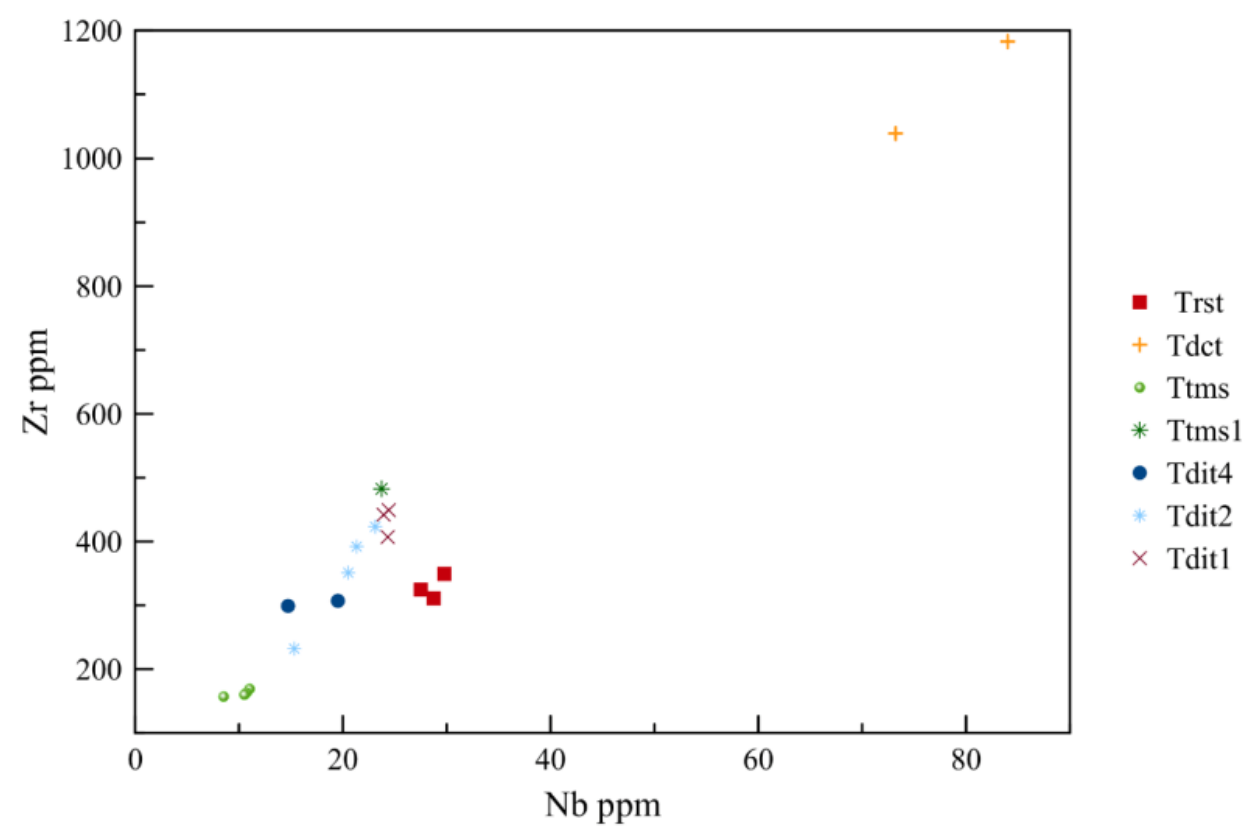

Figure 19: Zr versus $\mathrm{Nb}$ of all regional to local silicic ash-flow tuff units.

\section{Tdit4 - Dinner Creek Tuff, Unit $4(15 \mathrm{Ma})$}

The four Dinner Creek Tuff units are all regionally distributed ignimbrites and erupted during a period of mid-Miocene rhyolitic volcanism coeval to the flood volcanism of the CRBG (Streck and Ferns, 2012; Streck et al., 2015). Source caldera(s) for the four discrete ignimbrites that make up the Dinner Creek are believed to lie in the Castle Rock-Ironside Mountain area northeast of the town of Burns (Rytuba and Vander Meulen, 1991; Streck et al., 2015; Cruz, 2017) The Dinner tuff unit 4 unit is the youngest with an age of around $15 \mathrm{Ma}$ (Streck et al., 2015; Hanna, 2018); it roughly covers an area of $\sim 82 \mathrm{~km}^{2}$ with a minimal calculated volume of $\sim 0.5 \mathrm{~km}^{3}$. It is the most mafic of the Dinner Creek units with a bulk composition of dacite but consisting of juvenile components ranging in composition from rhyolite to basaltic andesite. The other Tdit units are rhyolitic tuffs 
displaying nearly identical compositions but with subtle geochemical and lithological differences and distinct unit ages (Streck et al.,2015). Hand samples of Dinner Creek Tuff cooling units 1, 2, and 3 strongly resemble one another. When devitrified, samples without eutaxitic texture are difficult to distinguish from samples of devitrified rhyolite lava flows considered part of the lower Strawberry Volcanics (Ferns et al., 2017).

The bulk composition of the Tdit4 tuff deposit is lower in $\mathrm{SiO}_{2}$ than the other Tdit cooling units due to the substantial comingling of dacite and andesite components with high-silica rhyolite. Given its dacitic bulk composition, Tdit4 is also depleted in most trace elements, except for compatible elements such as $\mathrm{Sr}$, which are enriched compared to rhyolitic units (Streck et al., 2015). For example, sample CD1936A has a Sr value of 135 ppm, whereas Tdit units 1 and 2 found in the quadrangle to the south (Jump-off Joe Mountain) have a lower Sr value, $\sim 30 \mathrm{ppm}$ for Tdit1 and $\sim 90 \mathrm{ppm}$ for Tdit2. Outcrop thickness is roughly 3-8 $\mathrm{m}$. This unit is found throughout the Big Canyon quadrangle, with its largest outcrop occurring in the far southwestern region.

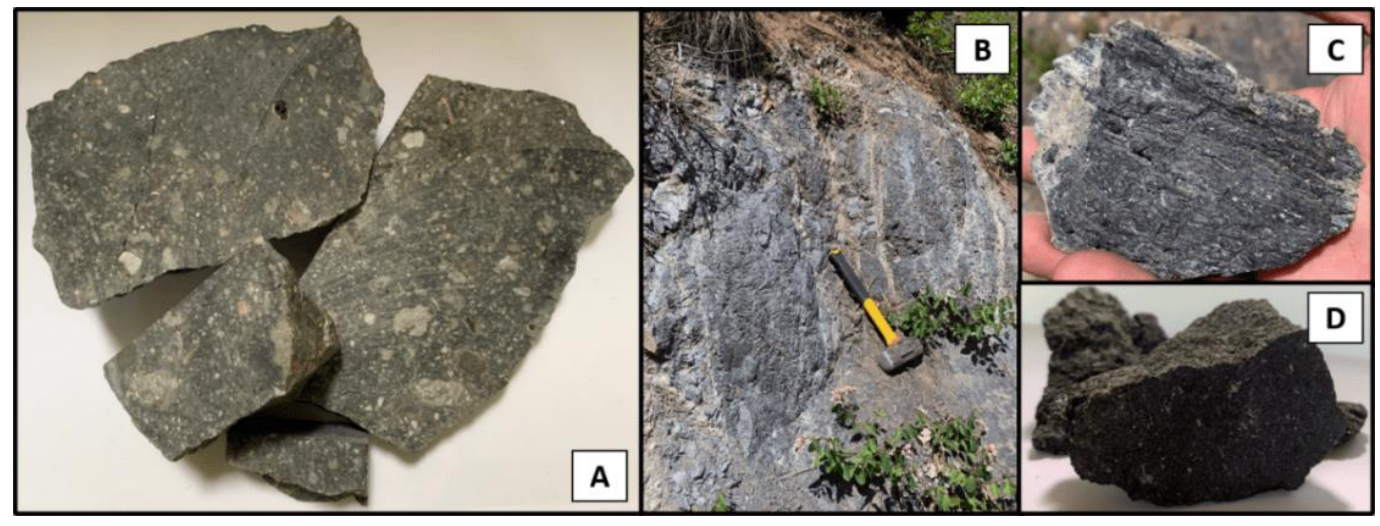

Figure 20: Image (A) sample BC19A26B, (B and C) outcrop and hand sample CD1936A, lastly image (D) sample BC19C40. 
Typically, Tdit4 may contain up to $\sim 15 \%$ lapilli-sized fragments of juvenile and lithic nature in the hand sample. Lithic fragments appear to be mostly derived from older lavas and tuffs of the surrounding region. This unit is typically much darker in color due to its more dacitic composition and often appears to have a glassy groundmass compared to the other Tdit members (Figure 20). The welded vitrophyre is often more friable in outcrop, making hand samples much more delicate to handle than the surrounding tuff units. In hand samples, fiammes are often seen, welded glass shards, dacitic lapilli lithics, occasionally pumice, and lithics ranging in size from about $1-20 \mathrm{~cm}$. The thin section pictured in Figure 21 is Tdit4 sample BC19A26B from the BC quad. This thin section image is a perfect example of the mafic lithic fragment incorporated in the tuff. Thin sections reveal a phenocryst percentage of $\sim 3-5 \%$ feldspar and $\sim 1 \%$ subhedral pyroxene. The feldspars are primarily plagioclase, as indicated by the albite twinning. The groundmass typically consists of variably welded glass shards.

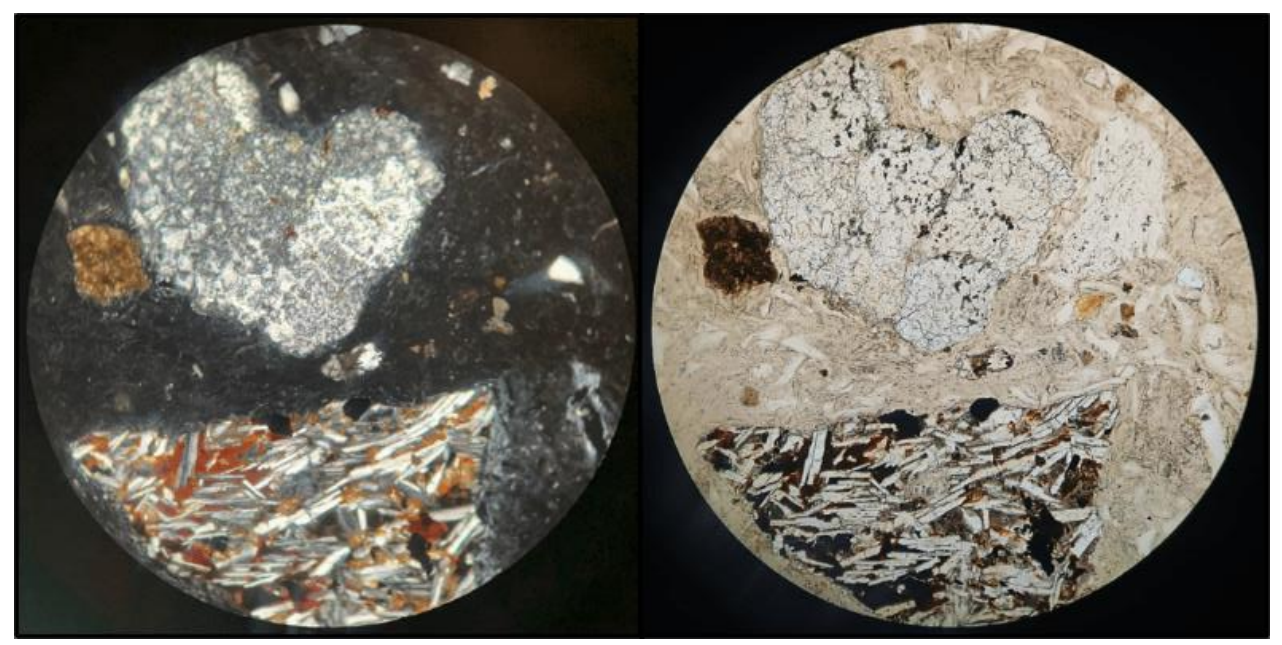

Figure 21: Image of Tdit4 sample BC19A26B. The left image is in XPL, whereas the right is in PPL, represented in $100 \mathrm{X}$ optical zoom. 


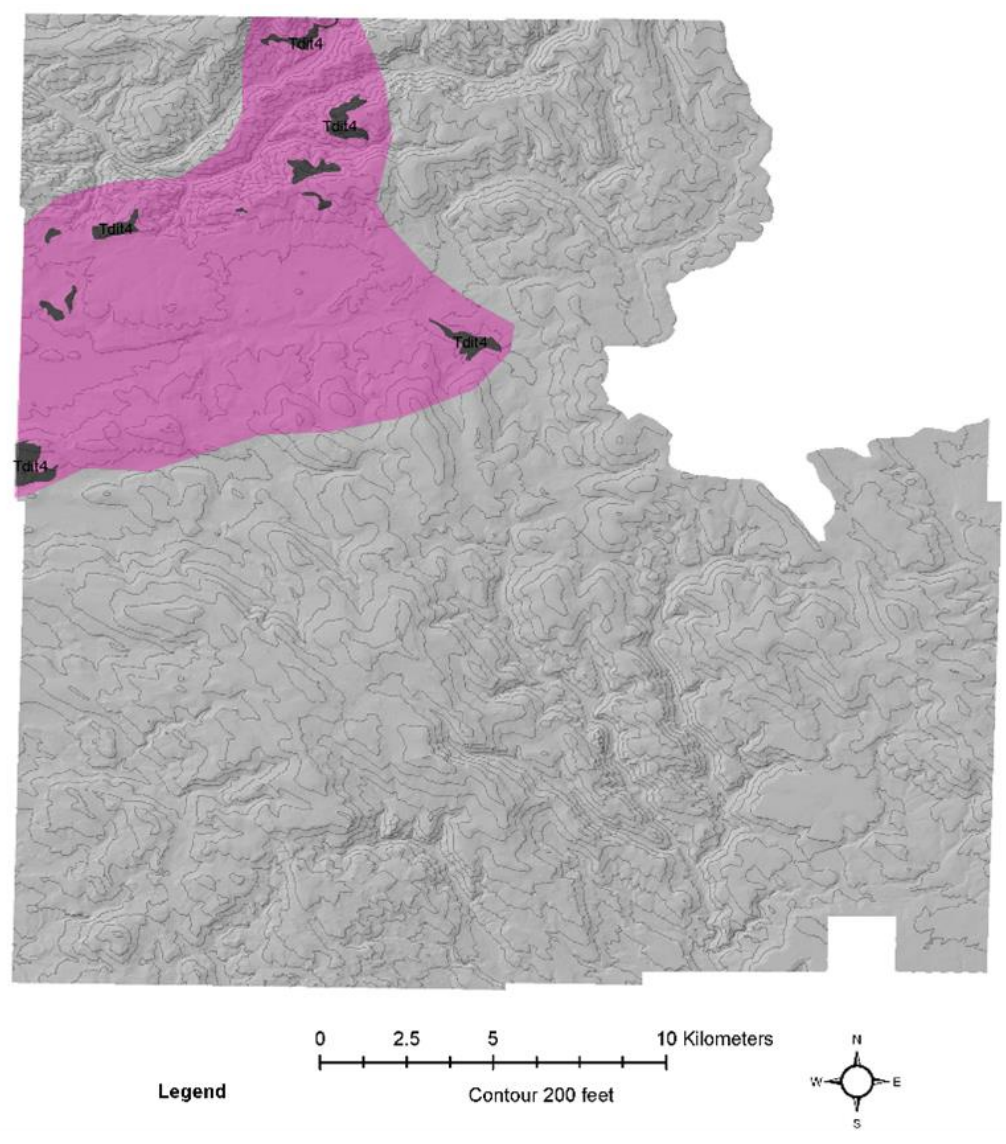

Figure 22: Distribution of the unit Tdit4 (magenta) across the entire mapping area with other units greyed out.

\section{Tdit2 - Dinner Creek Tuff, Unit 2 (15.5 Ma)}

The second oldest unit of the Dinner Creek Tuff has an age of 15.5 Ma. Outcrops are poor, appearing only in the south-central region of the JOJM mapping area, mainly along the eastern flank of Long Mountain. The tuff is mostly incipiently welded. The groundmass of the tuff ranges from tan to gray in color, and small (mostly $\sim 2 \mathrm{~cm}$ ) gray to white pumices are common and black glassy lithic fragments. Feldspar phenocrysts make up about $5-10 \%$ of the rock. The tuff is less than 10 meters thick. Tdit2 roughly covers an area of $\sim 28 \mathrm{~km}^{2}$ with a minimal calculated volume of $\sim 0.2 \mathrm{~km}^{3}$. Some sections include a partially welded zone as defined by vitrophyre grading upward into less welded tuff. The presence of large, dark- 
colored, scoriaceous pumice fragments (up to 30-40 centimeters) and obsidian lithic fragments (up to $15 \mathrm{~cm}$ ) suggest close proximity to the Dinner Creek vent. Exceptionally large pumice fragments were found at some of these outcrops.

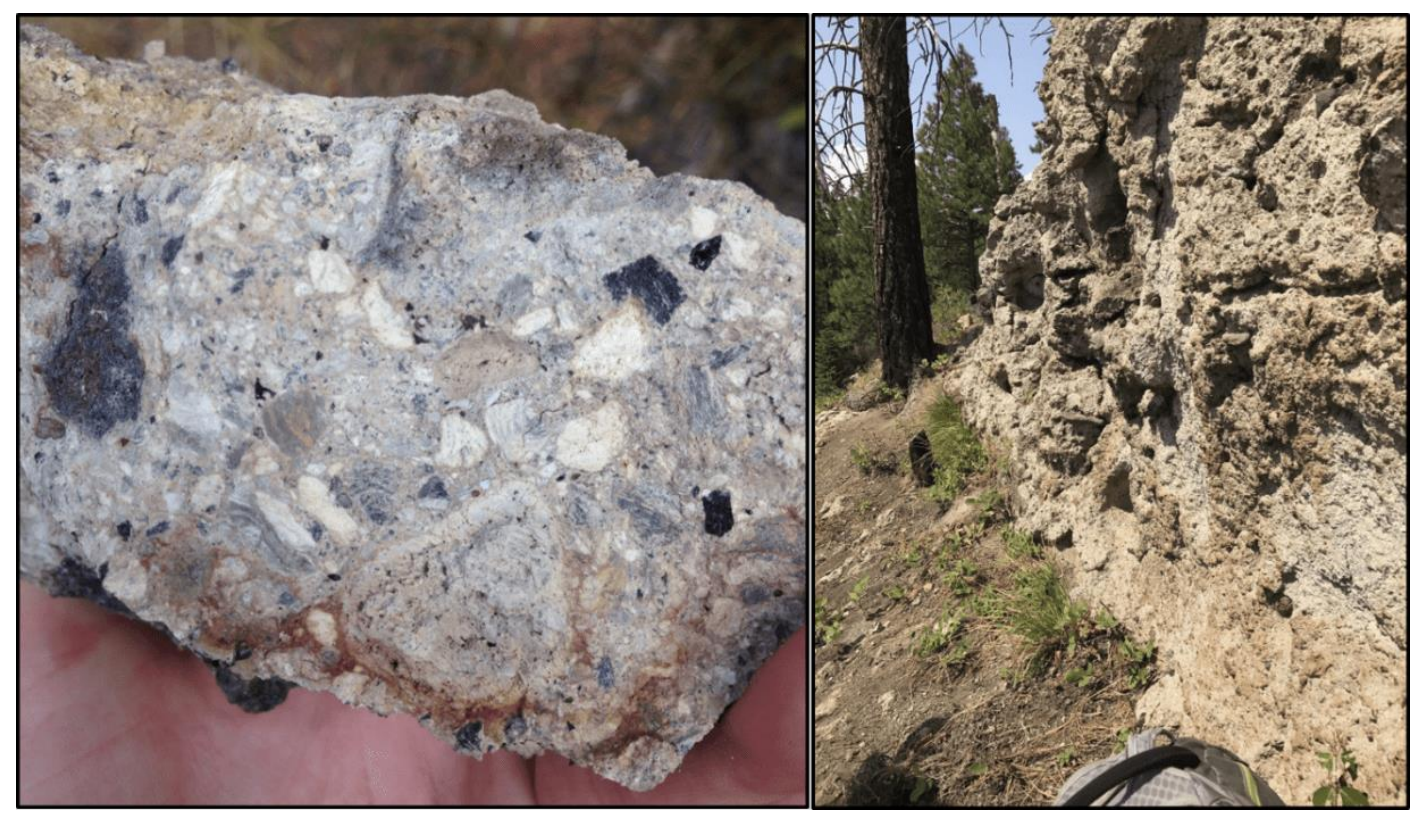

Figure 23: On the left is a hand sample of Dinner Creek Tuff unit 2. The right image shows this unit in an outcrop.

The most abundant phenocryst in Tdit2 is plagioclase with a composition of $\sim 20$ An (Streck et al., 2015). Geochemically, the tuff can be distinguished from the Dinner Creek Tuff unit 1 by its lower wt. \% SiO2 (72-74) and lower Y ( 50 ppm) but higher Sr content (>100 ppm) (Ferns et al., 2017). Dark-colored pumices are iron-rich with 5.2 wt. \% FeO*. Dinner Creek Tuff unit 2 erupted from a caldera located at Ironside Mountain, about $148 \mathrm{~km}$, to the northeast of the project area (Cruz, 2017). 


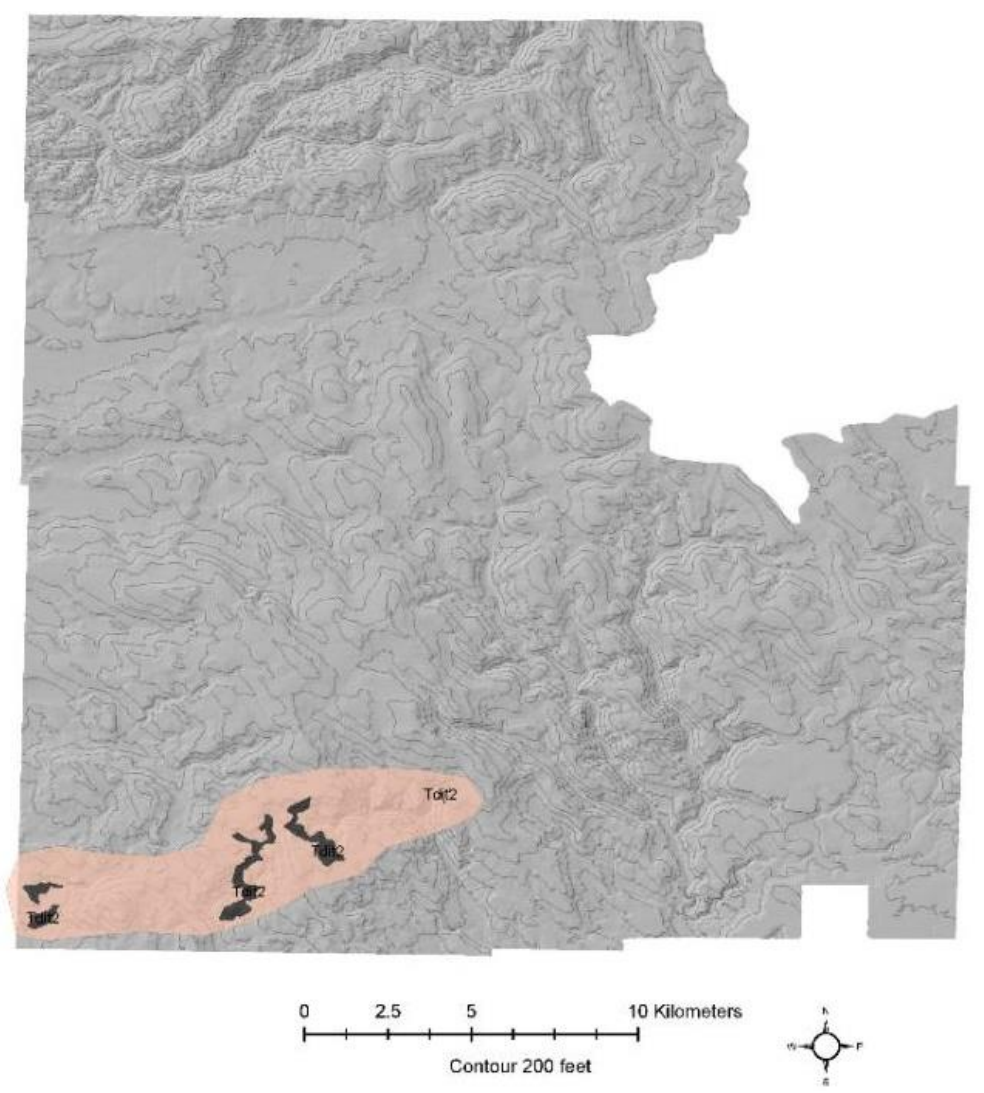

Figure 24: Distribution of the unit Tdit2 (peach) across the entire mapping area with other units greyed out.

\section{Tdit1 - Dinner Creek Tuff, Unit 1 (16.1 Ma)}

Outcrops of the Dinner Creek Tuff unit 1 are widely distributed across the JOJM study area with variable thickness, suggesting a variable paleo-topography at the time of the eruption., Tdit 1 is also found within the west-central portion of the BC map and in a small southern region of the MPT quad. The Dinner Creek Tuff unit 1 is the oldest, dated at 16.15 Ma, and is the most extensive of the Dinner Creek Tuff units (Hanna, 2018). Tdit1 is lithologically variable, ranging from rheomorphic to lithophysal sections, with a basal vitrophyre in outcrop or as float of glassy tuff found. In general, this unit is the thickest unit of the Dinner Creek Tuff, also in the project area, with maximal thicknesses ranging 
from about 20 to 80 meters. Average outcrop thickness is between $\sim 3 \mathrm{~m}$ and $\sim 30 \mathrm{~m}$, with some of the thickest exposures found near road cuts and drainages. Tdit1 roughly covers $\sim 140 \mathrm{~km}^{2}$ with an estimated, calculated volume of $\sim 2.3 \mathrm{~km}^{3}$. Sections with lithophysal tuff or where the tuff is rheomorphic appear to be sections where the tuff was originally thickest.

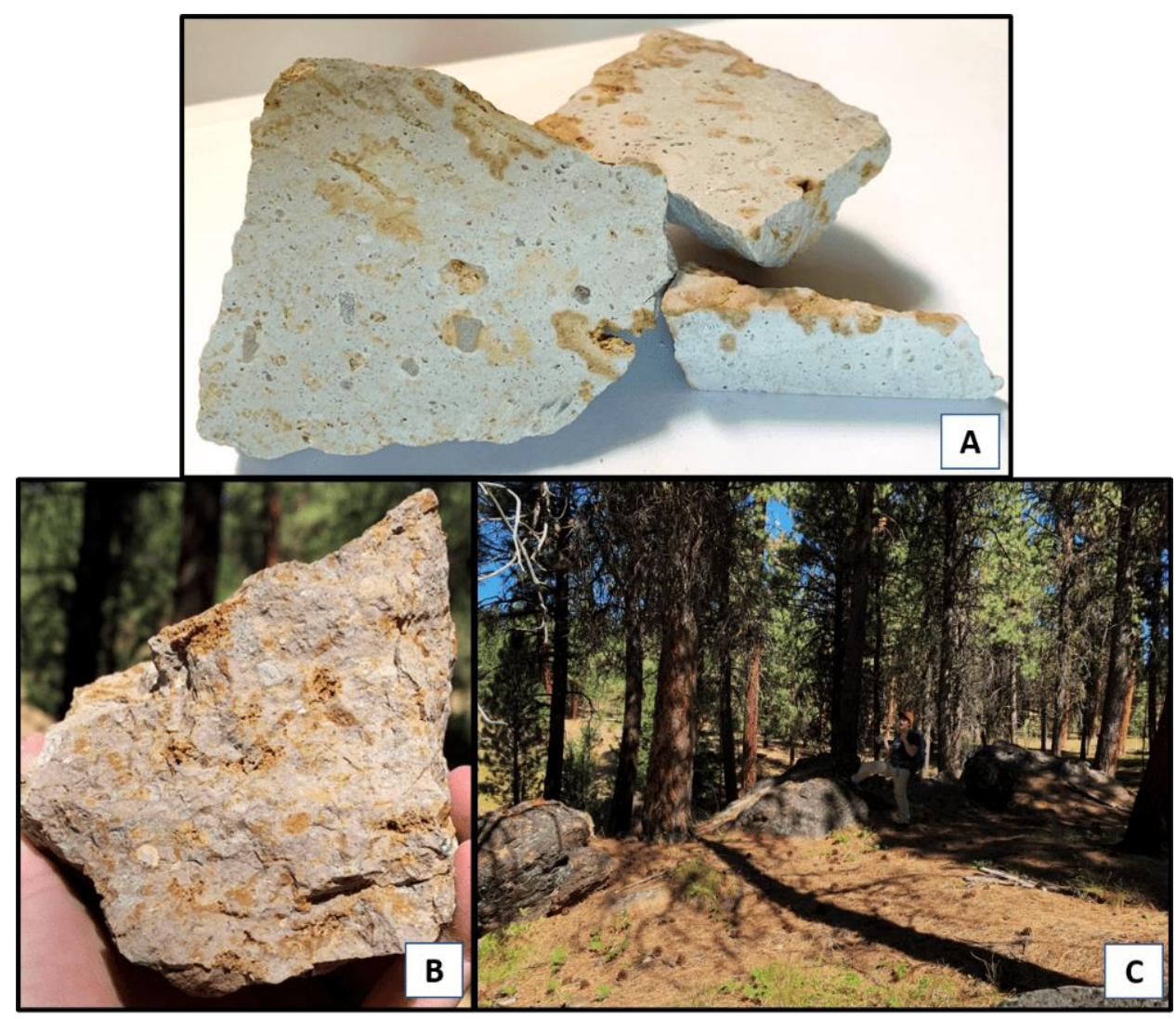

Figure 25: Dinner Creek Tuff unit 1 is found in varying shades of color and alteration, basal vitrophyre, spherulitic tuff, and devitrified. Image A is from sample BC19A61, where B and C are from sample CD1979.

In thin section, the groundmass is typically welded glass shards with about 3-5 percent, plagioclase phenocrysts showing albite twinning and altered clinopyroxene about $0.5-1$ 
$\mathrm{mm}$ in length. A thin section of rheomorphic tuff exhibits about $1 \%$ phenocrysts with a devitrified pinkish groundmass.

Dinner Creek Tuff unit 1 has the highest silica content of all the Dinner Creek Tuff units, typically greater than 75 wt. $\% \mathrm{SiO}_{2}$ and has the highest $\mathrm{Zr}(>400 \mathrm{ppm}), \mathrm{Nb}(>20$ ppm), and lowest $\mathrm{Sr}(<60 \mathrm{ppm})$ content of all the Dinner Creek Tuff units.

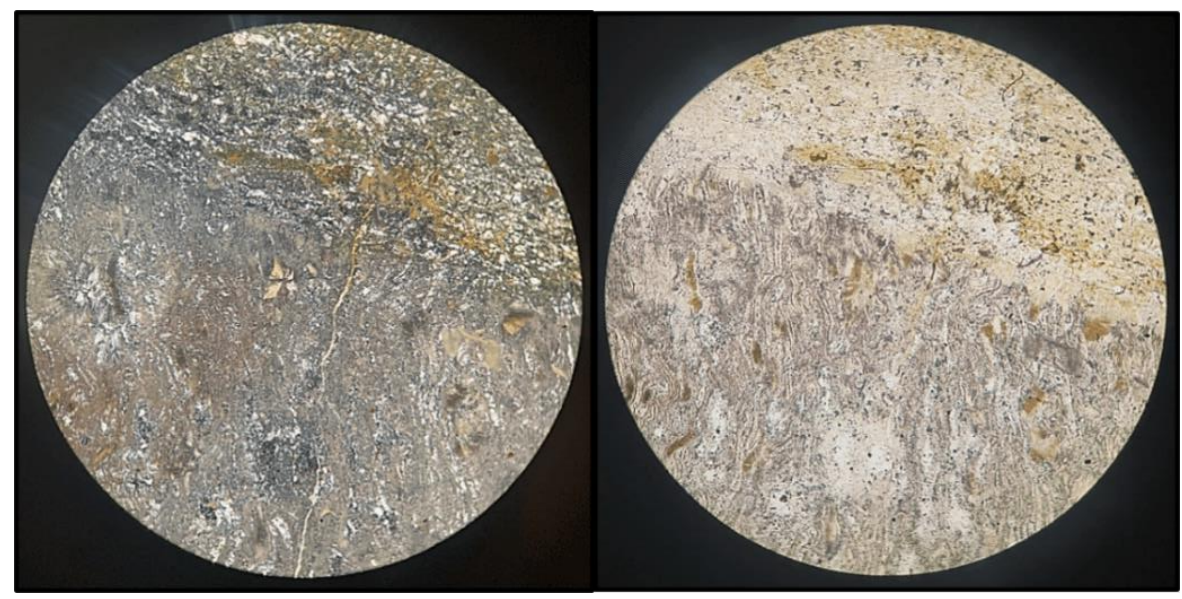

Figure 26: Thin section image of Dinner Creek unit 1 (sample BC19A61). The images display a glassy (ash) matrix. The left image is in XPL, with the right being taken in PPL. Images are in 100X optical zoom.

\subsubsection{LOCAL to REGIONAL BASALTS}

I. Tpvd - Near Vent Pyroclastic Deposits, Basalt to Basaltic Andesite of the Strawberry Volcanics

This unit is made up of near-vent mafic pyroclastic fall and flow deposits. Vent facies of Tpvd includes scattered strombolian deposits consisting of highly vesiculated lapilli to bomb-sized pyroclasts, often red or dark grey in color. Mafic bombs and spindle bombs were often abundantly found as float surrounding outcrops. Outcrops contain lithic fragments of aphyric andesite. Stratigraphically overlies the Dinner Creek Tuff units, having a maximum 
age of 15.5 Ma. Exposures are typically between approximately 3-10m in height. The largest outcrop is found in the northernmost-central region of the BC quad near Juniper Springs (Figure 27 and Figure 28), with dipped beds reaching 40m thick and surrounded by the andesite of the Strawberry Volcanics.

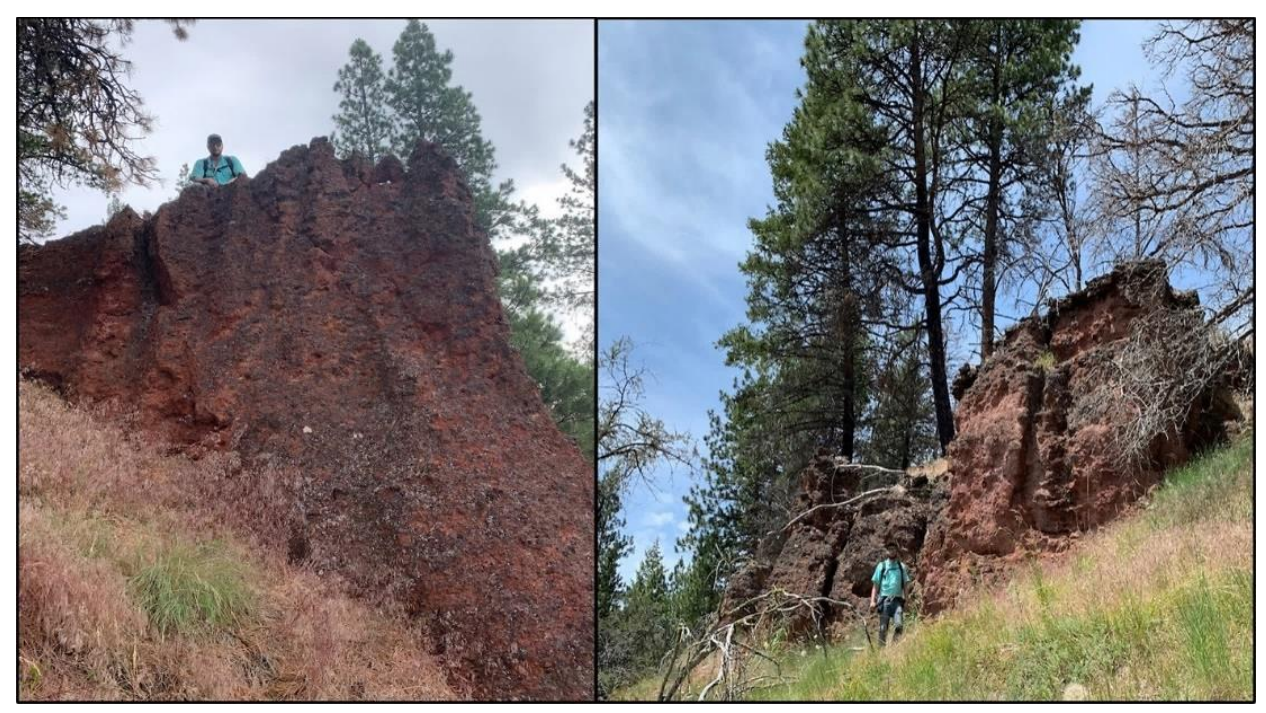

Figure 27: Photograph looking at a sizeable basaltic-andesite outcrop in the BC map's northernmost-central region (sample BC19B07).

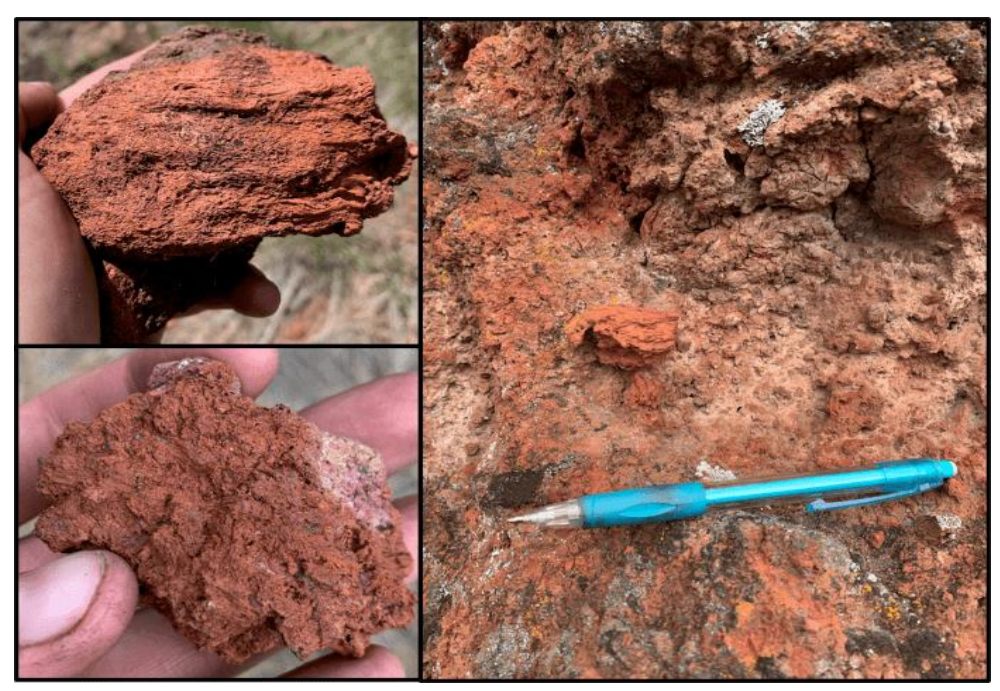

Figure 28: Close-up look at the basaltic andesite outcrop (Sample BC19B07). Highly vesiculated red basaltic andesitic scoria consisting of fine lapilli occasional coarse ash and featuring spindle bombs around and protruding out of the outcrop. 


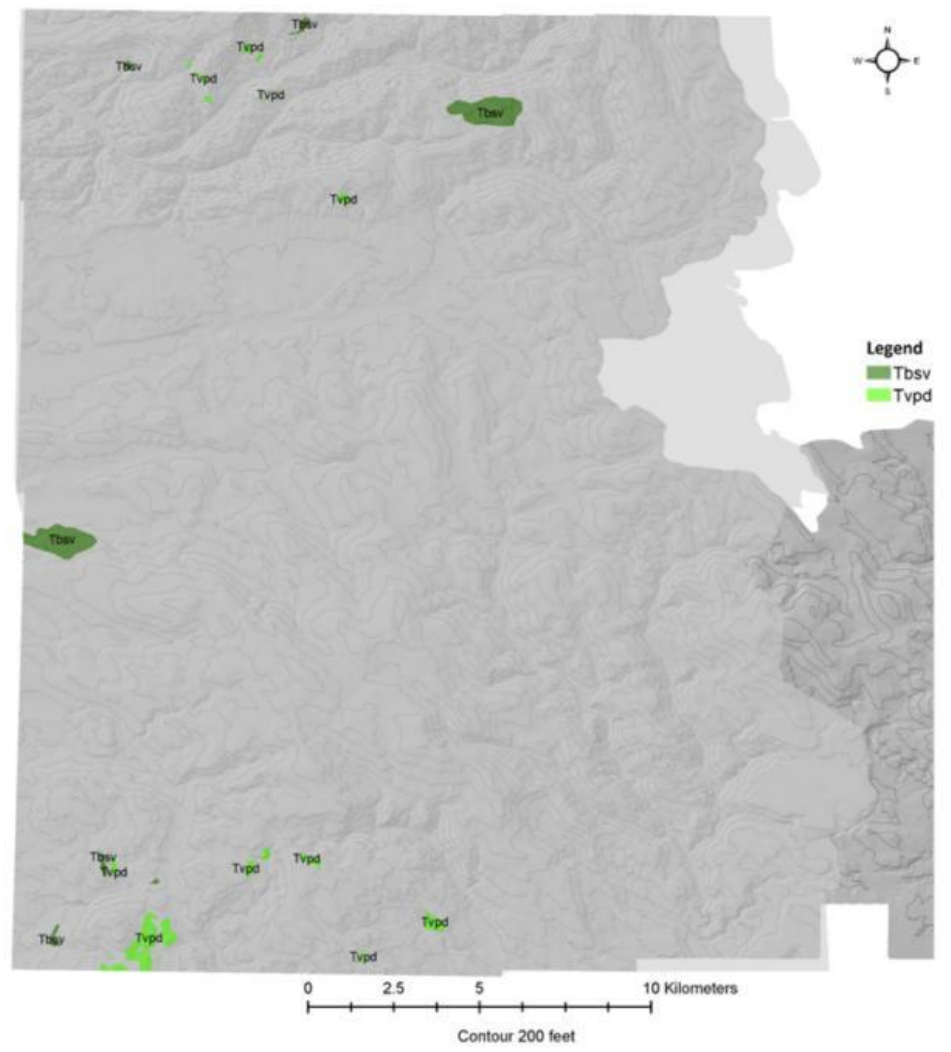

Figure 29: Distribution of the units Tpvd (light green) and Tbsv (dark green) across the entire mapping area with other units greyed out.

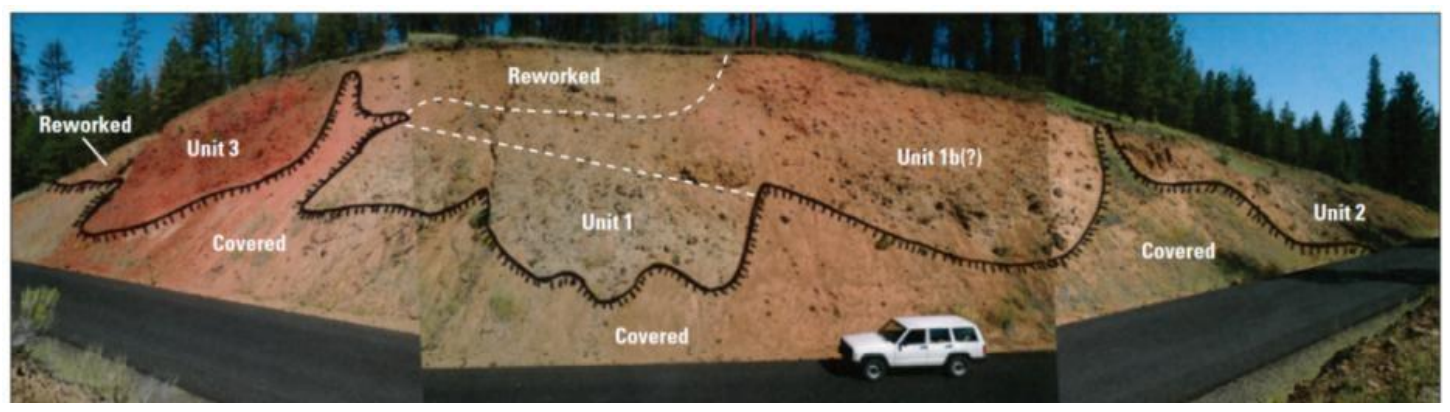

Figure 30: Photograph looking north at mafic pyroclastic flow, unit Tvpd makes up units 1 and $1 \mathrm{~b}$ in the image. Image label unit 2 and scoria fall deposits (unit 3) make up the flow of the pahoehoe toe. "Covered" means talus conceals outcrop; the black line is the upper extent of the talus. "Reworked" means the unit is slightly modified from subsequent processes. The dashed white line is the presumed contact between units. Photograph by Martin Streck. (Ferns, et al., 2017). 


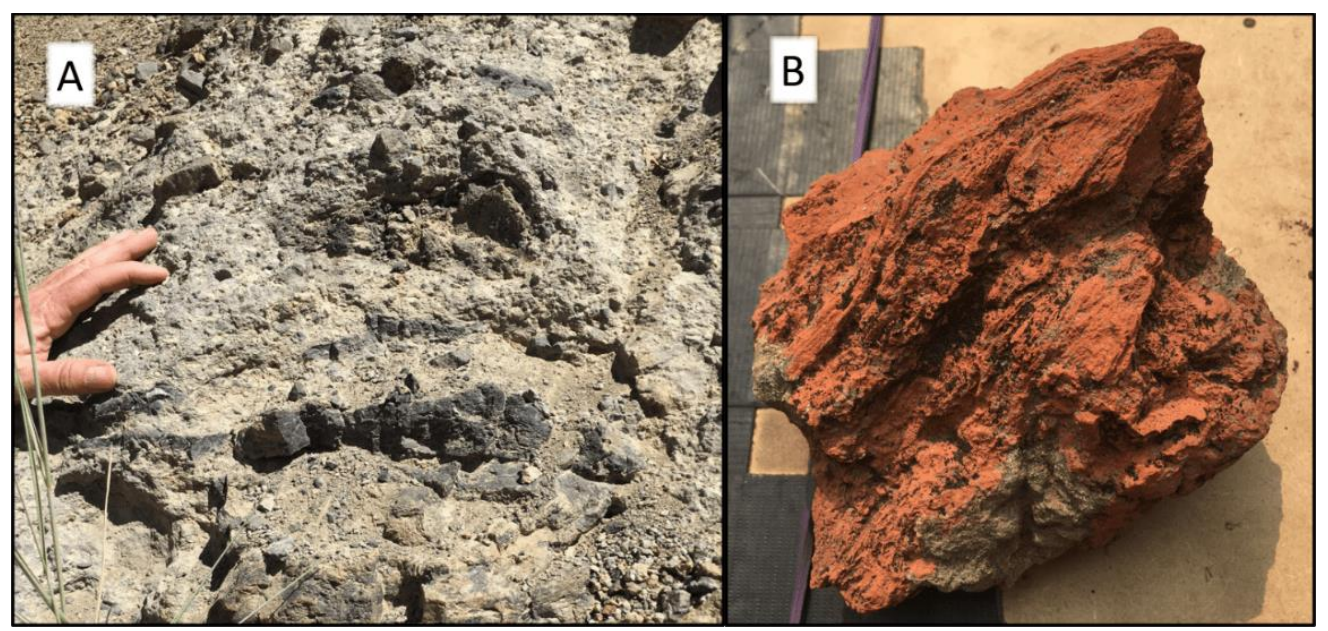

Figure 31: (A) Outcrop of Tpvd (named Tbt in JOJM quad) in roadcut along NF17, icelandite juvenile clasts are pictured. (B) Spindle bomb.

Figure 30 illustrates one roadcut exposure in the JOJM quad, where Tpvd is not only strombolian deposits but also includes what appears to be proximal flow deposits and is named Tbt in the JOJM 7.5 min mapped quadrangle from 2018. The dark scoria throughout the entire outcrop of Figure 30 is icelandite. More details of this outcrop are found in Ferns et al. (2017). Mafic pyroclastic fragments are phenocryst poor and contain less than $8 \%$ phenocryst, mainly consisting of plagioclase, minor olivine, and rare pyroxene. 


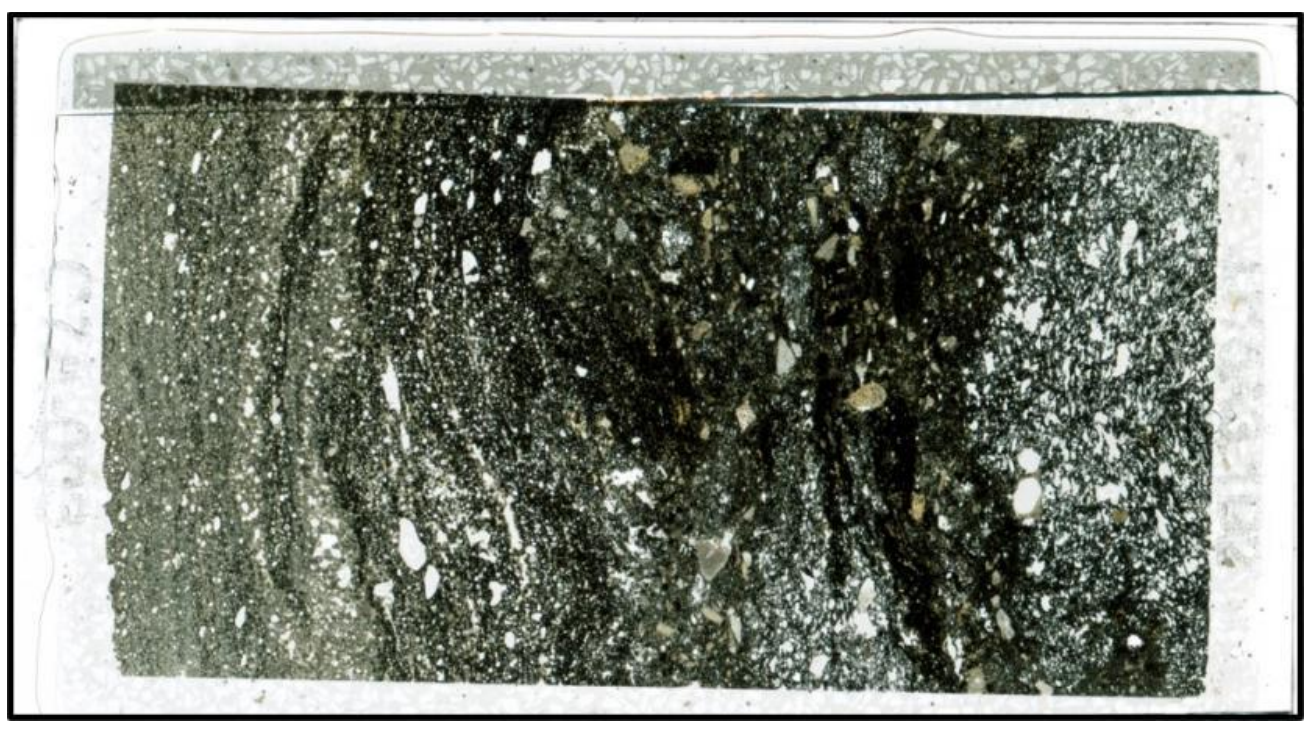

Figure 32: Pictured is a full thin section image of sample JJ18A3.1D2. The unit is abbreviated as Tbt in JOJM 7.5 min quadrangle from 2018. This thin section is in PPL and showing a glassy matrix containing lithics and is vesicle rich.

\section{Tbsv - Basalt to Basaltic Andesite Lavas of Strawberry Volcanics (Miocene)}

Outcrops of Tbsv are, in general, found scattered throughout the JOJM and BC quadrangles. Small outcrops are found in the far southwestern corner of JOJM. The larger outcrop of Tbsv in JOJM is in the northwestern region of the quad. The largest area of Tbsv is found in the northeast of the $\mathrm{BC}$ quad. There is a small exposure in the northwest section of $\mathrm{BC}$ that overlies sandstones of the accreted terrane. Outcrops or float are typically massive. Lavas are intercalated with Tasv and are rarely mappable. Hand samples are coarsely grained, dark-colored, and range from dense to vesiculated. The coarse-grained basalt to basaltic andesite is highly crystalline but phenocryst poor with olivine phenocrysts observable in the 
hand sample and sometimes a few plagioclase phenocrysts. Observable olivine phenocrysts in hand samples were used to map lavas as basalt to basaltic andesite.

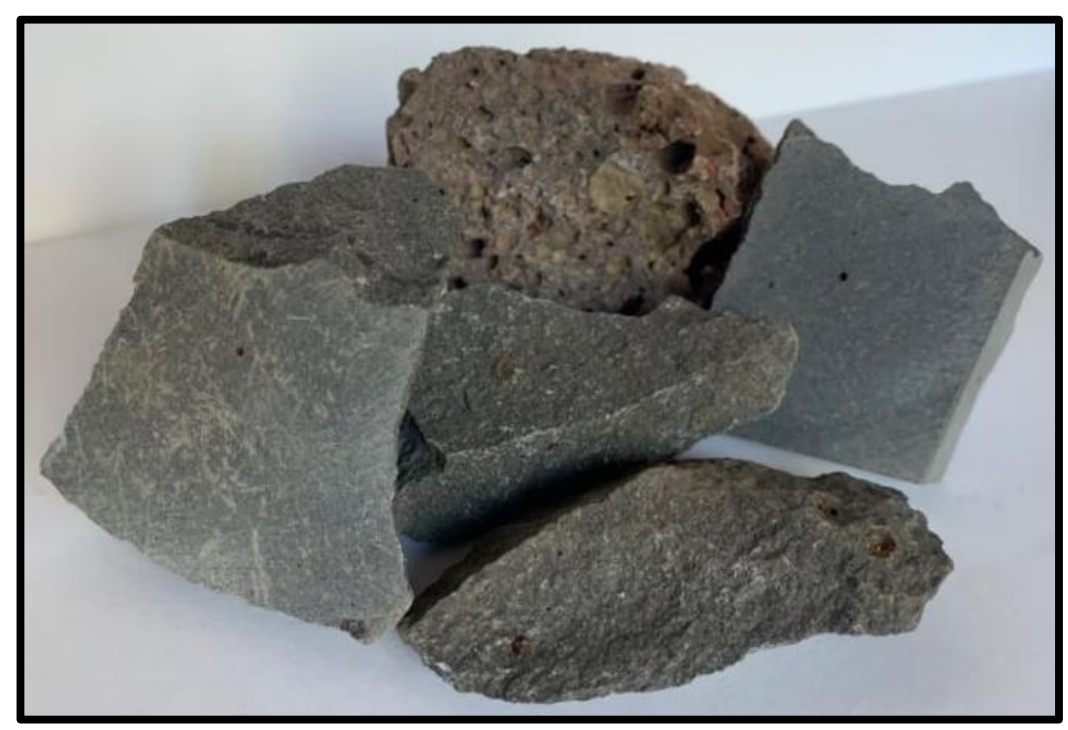

Figure 33: Basalt of the Strawberry Volcanics, sample BC19B36 in hand sample.

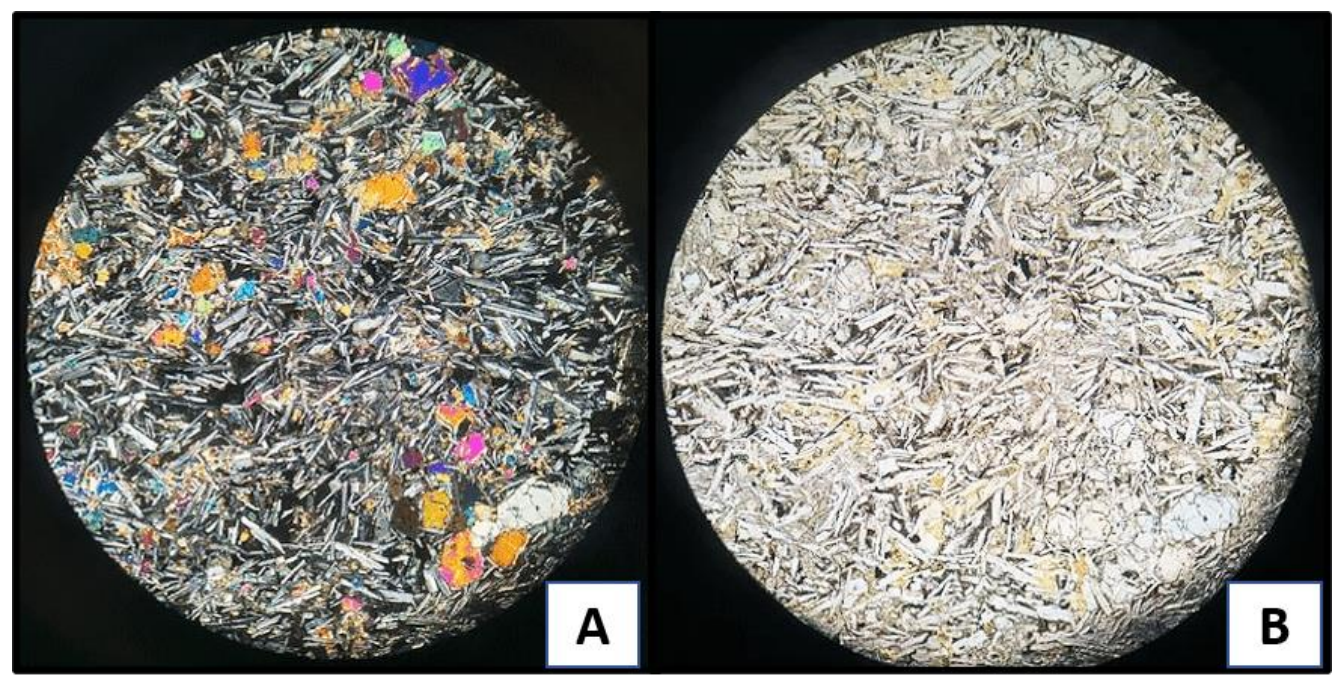

Figure 34: Basalt of the Strawberry Volcanics, sample BC19B36 in thin section. Image A is in XPL, B is in PPL, 40X optical zoom. 
In thin section, olivine phenocrysts make up $\sim 5 \%$, and the texture is intergranular. The groundmass comprises coarse plagioclase laths with interstitial pyroxene. The coarse groundmass has no preferred alignment. Groundmass under 400X magnification and PPL conditions indicate abundant yellowish to vibrant interference colors suggesting mafic interstitial silicates are orthopyroxene and augite. One sample of basaltic andesite lava has a silica content of about 53 wt. $\%$ and a $\mathrm{FeO}^{*}$ content of 9.23 wt. $\%$. The sample contains a few large olivine phenocrysts within a microcrystalline groundmass primarily made up of plagioclase with some olivine and pyroxene (Figure 34). Hence, samples of Tbsv have a silica range of about 50 to 53 wt. $\% \mathrm{SiO}_{2}$ (Figure 35).

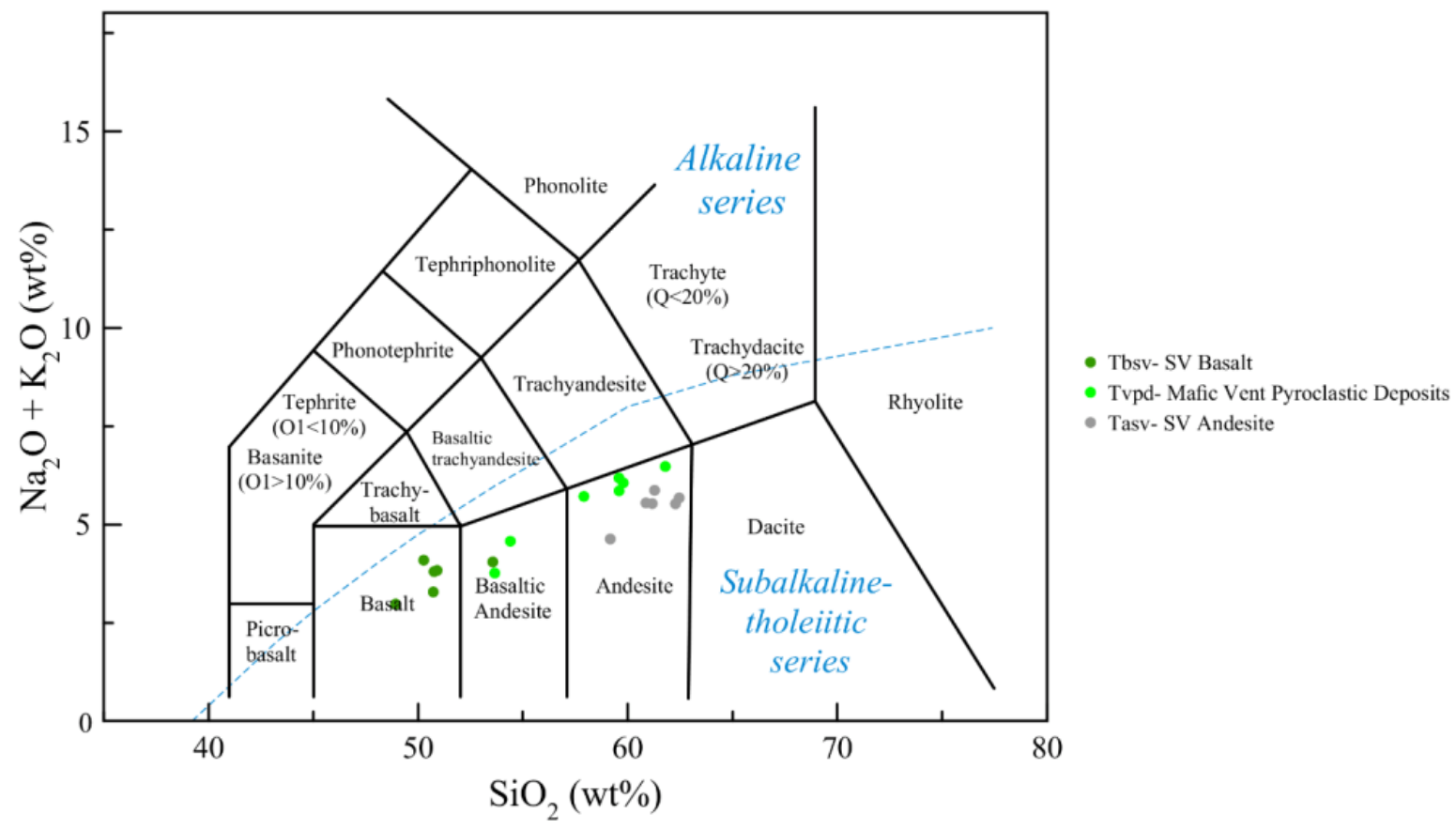

Figure 35: Total alkali-silica classification diagram displaying the samples of basaltic to andesitic compositions from this project. 


\subsubsection{INTERMEDIATE STRAWBERRY VOLCANICS}

I. Tasv - Andesite of Strawberry Volcanics (16-12 Ma)

The andesite of the Strawberry Volcanics comprises lavas of andesitic compositions exposed throughout the entire project area. This unit includes intercalated unmappable (only sparsely distinguished or exposed in the field) basalt to basaltic andesite lavas of Tbsv. Outcrops are often platy, blocky, or smooth with conchoidal fracturing in habit with very thin plates to massive. Tasv often appears aphyric, but phenocryst content varies from aphyric to $\sim 12 \%$. The groundmass is defined as a very fine sugary matrix of plagioclase with little pyroxene. Plagioclase and ortho-and clinopyroxene dominate the phenocrysts in the Tasv unit. Aphyric andesite is the dominant rock lithology of Tasv of the main sequence of the southern part of the Strawberry volcanic field (Steiner and Streck, 2013). Tasv lavas occur above the oldest rhyolite of the area but are intercalated with the younger rhyolites of the Strawberry Volcanics. Analyzed samples of Tasv have a range of $\mathrm{SiO}_{2}$ from 58 to 62 wt. \% (Figure 35) and $\mathrm{Zr}$ content of 148 to $168 \mathrm{ppm}$. Tasv lavas are typically southward dipping at an angle of $\sim 10$ degrees, and this has been observed in the region south of Strawberry Mountain. In the northern-central region of the $\mathrm{BC}$ quad, an andesite dike was discovered. In the hand sample, the dike shows elongated vesicles as well as a hypabyssal texture. The andesite dike in the outcrop has near-horizontal columnar jointing and overall is about $8 \mathrm{~m}$ wide by $15 \mathrm{~m}$ long. Image A in Figure 36 is of the andesite dike outcrop located within the BC quad. 


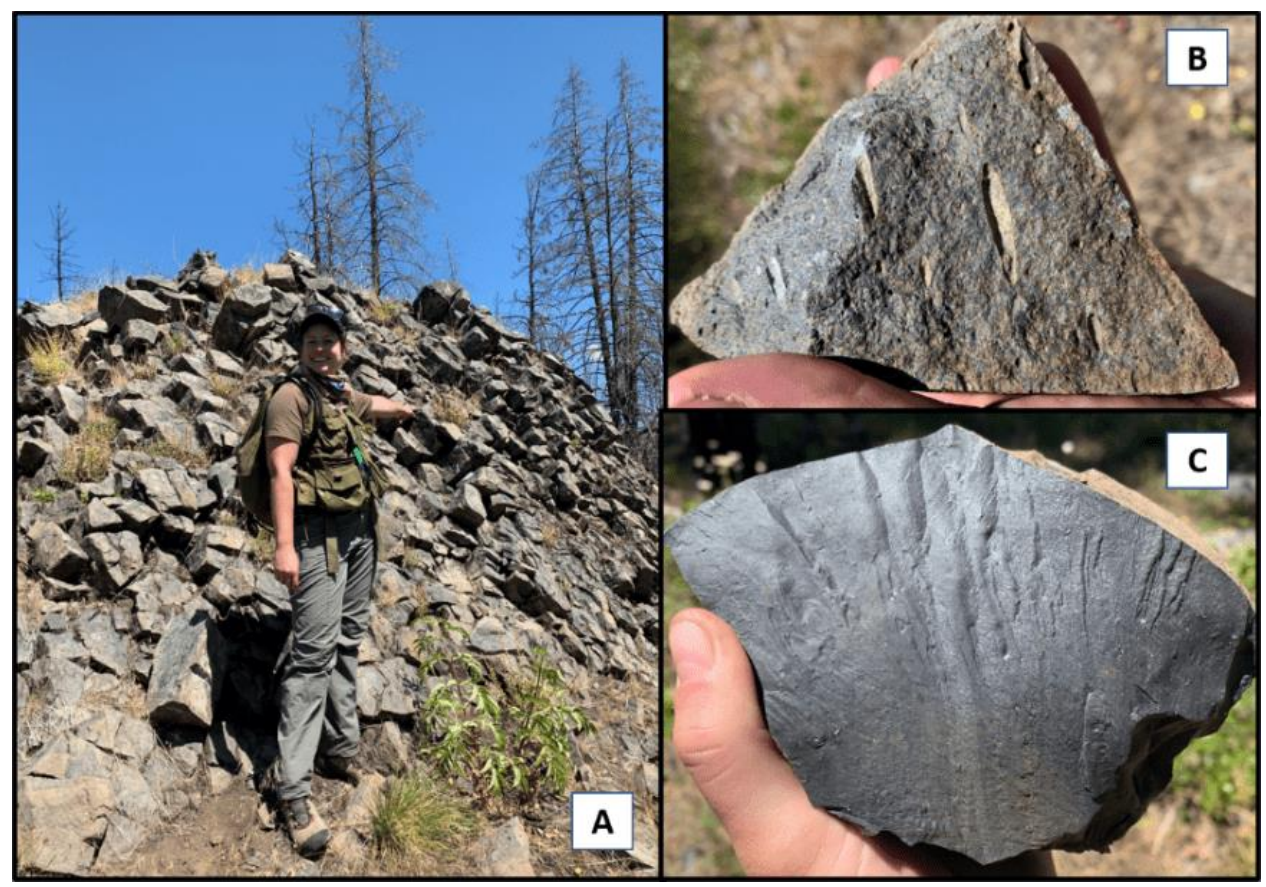

Figure 36: Photograph (A) is an andesite dike (sample BC19B45), with image B representing the dike in hand sample. Image $\mathrm{C}$ is from sample BC19A22 displaying a distinct lithological variant of Tasv that is fine-grained, black, and fractures conchoidally.

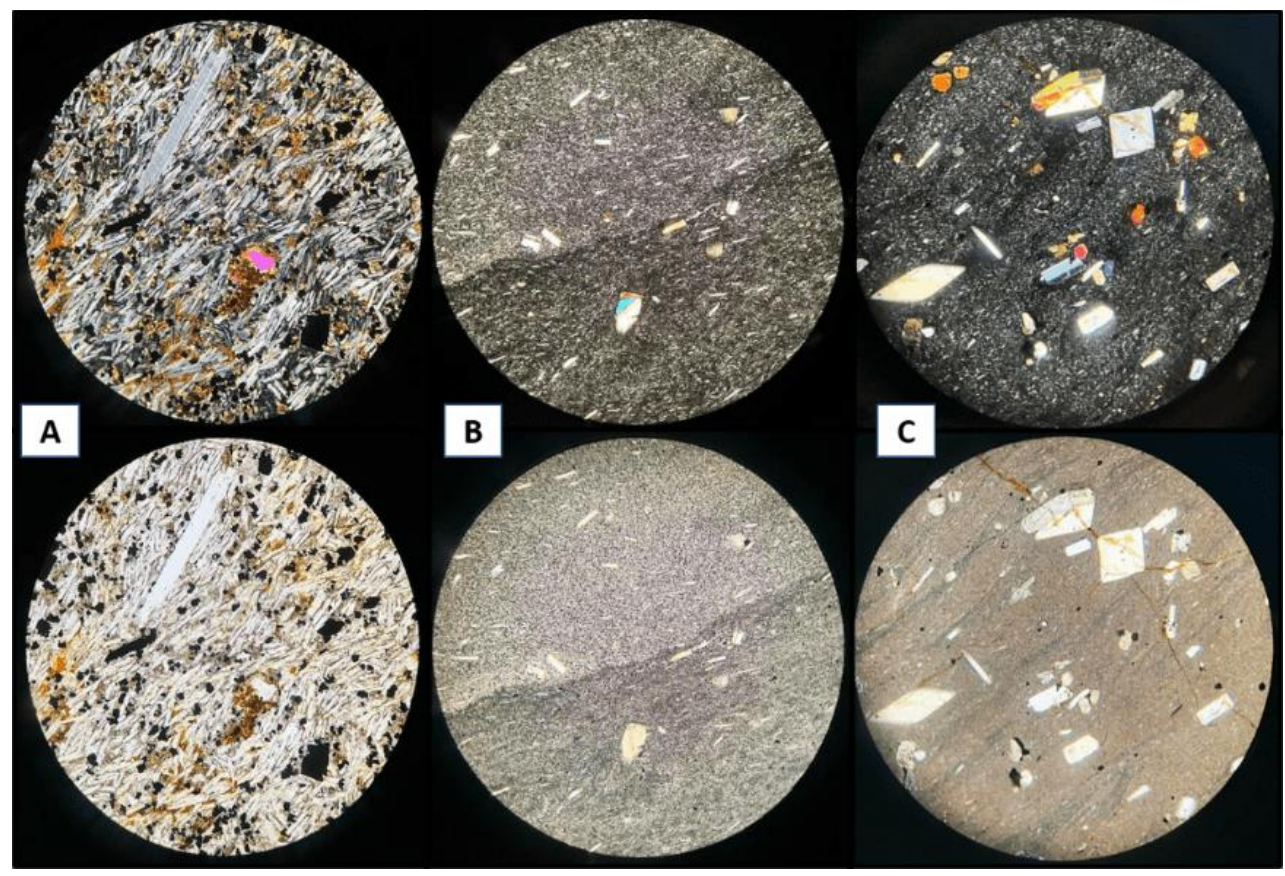

Figure 37: Sample numbers and optical zoom are as follows - (A) BC19A50 (100X), (B) BC19A22 (40X), (C) BC19C69 (40X). The top half of the photograph's thin sections are in XPL, with the bottom half in PPL. 
One distinctive facies of Tasv is 'black' andesite exhibiting conchoidal fractures that make it almost appear to be glassy (image C of Figure 37). Groundmass crystals are very small and only discernible in thin sections (sample BC19A22, image B in Figure 37). The more typical Tasv (image A in Figure 37) contains $<1-10 \%$ plagioclase phenocrysts with $<1 \mathrm{~mm}$ in size set in a sugary groundmass.

\section{Ttms - Tuff of Milk Spring (Mid-Miocene)}

The tuff of Milk Spring is composed of different pyroclastic deposits. This unit stratigraphically overlies the rhyolite of Canyon Creek in the north-eastern region of the BC quadrangle and just below the Rhyolite of Buckhorn Spring. The unit Ttms also crops out in the southern region of JOJM and on the southwestern margin of MPT. The tuff of Milk Spring also sporadically occurs in the northwestern end of the LVW quad. The largest outcrop of the tuff of Milk Spring is located off NF909, just south of Milk Spring at the coordinates (44.034, -118.805). Overall, this unit is white to light grey in color and has a thickness range from 5 to $30 \mathrm{~m}$. The depositional settings for Ttms are comprised of fallout, ash-flows, and surges, the latter of which was made up of several events. Its massive member overlies the stratified surge deposits. The observed lithics in all the lithological deposits of Ttms range from lapilli to bomb size (up to $0.5 \mathrm{~m}$ ) and contain all the Dinner Creek Tuff units, rhyolites of the Strawberry Volcanics, obsidian, and andesite lithologies. Juvenile components of Ttms consist of glass shards, vesiculated pumice shards, and lapilli to bomb-sized pumices. The groundmass is finegrained and non-porphyritic, and the color is light brownish gray with black to brown clasts. 


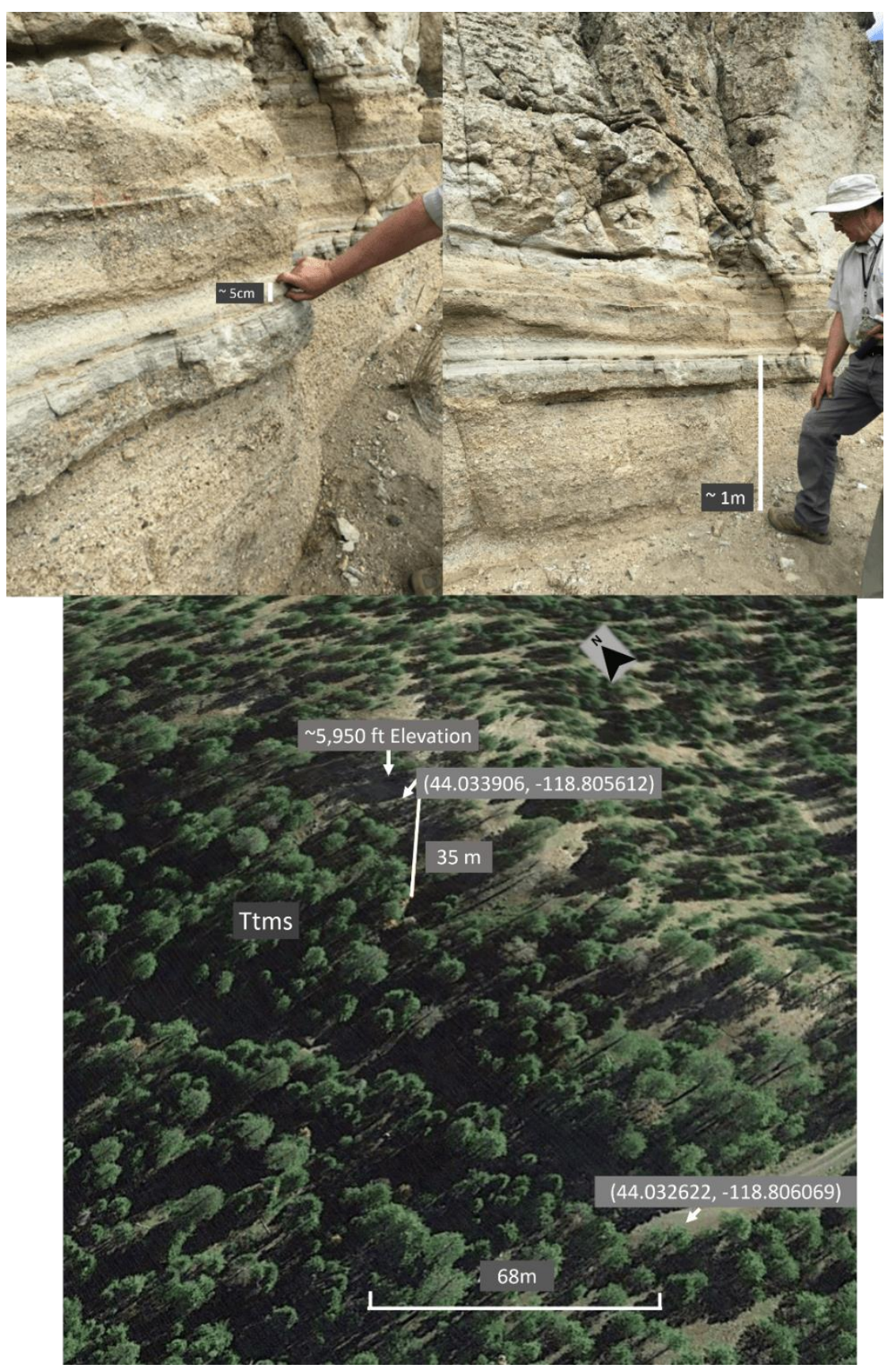

Figure 38: The first image on the upper left is a finely stratified tuff of Milk Spring consisting of the surge and fallout deposits. The hand in the image measures a section of about $5 \mathrm{~cm}$ thick. The image on the upper right is the outcrop used in the thickness model image found at the bottom of this figure. The bottom image was generated using Google Earth and knowledge of this field location in the JOJM quadrangle. Ttms outcrop in this location measures about $35 \mathrm{~m}$ in thickness. 


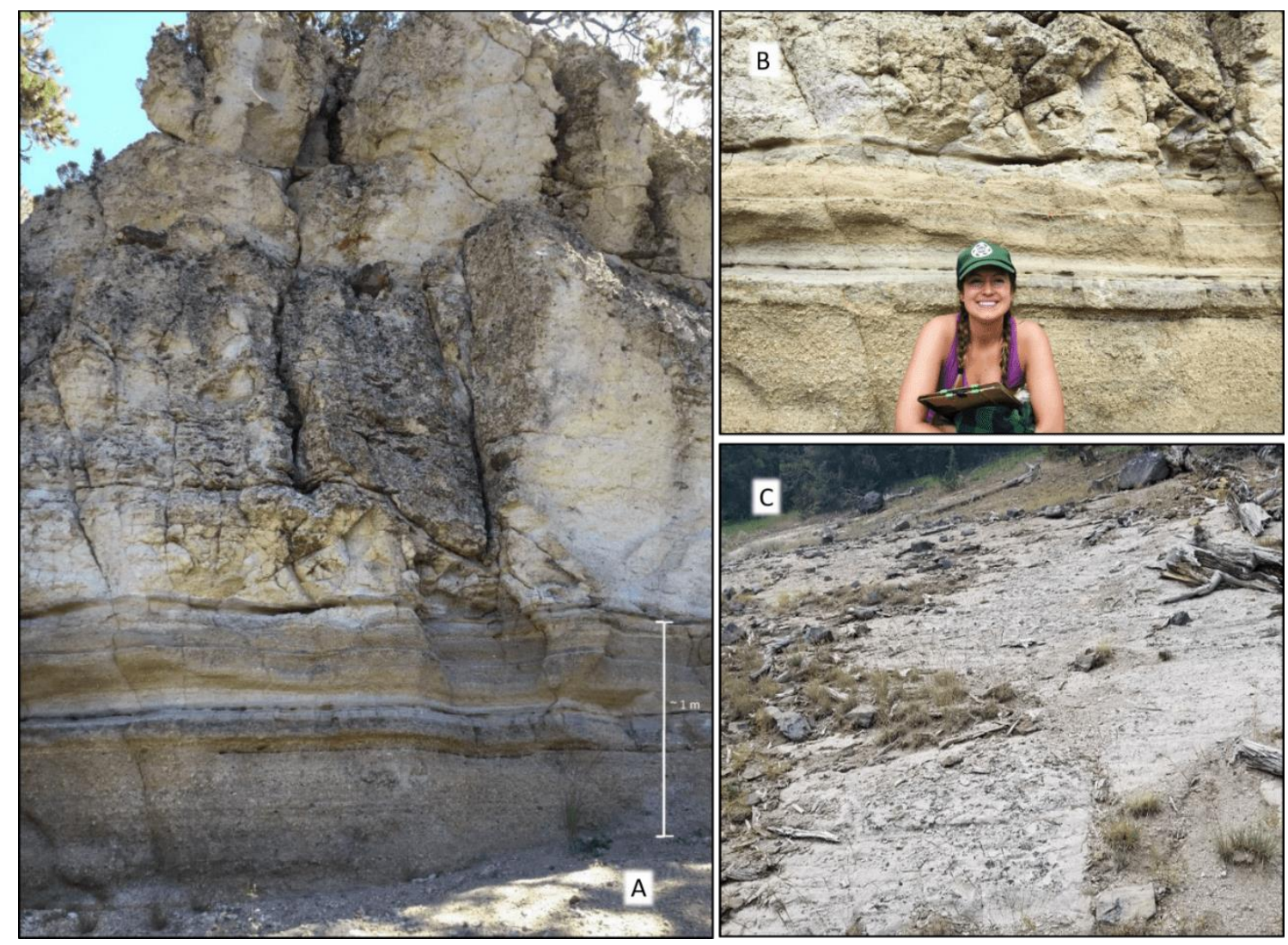

Figure 39: (A)-(B) Milk Spring Tuff of the south-central region of the Jump-off Joe Mountain quadrangle. The basal surge and fallout deposits are about $1 \mathrm{~m}$ thick and overlain by an ignimbrite incorporating larger lithics. (C) Fallout tuff and surge deposit in a nearby section of the Milk Spring Tuff.

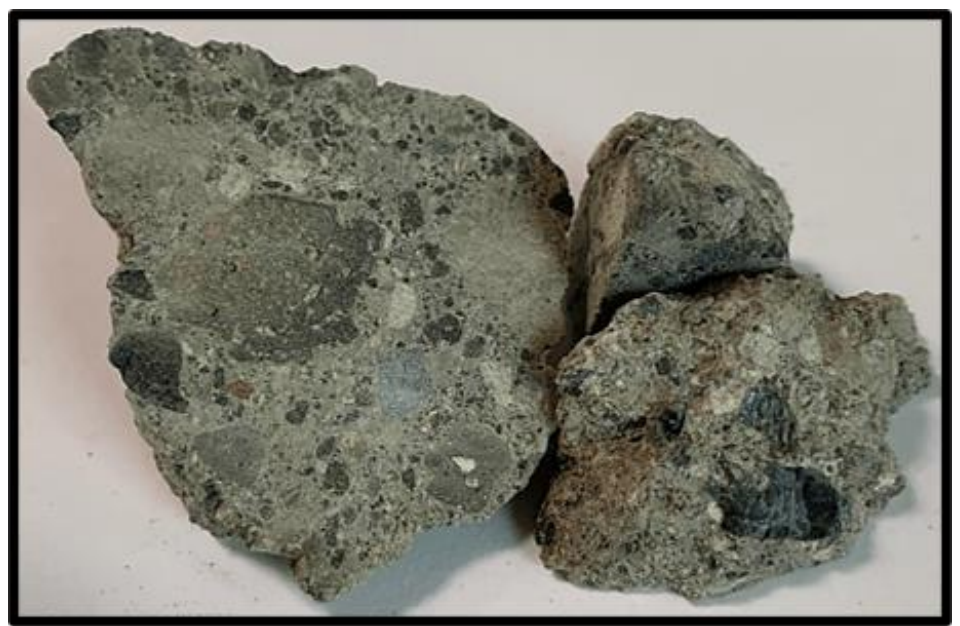

Figure 40: Milk Spring Tuff in hand sample BC19C56 displays lithics made up of multiple units. 
The lower stratified surge deposits are thinly bedded, consisting of ash to bomb-sized pumices, smaller lithics. The surge deposits contain visible pumices and Strawberry andesite lithics in the hand sample, along with some large clasts of Dinner Creek Tuff unit 1. The estimated area for Ttms in the region is $\sim 140 \mathrm{~km}^{2}$. The most evolved component of the Milk Spring Tuff is pumice clast of rhyolitic composition. However, bulk samples of the ignimbrite typically straddle the andesite/dacite transition with $\mathrm{SiO}_{2}$ contents of $\sim 61$ to 64 wt. $\%$ and are iron-rich, ranging from 6.6 to $7.7 \mathrm{wt} . \% \mathrm{FeO}$. In the thin section, the groundmass is primarily glass with some groundmass plagioclase laths. Ttms comprises about $\sim 5 \%$ plagioclase phenocrysts, glass, and seldom anhedral amphibole phenocrysts.

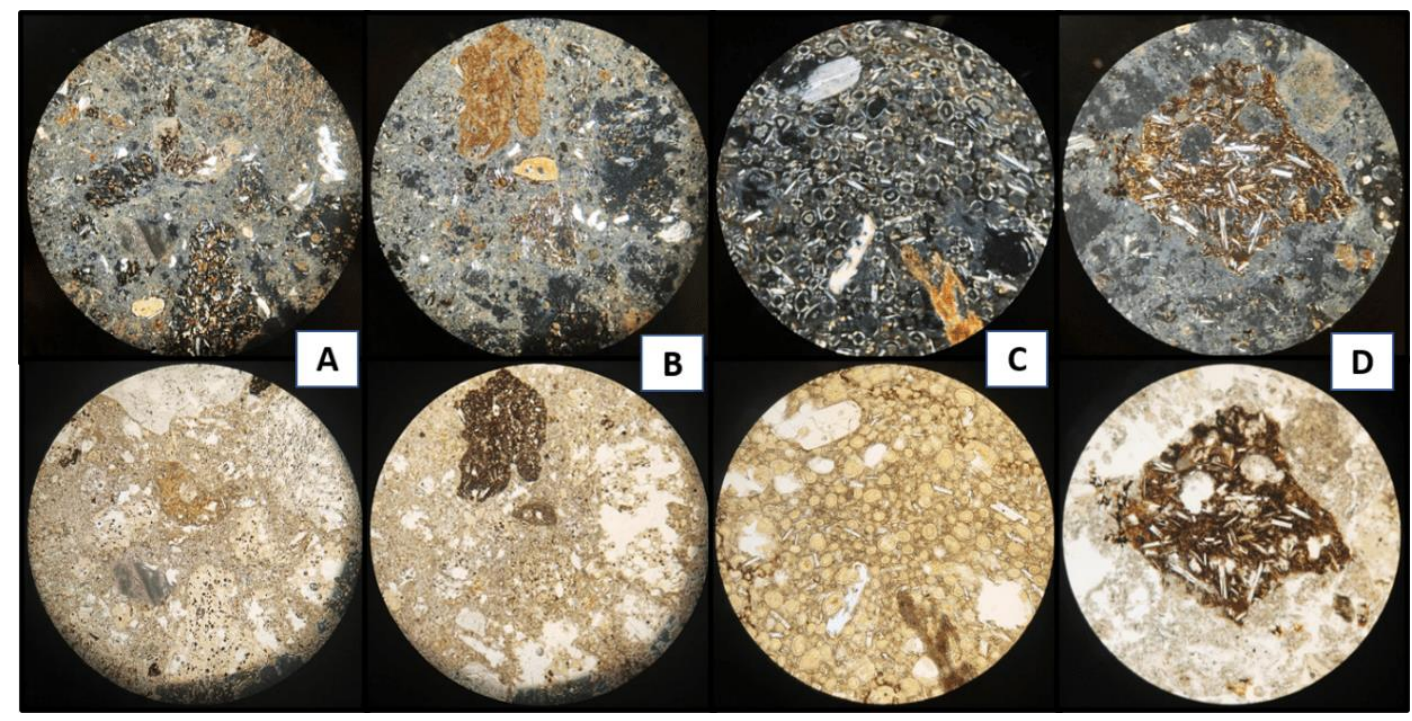

Figure 41: Milk Spring Tuff in thin section, XPL on top with PPL images on the bottom. Note prominent lithic fragments in $\mathrm{B}$ and $\mathrm{C}$ with lithologies of andesites of the Strawberry Volcanics. All images are from sample BC19C56, with A and B in 100X optical zoom. Lastly, with C and D in a 40X optical zoom. 


\section{Thsd - Holdout Spring Dacite (Oligocene)}

Holdout Spring Dacite is found as blocks in the debris flow portion of the Mullen Spring Volcanic Clastics unit (Tmus) along NF17 in the southern region of the JOJM quad, cropping out only in small regions. This unit also crops out in the north-eastern region of LVW. One sample, MS-18-02, was geochemically analyzed and best correlated with the Oligocene dacites found in the adjacent Calamity Butte quadrangle (Cruz and Streck, 2018). Calamity Butte quad lies just south of JOJM. Holdout Spring Dacite can be greenish in color and contains large plagioclase phenocrysts up to $1 \mathrm{~cm}$. The Thsd units are found in only a few outcrops confined to a small area. The estimated area for Thsd in the region is $\sim 1.4 \mathrm{~km}^{2}$. In the thin section, pseudomorphs of amphibole are present, and large crystals are visibly plucked from the cut thin section. The shape of these plucked crystals that remain suggests they were likely mostly plagioclase and hornblende.

\section{Tmus - Mullen Spring Volcanic Clastics (Mid-Miocene)}

Tmus crops out solely along NF17 in the southern region of the JOJM quad. This unit occurs in two depositional variants primary volcanic block and ash flow and reworked debris flow. Overall, this unit appears to be roughly the same age as the rhyolites of the Strawberry Volcanic. 


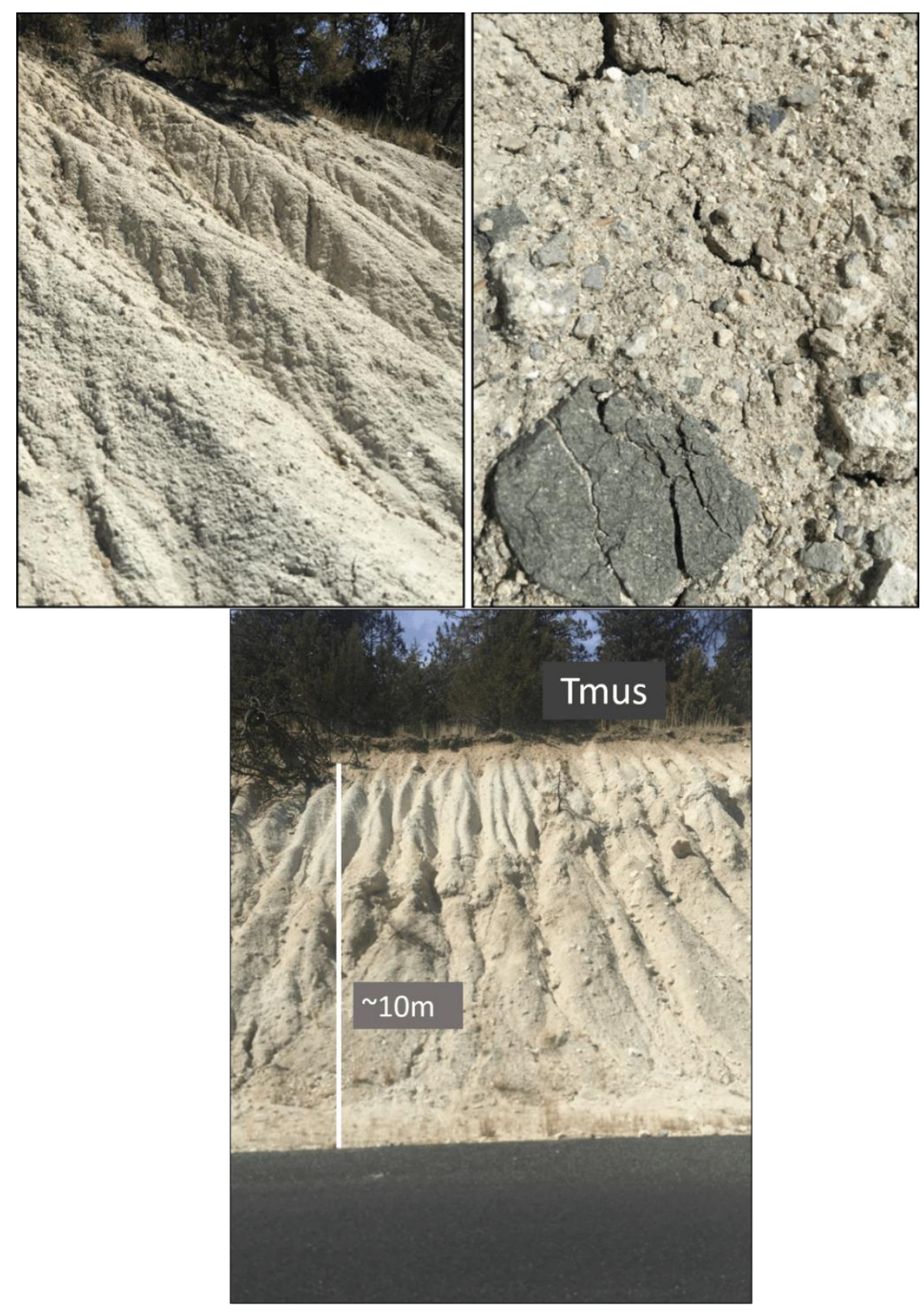

Figure 42: Left upper image is of the fine-grained epiclastic debris flow member in outcrop off NF17. The right image is a close-up image of this unit's block and ash flow member, the Mullen Spring Volcanic Clastics. The lower image is the same outcrop but detailing its unit thickness. 
The block and ash flow tuff are light grey to cream in color and unconsolidated in outcrop, ranging in thickness from 8-20 m. The blocks that are within this flow unit are compositionally dacite and rhyolite. The dacite blocks are crystal-rich, containing plagioclase, where the rhyolite blocks are crystal poor. The dacite clasts belong to the unit Holdout Spring Dacite (Thsd), which is presumed to be late Oligocene in age. Charcoal chips have been identified in the block and ash flow deposit. The epiclastic debris flow member overlies the primary volcanic deposit. The estimated area for Tmus in the region is $\sim 7.5 \mathrm{~km}^{2}$, producing a volume estimated at $0.1 \mathrm{~km}^{3}$.

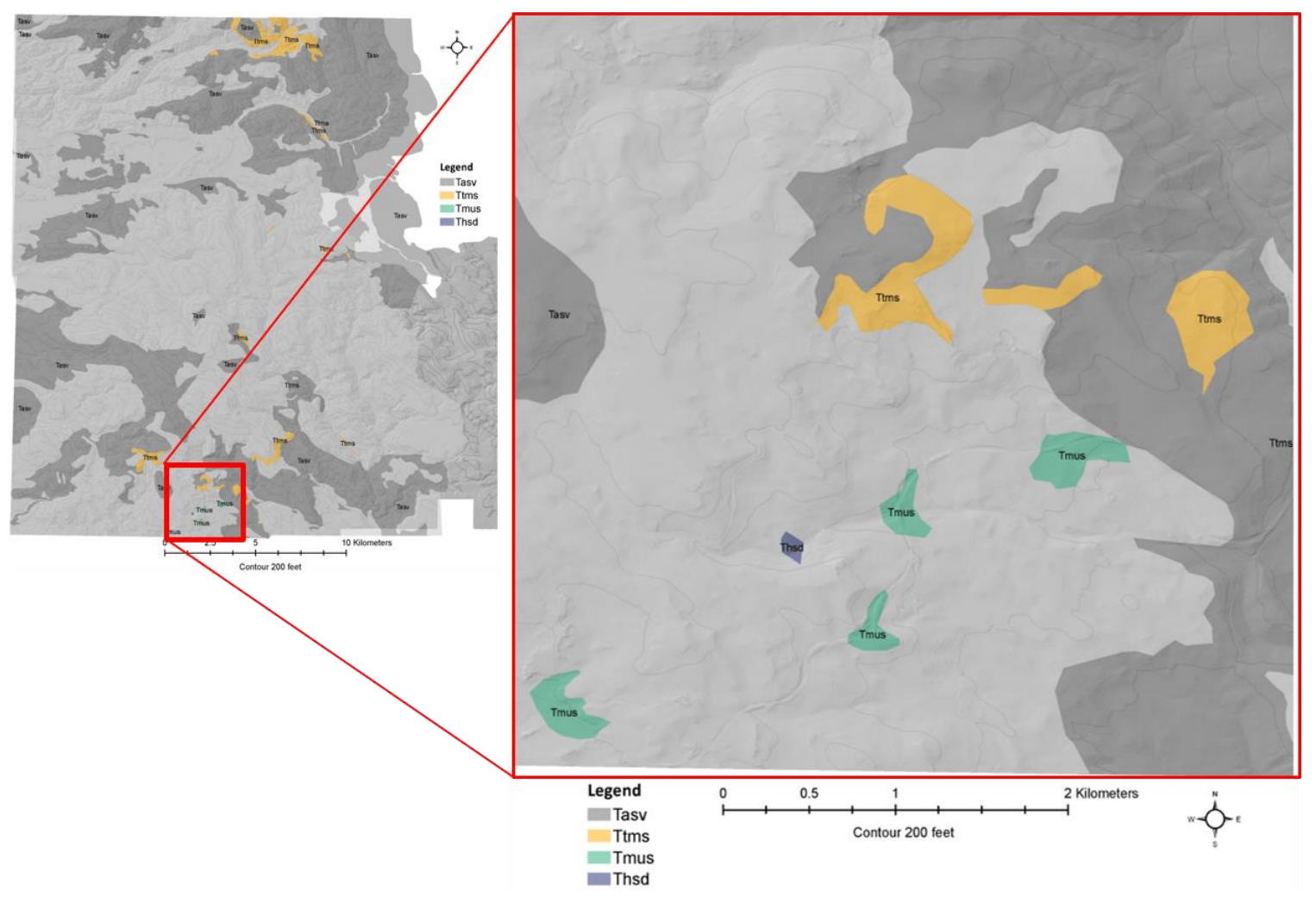

Figure 43: Geologic field map highlighting the units Tmus (pale turquoise) and the unit Thsd (purple). These units are superimposed on the entire mapped extent, with most other units greyed out, besides for Tasv and Ttms for context regarding the zoomed-in image. 
4.2 Lithology, Petrography, and Composition of the STRAWBERRY RHYOLITES 4.2.1 APHYRIC and PHENOCRYST POOR UNITS

$$
\text { I. Trtcs - Rhyolite of Three Cabin Spring (14.8 Ma) }
$$

The rhyolite of Three Cabin Spring is observed in two facies, an obsidian member and a devitrified member. These two members are often found in close proximity to one another, and both members contain virtually no phenocrysts. The devitrified portion is typically fine-grained and light grey to cream in color. The glassy member is always dense obsidian with occasional faint flow banding. The rhyolites of Three Cabin Spring in the study area were mapped and amounted to $\sim 43 \mathrm{~km} 2$, the second largest of all the Strawberry Rhyolite units. Whole-rock age dating by the ${ }^{40} \mathrm{Ar} /{ }^{39} \mathrm{Ar}$ method yielded a plateau age of $14.81 \pm 0.04 \mathrm{Ma}$ (see Appendix).

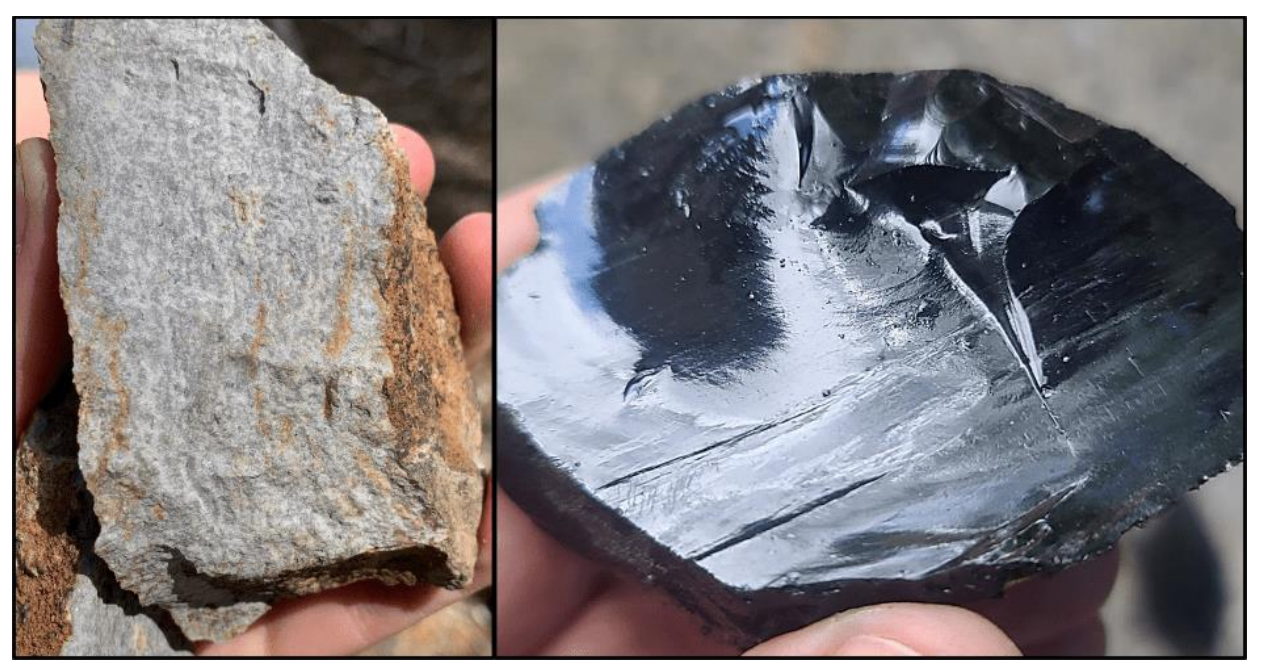

Figure 44: Hand sample images of Three Cabin Spring rhyolite sample CD1977, on the left in devitrified facies and on the right as obsidian from the LVW quad. 


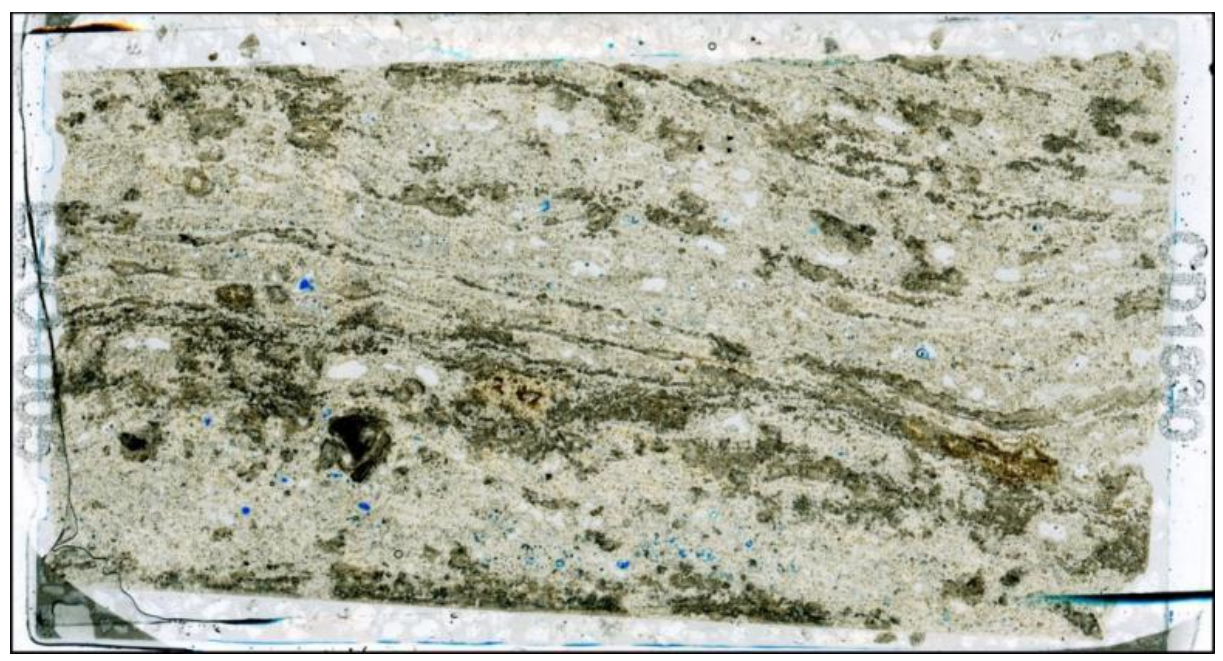

Figure 45: Thin section of a sample of devitrified Three Cabin Spring Rhyolite (Sample CD1830), with visible flow banding, in PPL.

The rhyolite of Three Cabin Spring has an average silica percentage of 77.4 wt. $\% \mathrm{SiO}_{2}$ and has an average LOI\% of 0.58 . Trtcs is lithologically comparable to Trcc but can be geochemically distinguished by $\mathrm{SiO}_{2}, \mathrm{FeO}^{*}, \mathrm{Y}, \mathrm{Zr}$, and $\mathrm{Sr}$ contents. Trtcs has an average

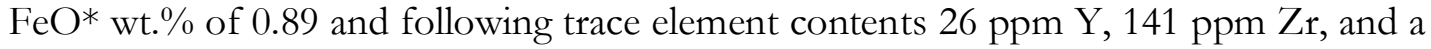
Sr value of 72 ppm. Trtcs also has a distinctly high Ba value, averaging 1403 ppm, which is higher than other SR units of this study (Figure 47). Figure 48 is a plot of $\mathrm{Nb}$ vs. $\mathrm{Zr}$ and distinguishes units in this study from being I-Type or A-Type. See Figure 49 and Figure 50 for more plots of select trace elements vs. silica contents. 


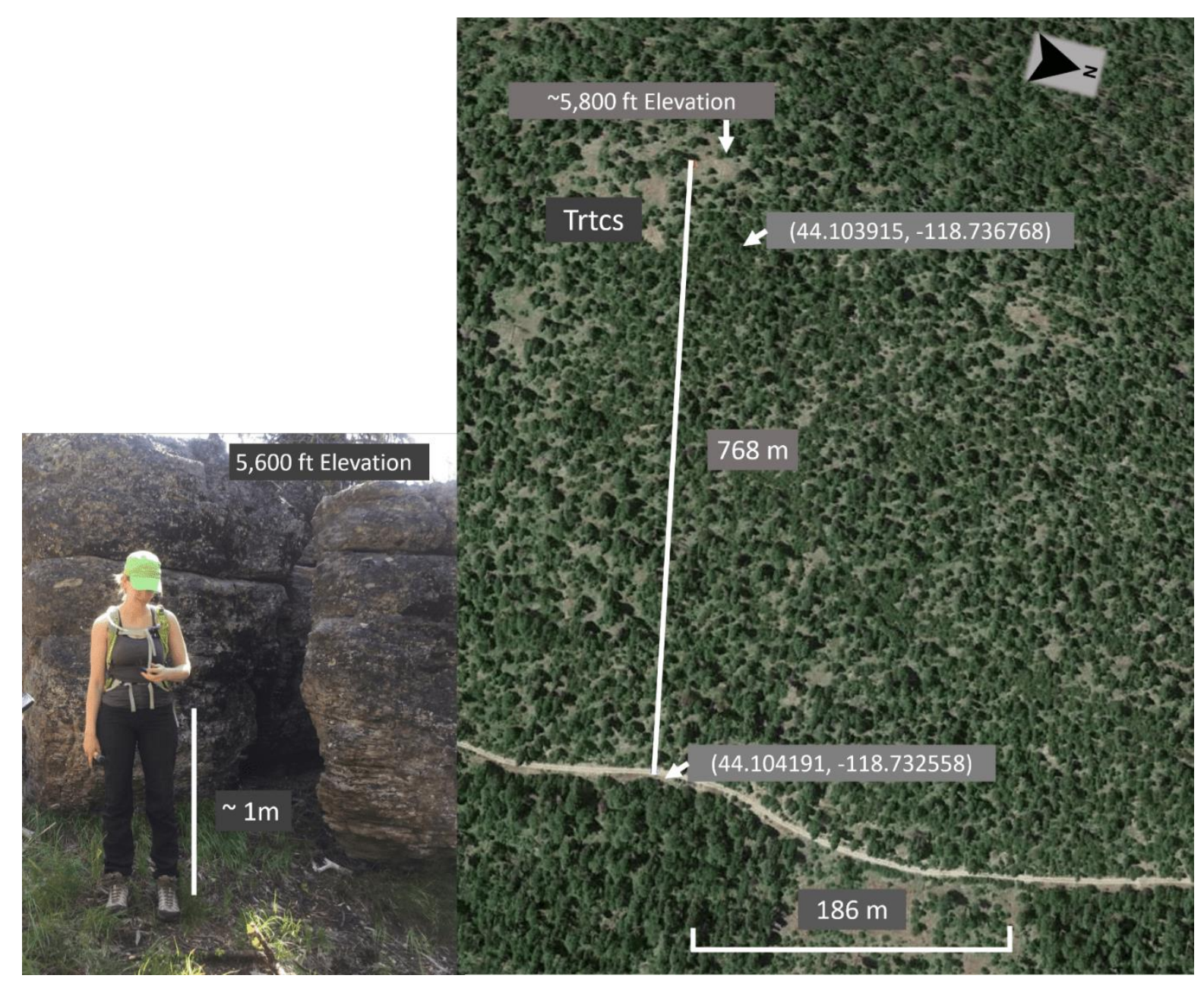

Figure 46: Photos are of the Rhyolite of Three Cabin Spring, the left image being from the JOJM quadrangle near Round Mountain where sample CD1875 was collected. The image on the right was generated using Google Earth and knowing where this unit crops out in the study area. This outcrop location is in the MPT quadrangle along the northwestern margin. Trtcs crops out in this location and covers the entire hillside stretching into its neighboring west quad of JOJM. Using this model, Trtcs unit thickness measures about $768 \mathrm{~m}$. The large size is in part a result of a fault that runs between these two locations. The fault is north-south trending and dipping to the east. A typical unit thickness will range from 40-180m. 


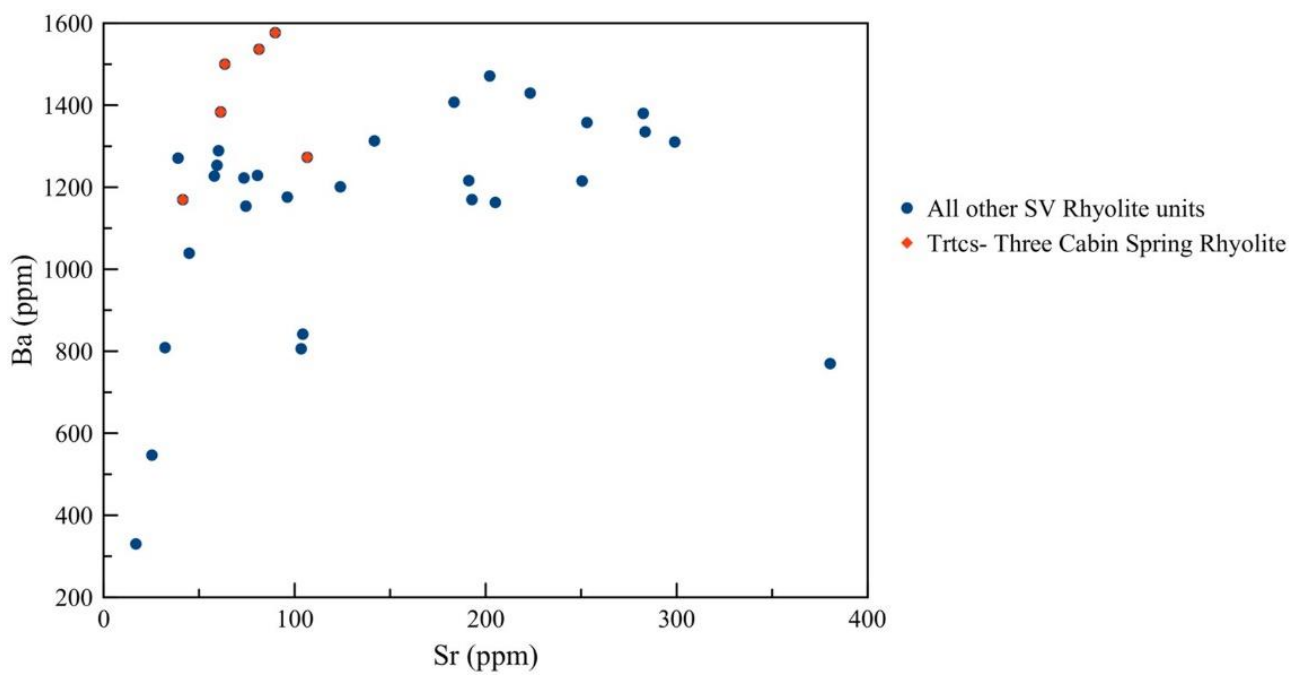

Figure 47: Ba vs. Sr variation diagram for the Strawberry Rhyolites, highlighting samples of unit Trtcs (red).

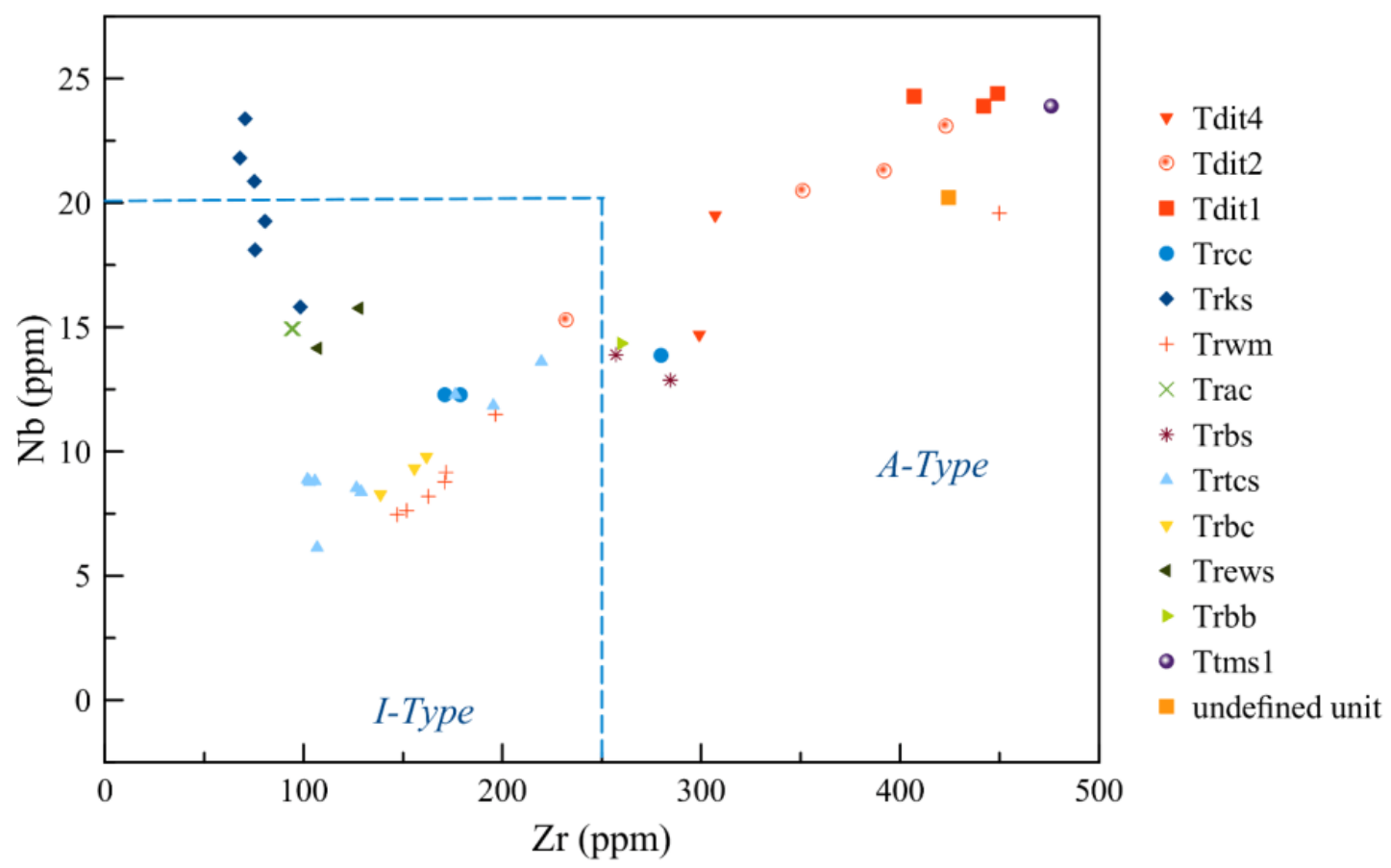

Figure 48: $\mathrm{Nb}$ vs. Zr variation diagram for the units found in this study. This plot classifies samples as I-type or A-type using the discrimination techniques of Whalen et al., 1987. The samples that plot outside the box have A-type affinities, and samples with $\mathrm{Zr}$ less than $250 \mathrm{ppm}$ and $\mathrm{Nb}$ less than $20 \mathrm{ppm}$ are classified as I-type. The coordinates of the box are $X=250, Y=20$. The undefined unit is regarding a (perlitic) rhyolite sample found in the MPT quadrangle. This has yet been defined as a discrete unit, as this map is still in progress by PSU graduate student Rachel Sweeten. 

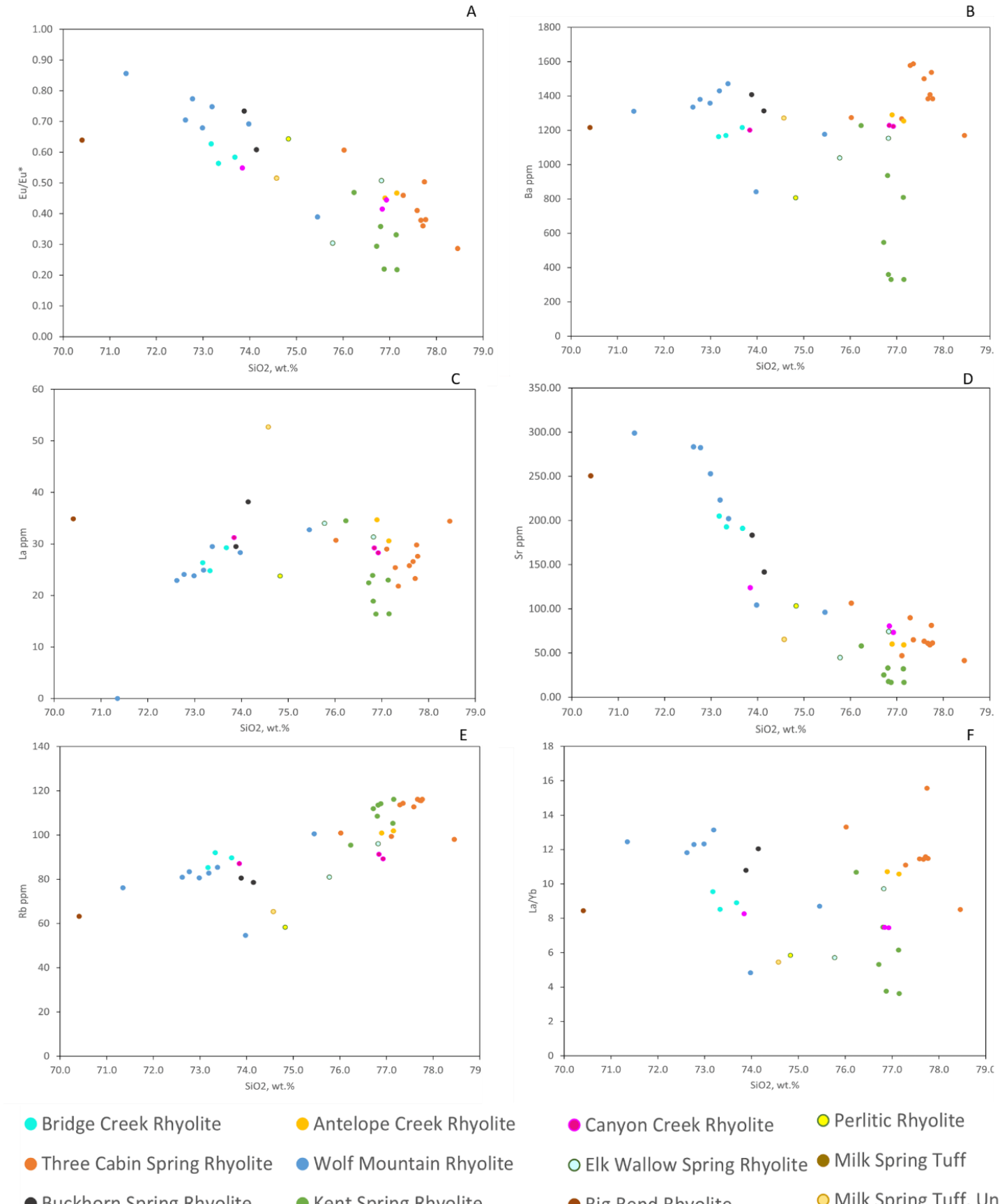

- Canyon Creek Rhyolite O Perlitic Rhyolite O Elk Wallow Spring Rhyolite Milk Spring Tuff

- Big Bend Rhyolite Milk Spring Tuff, Unit 1

Figure 49: This figure represents plots A through F (Figure 50 with plots $G$ through J) trace elements vs. $\mathrm{SiO}_{2}$ wt. \% plots for the SV rhyolites. Plot A: Eu/Eu* vs. SiO2 wt. \%. Plot B: Ba ppm vs. SiO2 wt. \%. Plot C: La ppm vs. SiO2 wt. \%. Plot D: Sr ppm vs. SiO2 wt. \%. Plot E: Rb ppm vs. SiO2 wt. \%. Lastly, Plot F: the ratio $\mathrm{La} / \mathrm{Yb}$ ppm vs. SiO2 wt. \%. 

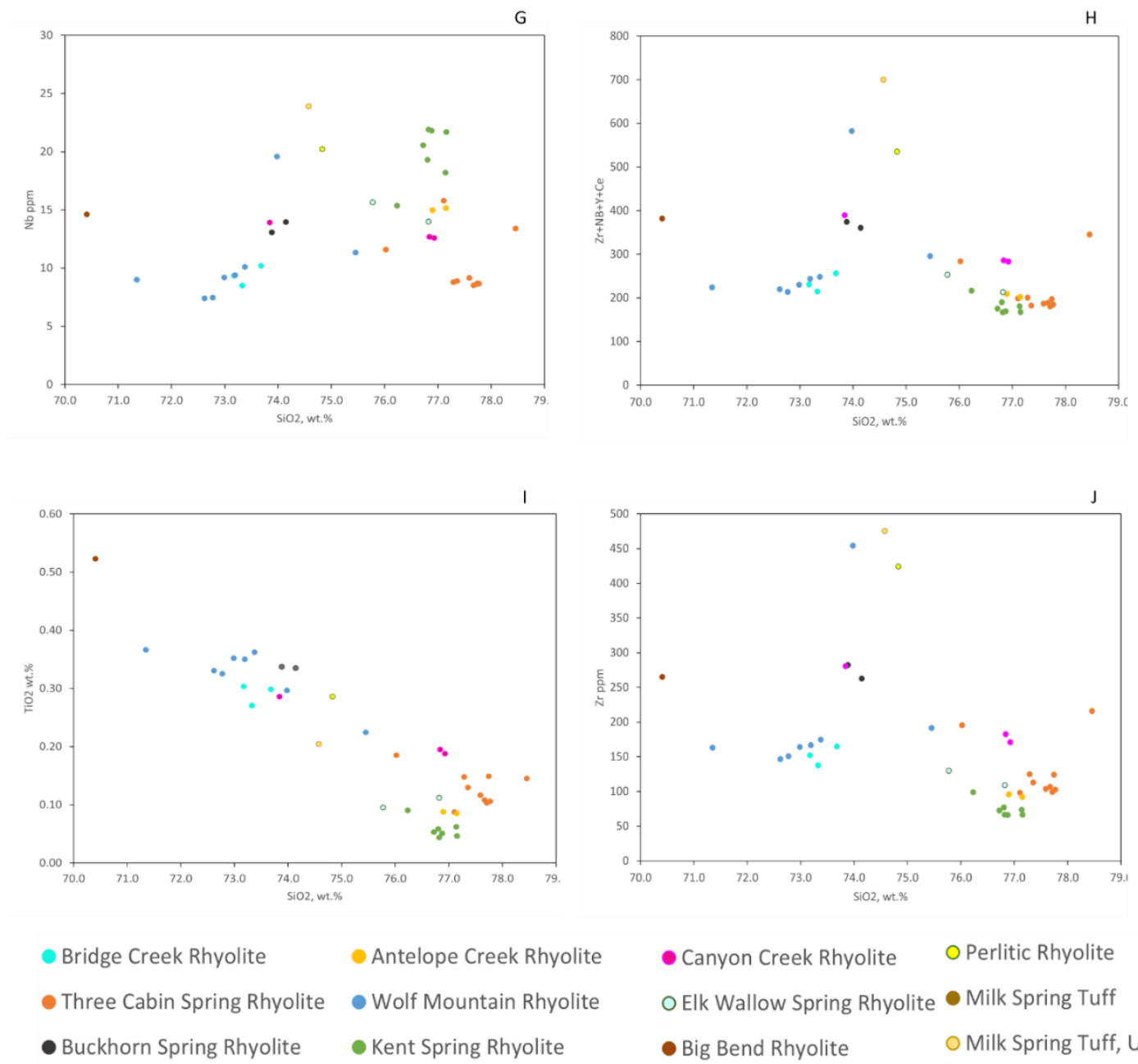
O Elk Wallow Spring Rhyolite Milk Spring Tuff

- Big Bend Rhyolite Milk Spring Tuff, Unit 1

Figure 50: This figure represents $\mathrm{G}$ through J plots (see Figure 49 for A through F) trace elements vs. $\mathrm{SiO}_{2} \mathrm{wt}_{\text {. }}$ $\%$ plots for the SV rhyolites. Plot G: $\mathrm{Nb}$ ppm vs. SiO2 wt. \%. Plot H: $(\mathrm{Zr}+\mathrm{Nb}+\mathrm{Y}+\mathrm{Ce})$ ppm vs. SiO2 wt.\%. Plot I: $\mathrm{TiO} 2$ wt. \% vs. SiO2 wt. \%. Lastly, Plot J: $\mathrm{Zr}$ ppm vs. SiO2 wt. \%.

\section{Trac - Rhyolite of Antelope Creek (Mid-Miocene)}

The rhyolite of Antelope Creek contains about $\sim 4 \%$ phenocrysts. Phenocrysts consist of quartz, plagioclase, biotite, and micorphenocrysts of Fe'Ti oxides. Samples are either devitrified and light grey in color or glassy to form obsidian. In the field, the plagioclase- 
phyric obsidian that makes for a black glassy rock with white speckles is the most characteristic feature to identify this unit (Figure 51).
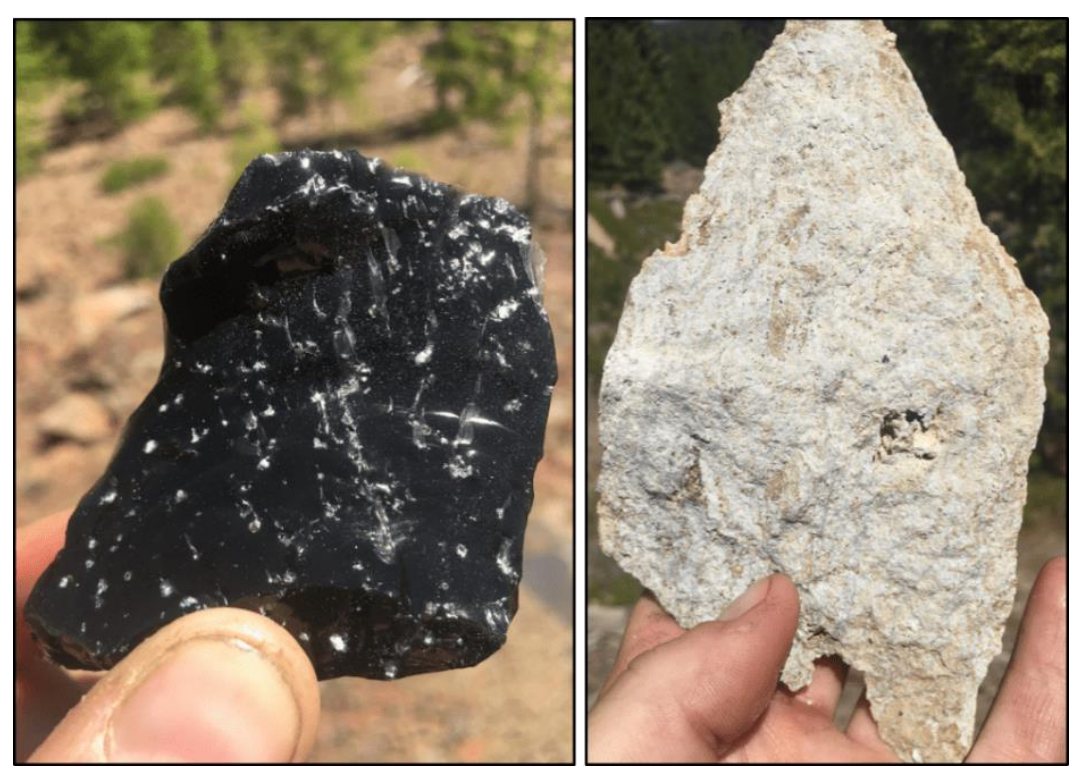

Figure 51: The image on the left is the obsidian member of Antelope Creek Rhyolite, and the right image is devitrified. Photos are from hand sample CD1879.

This unit crops out only sparsely in small areas along the southern border of the BC quad and the northern region of the JOJM quad. However, Trac crops out more extensively on the western side of LVW and MPT quadrangles. The devitrified member of Trac is not as abundant as its obsidian member. The area covered mapped outcrops of unit Trac is $\sim 12 \mathrm{~km}^{2}$ and has a thickness of about $30-70 \mathrm{~m}$. Based on two analyses of a Trac, an obsidian sample from the Jump-off Joe Mountain and the Logan Valley West quadrangles. The Antelope Creek rhyolite has a typical silica percentage of about $77 \%$ and a slightly higher $\mathrm{Nb}$ value of 14.9 (Figure 50). 


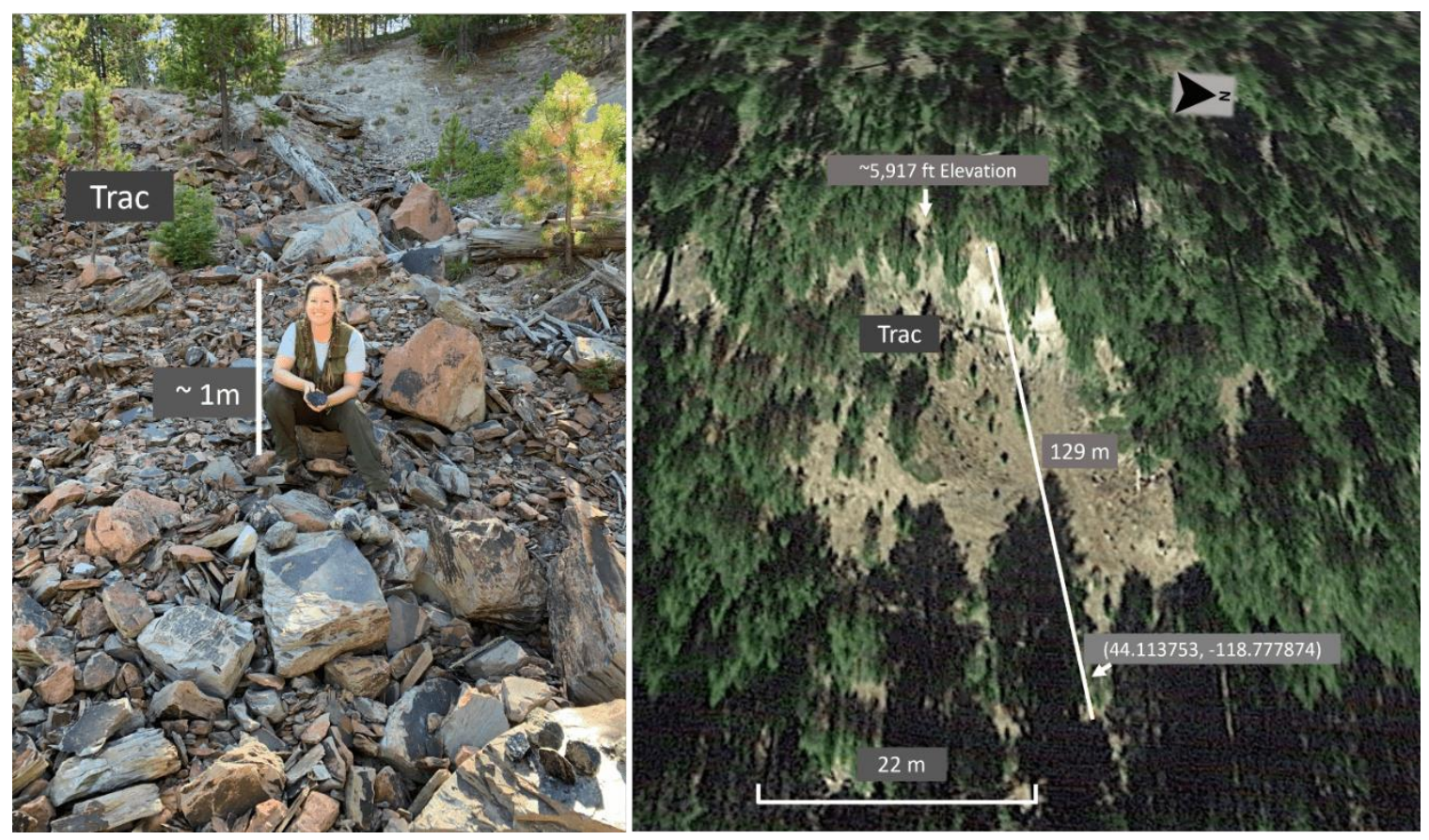

Figure 52: Photos are from the exact outcrop location in the JOJM quadrangle where sample CD1879 was collected. The image on the left highlights the obsidian member of Trac, and the top of the hill is where its devitrified member is found. The image on the right measures from the top of the outcrop to the road, recording a thickness of $129 \mathrm{~m}$. Just east of this outcrop, an NW trending fault dips to the NE towards this outcrop. The fault could be accounting for some displacement thus thickness, where a typical Trac outcrop thickness ranges from $30-70 \mathrm{~m}$.

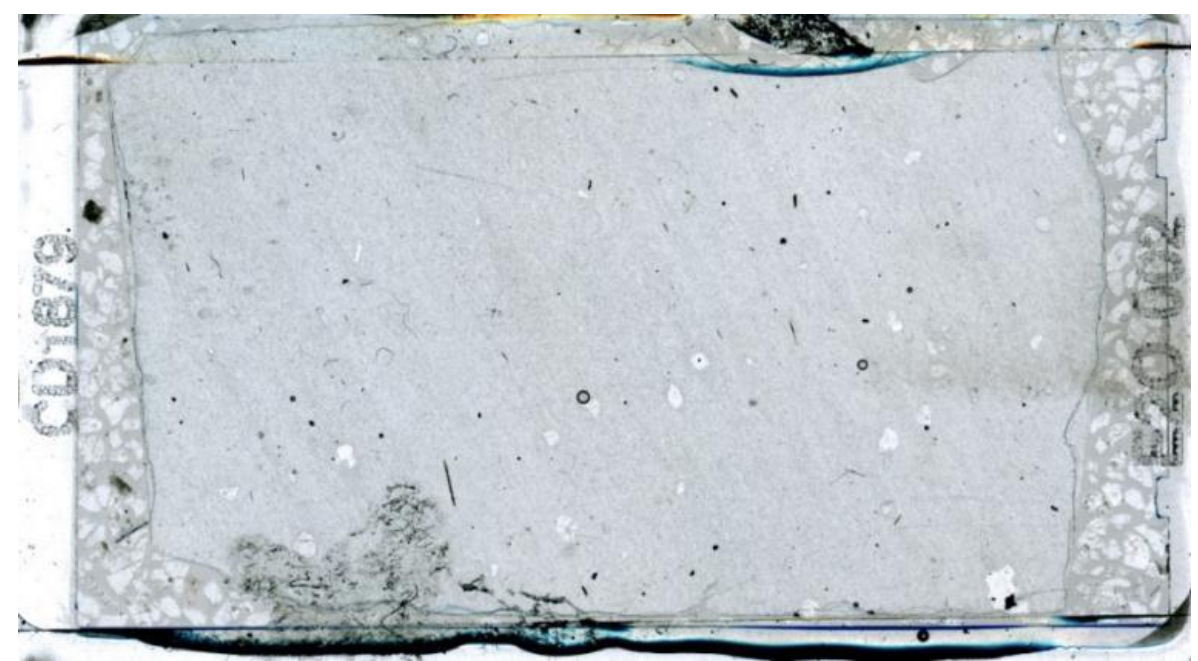

Figure 53: Obsidian of Antelope Creek rhyolite as full thin section image, showing about 4\% phenocrysts, clear quartz and plagioclase, and dark shaded acicular biotite. 


\section{Trbs - Rhyolite of Buckhorn Spring (Mid-Miocene)}

The rhyolite of Buckhorn Spring is stratigraphically one of the youngest rhyolite units of the Strawberry Volcanics and overlies the bedded fallout and ignimbrite unit of Ttms. Trbs is exclusively confined to the furthest north-eastern reaches of the $\mathrm{BC}$ and LVW map near its highest elevation peaks, and it reached into the quads to the north that was not mapped. Trbs is light in color. Generally, a pale pink to purple with elongated white streaks along the rocks parallel-spaced fractures and portrays faint flow bands. Hand samples are devitrified with little to no clearly visible phenocrysts. The mapped outcrop area for Trbs is $\sim 1 \mathrm{~km}^{2}$ with a unit thickness of about $20-120 \mathrm{~m}$.

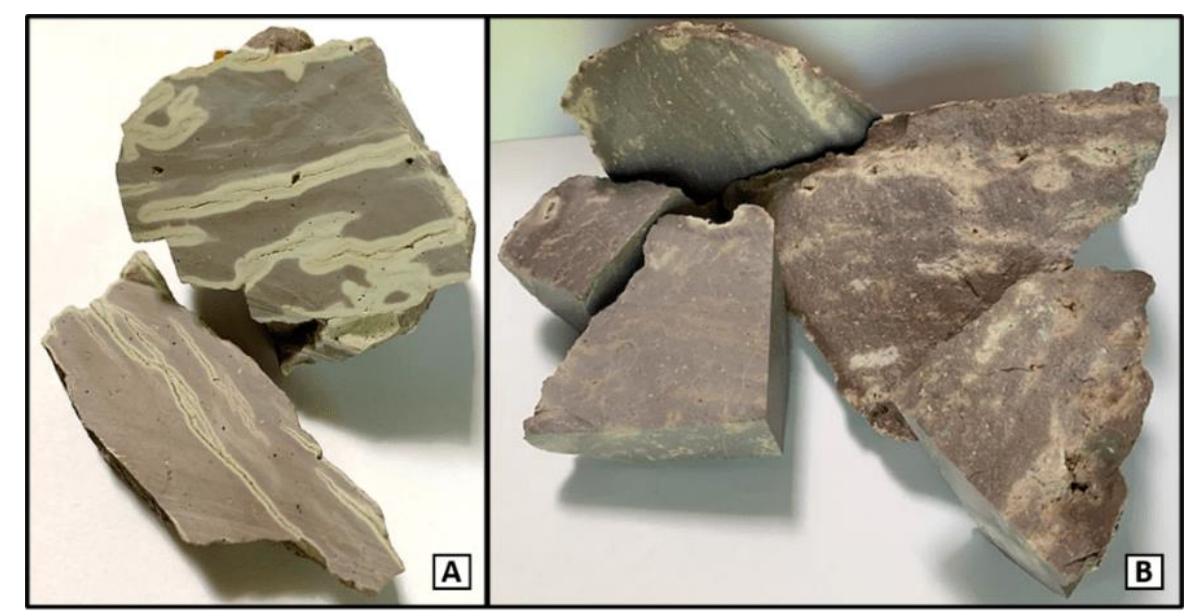

Figure 54: Hand samples of rhyolite of Buckhorn Spring unit (A) BC19C30 sample and (B) BC19C37 sample.

The sample BC19C30 was used for petrographic analysis. In thin section, the groundmass is devitrified with aligned groundmass crystals indicating flow banding. Phenocryst content is low, less than $2 \%$ consisting of plagioclase. The average silica percentage of devitrified Trbs is $74 \%$ wt. $\mathrm{SiO}_{2}$ and has a $\mathrm{LOI} \%$ of 1.08 . 


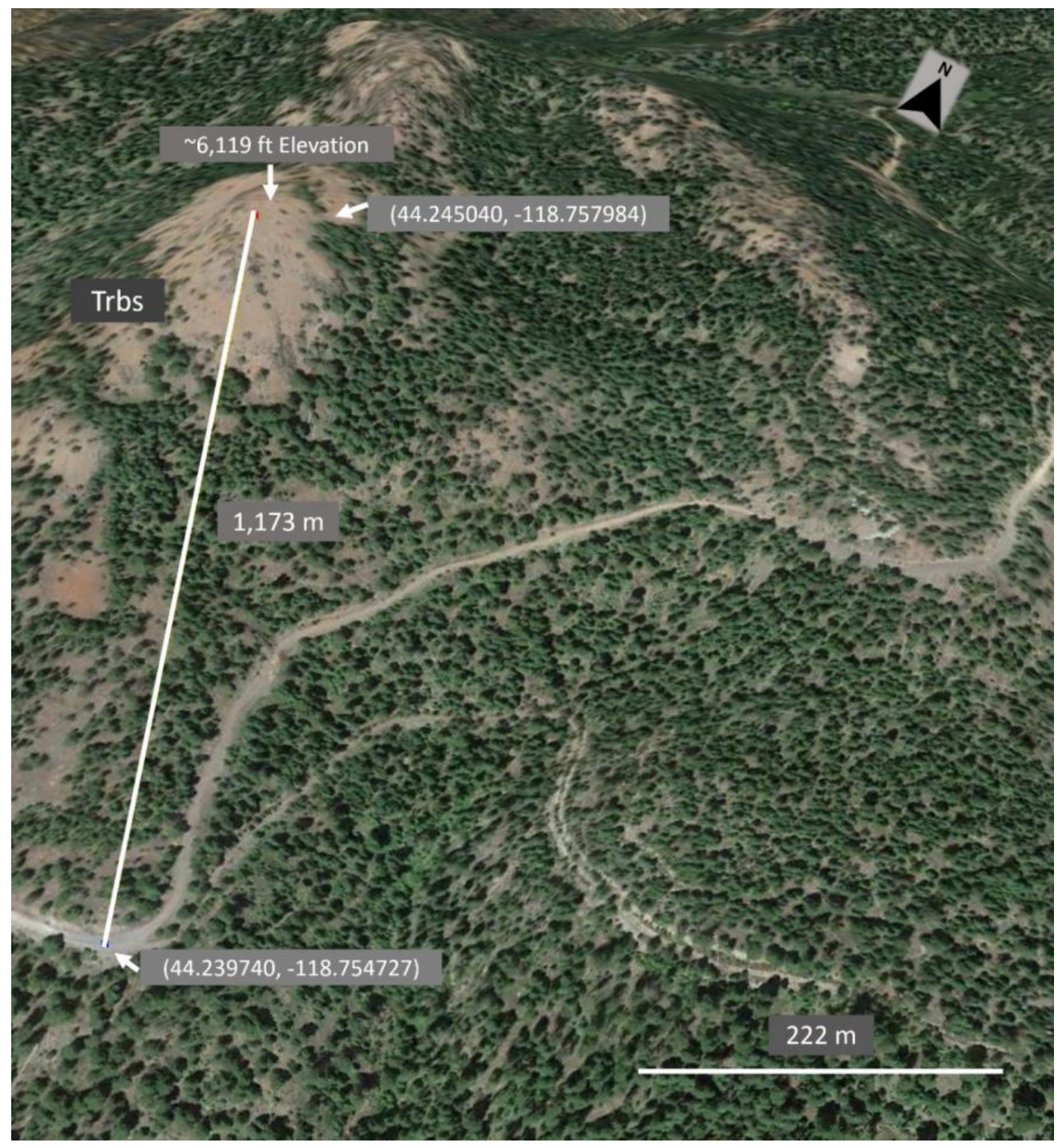

Figure 55: This image representing Trbs highlights this unit's highest peak and most exposed region in the BC quadrangle. About $1 \mathrm{~km}$ west of this peak, a fault runs north-south for about $7 \mathrm{~km}$ in length, dipping east. This extensional faulting and the youth of the Trbs unit itself would account for its significant cliffside exposures. Trbs typically has a thickness of about $20-120 \mathrm{~m}$. 


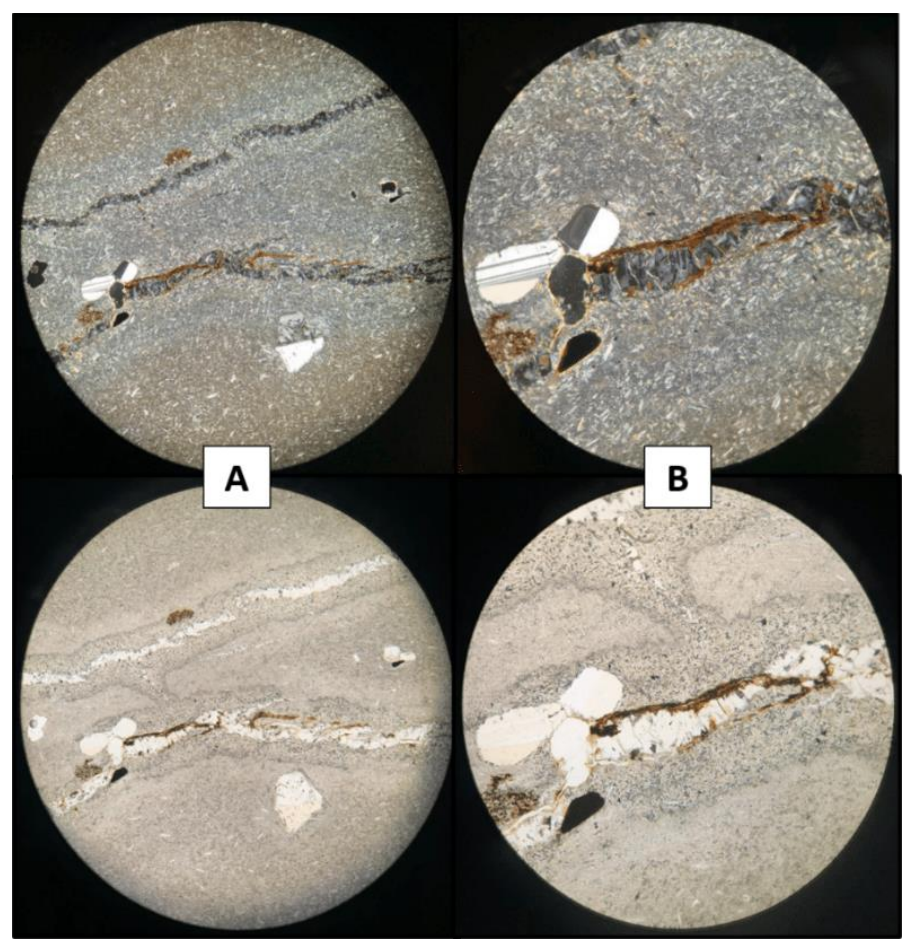

Figure 56: Images of the Rhyolite of Buckhorn Spring in thin section from sample BC19C30. The row of images on top is represented in XPL, and the bottom row is in PPL. Image (A) is in 100X optical zoom, with (B) in 40X optical zoom.

\section{Trcc - Rhyolite of Canyon Creek (Mid-Miocene)}

The rhyolite of Canyon Creek crops out strictly in the northern half of the $\mathrm{BC}$ and LVW quadrangles and is possibly the best-exposed rhyolite unit in the region. Outcrops of this unit strike east-west, a thin layer of Trcc is found mainly as float that appears at an elevation of roughly $5000 \mathrm{ft}$ in the far north-eastern region of $\mathrm{BC}$ quad. Trcc lies stratigraphically below the andesite and basalt to basaltic andesite of the Strawberry Volcanics (Tasv, Tbsv). Lavas of Tasv and Tbsv appear to fill a paleotopography that Trcc created, likely enhanced by erosional processes. Samples of rhyolite of Canyon Creek are light gray-purple color and devitrified, often exhibiting flow banding with some yellow secondary staining. 
Rhyolite breccia can be found at the base or top of these outcrops. This is also where the glassy facies of Trcc appears either as dense obsidian or more porous, perlitic rhyolite. Devitrified and glassy samples are aphyric to extremely phenocryst poor. The thickness of Trcc can be up to $\sim 100 \mathrm{~m}$, forming large cliff faces that likely extend below the canyon bottom. The mapped outcrops for Trcc amounts to $\sim 6 \mathrm{~km}^{2}$.

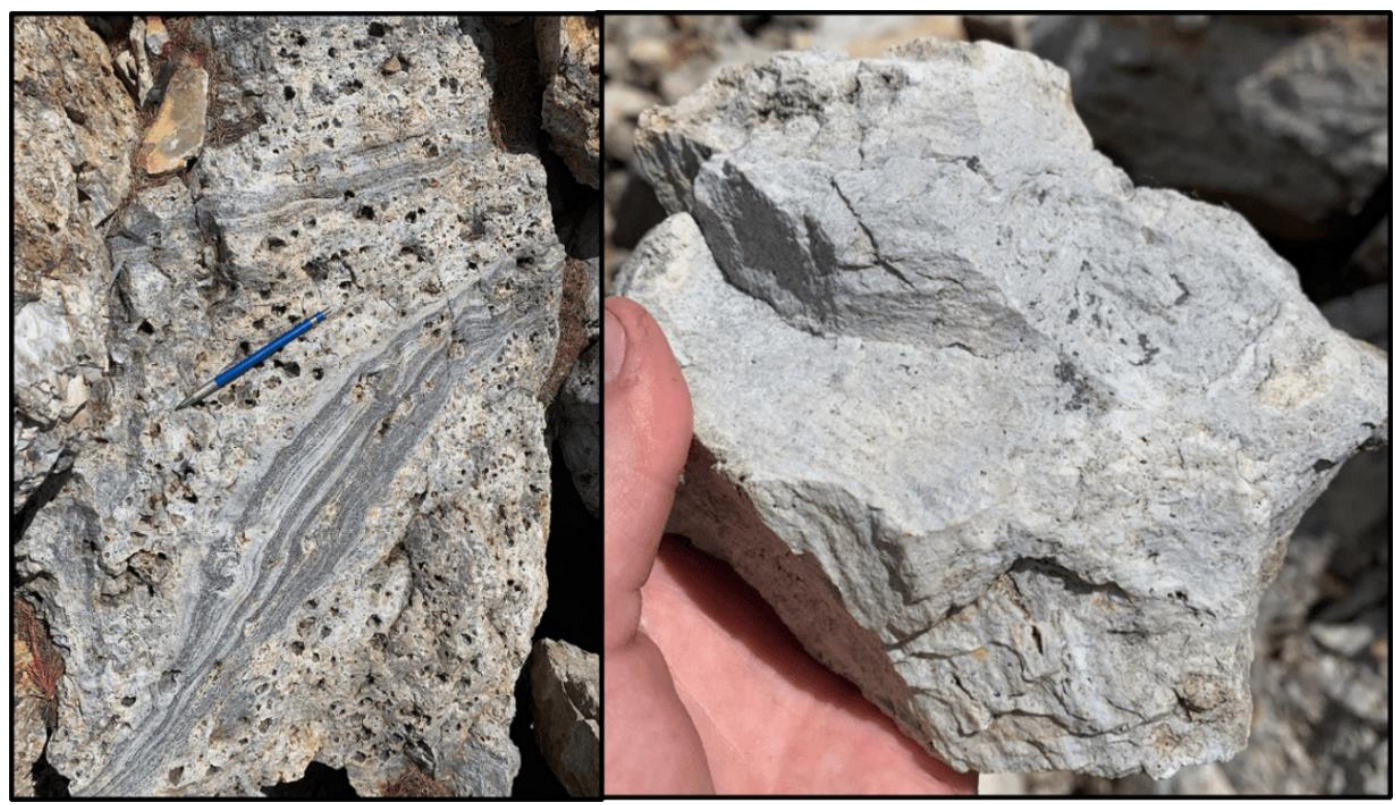

Figure 57: Outcrop of rhyolite of Canyon Creek located in the map's furthest north-eastern corner (sample CD1943).

One devitrified thin section of Trcc (sample BC19A11) consists of very fine groundmass crystals. Some of these crystals are aligned, indicating flow banding. The rhyolite contains scarce mono- and polymineralic glomerocrysts. Geochemical analysis of three samples indicates an average of $75.9 \mathrm{SiO}_{2}$ wt. $\%$. 


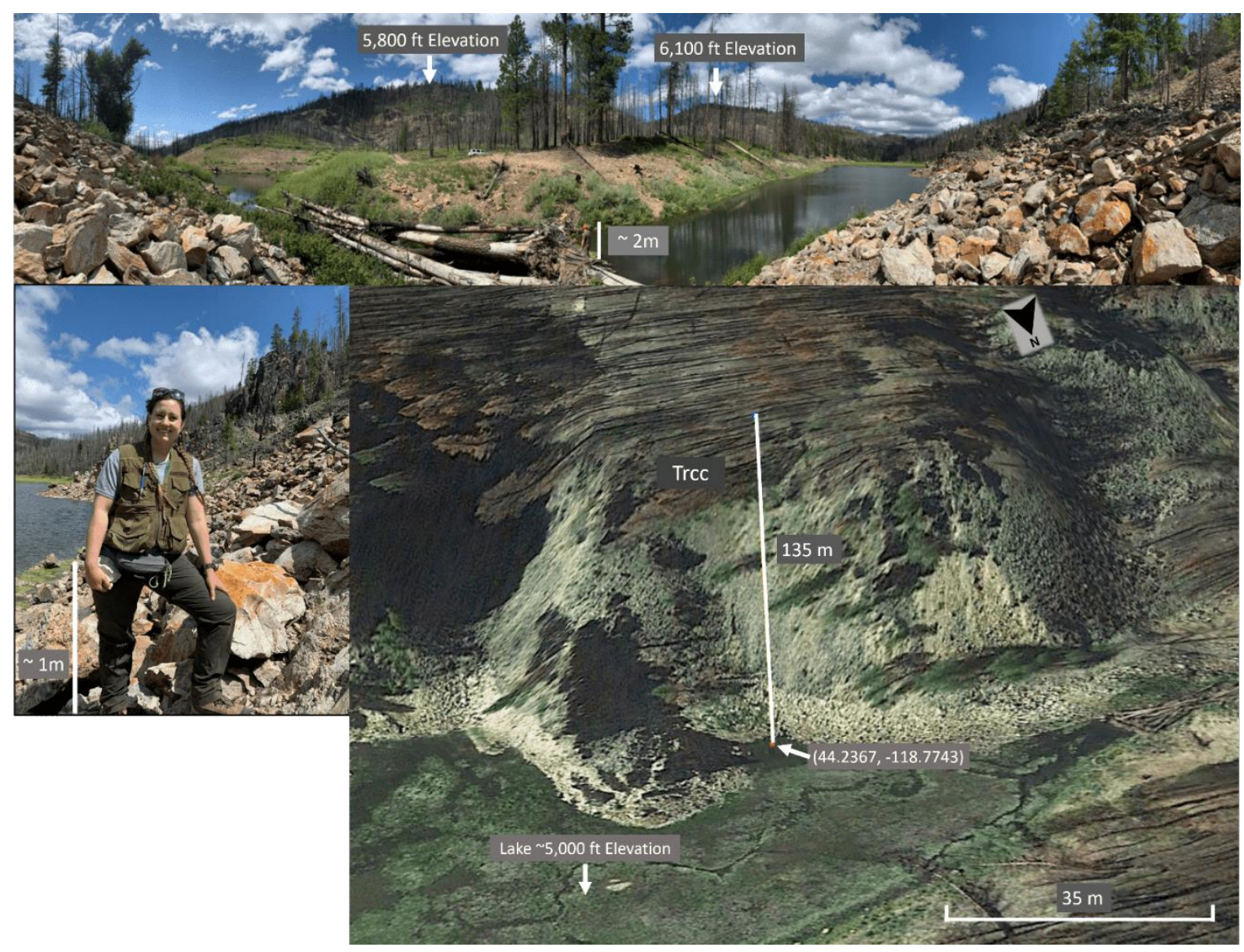

Figure 58: These images represent the rhyolite of Canyon Creek. This unit is very well exposed as it lies on a fault that runs north-south for about $7 \mathrm{~km}$ in length and dips to the east. The east block, which incorporated the unit Trcc and its outcrop pictured, has also formed a lake in its offset. The top image shows the lake meeting Trcc in outcrop. The bottom right map was generated in Google Earth to measure the unit's exposure. The unit thickness measurement occurred from the south side of the lake to the adjoining peak. Its thickness measures $135 \mathrm{~m}$, which is an accurate high range thickness value for Trcc. 


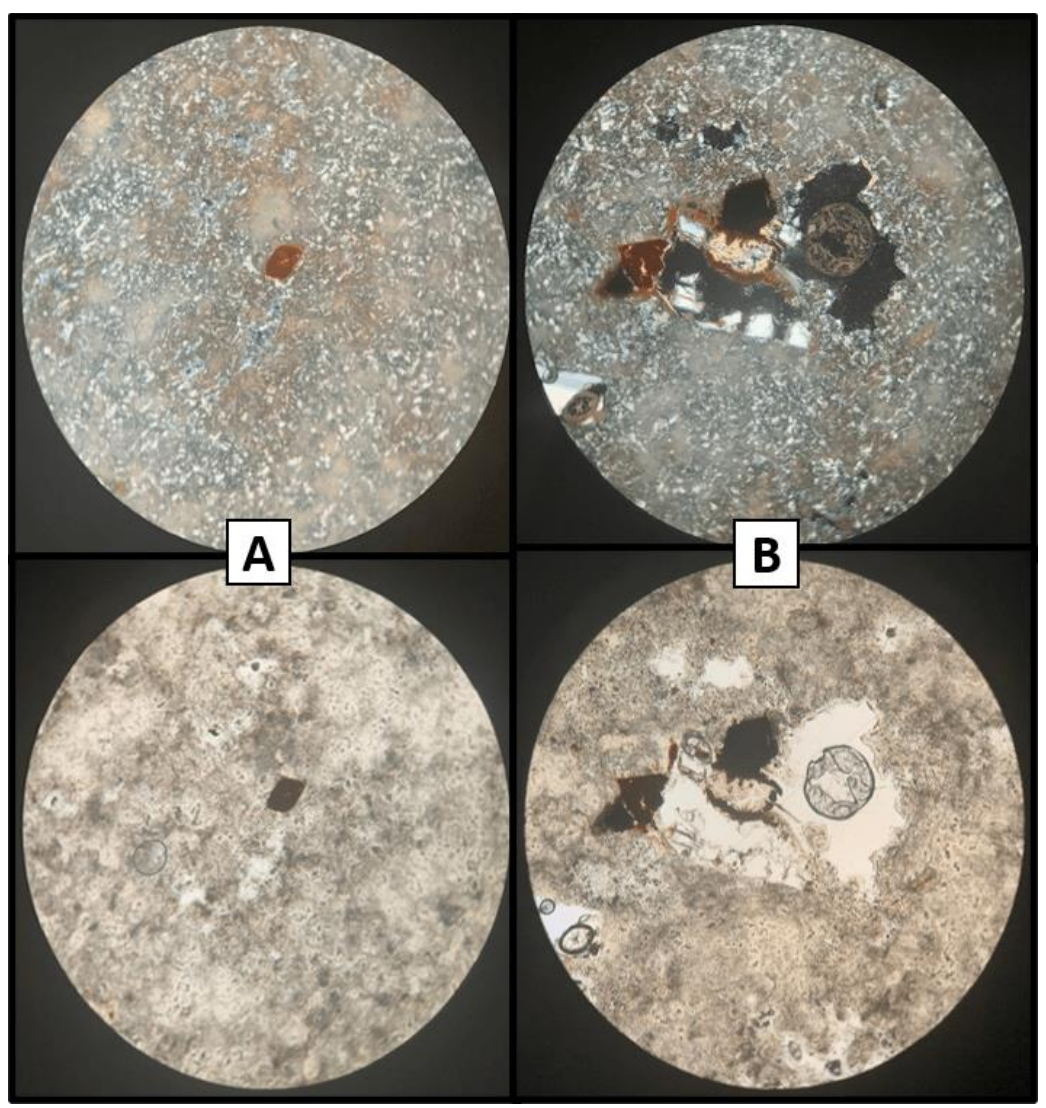

Figure 59: Thin section images of Canyon Creek rhyolite from float sample BC19A11 with images in XPL on top and PPL at the bottom (A) in 100X optical zoom and (B) in 40X optical zoom.

\section{Trks - Rhyolite of Kent Spring (14.4 Ma)}

Rhyolite of Kent Spring is a crystal poor rhyolite that crops out largely in the central region of the entire mapping region. This unit is only seen in this portion of the mapping area and is distinguishable by the presence of amphibole and its low phenocryst content. The outcrops mapped in the field for Trks amount to $\sim 22 \mathrm{~km}^{2}$ with a unit thickness range of 40$200 \mathrm{~m}$. Glassy samples are typically porous with a dull luster and have a light grey groundmass with $1 \%$ amphibole and $\sim 1 \%$ plagioclase phenocrysts. The Ba ppm concentration of samples of Trks trends towards the lower concentrations with slightly increased $\mathrm{SiO}_{2}$ (Plot B of Figure 
49), suggesting that alkali feldspar just started to crystallize. Samples of this unit typically yield a silica content of $\sim 77$ wt. $\% \mathrm{SiO}_{2}$. Single crystal age dating by the ${ }^{40} \mathrm{Ar} /{ }^{39} \mathrm{Ar}$ method on plagioclase from sample CD1975 yielded an age of $14.37 \pm 0.02 \mathrm{Ma}$ (see Appendix).

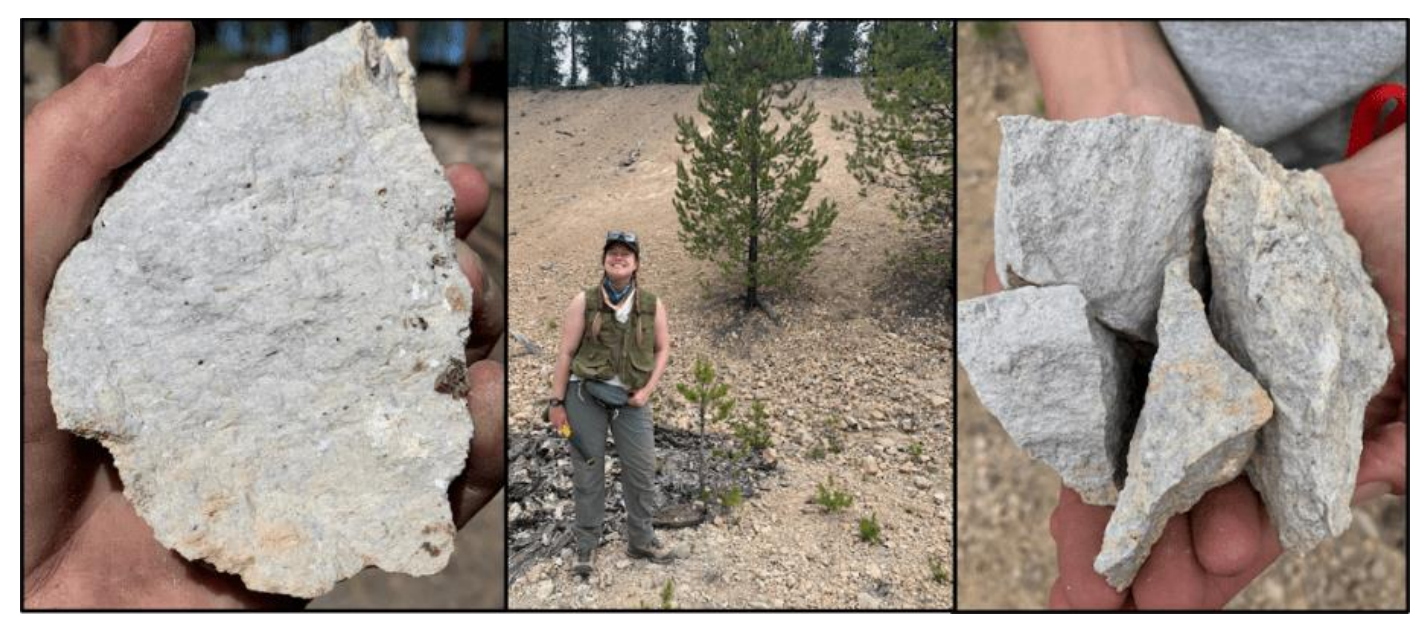

Figure 60: Kent Spring rhyolite (CD1932). Overall, the unit is crystal poor and distinguishable by the presence of amphibole. 


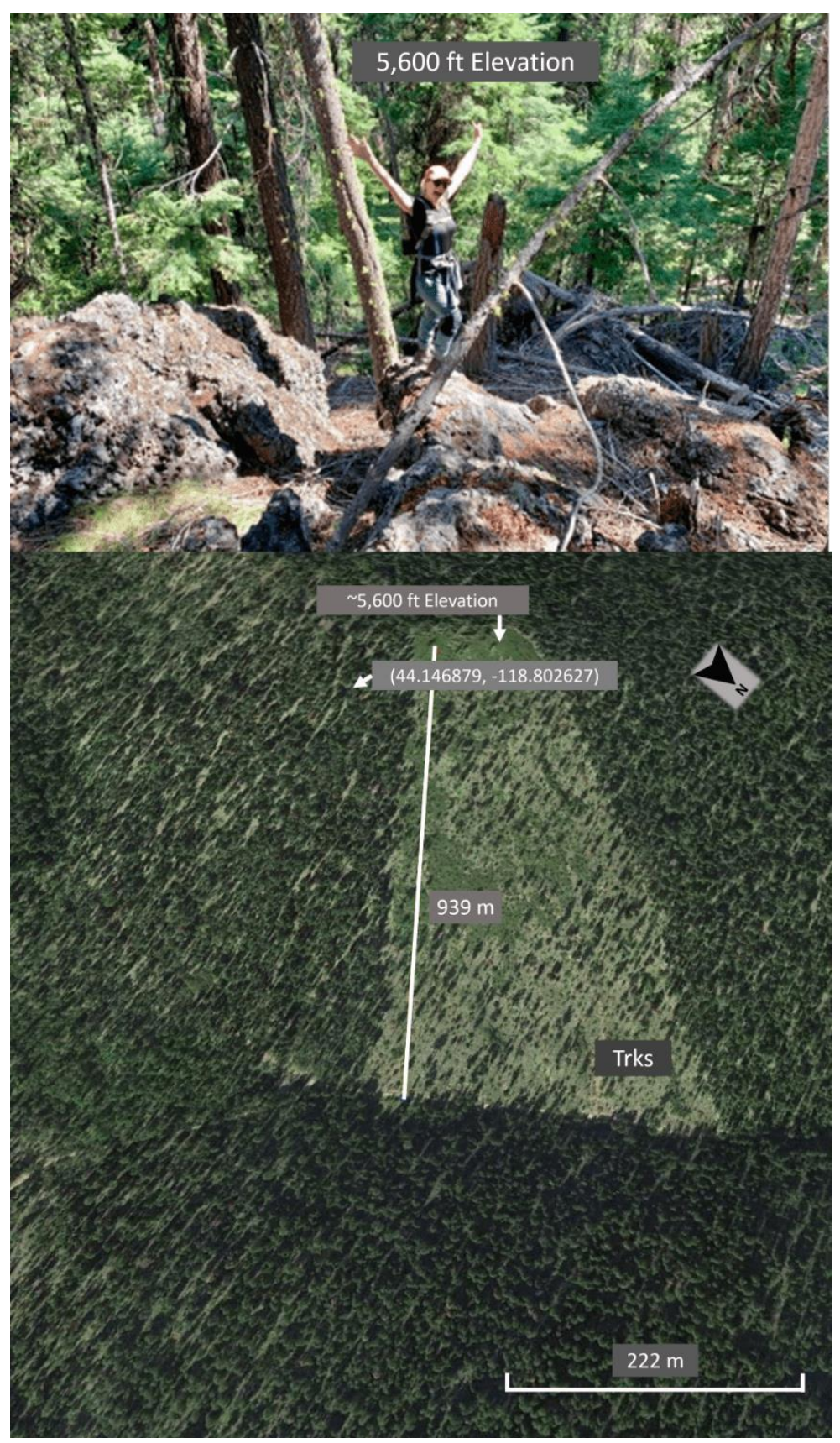

Figure 61: These images represent the rhyolite of Kent Spring and its amount of exposure due to faulting in the region. Both images are from the same outcrop, located in the far SE of the BC quadrangle. Four north-south trending faults intersect this unit in an east-dipping extensional domino effect, generating considerable exposure. With Trks remaining relatively local to this area, its typical maximum unit thickness is about $200 \mathrm{~m}$. The map image was produced on Google Earth along with geologic mapping knowledge of the region. 


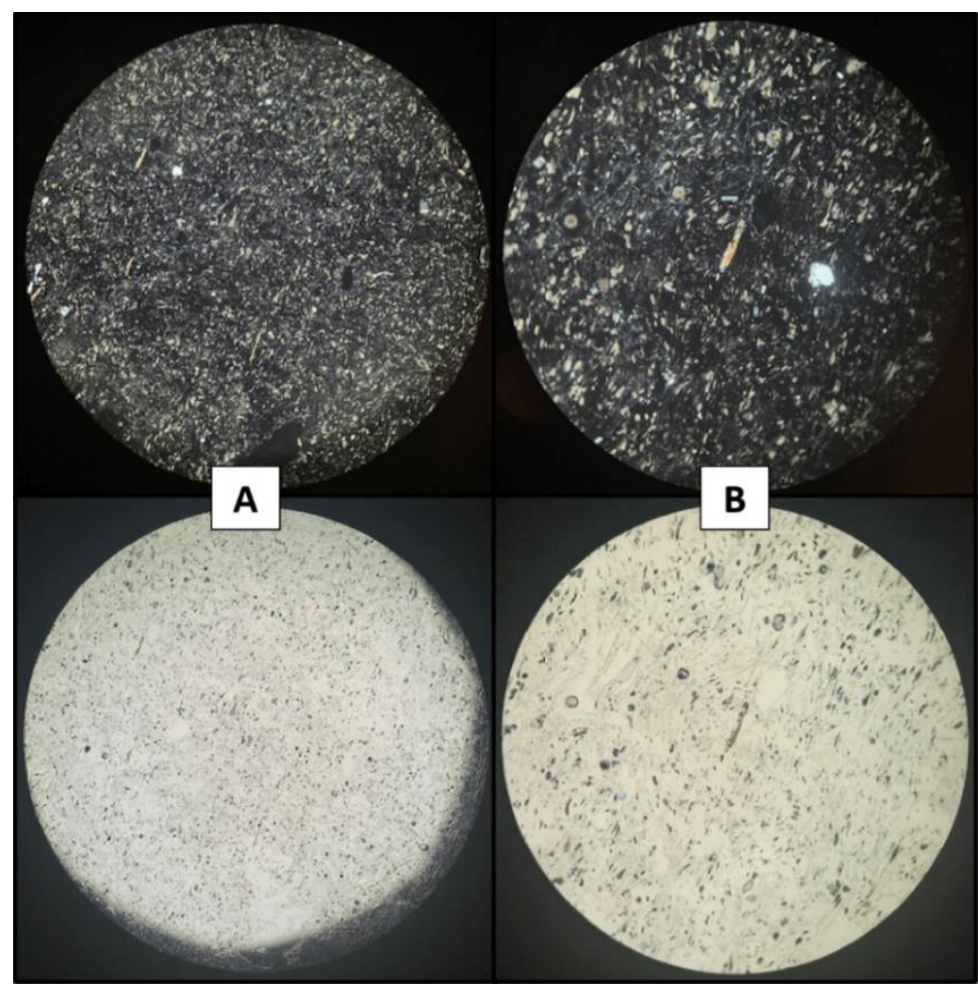

Figure 62: Thin section images of Kent Spring rhyolite sample CD1932. The top row of images is in XPL, and the bottom row is in PPL. Image (A) is in 40X optical zoom, whereas (B) is in 100X optical zoom, shown crystal poor nature with about $1 \%$ amphibole crystals.

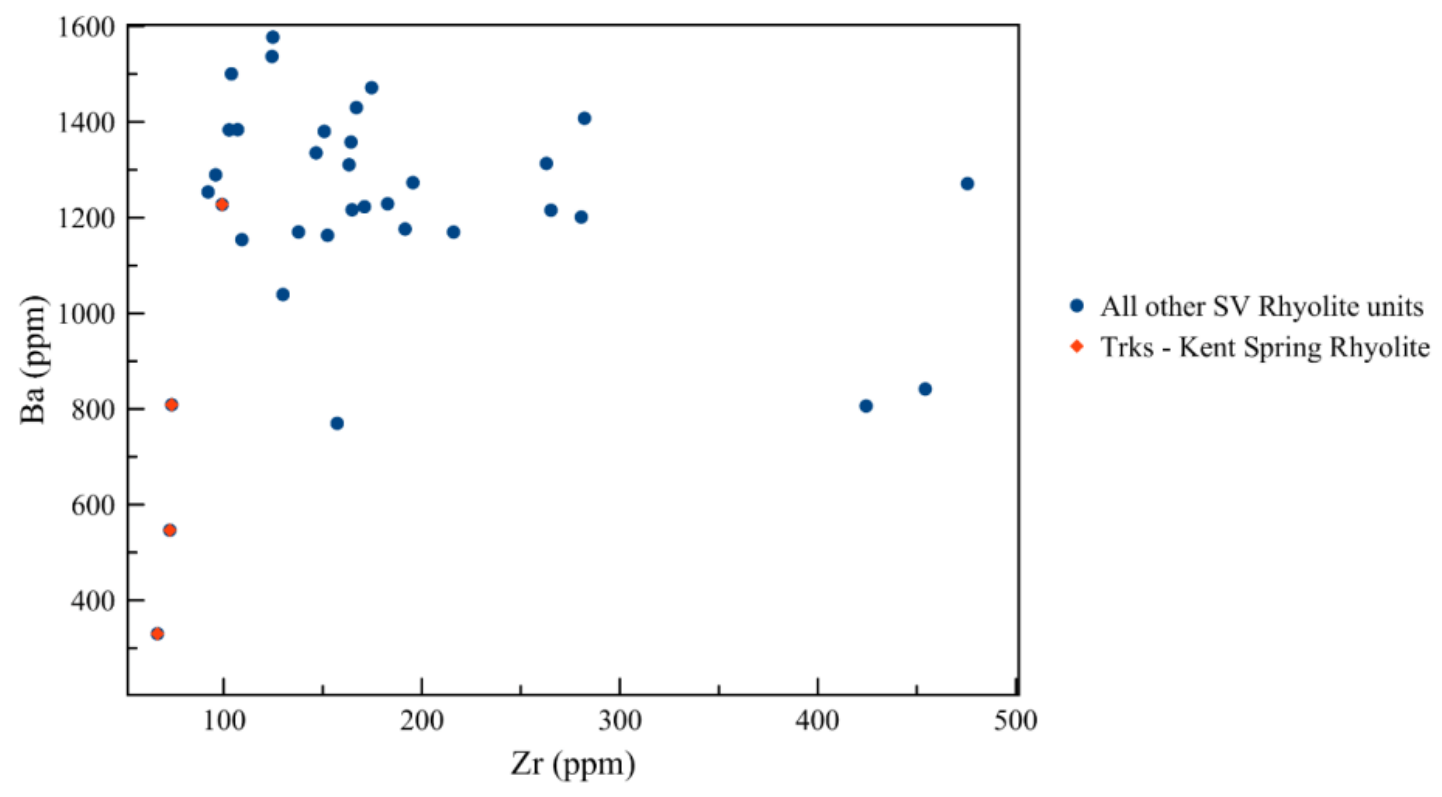

Figure 63: Ba vs. Zr variation diagram for the Strawberry Rhyolites, highlighting samples of unit Trks (red). The unit Trks has a distinctly lower $\mathrm{Zr}$ ppm than the other SR units. 


\section{Trews - Rhyolite of Elk Wallow Spring (Mid-Miocene)}

The rhyolite of Elk Wallow Spring is found in the southwestern region of LVW and primarily in the northwestern half of MPT quads. Trews is found in outcrop to be vitric to often devitrified with flow banding. The mapped outcrop area for Trews is $\sim 17 \mathrm{~km}^{2}$ with a unit thickness up to $200 \mathrm{~m}$.

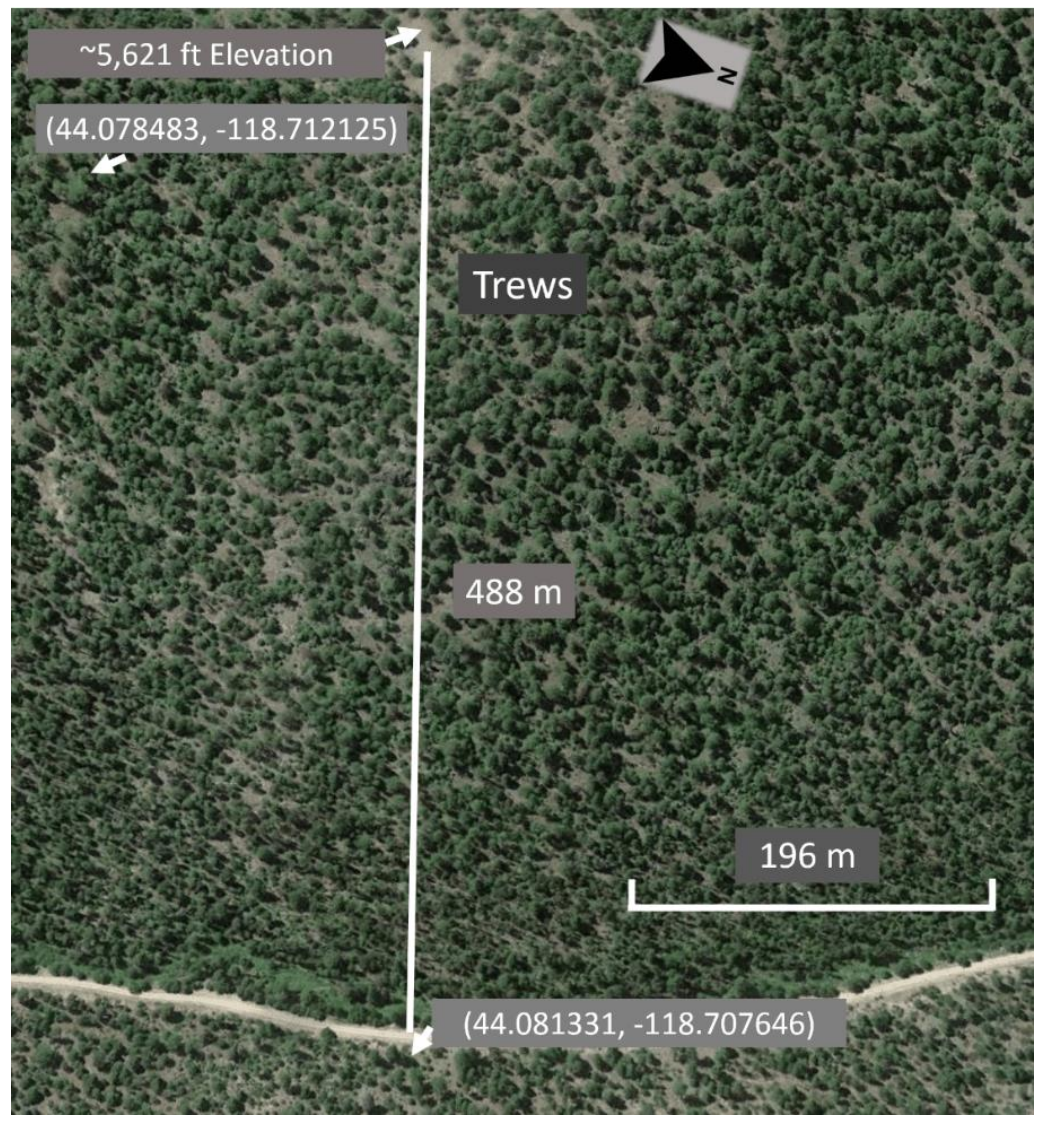

Figure 64: The image is of the Rhyolite of Elk Wallow Spring, where the highest elevation is atop Glass Mountain in MPT and is the sample location for RS20MPT03. The map image was generated using Google Earth and used knowledge of where this unit crops out in the study area. Trews crops out in this location and covers this entire, overall wedged between Trtcs and Trac. Using this model, Trews unit thickness measures about $488 \mathrm{~m}$. The measurement of the unit may have a deviation as many faults that trend north-south just to the east of this location, crossing into neighboring quads of JOJM and BC. The faults are dipping to the east, generating domino extensional features. A typical unit thickness will range from 40-200m, making sense for this unit's location in the study area. 
This rhyolite contains about 2-4\% phenocrysts. Phenocrysts include plagioclase, quartz, amphibole, and lesser biotite. Amphibole can be quite large, 1-4mm euhedral to subeuhedral grains (Figure 66). The biotite phenocrysts occasionally contain zircon inclusions. Outcrops of Trews are typically massive to slaty and fissile, with a tendency to be white to dark gray in color. A sample of this unit typically yields a silica content of around 76 wt. \% $\mathrm{SiO}_{2}$. This unit differs from that of Trbc by its strontium and zirconium concentrations (Figure 67). With Trews averaging about $59 \mathrm{ppm}$ of Sr and $118 \mathrm{ppm}$ of $\mathrm{Zr}$, where Trbc is more than three times that amount for Sr at about $196 \mathrm{ppm}$ and has a value of $152 \mathrm{ppm}$ of Zr.

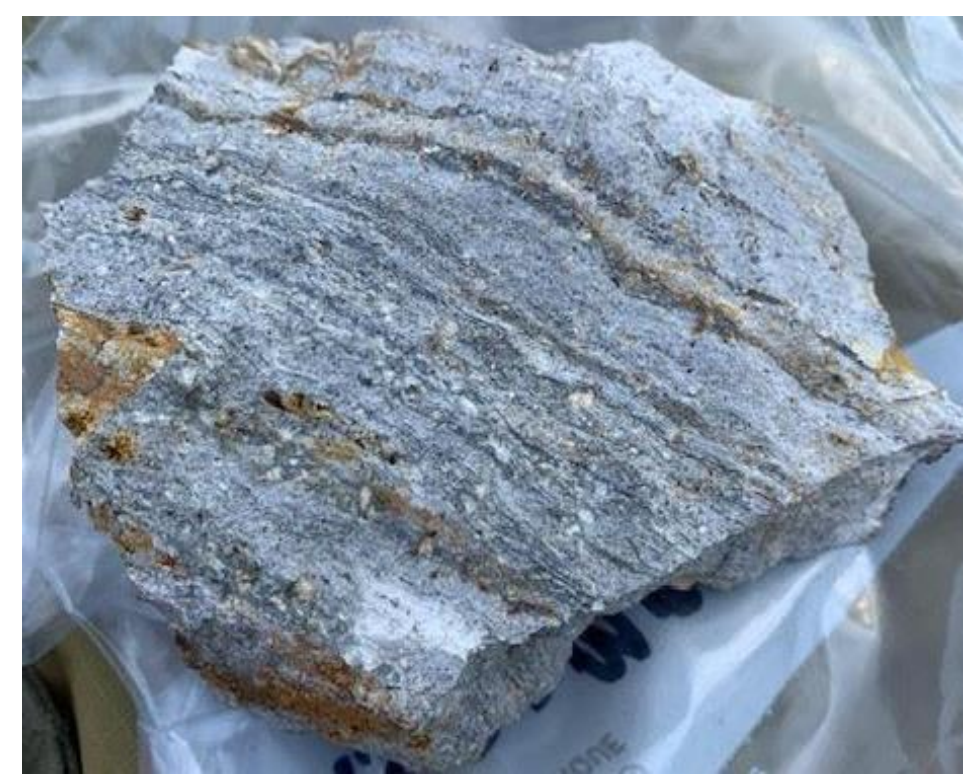

Figure 65: Hand sample of the rhyolite of Elk Wallow Spring. This sample is from the top of Glass Mountain in the Magpie Table quadrangle (RS20MPT03). 


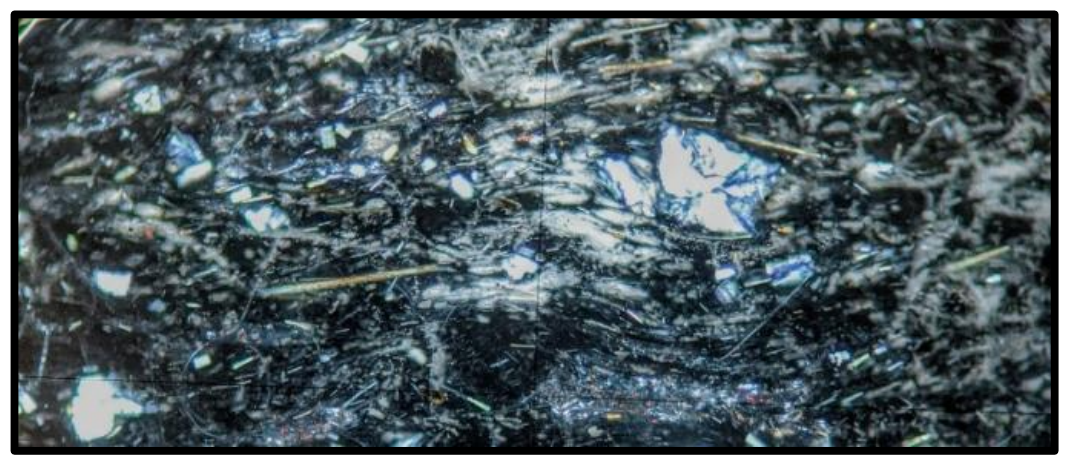

Figure 66: Petrographic thin section of Trews from the MPT quadrangle. Flow banded, with prominent acicular phenocrysts of hornblende and plagioclase phenocrysts in a glassy, flow banded groundmass.

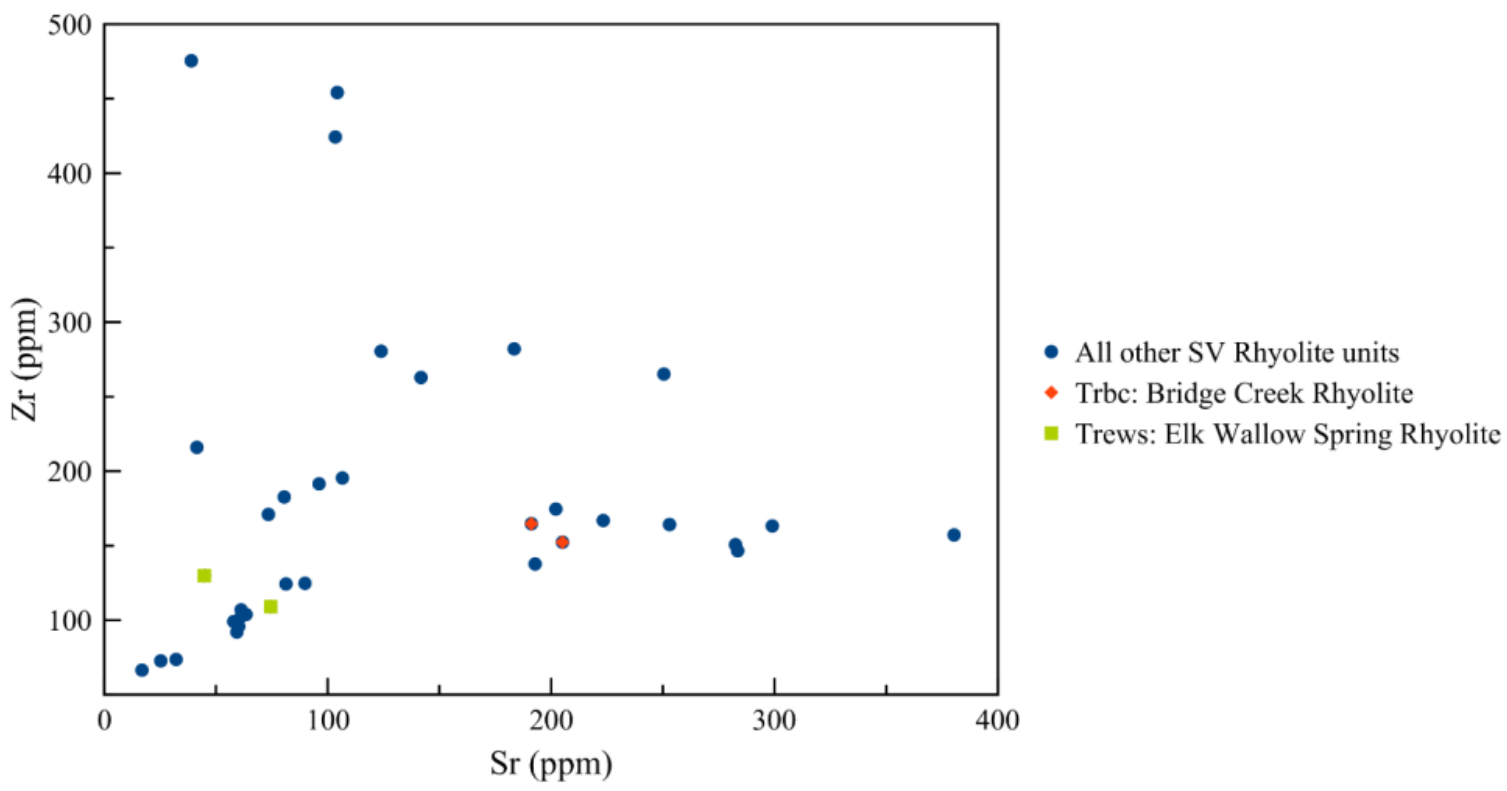

Figure 67: Zr vs. Sr variation diagram for the Strawberry Rhyolites, highlighting unit Trews (green) and Trbc (red) samples. The unit Trews and Trbc are lithologically similar but can be differentiated by their trace elements. Specifically, Zr and Sr, where the unit Trews has an overall lower Zr and Sr trace element concentration than the unit Trbc. 


\section{Trbb - Rhyolite of Big Bend (Mid-Miocene)}

The rhyolite of Big Bend is only found in a small region in the southwestern region of the LVW quadrangle near the Big Bend drainage area, where it clearly overlies Tasv andesitic lavas and thus appears to be one of the younger rhyolites. In outcrop, this rhyolite was most often found to be highly weathered. Outcrops varied between massive and platy and often appeared to have spherulites covering the surface. This unit is typically light gray in color with occasional elongated vesicles indicative of flow. The field mapped outcrops for Trbb amount to $\sim 0.9 \mathrm{~km}^{2}$ and has a thickness range of $20-40 \mathrm{~m}$. Distinct from Trtcs and Trbs, this unit contains about $4 \%$ of large $(2-3 \mathrm{~mm})$ plagioclase phenocrysts and pseudomorphs after pyroxene within a fine-grained groundmass (Figure 68 and Figure 69). Geochemical analysis of this unit, sample LVW-N2-2, has a silica content of 70.4 wt. $\% \mathrm{SiO}_{2}$.

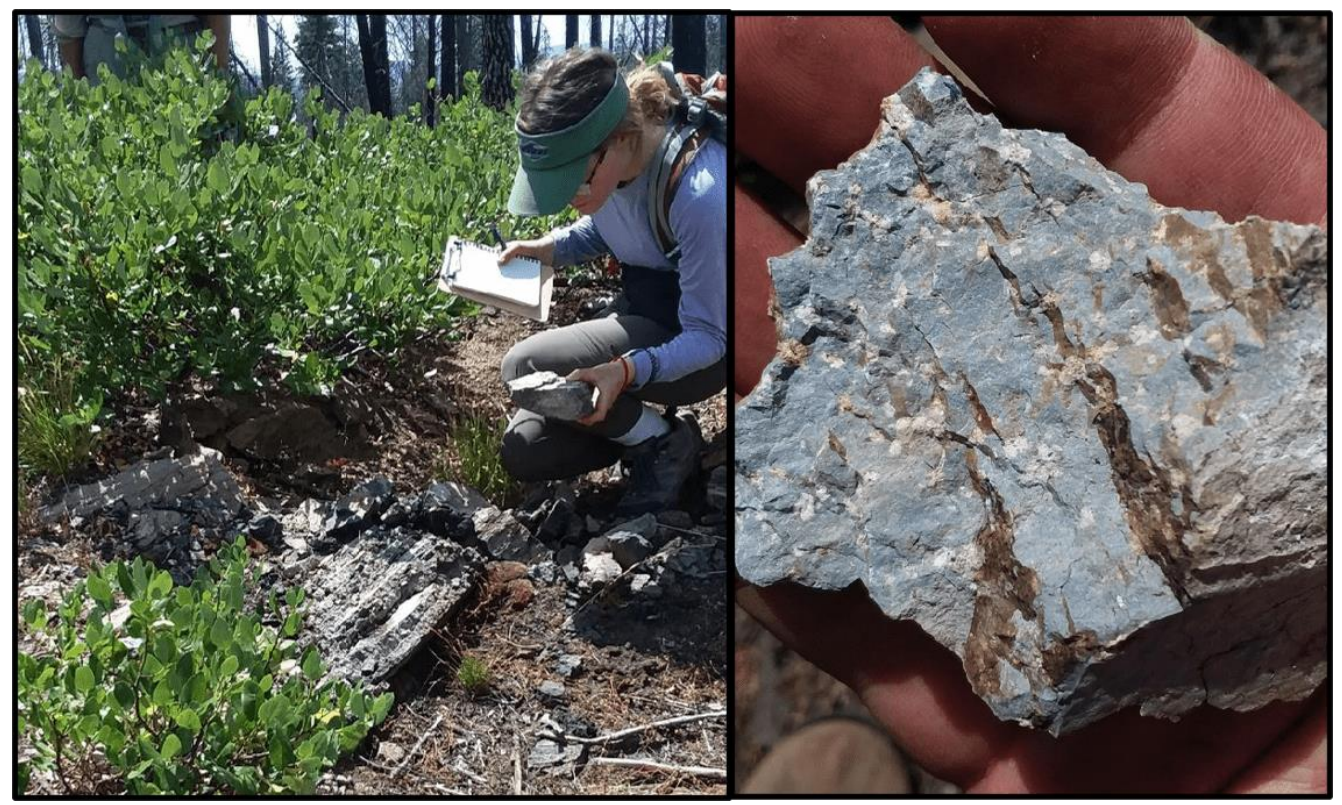

Figure 68: The image on the left is a typical outcrop of Trbb. The image on the right is a classic representation of this units' phenocrysts percentage. 


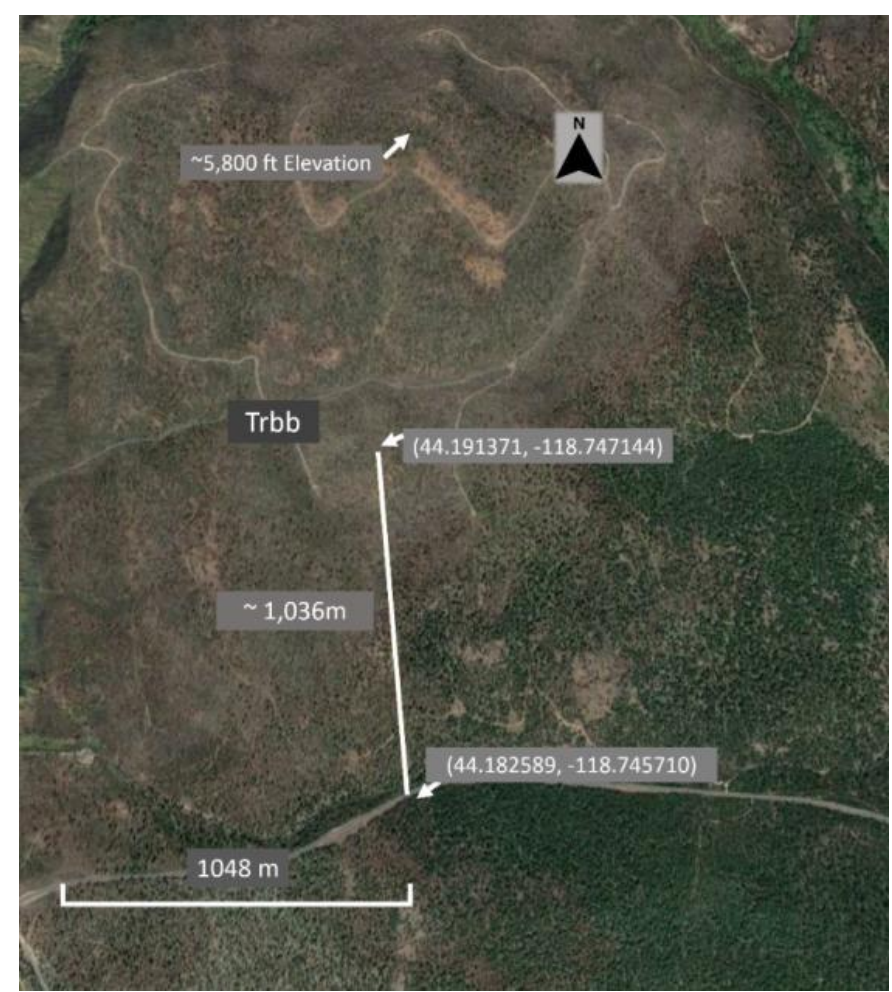

Figure 69: Image is of the Rhyolite of Big Bend; the map image was generated using Google Earth and by using knowledge of where this unit crops out in the study area. Trbb crops out in this location and overall only in a small portion throughout the entire map, $\sim 1 \mathrm{~km}^{2}$. Using this model, Trbb unit thickness measures about $1,039 \mathrm{~m}$ at maximum. This area is in close proximity to Bear Creek. Large alluvium-filled meadow and creek. Directly to the west, in the quadrangle BC, there are a couple of outlier faults that trend from east to south, where all other faults in the region tend to be normal faults. I suspect that this potentially active faulting is the cause of this rather large unit thickness. Especially regarding Trbb is one of the younger, if not youngest SR unit.

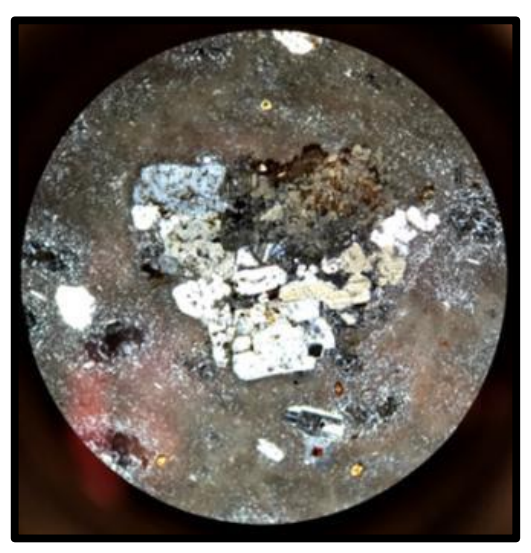

Figure 70: Thin section image of unit Trbb in XPL from sample LVW-N-19. The thin section image features a very fine-grained matrix encompassing glomerocrysts. 


\subsubsection{PHENOCRYST RICH UNITS}

I. Trbc - Rhyolite of Bridge Creek (14.7- 14.3 Ma)

The rhyolite unit of Bridge Creek was observed primarily along the western margins of the JOJM quadrangle. Outcrops are typically large and blocky (Figure 71). They range in color from pinkish to medium gray, depending on the amount of devitrification. When Trbc is found in outcrop as glassy, samples are light and porous and do not form an obsidian member. The actual mapped outcrop area from the field for Trbc is $\sim 20 \mathrm{~km}^{2}$ with a thickness up to $100 \mathrm{~m}$.

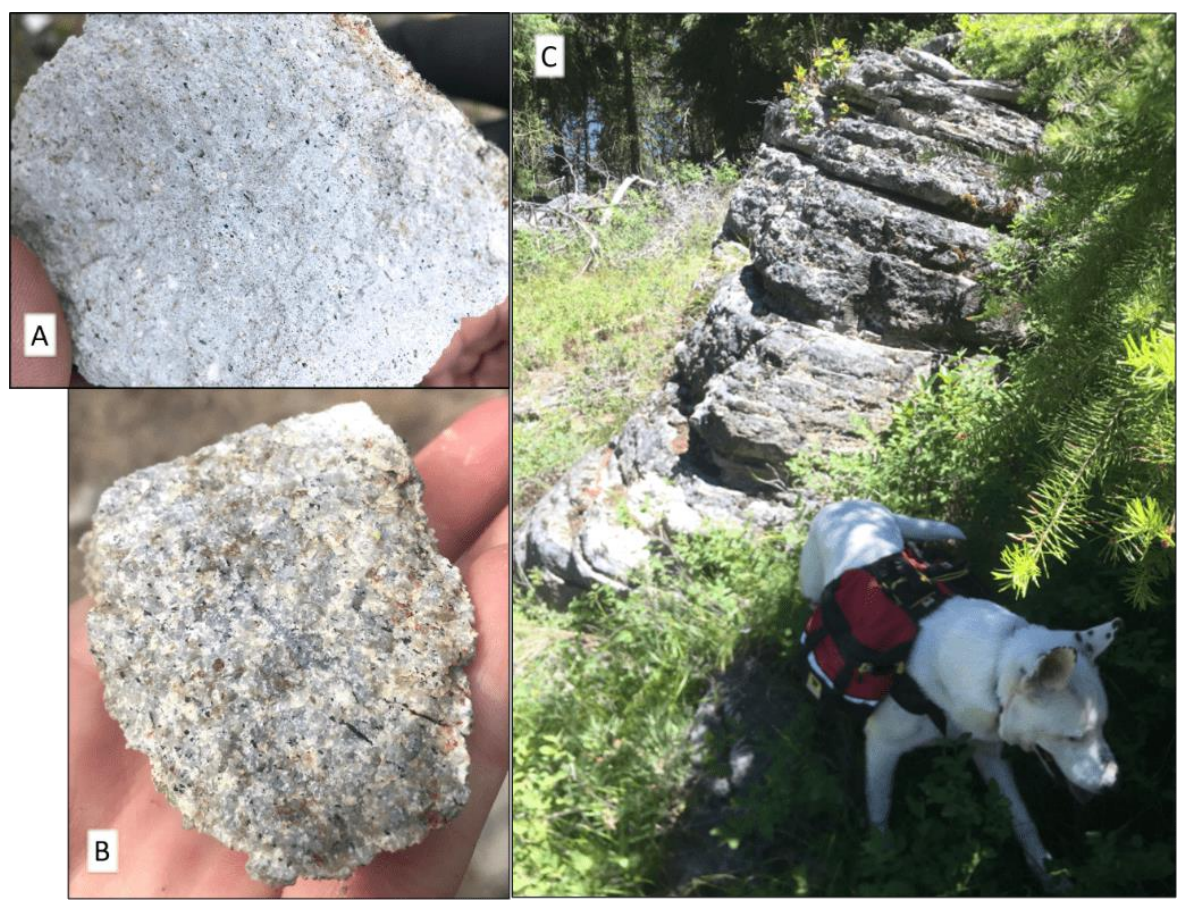

Figure 70: (A) Hand sample of Trbc, devitrified with amphibole and biotite, clearly visible. (B) Vitric hand sample of Trbc, outcrop just south of Che Spring in JOJM. (C) A smaller outcrop of the Bridge Creek Rhyolite is consistently found amongst a sizeable blocky and more extensive outcrop. 
Samples of Trbc contain about $10-20 \%$ phenocrysts. The most abundant phase is complexly zoned plagioclase $8-15 \%$ plagioclase, about subequal amounts of biotite and amphibole make up about 3-5\% and lesser orthopyroxene and FeTi oxides. When devitrified, there are only pseudomorphs after pyroxene. In addition, there are rare phenocryst-size quartz crystals ( $<5$ per thin section). Trbc has an average silica content of 73.4 wt. \% $\mathrm{SiO}_{2}$. Figure 67 shows the trace elements of $\mathrm{Zr}$ ppm plotted vs. Sr ppm. This trace element plot differentiates Trbc from unit Trews with biotite and amphibole phenocrysts as found in Trbc (Figure 71).

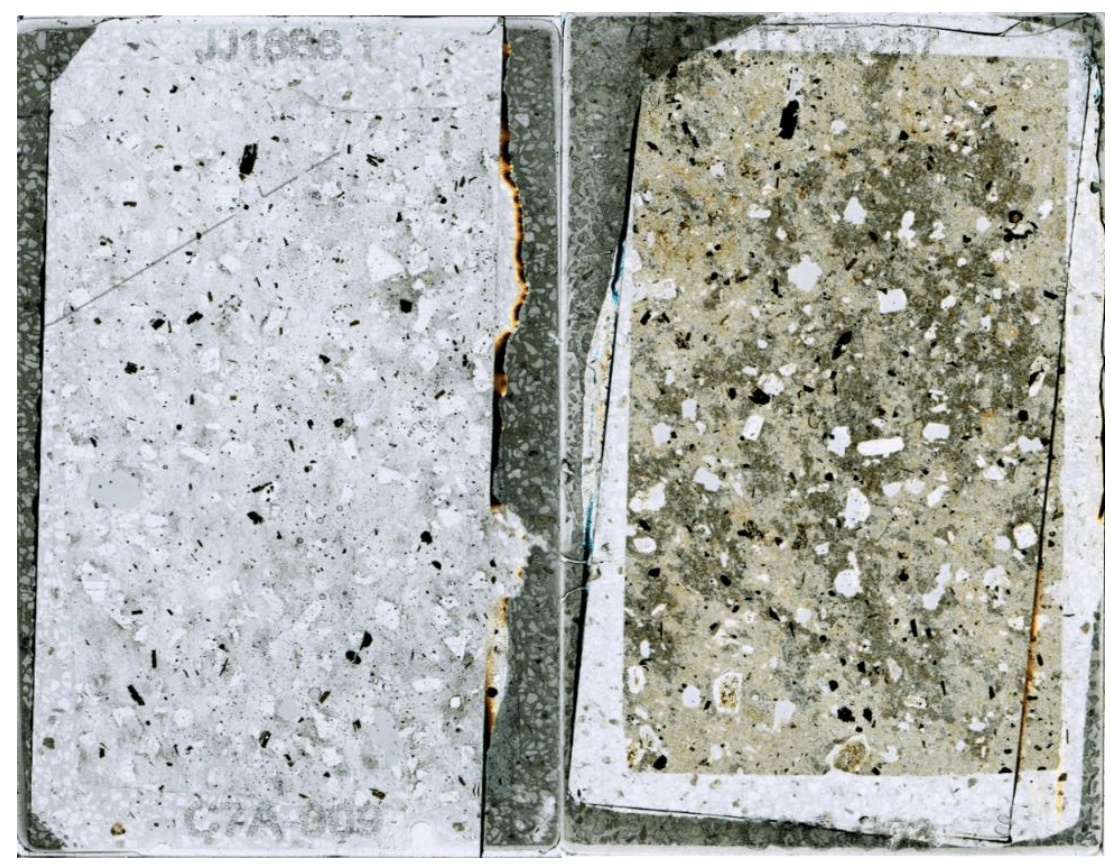

Figure 72: Thin section of the Rhyolite of Bridge Creek. Full slide images, the left is in PPL, and the right image is in XPL, from sample JJ18A257. The thin section highlights the abundance of clearly visible biotite and amphibole crystals, making up about $3 \%$, with about $8 \%$ plagioclase. 

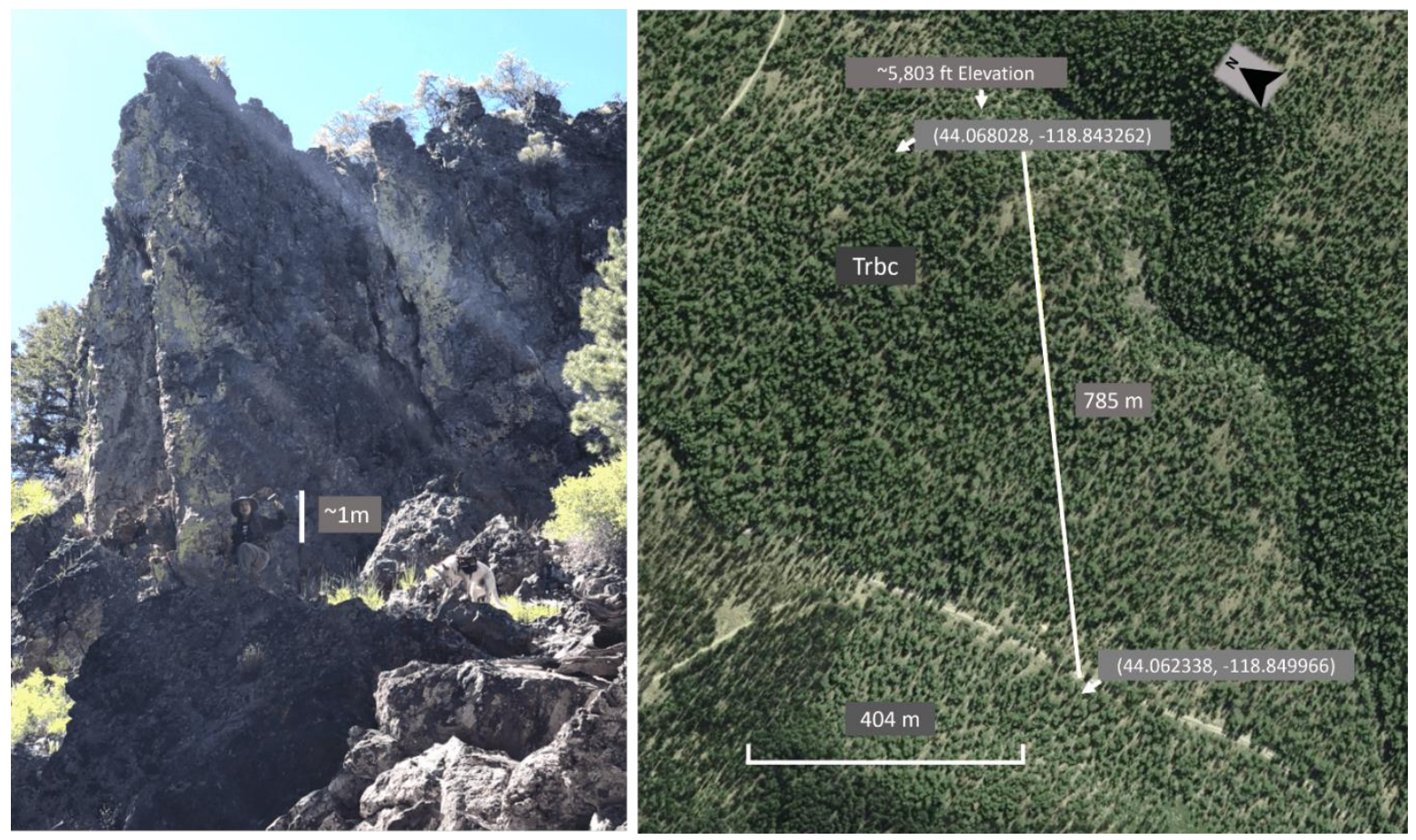

Figure 73: Photos are of the Rhyolite of Bridge Creek (formerly known as the unit Tsvr in the 2019 JOJM map). The left image is from the JOJM quadrangle, NW of Bond Spring. The image on the right was generated using Google Earth and subsequent knowledge of this unit within the study area. The majority of Trbc crops out in this location covering the entire hill, continuously reaching the NE and SW, covering a stretch of $\sim 7 \mathrm{~km}$. Using this model and a prominent location of a continuous outcrop of Trbc, its unit thickness measures about $785 \mathrm{~m}$. The sizeable unit thickness estimate is likely due to the extensional faulting throughout the region, exposing a substantial face of Trbc. Thus, a typical unit thickness will range from 40-100m.

\section{Trwm - Rhyolite of Wolf Mountain (16.1-15 Ma)}

Rhyolite of Wolf Mountain is found extensively in the eastern half of the JOJM and the western margin of MPT quadrangles. Trwm is also found in a relatively small area within the $\mathrm{BC}$ map, and its plagioclase phenocrysts tend to remain relatively small in size but abundant in quantity. This rhyolite is distinct in how crystal-rich it is, ranging from $20-30 \%$ plagioclase. Flow banding is also prevalent, with bands consisting of pink to grey colors (Figure 74). Hand samples of Wolf Mountain rhyolite are dark to light grey when glassy or devitrified or 
are exclusively pinkish in color when devitrified. The outcrops mapped in the field for Trwm amount to $\sim 59 \mathrm{~km}^{2}$, being the largest rhyolite in the project area and has a unit thickness up to $200 \mathrm{~m}$.

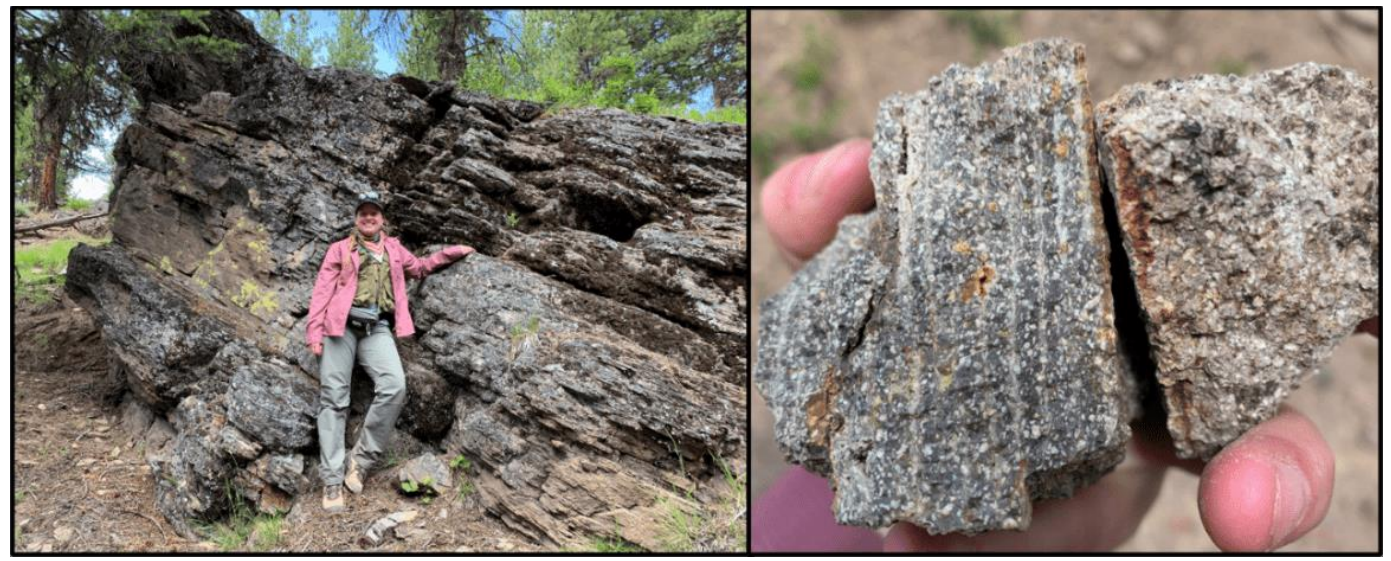

Figure 74: Wolf Mountain rhyolite in outcrop and as hand sample (CD1921).
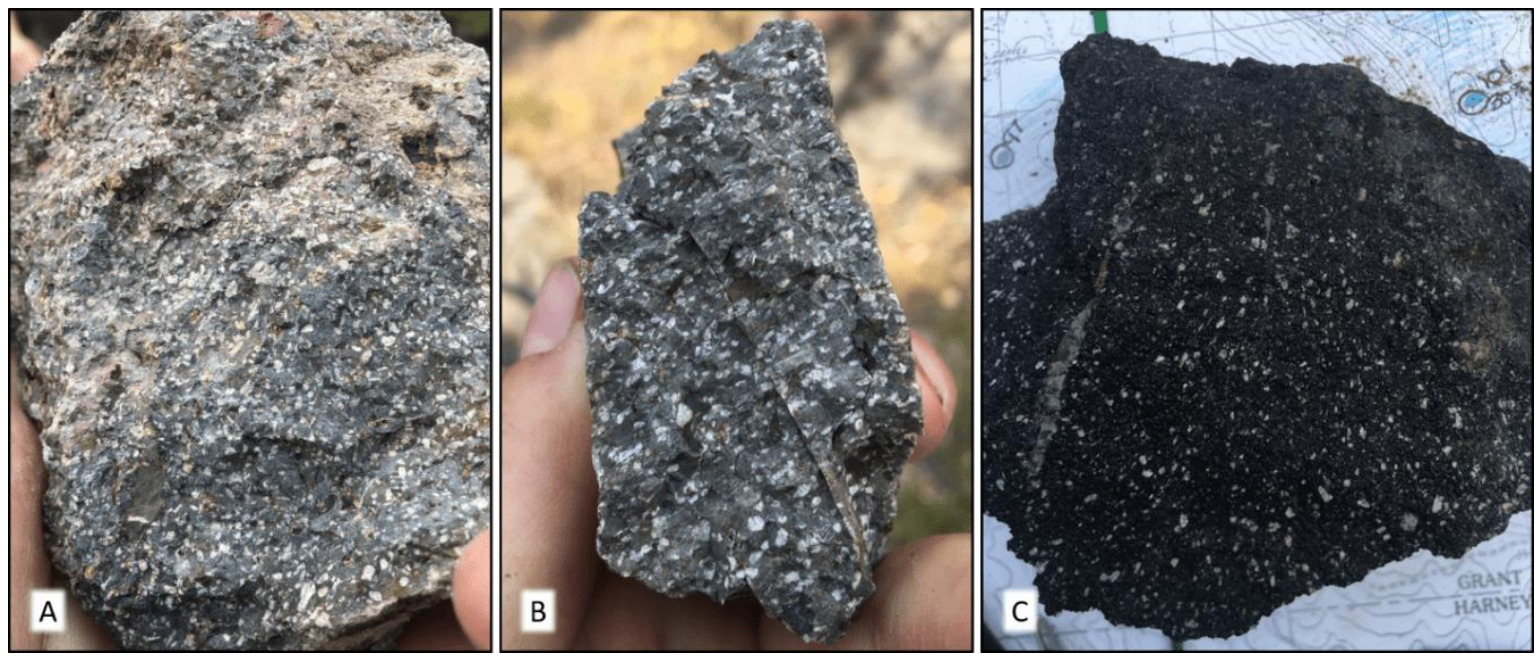

Figure 75: Wolf Mountain rhyolite in hand sample. From (A) to (C), the samples go from non-glassy to glassy. Each variety is of the $30 \%$ phenocryst-rich variety found in the Jump-off Joe Mountain quadrangle. 


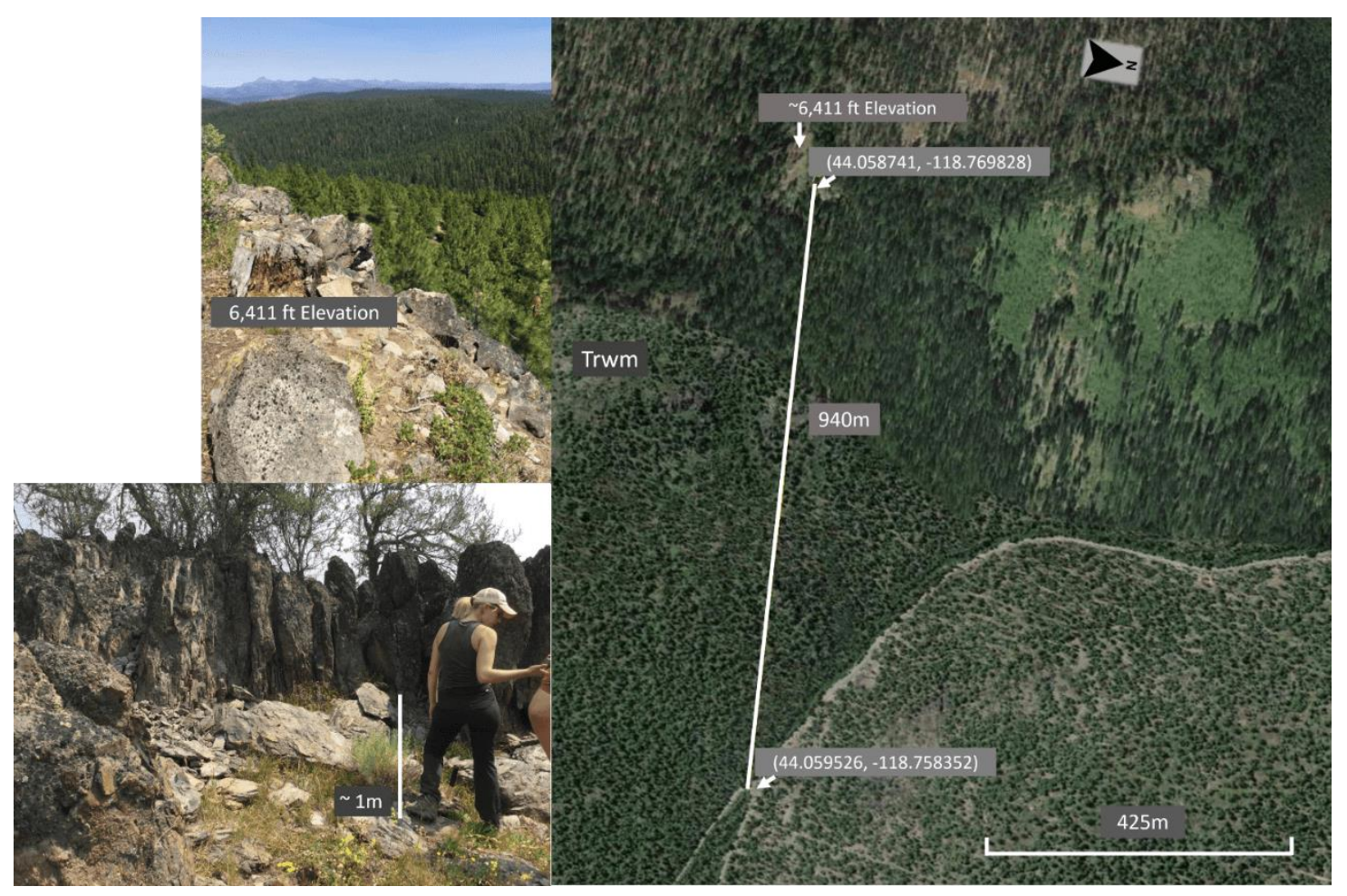

Figure 76: Photos are all from the Rhyolite of Wolf Mountain and are indeed from the south-eastern side of Wolf Mountain in the JOJM quadrangle. The image on the right was generated using Google Earth using knowledge of this unit in the study area. The majority of Trwm crops out to the South in JOJM and the east in MPT quads. By using this model, the unit Trwm thickness measures about $940 \mathrm{~m}$. The sizeable, estimated thickness is partly due to the north-south trending fault that dips east and runs directly through this section. In addition, the exposed Trwm is exceptional due to the extensional faulting, exposing a prominent face of Trbc. A typical unit outcrop thickness, however, remains rather large, ranging from $50-200 \mathrm{~m}$.

In the thin section (Figure 77), flow banding is visible in the groundmass. Phenocrysts consisted of large plagioclase (clearly seen in the hand sample) and some altered pyroxene. Pyroxene crystals are fresh in glassy samples. The groundmass can be glassy or devitrified. This unit does not contain amphibole, which distinguishes it from unit Trbc. In the north of JOJM, very glassy Trwm crops out. In thin section, the sample CD1883 exhibits fresh pyroxene and perlitic cracks. Trwm has a silica content of 73 wt. $\% \mathrm{SiO} 2$, and the highest 
overall Sr contents are yielding an average of $\sim 284 \mathrm{ppm} \mathrm{Sr}$ (represented in Plot D of Figure 49), inferring that Trwm is the least fractionated SR unit.

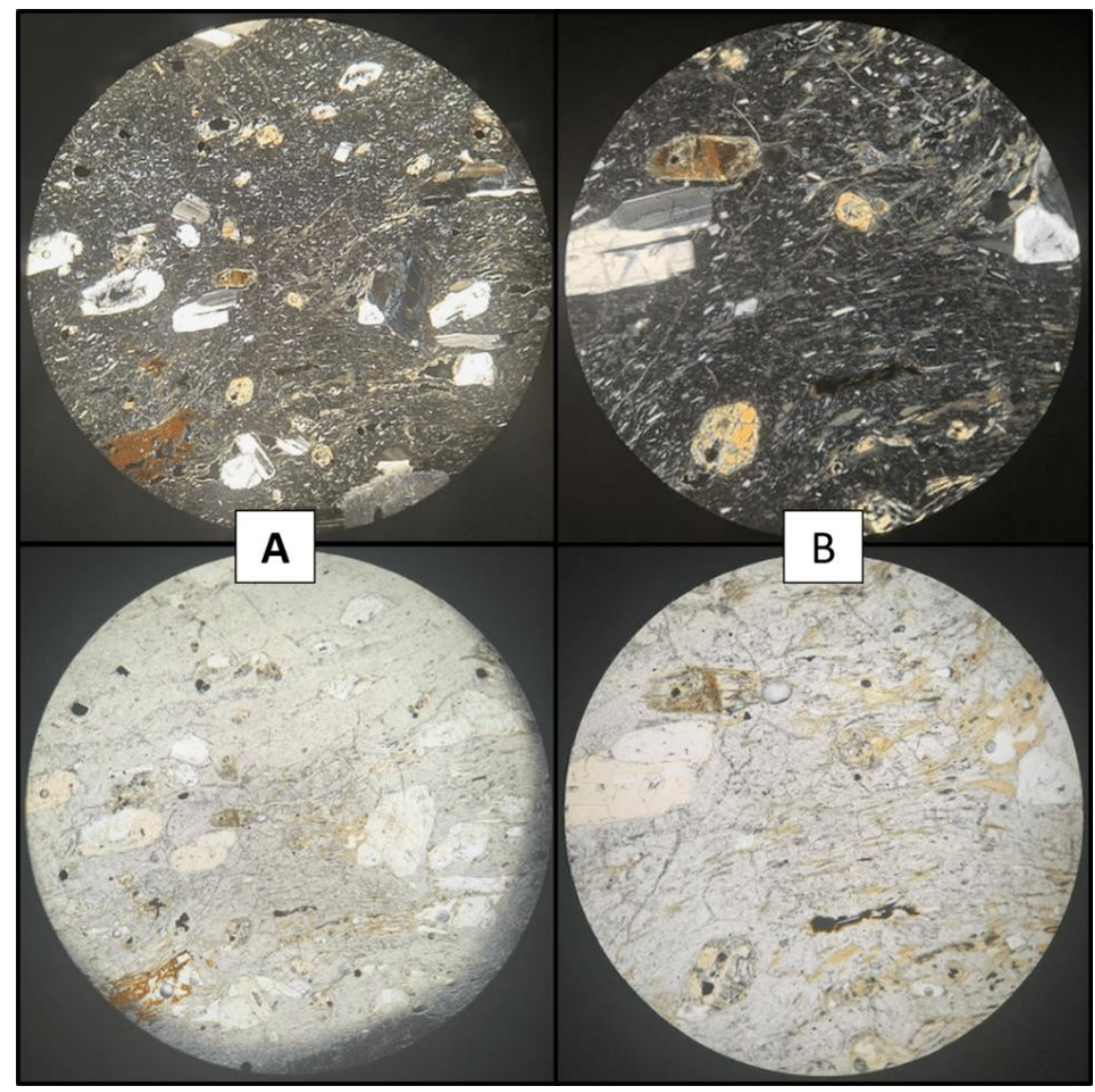

Figure 77: Thin section images from sample CD1964. The top row exhibits XPL, while the bottom row is in PPL. Image (A) is in 40X optical zoom, with (B) in 100X optical zoom.

\subsection{DISTRIBUTION of RHYOLITES}

The Strawberry Rhyolites of this study cover a field-mapped area with a total sum of about $182 \mathrm{~km}^{2}$. However, the mapped areas likely do not capture the full original distribution. In Figure 78 and Table 1, I present the estimated original distribution area for each rhyolite unit. These estimated areas sum up to a total of $386 \mathrm{~km}^{2}$. Using these estimated areas from Table 1, the largest rhyolite unit is Wolf Mountain (Trwm), covering about $170 \mathrm{~km}^{2}$, followed 
by the rhyolite of Three Cabin Spring (Trtcs) at $\sim 158 \mathrm{~km}^{2}$. The smallest estimated area is from the rhyolite of Big Bend (Trbb), covering an area of about $8 \mathrm{~km}^{2}$. Trwm and Trtcs remain in close proximity to one another and make up the large central portion of the mapped region. The tuff of Milk Spring (Ttms) follows in the third-largest estimated area, at a value of about $140 \mathrm{~km}^{2}$. Ttms is widely distributed throughout the entire project area, yielding a relatively large overall area.

Table 1: Calculated distribution area, from largest to smallest of Strawberry rhyolitic units. The area in this table is based on the estimated size of each unit (Figure 78) and the geometry of the polygons generated in ArcMap from the final map produced from fieldwork in this study.

$$
\text { Unit Name } \quad \text { Rhyolite Area Distribution }(\mathrm{Km} 2)
$$

\begin{tabular}{llcl}
\hline Trwm & Wolf Mountain Rhyolite & 170 & Largest Area \\
Trtcs & Three Canyon Spring Rhyolite & 157 \\
Ttms & Milk Spring Tuff & 139 \\
Trews & Elk Wallow Spring Rhyolite & 73 \\
Trac & Antelope Creek Rhyolite & 69 \\
Trcc & Canyon Creek Rhyolite & 58 \\
Trbc & Bridge Creek Rhyolite & 54 \\
Trks & Kent Spring Rhyolite & 51 \\
Trbs & Buckhorn Spring Rhyolite & 9.9 \\
Trbb & Big Bend Rhyolite & 7.6
\end{tabular}



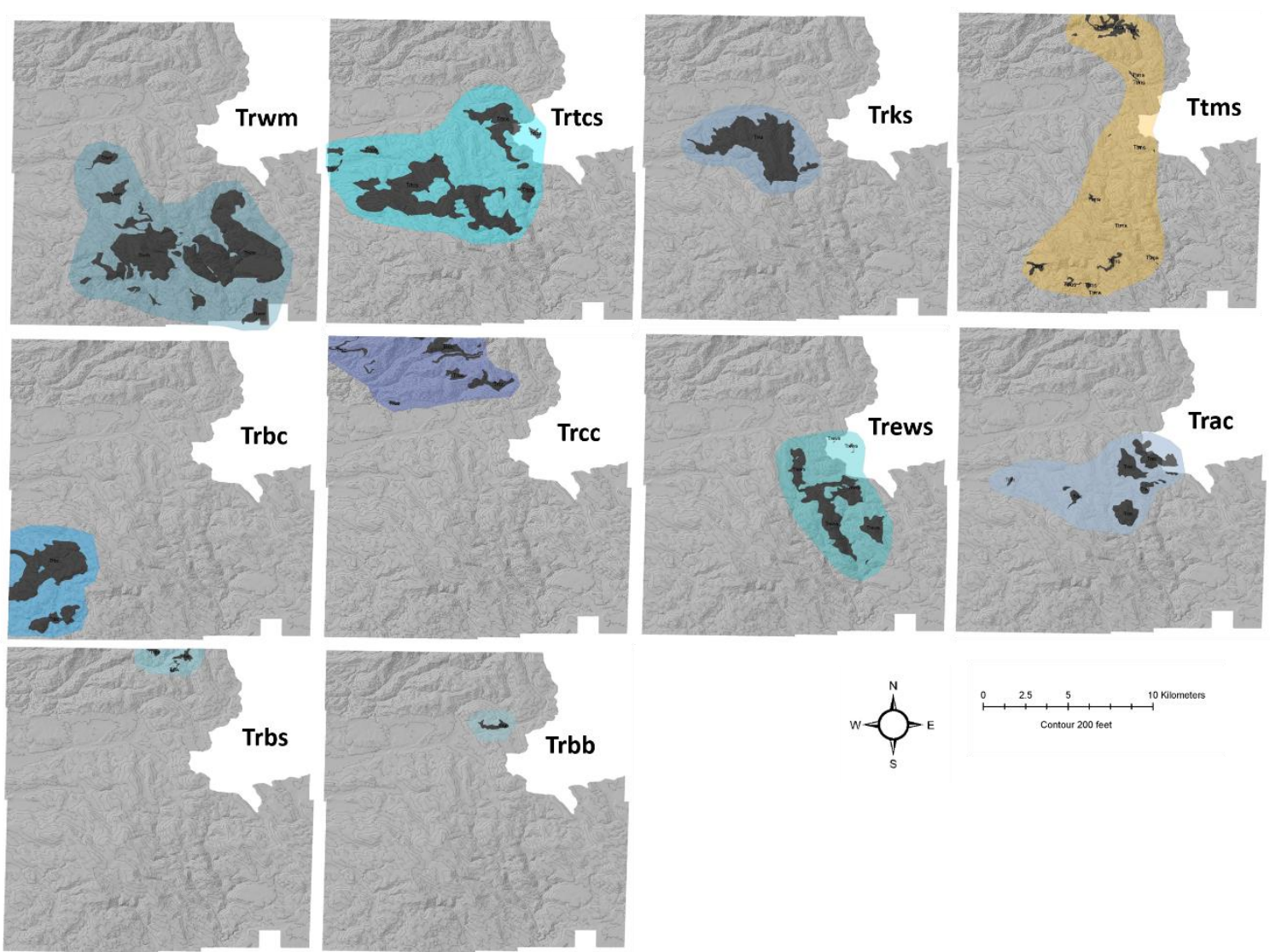

Figure 78: This study's estimated original coverage of each Strawberry rhyolite unit (in color) superimposed on the mapped extent (black). 


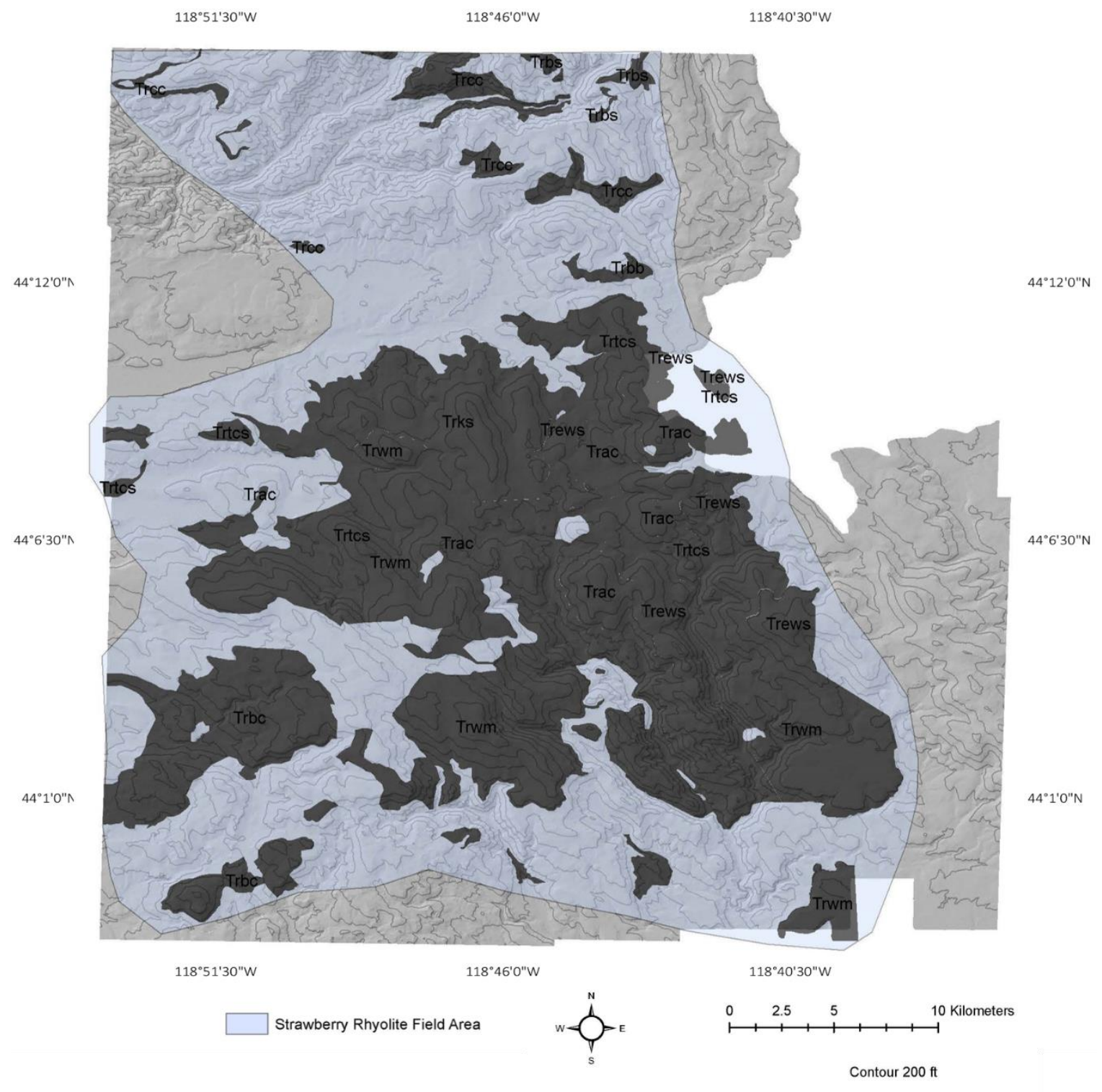

Figure 79: Geologic map showing rhyolite outcrops in dark gray and estimated original coverage of all rhyolite units of this study (in color). Dvorak conducted the mapping of the quadrangles Big Canyon and Jump-off Joe Mountain, and current PSU graduate student Rachel Sweeten mapped the Logan Valley West and Magpie Table quadrangles. 
Table 2: This area and volume table is produced by compiling all the field mappings of each Strawberry rhyolite unit, generating an estimated area polygon surrounding all those units, and calculating its overall geometry in ArcMap; the area is outlined in red. Then using this geometry with field compiled data, an estimated volume is produced.

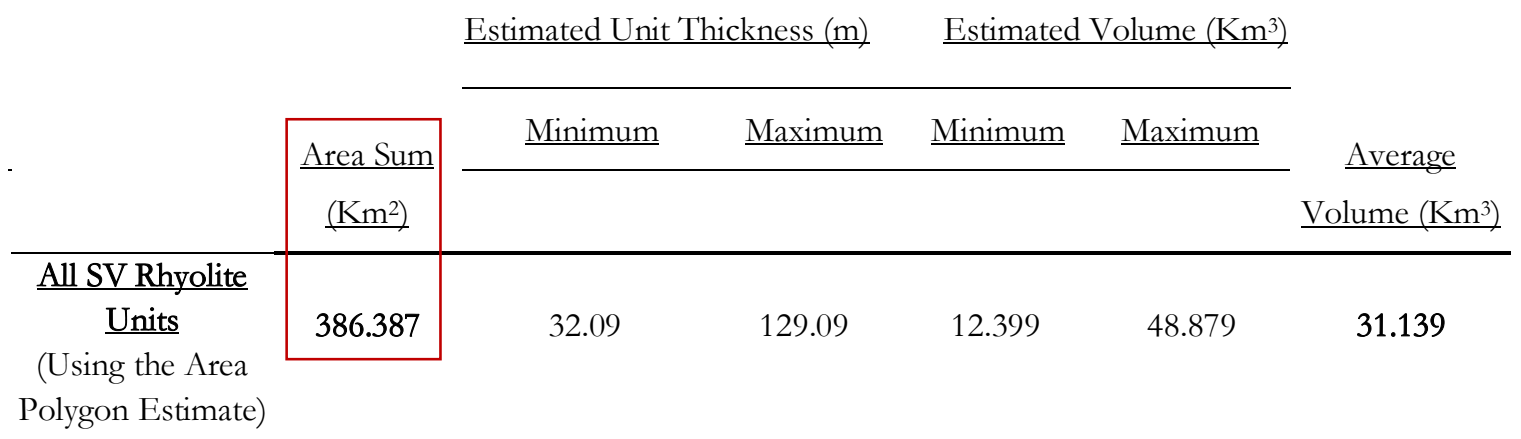

\subsection{AGE of STRAWBERRY RHYOLITES}

Age dates generated through this study and previously acquired (Steiner \& Streck 2013) are used in combination with stratigraphic field control to place rhyolite units into an eruptive sequence (Table 3). The rhyolite of Wolf Mountain is the oldest, dating to $16.16 \pm 0.17 \mathrm{Ma}$, and currently, the youngest age acquired is for the rhyolite of Kent Spring at the age of 14.37 $\pm 0.02 \mathrm{Ma}$ (Table 4). However, some rhyolites are clearly intercalated with andesite lavas of the Strawberry Volcanics, and these are the rhyolite of Buckhorn Spring and the rhyolite of Big Bend. Thus, these units are likely to be slightly younger than our youngest radiometric age. Also, some radiometric ages of different units overlap, which means that the eruptive sequence is unresolvable with available ages or that rhyolite is partially co-erupted. In general, however, the eruptive activity of the Strawberry Rhyolites is currently constrained to span a period of about 2 million years, ranging from around 16 to $14 \mathrm{Ma}$. 
Table 3: Compilation of ${ }^{40} \mathrm{Ar} /{ }^{39} \mathrm{Ar}$ age dates of Strawberry rhyolite units found in this project mapped region. Unit abbreviations are elaborated by unit names in Table 1, or the legend of the project map found in the appendix.

\begin{tabular}{|c|c|c|c|c|c|c|c|c|}
\hline $\begin{array}{c}\text { Quad } \\
\text { Location }\end{array}$ & $\begin{array}{l}\text { Sample } \\
\text { ID }\end{array}$ & $\begin{array}{c}\text { Unit } \\
\text { Abbreviation }\end{array}$ & Unit Name & Age (Ma) & Latitude & Longitude & Methods & Reference \\
\hline $\begin{array}{l}\text { Jump-Off Joe } \\
\text { Mountain }\end{array}$ & SV-151 & Trwm & $\begin{array}{c}\text { Wolf Mountain } \\
\text { Rhyolite }\end{array}$ & $16.16 \pm 0.17$ & $44^{\circ} 3^{\prime} 32.90^{\prime \prime}$ & $118^{\circ} 45^{\prime} 14.00^{\prime \prime}$ & Plateau & $\begin{array}{c}\text { Steiner \& } \\
\text { Streck, } 2013\end{array}$ \\
\hline $\begin{array}{l}\text { Jump-Off Joe } \\
\text { Mountain }\end{array}$ & SV-144 & Trwm & $\begin{array}{l}\text { Wolf Mountain } \\
\text { Rhyolite }\end{array}$ & $15.34 \pm 0.52$ & $44^{\circ} 4^{\prime} 42.80^{\prime \prime}$ & $118^{\circ} 45^{\prime} 12.99^{\prime \prime}$ & Plateau & $\begin{array}{c}\text { Steiner \& } \\
\text { Streck, } 2013\end{array}$ \\
\hline $\begin{array}{l}\text { Jump-Off Joe } \\
\text { Mountain }\end{array}$ & MS-17-05 & Trwm & $\begin{array}{c}\text { Wolf Mountain } \\
\text { Rhyolite }\end{array}$ & $15.002 \pm 0.047$ & 44.065 & -118.793 & Single Crystal & This Study \\
\hline $\begin{array}{l}\text { Jump-Off Joe } \\
\text { Mountain }\end{array}$ & JJ-17-8 & Trbc & $\begin{array}{c}\text { Bridge Creek } \\
\text { Rhyolite }\end{array}$ & $14.386 \pm 0.032$ & 44.016 & -118.855 & Single Crystal & This Study \\
\hline $\begin{array}{l}\text { Southwest of } \\
\text { JOJM }\end{array}$ & SV-173 & Trbc & $\begin{array}{c}\text { Bridge Creek } \\
\text { Rhyolite }\end{array}$ & $14.7 \pm 0.13$ & $44^{\circ} 3^{\prime} 46.80^{\prime \prime}$ & $118^{\circ} 51^{\prime} 51.80^{\prime \prime}$ & Plateau & $\begin{array}{c}\text { Steiner \& } \\
\text { Streck, } 2013\end{array}$ \\
\hline Big Canyon & CD1975 & Trks & $\begin{array}{c}\text { Kent Spring } \\
\text { Rhyolite }\end{array}$ & $14.37 \pm 0.02$ & 44.1639 & -118.79323 & Single Crystal & This Study \\
\hline Big Canyon & MS-14-23 & Trtcs & $\begin{array}{l}\text { Three Cabin } \\
\text { Spring Rhyolite }\end{array}$ & $14.81 \pm 0.04$ & 44.1734 & -118.7539 & Plateau & This Study \\
\hline Big Canyon & SV-179 & Trec & $\begin{array}{c}\text { Canyon Creek } \\
\text { Rhyolite }\end{array}$ & $15.30 \pm 0.10$ & $44^{\circ} 14^{\prime} 15.30^{\prime \prime}$ & $118^{\circ} 46^{\prime} 43.10^{\prime \prime}$ & Plateau & $\begin{array}{c}\text { Steiner \& } \\
\text { Streck, } 2013\end{array}$ \\
\hline Big Canyon & SV-190 & Trce & $\begin{array}{c}\text { Canyon Creek } \\
\text { Rhyolite }\end{array}$ & $14.79 \pm 0.17$ & $44^{\circ} 13^{\prime} 25.40^{\prime \prime}$ & $118^{\circ} 46^{\prime} 8.10^{\prime \prime}$ & Plateau & $\begin{array}{c}\text { Steiner \& } \\
\text { Streck, } 2013\end{array}$ \\
\hline
\end{tabular}

Table 4: The Strawberry Rhyolite units are listed according to age, from oldest to youngest. Unit abbreviations are elaborated by unit names in Table 1, or the legend of the project map found in the appendix.

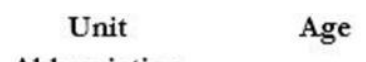

Abbreviation

\begin{tabular}{llc}
\hline O1dest & Trwm & $16.16 \pm 0.17$ \\
& Trwm & $15.34 \pm 0.52$ \\
& Trcc & $15.30 \pm 0.10$ \\
& Trwm & $15.002 \pm 0.047$ \\
& Trtcs & $14.81 \pm 0.04$ \\
& Trcc & $14.79 \pm 0.17$ \\
& Trbc & $14.7 \pm 0.13$ \\
& Trbc & $14.386 \pm 0.032$ \\
& Trks & $14.37 \pm 0.02$
\end{tabular}




\subsection{DISCUSSION}

\subsection{VOLUME ESTIMATES}

To calculate the volume of each SR unit, the thickness of each respective unit is required. Unit thicknesses were discerned in the field; however, there are considerable uncertainties. Sometimes a whole mountain, e.g., Bridge Creek Rhyolite in Figure 73, comprises one rhyolite unit. In other cases, actual outcrops are not thicker than a few meters. Given these observations, first, I chose a minimum and maximum thickness for each unit based on notes taken in the field and outcrop images with scale, also, through using the measuring tool on Google Earth to get a range of outcrop exposure along with using in-depth knowledge of the field region throughout the years of mapping the area and choosing sitespecific areas with precise one unit exposure. Once the range is discerned, the field evidence is combined with thicknesses in the literature of other youthful (Pliocene and younger) rhyolite lavas and dome complexes. The estimated area for each rhyolite unit (Figure 78) is multiplied by the minimum and maximum thicknesses, which yields volume estimates for each unit. In Table 5, units are listed according to their estimated distribution from largest to smallest based on the above methods. The values obtained were found using the average of the minimum and maximum unit thicknesses multiplied by their respective calculated estimated areas (Table 6). By clearly defining a volume for each unit gives a better representation closer to their actual distributions. The largest volume is obtained for the rhyolite of Wolf Mountain (Trwm), with a value of $\sim 21 \mathrm{~km}^{3}$. Trtcs follows Trwm with an average volume of $\sim 17 \mathrm{~km}^{3}$, both units undoubtedly producing the largest volume out of all the Strawberry rhyolites found in this study. The smallest volume average produced is from the rhyolite of Buckhorn Spring at a value of about $0.7 \mathrm{~km}^{3}$. More interpretations have been conducted regarding unit age dates 
and their volume relationship in understanding each of the Strawberry rhyolite unit's estimated volume.

Table 5: Calculated volume of Strawberry rhyolitic units, from largest to smallest. The volumes are calculated using each unit thickness multiplied by their respective area.

\section{Unit Name}

\author{
Estimated Volume \\ Average $\left(\mathrm{Km}^{3}\right)$
}

\begin{tabular}{llll}
\hline Trwm & Wolf Mountain Rhyolite & 21.251 & Largest Volume \\
Trtcs & Three Canyon Spring Rhyolite & 16.001 & $\uparrow$ \\
Trews & Elk Wallow Spring Rhyolite & 8.797 & \\
Trks & Kent Spring Rhyolite & 6.203 & \\
Trcc & Canyon Creek Rhyolite & 4.523 & \\
Trbc & Bridge Creek Rhyolite & 3.839 & \\
Trac & Antelope Creek Rhyolite & 3.466 & \\
Ttms & Milk Spring Tuff & 2.445 & \\
Trbb & Big Bend Rhyolite & 0.908 & \\
Trbs & Buckhorn Spring Rhyolite & 0.696 & Smallest Volume
\end{tabular}


Table 6: Calculated volumes of each SR unit based on the estimated area (see Table 1) and their respective unit maximum and minimum thicknesses that were discerned from fieldwork components and observations from well-preserved rhyolite lavas.

\begin{tabular}{|c|c|c|c|c|c|c|c|}
\hline & \multirow[t]{2}{*}{ Unit Name } & \multirow{2}{*}{$\begin{array}{l}\text { Area Sum } \\
\left(\mathrm{Km}^{2}\right)\end{array}$} & \multicolumn{2}{|c|}{ Estimated Unit Thickness (m) } & \multicolumn{2}{|c|}{ Estimated Volume $\left(\mathrm{Km}^{3}\right)$} & \multirow{2}{*}{$\begin{array}{c}\text { Average } \\
\text { Volume }\left(\mathrm{Km}^{3}\right)\end{array}$} \\
\hline & & & Minimum & Maximum & Minimum & Maximum & \\
\hline Ttms & Milk Spring Tuff & 139.729 & 5 & 30 & 0.699 & 4.192 & 2.445 \\
\hline Trbs & $\begin{array}{c}\text { Buckhorn Spring } \\
\text { Rhyolite }\end{array}$ & 9.937 & 20 & 120 & 0.199 & 1.192 & 0.696 \\
\hline Trbb & Big Bend Rhyolite & 7.567 & 40 & 200 & 0.151 & 0.303 & 0.908 \\
\hline Trbc & $\begin{array}{c}\text { Bridge Creek } \\
\text { Rhyolite }\end{array}$ & 54.839 & 40 & 100 & 2.194 & 5.484 & 3.839 \\
\hline Trews & $\begin{array}{c}\text { Elk Wallow Spring } \\
\text { Rhyolite }\end{array}$ & 73.311 & 40 & 200 & 2.932 & 14.662 & 8.797 \\
\hline Trks & $\begin{array}{l}\text { Kent Spring } \\
\text { Rhyolite }\end{array}$ & 51.692 & 40 & 200 & 2.068 & 10.338 & 6.203 \\
\hline Trac & $\begin{array}{c}\text { Antelope Creek } \\
\text { Rhyolite }\end{array}$ & 69.313 & 30 & 70 & 2.079 & 4.852 & 3.466 \\
\hline Trce & $\begin{array}{c}\text { Canyon Creek } \\
\text { Rhyolite }\end{array}$ & 64.618 & 40 & 100 & 2.585 & 6.462 & 4.523 \\
\hline Trtcs & $\begin{array}{l}\text { Three Canyon } \\
\text { Spring Rhyolite }\end{array}$ & 145.468 & 40 & 180 & 5.819 & 26.184 & 16.001 \\
\hline Trwm & $\begin{array}{l}\text { Wolf Mountain } \\
\text { Rhyolite }\end{array}$ & 170.007 & 50 & 200 & 8.500 & 34.001 & 21.251 \\
\hline \multirow[t]{3}{*}{ Tmus } & $\begin{array}{l}\text { Mullen Spring } \\
\text { Volcanic Clastics }\end{array}$ & 7.460 & 8 & 20 & 0.060 & 0.149 & 0.104 \\
\hline & & & & & & $\begin{array}{l}\text { Volume Sum } \\
\text { (Maximum) }\end{array}$ & $\begin{array}{l}\text { Volume Sum } \\
\text { (Average) }\end{array}$ \\
\hline & & & & & & 109.031 & 68.234 \\
\hline
\end{tabular}




\subsection{TEMPORAL CHANGES in MINERALOGY and COMPOSITION of RHYOLITES}

The spectrum of Strawberry Rhyolites erupted from crystal-rich to aphyric, from pyroxene as the only mafic phase to having units containing only biotite or amphibole. With some units ranging from containing only plagioclase to those with plagioclase and quartz. The Strawberry Rhyolite units have been divided into two groups based on their lithology, petrography, and composition. With nine specific units making up the Strawberry Rhyolites, seven results in the aphyric and phenocryst poor unit group. The last two rhyolite units make up the second group category, which is the phenocryst rich units. The primary criteria for the units to fall into the aphyric and phenocryst poor category is having a phenocryst percentage range from aphyric to $4 \%$. These units also fall within a silica content range of $70.4-77.4$ wt.- $\% \mathrm{SiO}^{2}$. For a unit to be categorized as a phenocryst-rich unit, its plagioclase phenocryst percentage will range from $10-30 \%$, with other phenocrysts ranging from $1-5 \%$. The following other phenocryst types are most commonly found to be biotite, amphibole, pyroxene (mostly orthopyroxene). The silica content for this rhyolite category has been found to remain a steady 73 wt. $-\% \mathrm{SiO}^{2}$.

Compositions range from low silica rhyolite $\left(\sim 71\right.$ wt. $\left.\% \mathrm{SiO}_{2}\right)$ to high silica rhyolites (up to a max value of 77.7 wt. $\mathrm{SiO}_{2}$, (cf. Hildreth, 1981). Values above 77.7 wt. $\%$ are likely an artifact of a slight $\mathrm{SiO}_{2}$ gain during devitrification. This range from low- to high-silica rhyolites clearly preserves a record of being progressively more differentiated (evolved) as elements that are compatible with crystallizing mineral assemblage generally decrease with increased silica, to clearly define the Strawberry Rhyolites temporal changes and the understanding of their 
trace elements and how they affect the petrogenetic process. Examples for this are seen in the variation plots; $\mathrm{Fe}, \mathrm{Ti}, \mathrm{Sr}$, and $\mathrm{Eu}$ (or better $\mathrm{Eu} / \mathrm{Eu}^{*}$ ).

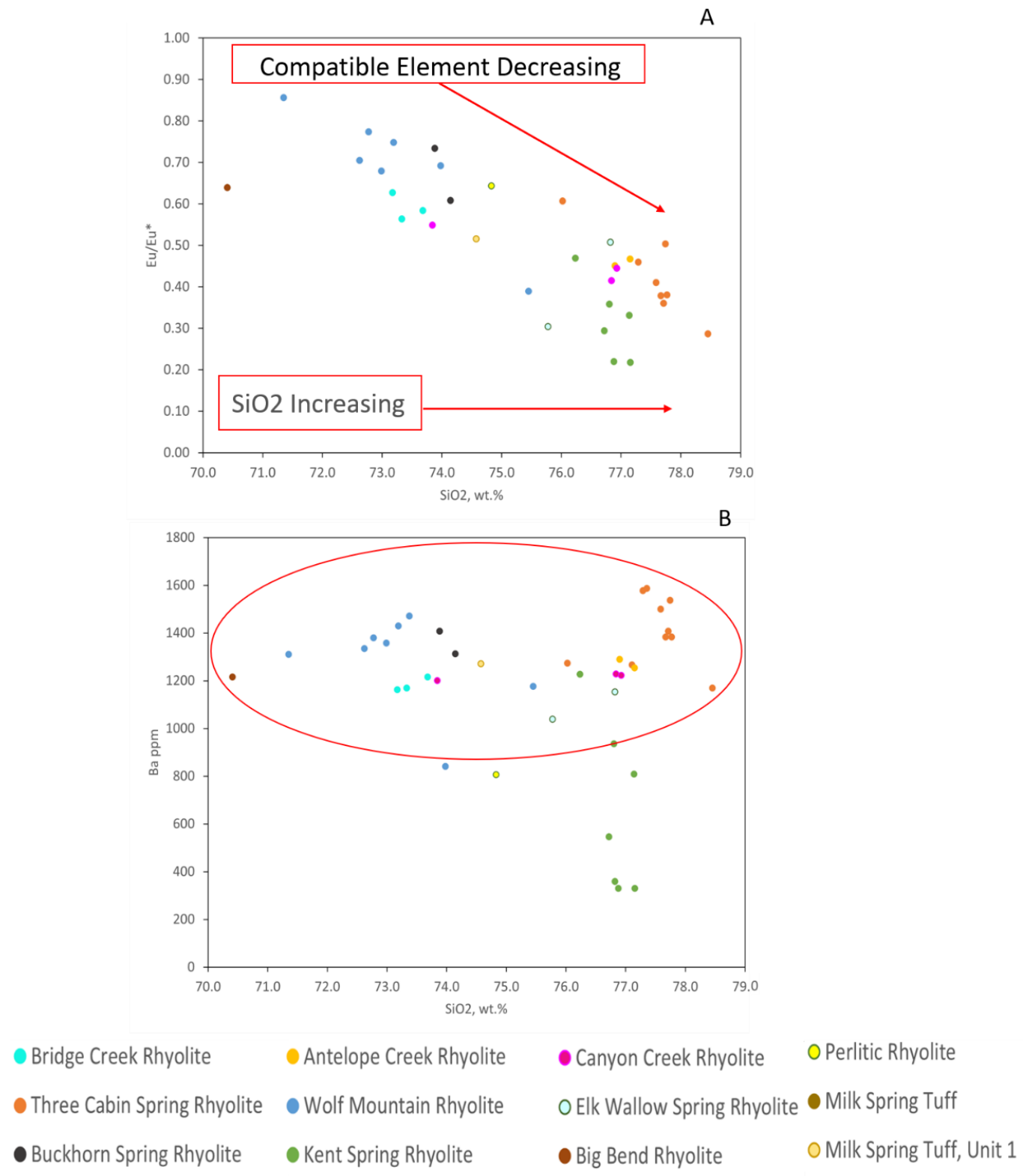

Figure 80: Plot (A) is a variation diagram for $\mathrm{Eu} / \mathrm{Eu}^{*}$ vs. SiO2 wt.\% for the Strawberry Rhyolites, highlighting the trend of as silica increases the compatible element (Eu) decrease. Plot (B) is also a variation diagram, highlighting the trace element $\mathrm{Ba}$ versus silica content. Circled in red, most of the units have a high $\mathrm{Ba}$ value (exception of Trks). This high concentration indicates how compatible they are-the higher the $\mathrm{Ba}$, the stronger the compatibility in alkali feldspar. 
The Eu/Eu* vs. SiO2 wt. \% variation plot (plot A in Figure 80) demonstrates a trend in that as the silica content increases, the compatible trace element europium decreases. Using plot $\mathrm{A}, \mathrm{Eu} / \mathrm{Eu}^{*}$, the quantitative expression for the Eu anomaly is portrayed in rare earth element diagrams. The Eu anomaly is predominantly controlled by feldspars, as europium is a compatible trace element in plagioclase and alkali feldspar. To calculate the Eu/Eu* ratio correctly, the chondrite normalized values are required for the elements $\mathrm{Eu}, \mathrm{Sm}$, and $\mathrm{Gd}$. Eu* is calculated by example in Equation 1 below.

$$
E u^{*}=\sqrt{ }(S m \times G d)
$$

Equation 1

The Eu* expression represents where the original value would sit if no depletion has occurred. By dividing the chondrite normalized value for $\mathrm{Eu}$ by the found $\mathrm{Eu}^{*}$ value, a value should equal a number between zero and one. Values that are closer to the number one represent the smaller the Eu anomaly. However, if values fall more towards zero, then the greater the Eu anomaly. This interpretation is represented in the Strawberry Rhyolite phenocryst rich units (Trbc and Trwm), plotting high (closer to one) Eu/Eu* values. Having a high value means these units are less evolved. Therefore, the phenocryst-rich units did not experience significant feldspar fractionation for the appropriate elements to be removed from the melt, determining how they affect the rhyolitic petrogenetic process.

Crystal-rich units such as Trwm and Trbc contain plagioclase that is often complexly zoned, a noteworthy observation as plagioclase phenocrysts in crystal poor units are much more straightforward. Complexly zoned plagioclase phenocrysts may be a result of partial melting. Based on their regional geologic history, they are more likely a product of partial 
melting, recycled from older rocks that underwent a partial melting process to produce the rhyolites. So, the temporal change appears to indicate the starting up of a rhyolite field by erupting crystal-rich units which are transitioning to a mature stage where units are more crystal poor either or the complex plagioclase has been completely resorbed, or the rhyolite magma is no longer in contact with the source or country rocks containing such plagioclase. Interestingly, in plot B in Figure 80, the trace element barium values stay high, indicating that indeed alkali feldspar has not begun crystallizing ( $\mathrm{Ba}$ is strongly compatible with alkali feldspar), except for the rhyolite of Kent Spring. Trks indicate decreasing barium, suggesting that this unit experienced more feldspar fractionation, as barium substitutes for potassium in potassium feldspar, hornblende, and biotite.

To further understand these implications of the temporal changes in the Strawberry Rhyolites, the $\mathrm{Nb}$ vs. Zr variation diagram (Figure 48) is used to classify samples as I-type or A-type using the discrimination techniques of Whalen et al., 1987. By applying the parameters that distinguish A- from I-type rhyolites (e.g., Whalen et al., 1987; Streck, 2014), and using the variation diagrams that involve the elements $\mathrm{Nb}, \mathrm{Zr}$, the $\mathrm{La} / \mathrm{Yb}$ ratio, and the sum of $\mathrm{Zr}+\mathrm{Nb}+\mathrm{Y}+\mathrm{Ce}$, indicate variations amongst the Strawberry Rhyolites (as seen in plots $\mathrm{E}$ and F in Figure 49, along with $\mathrm{J}$ and $\mathrm{H}$ in Figure 50). Similar variations have been observed at other single Miocene rhyolite centers elsewhere in Oregon (e.g., Large, 2016; Brown, 2017; Young 2020). In general, lower silica, crystal-rich units such as Trwm and Trbc erupted early, while the more crystal poor and silica-rich units were more prevalent later. Units that indicate a slight trend towards A-type compositions, such as Trbs, Trks, and the rhyolitic portion of Ttms, erupted the latest. The development of the rhyolites with slightly more of an A-type composition follow this sequence, which is compatible with the interaction of basalt intruding 
into crust, thus initiating partial melting. The production of these A-type rhyolites, combined with ramping up the heat input from basalt, supports near-liquidus rhyolite liquids. Interaction of basalts with rhyolites culminates in the production of A-type like rhyolites, supporting the association with hot spot activity. Evidence for this stage also comes from the commingling of mafic and rhyolitic magmas to produce the tuff of Milk Spring. Because we now have an understanding of the Strawberry Rhyolite units' temporal change in terms of their mineralogy and composition, we can use this to interpret petrographic relationships.

The Strawberry rhyolite field is significant as it covers an approximate area of $386 \mathrm{~km}^{2}$ with an averaged overall volume of about $67 \mathrm{~km}^{3}$ and spanning a constrained period of 2 million years. Figure 81 relates volume versus age for the Strawberry Rhyolites. The trend depicted is that as the rhyolites younger, the smaller the volume they produce. This age and volume relationship may be a precursor in better determining stratigraphy of rhyolitic volcanic units, which aid in closing geologic time gaps throughout history. 


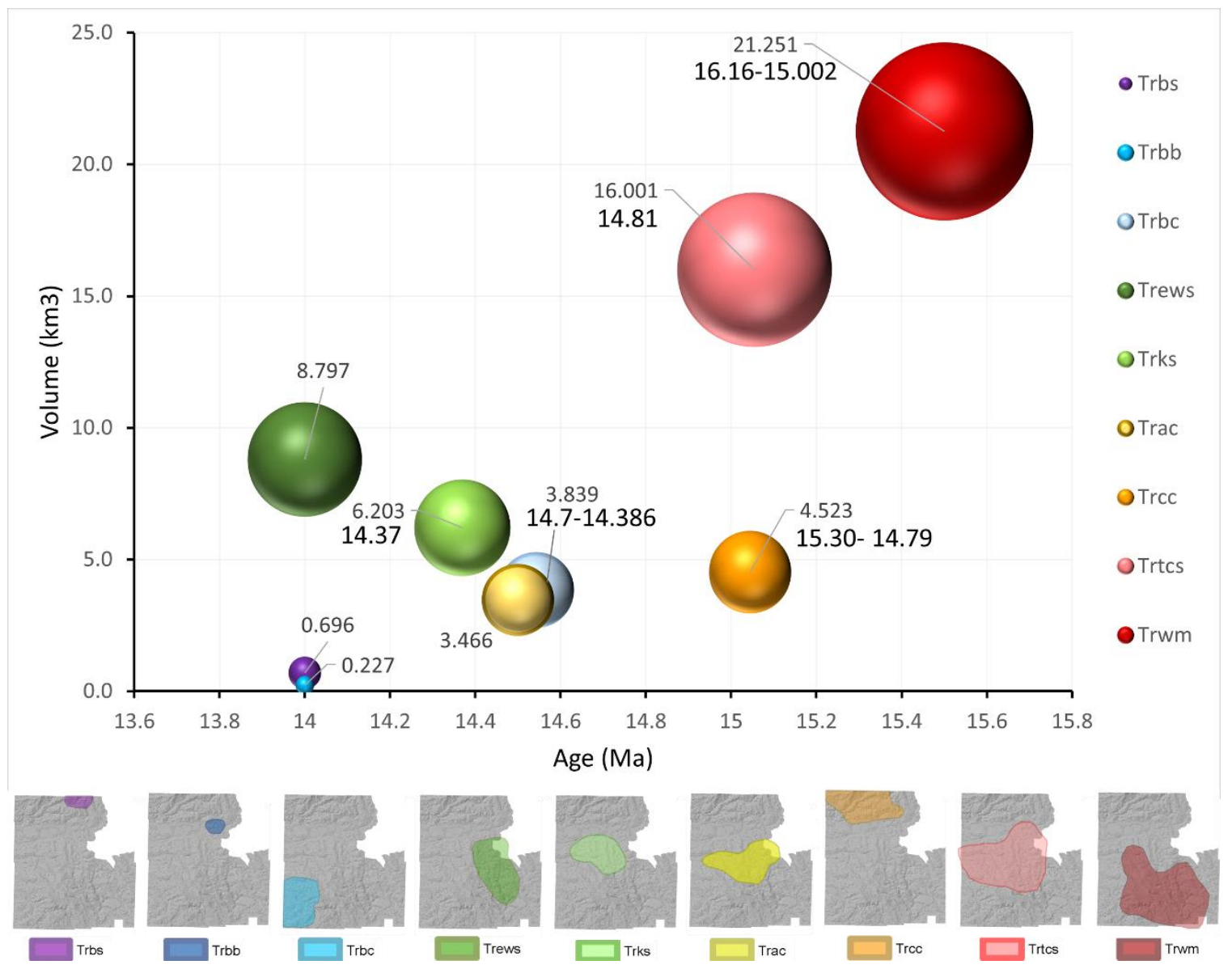

Figure 81: Estimated volume versus age plot of the Strawberry Rhyolites. This plot highlights how as the rhyolite units go from older to younger, they also trend towards larger to smaller regarding volume in size. The larger bold numbers on the plot are the age dates acquired, with the smaller numbers being their estimated volume. The map images below the graph highlight each specific unit's estimated area based on maps produced in the field area. 


\subsection{COMPARING the STRAWBERRY RHYOLITE FIELD with OTHER}

MIOCENE and YOUNGER RHYOLITE FLOWS and FIELDS

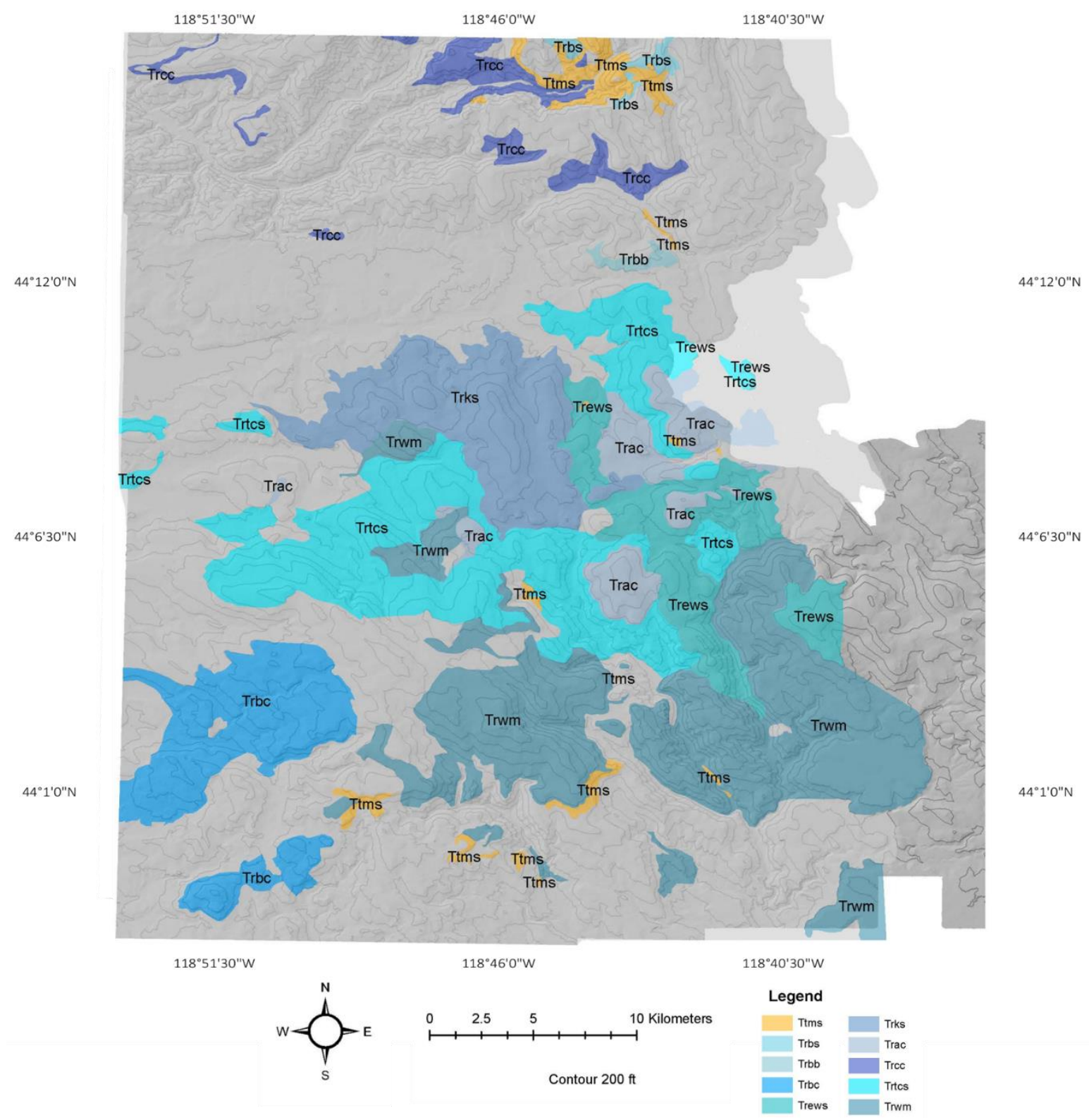

Figure 82: Map image incorporates all the rhyolite units or units with a rhyolite component (Ttms)) mapped in this project; all units that are not locally sourced rhyolites are greyed out. This map shows that the presence of rhyolite is more varied and extensive than previously mapped. 
This study demonstrates that the Strawberry Rhyolites constitute a significant rhyolite field that is among the largest in Oregon. Aerial coverage of approximately $386 \mathrm{~km}^{2}$ (Figure 79) and an overall estimated volume of $\sim 67 \mathrm{~km}^{3}$ using a median thickness for each unit. On the other hand, the total volume could be greater than $100 \mathrm{~km}^{3}$ if greater thicknesses apply. I want to highlight this by comparing the Strawberry rhyolite field to well-known rhyolite lava flows and fields.

The Big Obsidian Flow generated from the Newberry Volcano is a prominent single rhyolite lava flow that erupted about 2500 years ago (Sherrod et al., 1997). The Big Obsidian flow extends over less than $8 \mathrm{~km}^{2}$ (Newberry Volcano, 2021). This flow extended about 1.8 $\mathrm{km}$ long and is locally thicker than $\sim 20 \mathrm{~m}$ (Sherrod et al., 1997). The Glass Mountain rhyolites from the Medicine Lake Volcano cover an area of about $68 \mathrm{~km}^{2}$ with a volume of $1.0 \mathrm{~km}^{3}$ (Donnelly, 1990). Glass Buttes is a series of late Miocene rhyolite dome complexes of the central High Lava Plains of Oregon (Walker, 2006). The Glass Buttes cover an estimated area of $140 \mathrm{~km}^{2}$ (Stueber et al., 2015). According to Richard Roche's 1987 thesis, the exact volume is unknown, so we need to compile some data to get an idea. The flow nearest Musser Draw, south of Glass Butte, has a length $\sim 1 \mathrm{~km}$, a width of $0.25 \mathrm{~km}$, and a thickness of $15 \mathrm{~m}$. Then, little Glass Butte exposure area ranges from $5-8 \mathrm{~km}^{2}$. Lastly, the largest volume is said to belong to the high-silica rhyolite sequence of the Glass Buttes Complex, having a thickness of up to $600 \mathrm{~m}$ (Roche, 1987). I use the 15m value from the Musser Draw flow to calculate the average volume of the little glass butte exposure by assuming similar thicknesses, yield $\sim 0.1 \mathrm{~km}^{3}$. Then by averaging the two calculated areas (Musser Draw and Little Glass Butte), a calculated volume estimate for the high-silica rhyolite sequence yields $2.9 \mathrm{~km}^{3}$. Lastly, averaging all three flow areas and volumes, they amount to $\sim 5 \mathrm{~km}^{2}$ and $\sim 1 \mathrm{~km}^{3}$. 
The size of the Strawberry Rhyolite field discussed in this project is close to that of the Coso Volcanic Field in Inyo County, CA, in relative size. The area of this field is about 316 $\mathrm{km}^{2}$ - each unit from the Coso rhyolite field range in volume from 0.0003 to $0.3 \mathrm{~km}^{3}$. There are seven distinct rhyolite domes and flows (Bacon et al., 1981). The sum of each volume of these seven domes and flows amounts to about $1.58 \mathrm{~km}^{3}$. Volumes for individual units come from Bacon et al. (1981, Table 2. Figure 83 below shows a visual representation of these fields in comparison. 
$\sim 1,142 \mathrm{~km}^{2}$

Mahogany Mountain,

Three Fingers OR

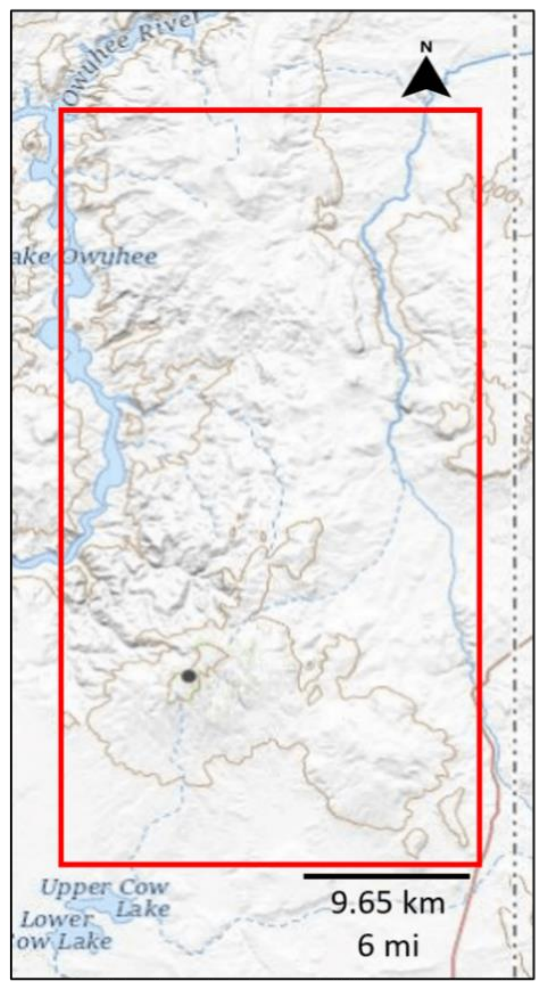

$\sim 140 \mathrm{~km}^{2}$

Glass Buttes

Complex OR

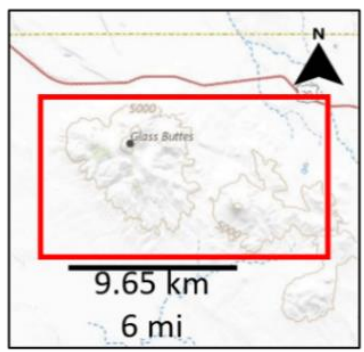

$\sim 386 \mathrm{~km}^{2}$

Strawberry Rhyolite

Field OR

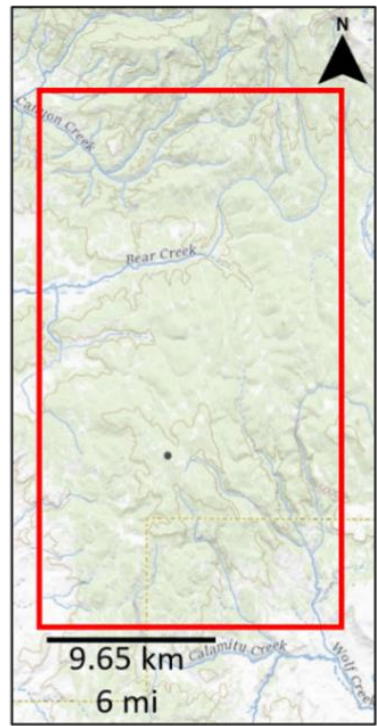

$\sim 68 \mathrm{~km}^{2}$

Glass Mountain,

Medicine Lake CA

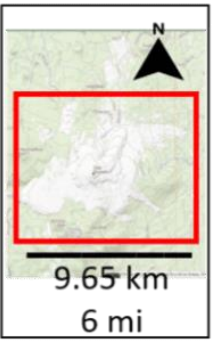

$\sim 316 \mathrm{~km}^{2}$

Coso Rhyolite

Field CA

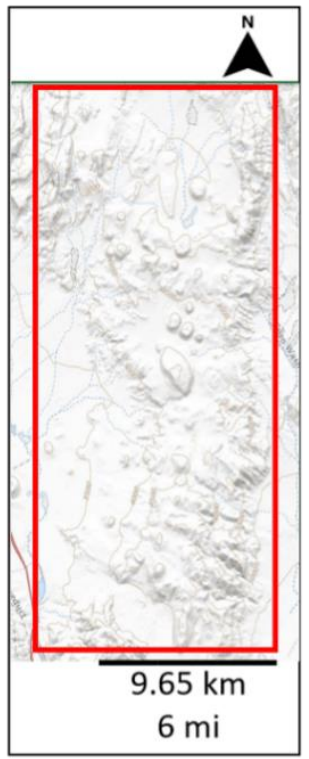

$\sim 8 \mathrm{~km}^{2}$

Big Obsidian Flow, Newberry OR

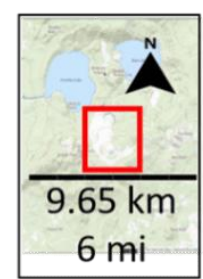

Figure 83: Figure representing a size comparison to the project area and other rhyolite fields. Each volcanic field is on the same scale to highlight its size differences. 


\subsection{CONCLUSION}

This study centered on a largely unknown mid-Miocene rhyolite field in the greater area of the Strawberry Mountains of eastern Oregon near the town of John Day. The existence of mid-Miocene rhyolites as part of the Strawberry Volcanics in this area was initially recorded by Robyn (1977). Still, little work was done to detail distribution and differentiated units based on age, composition, and mineralogy. Steiner (2016) provided more detail on stratigraphic position, composition, and overall distribution of the rhyolites but still leaving many unanswered questions. In the context of three USGS Edmap mapping projects, this study has revealed the actual areal distribution of rhyolite units of this field, volumetric estimates, and their stratigraphic, compositional, mineralogical makeup. A minimum of 9 distinct effusive rhyolite units erupted over a 2-million-year period in addition to one (possibly two) mixed, rhyolite-andesite pyroclastic deposit from $\sim 16.2$ to 14.3 Ma. These collectively make up the Strawberry Rhyolites. The estimated cumulative area of the rhyolites is $386 \mathrm{~km}^{2}$ with an estimated maximum volume of 111 $\mathrm{km}^{3}$. Rhyolites range from low-silica to high-silica composition and from phenocryst rich containing $>20 \%$ phenocryst to those that are aphyric. Most units display glassy-todevitrified lithologies. Mineral assemblages are dominated by plagioclase and mafic silicates, often containing amphibole, biotite, or both. Some units carry orthopyroxene in addition to or instead of biotite and amphibole. Strawberry rhyolites are intercalated with regional tuffs of the Dinner Creek Tuff. Although the youngest rhyolites co-erupted with basalts and andesites, they typically underlie basalt to andesites lavas of the Strawberry Volcanics. All lavas of the Strawberry Volcanics overlie pre-Cenozoic basement consisting of clastic sedimentary rocks regionally belonging to the Izee terrane and ultramafic rocks 
belonging to the Baker terrane. The mid-Miocene volcanic stratigraphy is capped by the widespread late Miocene Devine Canyon and Rattlesnake Tuff erupting from the Harney Basin to the south. Faulting was likely instrumental in forming numerous N-S trending valleys that dot this part of the Blue Mountains province. Quaternary fluvial processes incised canyons and caused several deep-seated landslides, resulting in this part of the Strawberry Mountains' present topography.

Strawberry Rhyolites are now recognized to belong to the rhyolite flare-up associated with the main pulse of the CRBG volcanism, with rhyolite centers occurring near the Oregon-Nevada state border in the south to Baker City in the north and as far northwest as the Strawberry Rhyolites. Thus, adding Strawberry Rhyolites to this rhyolite flare-up increased the footprint of this province towards the northwest. 


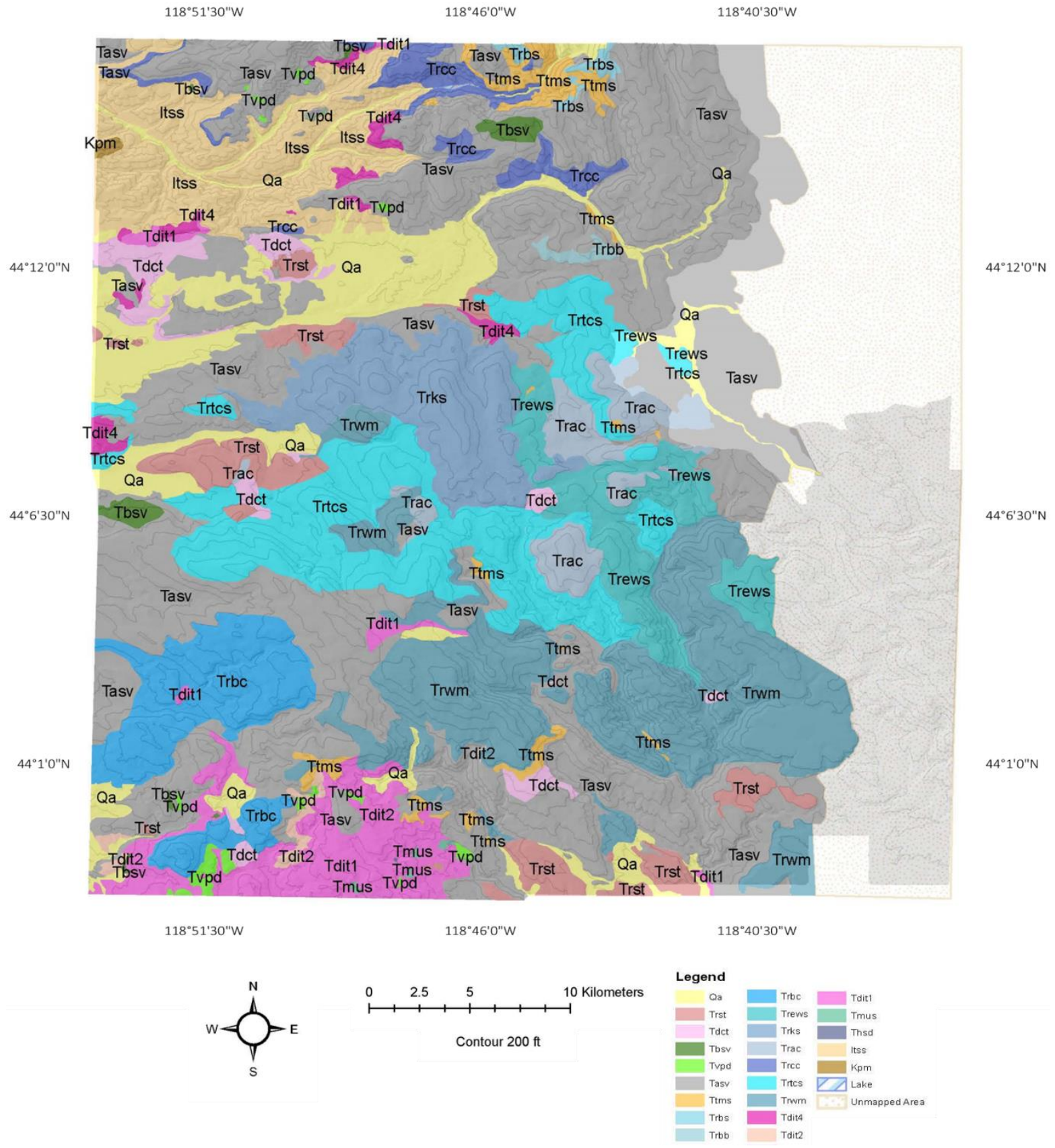

Figure 84: Geologic map produced through this study incorporates the geology of Jump-off Joe Mountain, Big Canyon, Logan Valley West, and Magpie Table quadrangles, depicting how various the area's units genuinely are. 


\subsection{REFERENCES}

Ambroz, Jessica A, Glascock, Michael D, \& Skinner, Craig E. (2001). Chemical Differentiation of Obsidian within the Glass Buttes Complex, Oregon. Journal of Archaeological Science, 28(7), 741-746. https://doi.org/10.1006/jasc.2000.0593

Bacon, Charles R, Macdonald, Ray, Smith, Robert L, \& Baedecker, Philip A. (1981). Pleistocene high-silica rhyolites of the Coso Volcanic Field, Inyo County, California. Journal of Geophysical Research: Solid Earth, 86(B11), 10223-10241. https://doi.org/10.1029/JB086iB11p10223

Baksi, AK, 1989, Reevaluation of the Timing and Duration of Extrusion of the Imnaha, Picture Gorge, and Grande Ronde Basalts, Columbia River Basalt Group, Geological Society of America Special Paper 239, p. $105-112$

Barry, T., Kelley, S., Reidel, S., Camp, V., Self, S., Jarboe, N., . . Renne, P. (2013, August 01). Eruption chronology of the Columbia River Basalt Group. Retrieved November 19, 2020, from https://pubs.geoscienceworld.org/books/book/661/chapter/3807104/Eruptionchronology-of-the-Columbia-River-Basalt

Benson, T.R. and Mahood, G.A., 2016, Geology of the Mid-Miocene Rooster Comb Caldera and Lake Owyhee Volcanic Field, eastern Oregon: Silicic volcanism associated with Grande Ronde flood basalt, Journal of Volcanology and Geothermal Research, v. 309, p. 96 117, doi:10.1016/j.jvolgeores.2015.11.011

Bestland, E. A., and G. J. Retallack (1994a), Geology and paleoenvironments of the Clarno Unit, John Day Fossil Beds National Monument, Oregon, U. S. Natl. Park Syst. Open File Rep., 160-211 pp.

Brooks, H. C., McIntyre, J. R., \& Walker, G. W. (1976). Geology of the Oregon part of the Baker $1^{\circ}$ by $2^{\circ}$ quadrangle: Oregon Department of Geology and Mineral Industries Geologic Map: Series Map GMS-7, scale 1:250,000. Retrieved 2019, from https://www.oregongeology.org/pubs/gms/GMS-007.pdf

Brown, C.E., and Thayer, T.P., 1966, Geologic map of the Canyon City quadrangle, northeastern Oregon: US Geological Survey, Miscellaneous Geologic Investigations Map I-447, scale 1:250,000.

Brown, E. A. (2017). Rhyolite Petrogenesis at Tower Mountain Caldera, OR (Order No.10285151). Available from Dissertations \& Theses @ Portland State University; ProQuest Dissertations \& Theses Global. (1949311147). http:/ / stats.lib.pdx.edu/proxy.php?url=http:// search.proquest.com.proxy.lib.pdx.ed $\mathrm{u} /$ dissertations-theses/rhyolite-petrogenesis-at-towermountaincaldera/docview/1949311147/se-2?accountid=13265

Cahoon, E.B., Streck, M.J., 2017, Picture Gorge Basalt, eastern Oregon: extended distribution And petrogenetic connections to Steens Basalt and Strawberry Volcanics. Geological Society of America Abstracts with Programs. Vol. 49, No. 6 doi: 10.1130/abs/2017AM-304582

Cahoon, Emily B, Streck, Martin J, Koppers, Anthony A. P, \& Miggins, Daniel P. (2020). Reshuffling the Columbia River Basalt chronology; Picture Gorge Basalt, the earliest and longest-erupting formation. Geology (Boulder), 48(4), 348-352.

https://doi.org/10.1130/G47122.1 
Camp, V. (2021, February 1). The Yellowstone hotspot-the source of heat that powers Yellowstone's vast volcanic system-has long been thought to have initiated about 17 million years ago. A growing volume of evidence, however, suggests that it has been around much longer. Lecture presented at Just how long has the Yellowstone Hotspot been around? in CA, San Diego State University, San Diego.

Camp, V.E., Ross, M.E., Hanson, W.E., 2003, Genesis of Flood Basalts and Basin and Range Volcanic Rocks from Steens Mountain to the Malheur River Gorge, Oregon, GSA Bulletin, January 2003; v. 115; no. 1; p. 105-128.

Camp, VE, and Hanan, B.B., 2008, A Plume Triggered Delamination Origin for the Columbia River Basalt Group, Geosphere, v. 4, no. 3, p. 480-495.

Coble, M.A., and Mahood, G.A., 2016, Geology of the High Rock caldera complex, northwest Nevada, and implications for intense rhyolitic volcanism associated with flood basalt magmatism and the initiation of the Snake River Plain-Yellowstone trend, Geosphere, vol. 12, no. 1, 58-113, doi: 10.1130/GES01162.1

Cruz, M., and Streck, M.J., 2017, Geologic Map of the Calamity Butte Quadrangle, Oregon, unpublished USGS EdMap project.

Cruz, M., 2018, Field Mapping Investigation and Geochemical Analysis of Volcanic Units within the Dinner Creek Tuff Eruptive Center, Malheur County, Eastern Oregon. Dissertations and Theses. Paper 3837.http://pdxscholar.library.pdx.edu/open_access_etds/383710.15760/etd.3468

Dickinson, W., 1979, Mesozoic Forearc Basin in Central Oregon, Geology, vol. 7, p. 166 170

Donnelly-Nolan, Julie M, Champion, Duane E, Miller, C. Dan, Grove, Timothy L, \& Trimble, Deborah A. (1990). Post-11,000-year volcanism at Medicine Lake Volcano, Cascade Range, northern California. Journal of Geophysical Research: Solid Earth, 95(B12),19693-19704. https://doi.org/10.1029/JB095iB12p19693

Dorsey, R.J., and LaMaskin, T.A., 2007, Stratigraphic record of Triassic-Jurassic collisional tectonics in the Blue Mountains Province, Northeastern Oregon: American Journal of Science, v. 307, p. 1167-1193. 41

Dorsey, R.J., and LaMaskin, T.A., 2008, Mesozoic collision and accretion of oceanic terranes in the Blue Mountains province of north-eastern Oregon: new insights from the stratigraphic record. In Spencer, J. E., and Titley, S. R., eds. 'Circum-Pacific Tectonics, Geologic Evolution, and Ore deposits'. Tucson, AZ, Arizona Geol. Soc. Dig. 22.

Dorsey, R. J., \& LaMaskin, T. A. (2007). Stratigraphic record of Triassic-Jurassic collisional tectonics in the Blue Mountains province, north-eastern Oregon. Retrieved November 18, 2020, from https://www-ajsonlineorg.proxy.lib.pdx.edu/content/307/10/1167.short

Dvorak, C.L. and Streck, M.J., 2018, Geologic Map of the Jump-Off Joe Mountain Quadrangle, Oregon, unpublished USGS EdMap project.

Dvorak, C.L. and Streck, M.J., 2019, Geologic Map of the Big Canyon Quadrangle, Oregon, unpublished USGS EdMap project.

Enlows, H.E., and Parker, D.J., 1972, Geochronology of the Clarno Igneous Activity in the Mitchell Quadrangle, Wheeler County, Oregon, Ore Bin, vol. 34, p. 104 - 110

Ferns, Mark L., Streck, M.J, McClaughry, J.D (2017) "Field-Trip Guide to Columbia River Flood Basalts, Associated Rhyolites, and Diverse Post-Plume Volcanism in Eastern 
Oregon.” Scientific Investigations Report, USGS Publications Warehouse, 9 Aug. 2017, pubs.er.usgs.gov/publication/sir20175022O.

Ford, M.T., Grunder, A.L., Duncan, R.A., 2013, Bimodal Volcanism of the High Lava Plains and Northwestern Basin and Range of Oregon: Distribution and Tectonic Implications of Age-Progressive Rhyolites, Geochemistry Geophysics Geosystems, vol. 14, no. 8, p. 2836 -2857, doi: 10.1002/ggge.20175

Greene, R.C., 1973, Petrology of the Welded Tuff of Devine Canyon, Southeastern Oregon: USGS Professional Paper, v. 797.

Haddock, G. (1967). The Dinner Creek welded ash-flow tuff of the Malheur Gorge area, Malheur County, Oregon. University of Oregon.

Hanna, T. R. (2018). Areal Extent and Volumes of the Dinner Creek Tuff Units, Eastern Oregon Based on Lithology, Bulk Rock Composition and Feldspar Mineralogy (Order No. 10686814). Available from Dissertations \& Theses@ Portland State University;ProQuest Dissertations \& Theses Global. (2042936533).

http://stats.lib.pdx.edu/proxy.php?url=http://search.proquest.com.proxy.lib.pdx.ed $\mathrm{u} /$ dissertations-theses/areal-extent-volumes-dinner-creek-tuff units/docview/2042936533/se-2?accountid=13265

Henry, C.D., Castor, S.B., Starkel, W.A., Ellis, B.S., Wolff, J.A., Laravie, J.A., McIntosh, W.C., Heizler, M.T., 2017, Geology and Evolution of the McDermitt Caldera, Northern Nevada and Southeastern Oregon, Western USA, Geosphere, vol. 13, no. 4, p. 1066 - 1112, doi: 10.1130/GES01454.1

Isom, S.I. and Streck, M.J., 2016, Geologic Map of the Telephone Butte Quadrangle, Oregon, unpublished USGS EdMap project

Isom, S. L. (2017). Compositional and Physical Gradients in the Magmas of the Devine Canyon Tuff, Eastern Oregon: Constraints for Evolution Models of Voluminous High-silica Rhyolites (Order No. 10606618). Available from Dissertations \& Theses (a) PortlandState University; ProQuest Dissertations \& Theses Global; Publicly Available Content Database. (1964913942). http://stats.lib.pdx.edu/proxy.php?url=http://search.proquest.com.proxy.lib.pdx.ed $\mathrm{u} /$ dissertations-theses/compositional-physical-gradients-magmasdevine/docview/1964913942/se-2?accountid=13265

Jordan, B.T., Grunder, A.L., Duncan, R.A., Deino, A., 2004, Geochronology of Age Progressive Volcanism of the Oregon High Lava Plains: Implications for the Plume Interpretation of Yellowstone, Journal of Geophysics Research, vol. 109, B10202, doi: 10.1029/2003JB002776

Jordan, B.T., Grunder, A.L., Duncam, R.A., Deino, A.L., 2004. Geochronology of age progressive Volcanism of the Oregon High Lava Plains: Implications for the plume interpretation of Yellowstone: J Geophys. Res. 109, B10202, doi: 10.1029/2003JB002776.

LaMaskin, T.A., Vervoort, J.D., Dorsey, R.J., Wright, J.E., 2011, Early Mesozoic Paleogeography, and Tectonic Evolution of the Western United States: Insights from Detrital Zircon U-Pb Geochronology, Blue Mountains Province, Northeastern Oregon, Geological Society of America Bulletin, vol. 123, p. 1939 - 1965

Large, A. M. (2016). Silicic Volcanism at the Northern and Western Extent of the Columbia River Basalt Rhyolite Flare-up: Rhyolites of Buchanan Volcanic Complex and 
Dooley Mountain volcanic Complex, Oregon (Order No. 10158745). Available from Dissertations \& Theses @ Portland State University; ProQuest Dissertations \& Theses Global. (1839240247).

http://stats.lib.pdx.edu/proxy.php?url=http://search.proquest.com.proxy.lib.pdx.ed $\mathrm{u} /$ dissertations-theses/ silicic-volcanism-at-northern-westernextent/docview/1839240247/se-2?accountid=13265

Long, Maureen D, Gao, Haiying, Klaus, Amanda, Wagner, Lara S, Fouch, Matthew J, James, David E, \& Humphreys, Eugene. (2009). Shear wave splitting and the pattern of mantle flow beneath eastern Oregon. Earth and Planetary Science Letters, 288(3), 359-369. https://doi.org/10.1016/j.epsl.2009.09.039 Manchester, SR, 1981, Fossil Plants of the Eocene Clarno Nut Beds, Oregon Geology, vol. 43, p.75 - 81

McClaughry, J.D., Ferns, M.L., Streck, M.J., Patridge, K.A., Gordon, C.L., 2009, Paleogene Calderas of Central and Eastern Oregon: Eruptive Sources of Widespread Tuffs in the John Day and Clarno Formations, in 'Volcanoes to Vineyards: Geologic Field Trips Through the Dynamic Landscape of the Pacific Northwest.' Geological Society of America Field Guide, vol. 15, eds. J.E. O’Connor, R.J. Dorsey, and IP Madin, p. $407-434$

McKee, T.M., 1970, Preliminary Report on Fossil Fruits and Seeds from the Mammal Quarry of The Clarno Formation, Oregon, Ore Bin, vol. 32, p. 117 - 132 Milliard, Justin B. Two-stage Opening of the Northwestern Basin and Range in Eastern Oregon: Evidence from the Miocene Crane Basin. Oregon State U, 2010. Web.

Newberry volcano: Big Obsidian Flow. (n.d.). Retrieved May 1, 2021, from https://www.usgs.gov/volcanoes/newberry/big-obsidian-flow

Reidel, S.P., Camp, V.E., Tolan, T.L., Martin, B.S., 2013, The Columbia River Flood Basalt Province: Stratigraphy, Areal Extent, Volume, and Physical Volcanology, in 'The Columbia River Flood Basalt Province' eds S.P. Reidel, V.E. Camp, M.E. Ross, J.A. Wolff, BS. Martin, T.L. Tolan, and R.E. Wells, Geological Society of America Special Paper 497, p. 1 - 43

Retallack, G.J., Bestland, E.A., Fremd, T.J., 2000, Eocene and Oligocene Paleosols of Central Oregon, Geological Society of America Special Paper 344, 192 p.

Robinson, P.T., Brem, G.F., McKee, E.H., 1984, John Day Formation of Oregon: a Distal Record of Early Cascade Volcanism, Geology, vol. 12, p. 229 - 232, doi: 10.1130/00917613(1984)12<229:JDFOOA>2.0.CO;2

Robyn, T. L., 1977, Geology and petrology of the Strawberry Mountain volcanic series, Central Oregon. University of Oregon, Unpublished Ph.D. thesis, 189 p.

Robyn, T. L., 1979, Miocene volcanism in eastern Oregon-An example of calc-alkaline Volcanism unrelated to subduction. Journal of Volcanology and Geothermal Research, 5, 149-161.

Rogers, J.W., and Novitsky-Evans, J.M., 1977, The Clarno Formation of Central Oregon, USA, Volcanism on a Thin Continental Margin, Earth and Planetary Science Letters, vol. 34, p. 56 - 66, doi:10.1016/0012-821X(77)90105-4

Roche, Richard Louis, "Stratigraphic and geochemical evolution of the Glass Buttes complex, Oregon" (1987). Dissertations and Theses. Paper 3748. https://doi.org/10.15760/etd.5632

Rytuba, JJ, and Vander Meulen, DB, 1991, Hot-spring precious-metal systems in the Lake 
Owyhee volcanic field, Oregon-Idaho: in Raines, G.L., Lisle, R.E., Schafer, R.W., Wilkinson, W.H., eds., 'Geology and ore deposits of the Great Basin', Reno, Geological Society of Nevada, Symposium Proceedings, April 1 - 5, 1990, v. 2, p. $1085-1096$.

Rytuba, J.J., Vander Meulen, DB, Barlock, V.E., Ferns, M.L., 1991, Hot spring gold deposits in the Lake Owyhee volcanic field, eastern Oregon, field trip 10 of Buffa, R.H., Coyner, A.R.,eds., The geology and ore deposits of the Great Basin-Field trip guidebook compendium: Great Basin symposium on geology and ore deposits of the Great Basin, Reno, Nev., March 28-April 1, 1990, Reno, Nev., Geological Society of Nevada, p. 633-712.

Schwartz, J.J., Snoke, A.W., Frost, C.D., Barnes, C.G., Gromet, LP, 2010, Analysis of the Wallowa- Baker Terrane Boundary: Implications for Tectonic Accretion in the Blue Mountains Province, Northeastern Oregon, Geological Society of America Bulletin 122 , p. $517-53644$

Schwartz, J. J, Snoke, A. W, Cordey, F, Johnson, K, Frost, C. D, Barnes, C. G, LaMaskin, T. A, \& Wooden, J. L. (2011). Late Jurassic magmatism, metamorphism, and deformation in the Blue Mountains Province, northeast Oregon. Geological Society of America Bulletin, 123(9-10), 2083-2111. https://doi.org/10.1130/B30327.1

Sherrod, D. R., Mastin, L. G., Scott, W. E., \& Schilling, S. P. (1997). Volcano Hazards at Newberry Volcano, Oregon (Rep. No. 97-513). U.S. Department of the Interior U.S.G.S.

Steiner, A. R. (2016). Field Geology and Petrologic Investigation of the Strawberry Volcanics, Northeast Oregon (Order No. 10061476). Available from Dissertations \& Theses@ Portland State University; ProQuest Dissertations \& Theses Global. (1776488436).

http://stats.lib.pdx.edu/proxy.php?url=http://search.proquest.com.proxy.lib.pdx.ed $\mathrm{u} /$ dissertations-theses/ field-geology-petrologic-investigationstrawberry/docview/1776488436/se-

2?accountid=132652712.http://pdxscholar.library.pdx.edu/open_access_etds/2712 $10.15760 /$ etd. 2708

Steiner, Arron \& Streck, Martin. (2013). The Strawberry Volcanics: Generation of 'orogenic' andesites from tholeiite within an intra-continental volcanic suite centered on the Columbia River flood basalt province, USA. Geological Society, London, Special Publications. 385. 281-302. 10.1144/SP385.12.

Steiner, A., \& Streck, M. J. (2018). Voluminous and compositionally diverse, middle Miocene Strawberry Volcanics of NE Oregon: Magmatism cogenetic with flood basalts of the Columbia River Basalt Group. Field Volcanology: A Tribute to the Distinguished Career of Don Swanson: Geological Society of America Special Paper, 538, 41-62.

Streck, M.J., 2014, Evaluation of crystal mush extraction models to explain crystal-poor rhyolites: Journal of Volcanology and Geothermal Research, v. 284, p. 74-94.

Streck, M.J., and Grunder, A.L., 1995, Crystallization and welding variations in a widespread ignimbrite sheet; the Rattlesnake Tuff, eastern Oregon, USA: Bulletin of Volcanology, v. 57, p. 151-169, doi: 10.1007/BF00265035.

Streck, M.J., and Grunder, A.L., 1997, Compositional gradients and gaps in high-silica rhyolites of the Rattlesnake Tuff, Oregon: Journal of Petrology, v. 38, p. 133-163, 
doi: $10.1093 /$ petrology/38.1.133.

Streck, M.J., and Grunder, A.L., 1999, Enrichment of basalt and mixing of dacite in the rootzone of a large rhyolite chamber: Inclusions and pumices from the Rattlesnake Tuff, Oregon: Contributions to Mineralogy and Petrology, v. 136, p. 193-212, doi: $10.1007 / \mathrm{s} 004100050532$.

Streck, M.J, and Ferns, M.L., 2012, The Rhyolite flare-up of the Columbia River basalt province and its bearing on plume vs. non-plume models [abs.]: American Geophysical Union Abstract, no. DI53A-2372.

Streck, M.J., and Grunder, A.L., 2012, Temporal and crustal effects on differentiation of tholeiite to calc-alkaline and ferro-trachytic suites, High Lava Plains, Oregon, USA: American Geophysical Union Geochemistry, Geophysics, Geosystems, v. 13, no. 11, 24 p. [Also available at http://dx.doi.org/10.1029/2012GC004237.]

Streck, M., Ferns, M., \& McIntosh, W., 2015, Large, persistent rhyolitic magma reservoirs above Columbia River Basalt storage sites: The Dinner Creek Tuff Eruptive Center, eastern Oregon. Retrieved November 19, 2020, from https://pubs.geoscienceworld.org/gsa/geosphere/article/11/2/226/132195/Largepersistent-rhyolitic-magma-reservoirs-above

Stueber, D. O. (n.d.). Chapter 12: Glass Buttes, Oregon: 14,000 Years of Continuous Use. In 13915985851015764808 C. E. Skinner (Ed.), Toolstone Geography of the Pacific Northwest (2015 ed., pp. 193-207). Archaeology Press, Simon Fraser University.

Swanson, D.A., 1969, Reconnaissance Geologic Map of the East Half of the Bend Quadrangle, Crook, Wheeler, Jefferson, Wasco, and Deschutes Counties, Oregon, US Geological Survey Miscellaneous Investigations Map I-568, scale 1:250,000

Thayer, T.P., 1957, Some relations of later Tertiary volcanology and structure in eastern Oregon, v. 1 of Volcanology of the Cenozoic: 20th International Geological Congress, sec. 1, Mexico City, Mexico, 1956, sec. 1, p. 231-245.

Thayer, T.P., Brown, C.E., and Hay, R.I., 1967, Preliminary geologic map of the Prairie City quadrangle, Grant County, Oregon: US Geological Survey Open-File Map, scale $1: 62,500$.

Vallier, T.L., 1995, Petrology of Pre-Tertiary Igneous Rocks in the Blue Mountains Region of Oregon, Idaho, and Washington: Implications for the Geologic Evolution of a Complex Island Arc, in 'Geology of the Blue Mountains Region of Oregon, Idaho, and Washington: Petrology and Tectonic Evolution of Pre-Tertiary Blue Mountains Province, eds. T.L. Vallier and H.C. Brooks, USGS Professional Paper 1438, p. 125 209

Vallier, T. L., Brooks, Howard C., \& Geological Survey, issuing body. (1986). Geologic implications of Paleozoic and Mesozoic paleontology and biostratigraphy, Blue Mountains province, Oregon, and Idaho. United States Government Printing Office.

Wacaster, S., Streck, M.J., Belkin, H.H., and Bodnar, R.J., 2011, Compositional zoning of the Devine Canyon tuff, Oregon [abs.]: American Geophysical Union Abstract, no. V21C-2517.

Walker, G. W., \& Nolf, B. (2006). USGS: Geological Survey circular 838 (HIGH LAVA plains, brothers fault zone To Harney Basin, Oregon). Retrieved May 2021, from https://www.nps.gov/parkhistory/online_books/geology/publications/circ/838/sec 5.htm 
Walker G. W., 1979, Revisions to the Cenozoic stratigraphy of Harney basin, southeastern Oregon, USGS Bulletin 1475, 35 p.45

Ware, B.D., 2013, Age, Provenance, and Structure of the Weathersby Formation, Eastern Izee Sub-basin, Blue Mountains Province, Oregon and Idaho, Boise State University, MS thesis, $265 \mathrm{p}$.

Watkins, N.D., and Baksi, AK, 1974, Magnetostratigraphy and oroclinal folding of the Columbia River, Steens, and Owyhee basalts, Oregon, Washington, and Idaho: American Journal of

Science, v. 274, no. 2, p. 148-189. DOI: https://doi.org/10.2475/ajs.274.2.148

Whalen, J. B, Currie, K. L, \& Chappel, B. W. (1987). A-type granites: geochemical characteristics, discrimination and petrogenesis. Contributions to Mineralogy and Petrology, 95(4), 407-419. https://doi.org/10.1007/BF00402202

Weaver, B., Tarney, J. Empirical approach to estimating the composition of the continental crust. Nature 310, 575-577 (1984). https://doiorg.proxy.lib.pdx.edu/10.1038/310575a0

Wolff, J.A., Ramos, F.C., Hart, G.I., Patterson, J.D., Brandon, A.D., 2008, Columbia River Flood Basalts from a Centralized Crustal Magmatic System, Nature Geoscience, vol. 1, p. $177-180$

Wolff, J.A., and Ramos, F.C., 2013, Source materials for the main phase of the Columbia River Basalt Group: Geochemical evidence and implications for magma storage and transport, in Reidel, S.P.,Wood, JD, 1976, The Geology of the Castle Rock Area, Grant, Harney, and Malheur Counties, Oregon, Portland State University, MS thesis, $89 \mathrm{p}$.

Webb, B. M. (2017). The Littlefield Rhyolite, Eastern Oregon: Distinct Flow Units and Their Constraints on Age and Storage Sites of Grande Ronde Basalt Magmas (Order No. 10286664). Available from Dissertations \& Theses@ Portland State University; ProQuest Dissertations \& Theses Global. (1951944191). http://stats.lib.pdx.edu/proxy.php?url=http://search.proquest.com.proxy.lib.pdx.ed $\mathrm{u} /$ dissertations-theses/littlefield-rhyolite-eastern-oregon-distinctflow/docview/1951944191/se-2?accountid=13265

Westby, E. G. (2014). The Geology and Petrology of Enigmatic Rhyolites at Graveyard and Gordon Buttes, Mount Hood Quadrangle, Oregon (Order No. 1571681). Available from Dissertations \& Theses @ Portland State University; ProQuest Dissertations \& Theses Global. (1648169512).

http:/ / stats.lib.pdx.edu/proxy.php?url=http:// search.proquest.com.proxy.lib.pdx.ed $\mathrm{u} /$ dissertations-theses/geology-petrology-enigmatic-rhyolites-

at $/$ docview $/ 1648169512 /$ se2? accountid=13265

Young, B. C. (2020). Testing the Correlation of Trace Element Characteristics with the Petrology and Temperature of Eruption of Mid-Miocene Rhyolites in Eastern Oregon (Order No. 27836528). Available from Dissertations \& Theses @ Portland State University; ProQuest Dissertations \& Theses Global. (2445560669). http://stats.lib.pdx.edu/proxy.php?url=http://search.proquest.com.proxy.lib.pdx.ed $\mathrm{u} /$ dissertations-theses/testing-correlation-trace-elementcharacteristics/docview/2445560669/se-2?accountid=13265 


\title{
APPENDIX A:
}

\author{
Whole Rock Geochemical Data
}

A spreadsheet of the Strawberry Rhyolite Units that have more than one geochemical sample and their averages calculated. Multiple geochemical spreadsheets with their respective unit names have been broken down to categorize the Strawberry Rhyolites. Along with multiple more spreadsheets of all the non-Strawberry Rhyolite units found in the study area. 
Strawberry Volcanic Rhyolite unit averages

*9 of the 12 units have more than one geochemical sample to generate an average.

\begin{tabular}{|c|c|c|c|c|c|c|}
\hline Unit Abbreviation & $\begin{array}{l}\text { Canyon } \\
\text { Creek } \\
\text { Rhyolite } \\
\text { Trcc }\end{array}$ & $\begin{array}{l}\text { Kent } \\
\text { Spring } \\
\text { Rhyolite } \\
\text { Trks }\end{array}$ & $\begin{array}{l}\text { Wolf } \\
\text { Mountain } \\
\text { Rhyolite } \\
\text { Trwm } \\
\end{array}$ & $\begin{array}{l}\text { Antelope } \\
\text { Creek } \\
\text { Rhyolite } \\
\text { Trac } \\
\end{array}$ & $\begin{array}{l}\text { Buckhorn } \\
\text { Spring } \\
\text { Rhyolite } \\
\text { Trbs }\end{array}$ & $\begin{array}{l}\text { Three Cabin } \\
\text { Spring } \\
\text { Rhyolite } \\
\text { Trtcs }\end{array}$ \\
\hline $\begin{array}{l}\text { Amount of Samples } \\
\text { in Average }\end{array}$ & 4 & 7 & 8 & 2 & 2 & 9 \\
\hline XRF & \multicolumn{4}{|c|}{ Normalized Major Elements (Weight \%): } & & \\
\hline $\mathrm{SiO2}$ & 76.52 & 76.82 & 73.22 & 77.02 & 74.01 & 77.36 \\
\hline TiO2 & 0.20 & 0.06 & 0.33 & 0.09 & 0.34 & 0.13 \\
\hline Al2O3 & 12.92 & 13.30 & 14.71 & 12.98 & 14.35 & 12.82 \\
\hline $\mathrm{FeO}^{*}$ & 1.15 & 0.82 & 2.27 & 0.91 & 1.83 & 0.92 \\
\hline MnO & 0.03 & 0.04 & 0.05 & 0.04 & 0.02 & 0.02 \\
\hline MgO & 0.13 & 0.04 & 0.24 & 0.07 & 0.16 & 0.09 \\
\hline $\mathrm{CaO}$ & 0.82 & 0.56 & 1.92 & 0.69 & 1.34 & 0.72 \\
\hline $\mathrm{Na2O}$ & 4.11 & 3.61 & 3.63 & 3.87 & 4.19 & 3.61 \\
\hline $\mathrm{K} 2 \mathrm{O}$ & 4.09 & 4.74 & 3.59 & 4.32 & 3.71 & 4.31 \\
\hline P2O5 & 0.03 & 0.01 & 0.06 & 0.01 & 0.04 & 0.02 \\
\hline *Pre Normalized Sum & 98.11 & 96.83 & 96.54 & 99.26 & 98.56 & 98.87 \\
\hline LOI \% & 1.64 & 3.04 & 3.03 & 0.27 & 1.08 & 0.58 \\
\hline \multicolumn{7}{|c|}{ Unnormalized Trace Elements (ppm): } \\
\hline $\mathbf{N i}$ & 2.52 & 2.74 & 3.45 & 2.87 & 1.97 & 2.24 \\
\hline $\mathrm{Cr}$ & 3.27 & 3.26 & 4.85 & 3.11 & 3.19 & 3.25 \\
\hline Sc & 5.49 & 4.89 & 6.34 & 3.49 & 6.42 & 3.83 \\
\hline $\mathbf{V}$ & 5.93 & 1.57 & 24.21 & 3.31 & 12.38 & 5.02 \\
\hline $\mathbf{B a}$ & 1205.55 & 648.14 & 1287.85 & 1271.39 & 1360.37 & 1435.20 \\
\hline $\mathbf{R b}$ & 91.39 & 109.27 & 80.55 & 101.38 & 79.57 & 111.61 \\
\hline $\mathrm{Sr}$ & 79.79 & 28.49 & 217.97 & 59.70 & 162.60 & 70.53 \\
\hline $\mathbf{Z r}$ & 212.55 & 74.53 & 201.49 & 93.92 & 272.52 & 118.71 \\
\hline $\mathbf{Y}$ & 38.84 & 41.10 & 25.03 & 31.17 & 28.98 & 22.83 \\
\hline $\mathrm{Nb}$ & 13.16 & 19.83 & 10.44 & 15.06 & 13.51 & 9.86 \\
\hline $\mathbf{G a}$ & 15.22 & 16.95 & 15.84 & 15.93 & 16.67 & 13.90 \\
\hline $\mathbf{C u}$ & 1.68 & 1.29 & 5.24 & 1.62 & 3.29 & 2.36 \\
\hline Zn & 37.19 & 37.10 & 49.53 & 33.19 & 55.12 & 25.12 \\
\hline $\mathbf{P b}$ & 14.47 & 15.84 & 13.96 & 14.94 & 14.18 & 16.63 \\
\hline La & 30.79 & 22.22 & 23.28 & 32.64 & 33.83 & 26.66 \\
\hline $\mathrm{Ce}$ & 61.50 & 45.60 & 45.33 & 65.82 & 52.39 & 49.06 \\
\hline Th & 8.24 & 10.23 & 7.02 & 10.23 & 6.52 & 9.62 \\
\hline Nd & 27.45 & 21.58 & 20.26 & 27.14 & 28.51 & 19.47 \\
\hline $\mathbf{U}$ & 3.95 & 4.34 & 3.70 & 4.08 & 3.13 & 3.91 \\
\hline
\end{tabular}


Strawberry Volcanic Rhyolite Unit Averages

*9 of the 12 units have more than one geochemical sample to generate an average.

\begin{tabular}{|c|c|c|c|c|c|c|}
\hline Unit Abbreviation & $\begin{array}{l}\text { Canyon } \\
\text { Creek } \\
\text { Rhyolite } \\
\text { Trcc }\end{array}$ & $\begin{array}{l}\text { Kent } \\
\text { Spring } \\
\text { Rhyolite } \\
\text { Trks }\end{array}$ & $\begin{array}{l}\text { Wolf } \\
\text { Mountain } \\
\text { Rhyolite } \\
\text { Trwm }\end{array}$ & $\begin{array}{l}\text { Antelope } \\
\text { Creek } \\
\text { Rhyolite } \\
\text { Trac } \\
\end{array}$ & $\begin{array}{l}\text { Buckhorn } \\
\text { Spring } \\
\text { Rhyolite } \\
\text { Trbs } \\
\end{array}$ & $\begin{array}{l}\text { Three Cabin } \\
\text { Spring } \\
\text { Rhyolite } \\
\text { Trtcs }\end{array}$ \\
\hline \multicolumn{7}{|l|}{ ICP-MS } \\
\hline La ppm & 31.85 & 24.11 & 25.89 & 34.73 & 34.56 & 28.20 \\
\hline Ce ppm & 63.13 & 49.87 & 47.25 & 68.19 & 56.38 & 52.43 \\
\hline Pr ppm & 7.63 & 6.05 & 5.82 & 7.74 & 8.09 & 5.78 \\
\hline Nd ppm & 28.34 & 22.90 & 21.66 & 28.05 & 29.47 & 20.22 \\
\hline Sm ppm & 6.02 & 5.50 & 4.49 & 5.37 & 5.83 & 3.90 \\
\hline Eu ppm & 0.80 & 0.57 & 0.94 & 0.77 & 1.19 & 0.53 \\
\hline Gd ppm & 5.73 & 5.63 & 4.15 & 4.88 & 5.07 & 3.47 \\
\hline Tb ppm & 1.01 & 1.06 & 0.71 & 0.86 & 0.85 & 0.60 \\
\hline Dy ppm & 6.46 & 6.83 & 4.40 & 5.25 & 5.12 & 3.74 \\
\hline Ho ppm & 1.36 & 1.42 & 0.92 & 1.08 & 1.06 & 0.78 \\
\hline Er ppm & 3.95 & 4.05 & 2.65 & 3.08 & 2.91 & 2.24 \\
\hline Tm ppm & 0.62 & 0.63 & 0.42 & 0.49 & 0.46 & 0.35 \\
\hline Yb ppm & 4.01 & 4.11 & 2.76 & 3.26 & 3.02 & 2.32 \\
\hline Lu ppm & 0.64 & 0.65 & 0.44 & 0.51 & 0.46 & 0.37 \\
\hline Ba ppm & 1232.17 & 720.10 & 1306.88 & 1318.22 & 1396.44 & 1483.11 \\
\hline Th ppm & 8.41 & 10.60 & 7.38 & 10.77 & 7.23 & 10.10 \\
\hline Nb ppm & 13.02 & 19.88 & 10.33 & 14.94 & 13.38 & 8.77 \\
\hline Y ppm & 37.61 & 39.79 & 25.60 & 31.11 & 28.07 & 22.04 \\
\hline Hf ppm & 6.10 & 3.58 & 5.47 & 3.66 & 6.80 & 4.07 \\
\hline Ta ppm & 1.01 & 1.86 & 0.84 & 1.43 & 0.98 & 0.84 \\
\hline U ppm & 3.57 & 4.48 & 3.43 & 4.21 & 2.96 & 4.39 \\
\hline Pb ppm & 13.70 & 14.98 & 13.35 & 14.37 & 13.71 & 15.86 \\
\hline Rb ppm & 91.41 & 110.46 & 80.99 & 102.19 & 78.95 & 114.63 \\
\hline Cs ppm & 3.69 & 4.42 & 3.89 & 4.23 & 1.98 & 5.06 \\
\hline Sr ppm & 80.29 & 31.01 & 218.48 & 59.26 & 158.81 & 75.13 \\
\hline Sc ppm & 5.25 & 4.79 & 6.43 & 4.22 & 6.24 & 3.99 \\
\hline Zr ppm & 212.28 & 78.03 & 207.23 & 94.28 & 270.75 & 124.03 \\
\hline
\end{tabular}


Strawberry Volcanic Rhyolite unit averages

*9 of the 12 units have more than one geochemical sample to generate an average.

\begin{tabular}{|c|c|c|c|c|}
\hline $\begin{array}{l}\text { Unit Name } \\
\text { Unit Abbreviation }\end{array}$ & $\begin{array}{l}\text { Bridge Creek } \\
\text { Rhyolite } \\
\text { Trbc }\end{array}$ & $\begin{array}{l}\text { Elk Wallow } \\
\text { Spring Rhyolite } \\
\text { Trews }\end{array}$ & $\begin{array}{l}\text { Milk Spring Tuff } \\
\text { Ttms }\end{array}$ & \\
\hline $\begin{array}{l}\text { Amount of Samples } \\
\text { in Average }\end{array}$ & 3 & 2 & 2 & \\
\hline XRF & \multicolumn{4}{|c|}{ Normalized Major Elements (Weight \%): } \\
\hline $\mathrm{SiO2}$ & 73.39 & 76.30 & 59.60 & \\
\hline TiO2 & 0.29 & 0.10 & 1.16 & \\
\hline $\mathrm{Al2O3}$ & 14.20 & 13.67 & 16.42 & \\
\hline $\mathrm{FeO}^{*}$ & 2.23 & 1.15 & 8.29 & \\
\hline MnO & 0.05 & 0.04 & 0.14 & \\
\hline MgO & 0.47 & 0.10 & 4.22 & \\
\hline $\mathrm{CaO}$ & 2.17 & 0.77 & 6.26 & \\
\hline $\mathrm{Na2O}$ & 3.30 & 3.44 & 2.32 & \\
\hline K2O & 3.83 & 4.41 & 1.29 & \\
\hline P2O5 & 0.08 & 0.02 & 0.31 & \\
\hline *Pre Normalized Sum & 97.33 & 95.82 & 92.19 & \\
\hline \multirow[t]{2}{*}{ LOI \% } & 2.21 & 3.69 & 2.72 & \\
\hline & \multicolumn{4}{|c|}{ Unnormalized Trace Elements (ppm): } \\
\hline $\mathbf{N i}$ & 5.39 & 2.76 & 49.76 & \\
\hline $\mathrm{Cr}$ & 6.19 & 2.61 & 103.50 & \\
\hline $\mathrm{Sc}$ & 6.80 & 4.68 & 19.59 & \\
\hline $\mathbf{V}$ & 27.48 & 3.49 & 136.33 & \\
\hline $\mathrm{Ba}$ & 1183.04 & 1096.44 & 652.55 & \\
\hline $\mathbf{R b}$ & 89.00 & 88.48 & 23.21 & \\
\hline $\mathrm{Sr}$ & 196.34 & 59.58 & 396.28 & \\
\hline $\mathrm{Zr}$ & 151.59 & 119.46 & 149.12 & \\
\hline $\mathbf{Y}$ & 29.33 & 43.27 & 24.88 & \\
\hline Nb & 9.35 & 14.83 & 9.52 & \\
\hline Ga & 15.81 & 16.44 & 16.47 & \\
\hline $\mathrm{Cu}$ & 7.47 & 4.32 & 31.04 & \\
\hline $\mathrm{Zn}$ & 49.93 & 42.34 & 90.72 & \\
\hline $\mathbf{P b}$ & 14.14 & 14.78 & 5.88 & \\
\hline La & 26.81 & 32.68 & 19.93 & \\
\hline $\mathrm{Ce}$ & 43.78 & 55.58 & 40.62 & \\
\hline Th & 7.80 & 8.45 & 2.77 & \\
\hline Nd & 23.97 & 31.29 & 21.50 & \\
\hline $\mathbf{U}$ & 5.05 & 4.30 & 0.80 & 112 \\
\hline
\end{tabular}


Strawberry Volcanic Rhyolite unit averages

*9 of the 12 units have more than one geochemical sample to generate an average.

\begin{tabular}{|c|c|c|c|}
\hline $\begin{array}{l}\text { Unit Name } \\
\text { Unit Abbreviation }\end{array}$ & $\begin{array}{l}\text { Bridge Creek } \\
\text { Rhyolite } \\
\text { Trbc }\end{array}$ & $\begin{array}{l}\text { Elk Wallow } \\
\text { Spring Rhyolite } \\
\text { Trews }\end{array}$ & $\begin{array}{l}\text { Milk Spring Tuff } \\
\text { Ttms }\end{array}$ \\
\hline \multicolumn{4}{|l|}{ ICP-MS } \\
\hline La ppm & 26.50 & 33.20 & 19.76 \\
\hline Ce ppm & 44.82 & 57.48 & 40.79 \\
\hline Pr ppm & 6.34 & 8.18 & 5.20 \\
\hline Nd ppm & 24.24 & 31.56 & 21.10 \\
\hline Sm ppm & 5.26 & 6.73 & 4.62 \\
\hline Eu ppm & 0.98 & 0.82 & 1.37 \\
\hline Gd ppm & 4.86 & 6.52 & 4.53 \\
\hline Tb ppm & 0.82 & 1.15 & 0.73 \\
\hline Dy ppm & 5.11 & 7.08 & 4.32 \\
\hline Ho ppm & 1.05 & 1.47 & 0.89 \\
\hline Er ppm & 2.98 & 4.30 & 2.43 \\
\hline Tm ppm & 0.46 & 0.71 & 0.35 \\
\hline Yb ppm & 2.95 & 4.69 & 2.25 \\
\hline Lu ppm & 0.48 & 0.75 & 0.35 \\
\hline Ba ppm & 1216.88 & 1122.74 & 655.66 \\
\hline Th ppm & 8.38 & 9.29 & 2.39 \\
\hline Nb ppm & 9.13 & 14.96 & 9.67 \\
\hline Y ppm & 28.78 & 42.82 & 23.47 \\
\hline Hf ppm & 4.35 & 4.40 & 3.57 \\
\hline Ta ppm & 0.89 & 1.37 & 0.60 \\
\hline U ppm & 4.46 & 4.21 & 0.81 \\
\hline Pb ppm & 13.45 & 14.55 & 6.16 \\
\hline Rb ppm & 87.86 & 88.34 & 22.60 \\
\hline Cs ppm & 4.11 & 3.84 & 0.89 \\
\hline Sr ppm & 195.80 & 58.65 & 388.22 \\
\hline Sc ppm & 6.69 & 4.47 & 20.01 \\
\hline Zr ppm & 152.03 & 117.56 & 145.38 \\
\hline
\end{tabular}




\section{Rhyolite of Buckhorn Spring (Trbs)}

\begin{tabular}{|c|c|c|}
\hline Sample ID & BC19C30 & LVW-N-MS53 \\
\hline Quadrangle Unit & $\mathrm{BC}$ & LVW \\
\hline Abbreviation & Trbs & Trbs \\
\hline Latitude & 44.2446 & 44.24516 \\
\hline Longitude & -118.75257 & -118.72201 \\
\hline Thin Section Available & Yes & Yes \\
\hline \multicolumn{3}{|l|}{ Age Date } \\
\hline \multicolumn{3}{|c|}{ Normalized Major Elements (Weight \%): } \\
\hline $\mathrm{SiO} 2$ & 73.882 & 74.14 \\
\hline $\mathrm{TiO} 2$ & 0.337 & 0.34 \\
\hline Al2O3 & 14.558 & 14.14 \\
\hline $\mathrm{FeO}^{*}$ & 1.299 & 2.37 \\
\hline MnO & 0.011 & 0.03 \\
\hline MgO & 0.154 & 0.16 \\
\hline $\mathrm{CaO}$ & 1.537 & 1.15 \\
\hline $\mathrm{Na2O}$ & 4.458 & 3.93 \\
\hline $\mathrm{K2O}$ & 3.712 & 3.70 \\
\hline P2O5 & 0.051 & 0.04 \\
\hline *Pre Normalized Sum & 98.608 & 98.50 \\
\hline LOI \% & 1.077 & 1.07 \\
\hline \multicolumn{3}{|c|}{ Unnormalized Trace Elements (ppm): } \\
\hline $\mathbf{N i}$ & 2 & 2 \\
\hline $\mathrm{Cr}$ & 3 & 3 \\
\hline Sc & 6 & 7 \\
\hline $\mathbf{V}$ & 10 & 14 \\
\hline $\mathbf{B a}$ & 1408 & 1313 \\
\hline $\mathbf{R b}$ & 81 & 79 \\
\hline $\mathrm{Sr}$ & 183 & 142 \\
\hline $\mathrm{Zr}$ & 282 & 263 \\
\hline $\mathbf{Y}$ & 28 & 30 \\
\hline $\mathrm{Nb}$ & 13.1 & 14.0 \\
\hline $\mathbf{G a}$ & 17 & 17 \\
\hline $\mathrm{Cu}$ & 3 & 4 \\
\hline $\mathbf{Z n}$ & 60 & 50 \\
\hline $\mathbf{P b}$ & 14 & 14 \\
\hline La & 30 & 38 \\
\hline $\mathrm{Ce}$ & 51 & 54 \\
\hline Th & 6 & 7 \\
\hline Nd & 23 & 34 \\
\hline $\mathbf{U}$ & 3 & 3 \\
\hline
\end{tabular}


Rhyolite of Buckhorn Spring (Trbs)

ICP-MS

\begin{tabular}{|c|c|c|}
\hline Sample ID & ВC19C30 & LVW-N-MS53 \\
\hline La ppm & 30.84 & 38.28 \\
\hline Ce ppm & 55.95 & 56.81 \\
\hline Pr ppm & 6.93 & 9.25 \\
\hline Nd ppm & 25.16 & 33.78 \\
\hline Sm ppm & 5.27 & 6.39 \\
\hline Eu ppm & 1.21 & 1.17 \\
\hline Gd ppm & 4.80 & 5.33 \\
\hline Tb ppm & 0.81 & 0.89 \\
\hline Dy ppm & 5.03 & 5.20 \\
\hline Ho ppm & 1.06 & 1.06 \\
\hline Er ppm & 2.85 & 2.96 \\
\hline Tm ppm & 0.44 & 0.49 \\
\hline Yb ppm & 2.86 & 3.18 \\
\hline Lu ppm & 0.45 & 0.48 \\
\hline Ba ppm & 1452 & 1341 \\
\hline Th ppm & 7.18 & 7.28 \\
\hline Nb ppm & 12.87 & 13.90 \\
\hline Y ppm & 27.33 & 28.81 \\
\hline Hf ppm & 6.89 & 6.70 \\
\hline Ta ppm & 0.93 & 1.02 \\
\hline U ppm & 3.24 & 2.67 \\
\hline Pb ppm & 13.69 & 13.73 \\
\hline Rb ppm & 80.3 & 77.6 \\
\hline Cs ppm & 2.20 & 1.75 \\
\hline Sr ppm & 181 & 137 \\
\hline Sc ppm & 5.9 & 6.5 \\
\hline Zr ppm & 284 & 257 \\
\hline
\end{tabular}




\begin{tabular}{|c|c|c|}
\hline \multicolumn{3}{|c|}{ Rhyolite of Big Bend (Trbb) } \\
\hline Sample ID & LVW-N2-2 & \\
\hline Quadrangle Unit & LVW & \\
\hline Abbreviation & Trbb & \\
\hline Latitude & 44.1913706 & \\
\hline Longitude & -118.747144 & \\
\hline Thin Section Available & Yes & \\
\hline \multicolumn{3}{|l|}{ Age Date } \\
\hline Normal & Major Elements (Weight \%): & \\
\hline $\mathrm{SiO} 2$ & 70.41 & \\
\hline TiO2 & 0.52 & \\
\hline Al2O3 & 14.59 & \\
\hline $\mathrm{FeO}^{*}$ & 3.69 & \\
\hline MnO & 0.09 & \\
\hline MgO & 0.58 & \\
\hline $\mathrm{CaO}$ & 2.34 & \\
\hline $\mathrm{Na2O}$ & 3.94 & \\
\hline K2O & 3.71 & \\
\hline P2O5 & 0.13 & \\
\hline *Pre Normalized Sum & 98.43 & \\
\hline LOI \% & 1.17 & \\
\hline \multicolumn{3}{|c|}{ Unnormalized Trace Elements (ppm): } \\
\hline $\mathbf{N i}$ & 2 & \\
\hline $\mathrm{Cr}$ & 2 & \\
\hline Sc & 10 & \\
\hline $\mathbf{V}$ & 15 & \\
\hline Ba & 1215 & \\
\hline $\mathbf{R b}$ & 63 & \\
\hline $\mathrm{Sr}$ & 250 & \\
\hline $\mathbf{Z r}$ & 265 & \\
\hline $\mathbf{Y}$ & 41 & \\
\hline $\mathbf{N b}$ & 14.6 & \\
\hline Ga & 18 & \\
\hline $\mathrm{Cu}$ & 2 & \\
\hline $\mathbf{Z n}$ & 84 & \\
\hline $\mathbf{P b}$ & 11 & \\
\hline La & 35 & \\
\hline $\mathrm{Ce}$ & 61 & \\
\hline Th & 6 & \\
\hline Nd & 31 & 116 \\
\hline $\mathbf{U}$ & 2 & 116 \\
\hline
\end{tabular}


Rhyolite of Big Bend (Trbb)

\begin{tabular}{|c|c|}
\hline Sample ID & LVW-N2-2 \\
\hline La ppm & 33.72 \\
\hline Ce ppm & 62.67 \\
\hline Pr ppm & 8.40 \\
\hline Nd ppm & 32.73 \\
\hline Sm ppm & 6.68 \\
\hline Eu ppm & 1.39 \\
\hline Gd ppm & 6.53 \\
\hline Tb ppm & 1.08 \\
\hline Dy ppm & 6.45 \\
\hline Ho ppm & 1.39 \\
\hline Er ppm & 3.96 \\
\hline Tm ppm & 0.63 \\
\hline Yb ppm & 4.00 \\
\hline Lu ppm & 0.63 \\
\hline Ba ppm & 1237 \\
\hline Th ppm & 5.92 \\
\hline Nb ppm & 14.35 \\
\hline Y ppm & 39.86 \\
\hline Hf ppm & 6.62 \\
\hline Ta ppm & 0.97 \\
\hline U ppm & 2.28 \\
\hline Pb ppm & 11.66 \\
\hline Rb ppm & 62.1 \\
\hline Cs ppm & 2.01 \\
\hline Sr ppm & 238 \\
\hline Sc ppm & 9.0 \\
\hline Zr ppm & 260 \\
\hline
\end{tabular}




\section{Rhyolite of Bridge Creek (Trbc)}

\begin{tabular}{|c|c|c|c|}
\hline Sample ID & JJ-17-05 & JJ-17-8 & AS-SV-173 \\
\hline Quadrangle Unit & JOJM & JOJM & Just South Southwest of JOJM Trbc \\
\hline Abbreviation & Trbc & Trbc & Trbc \\
\hline Latitude & 44.0084 & 44.0162 & $44^{\circ} 3^{\prime} 46.80^{\prime \prime}$ \\
\hline Longitude & -118.8531 & -118.8537 & $118^{\circ} 51^{\prime} 51.80^{\prime \prime}$ \\
\hline Thin Section Available & Yes & & \\
\hline Age Date & & $14.39 \pm 0.03$ & $14.7 \pm 0.13$ \\
\hline XRF & \multicolumn{3}{|c|}{ Normalized Major Elements (Weight \%): } \\
\hline $\mathrm{SiO2}$ & 73.174 & 73.679 & 73.328 \\
\hline TiO2 & 0.304 & 0.298 & 0.270 \\
\hline $\mathrm{Al2O3}$ & 14.398 & 13.952 & 14.237 \\
\hline $\mathrm{FeO}^{*}$ & 2.380 & 2.288 & 2.015 \\
\hline MnO & 0.051 & 0.036 & 0.050 \\
\hline MgO & 0.467 & 0.359 & 0.570 \\
\hline $\mathrm{CaO}$ & 2.250 & 2.064 & 2.211 \\
\hline $\mathrm{Na2O}$ & 2.845 & 3.780 & 3.278 \\
\hline K2O & 4.057 & 3.466 & 3.964 \\
\hline P2O5 & 0.074 & 0.078 & 0.077 \\
\hline *Pre Normalized Sum & 95.883 & 98.781 & \\
\hline \multirow[t]{2}{*}{ LOI \% } & 3.642 & 0.780 & \\
\hline & \multicolumn{3}{|c|}{ Unnormalized Trace Elements (ppm): } \\
\hline $\mathbf{N i}$ & 6 & 6 & 4.5 \\
\hline $\mathrm{Cr}$ & 7 & 5 & 6.7 \\
\hline Sc & 7 & 7 & 6.5 \\
\hline $\mathbf{V}$ & 26 & 29 & 27.1 \\
\hline $\mathbf{B a}$ & 1163 & 1216 & 1169.9 \\
\hline $\mathbf{R b}$ & 85 & 90 & 92 \\
\hline $\mathrm{Sr}$ & 205 & 191 & 192.8 \\
\hline $\mathbf{Z r}$ & 152 & 165 & 137.7 \\
\hline $\mathbf{Y}$ & 29 & 33 & 25.6 \\
\hline $\mathbf{N b}$ & 9.4 & 10.2 & 8.5 \\
\hline Ga & 16 & 16 & 15.5 \\
\hline $\mathrm{Cu}$ & 8 & 8 & 6.4 \\
\hline $\mathbf{Z n}$ & 49 & 58 & 42.1 \\
\hline $\mathbf{P b}$ & 14 & 14 & 14.5 \\
\hline La & 26 & 29 & 24.8 \\
\hline $\mathrm{Ce}$ & 40 & 49 & 43.1 \\
\hline Th & 8 & 7 & 8.5 \\
\hline Nd & 25 & 28 & 18.8 \\
\hline $\mathbf{U}$ & 5 & 4 & 5.8 \\
\hline
\end{tabular}




\section{Rhyolite of Bridge Creek (Trbe)}

ICP-MS

\begin{tabular}{|c|c|c|c|}
\hline Sample ID & JJ-17-05 & JJ-17-8 & AS-SV-173 \\
\hline La ppm & 26.56 & 30.66 & 22.27 \\
\hline Ce ppm & 43.88 & 47.03 & 43.55 \\
\hline Pr ppm & 6.31 & 7.55 & 5.16 \\
\hline Nd ppm & 24.00 & 29.51 & 19.21 \\
\hline Sm ppm & 5.17 & 6.27 & 4.32 \\
\hline Eu ppm & 1.03 & 1.15 & 0.77 \\
\hline Gd ppm & 4.87 & 5.73 & 3.98 \\
\hline Tb ppm & 0.83 & 0.95 & 0.68 \\
\hline Dy ppm & 5.15 & 5.90 & 4.28 \\
\hline Ho ppm & 1.06 & 1.20 & 0.89 \\
\hline Er ppm & 2.97 & 3.40 & 2.55 \\
\hline Tm ppm & 0.45 & 0.52 & 0.39 \\
\hline Yb ppm & 2.78 & 3.44 & 2.61 \\
\hline Lu ppm & 0.48 & 0.56 & 0.42 \\
\hline Ba ppm & 1212 & 1247 & 1192 \\
\hline Th ppm & 7.97 & 8.43 & 8.74 \\
\hline Nb ppm & 9.32 & 9.79 & 8.28 \\
\hline Y ppm & 29.40 & 32.16 & 24.79 \\
\hline Hf ppm & 4.40 & 4.66 & 3.99 \\
\hline Ta ppm & 0.89 & 0.93 & 0.83 \\
\hline U ppm & 4.19 & 4.48 & 4.70 \\
\hline Pb ppm & 13.15 & 13.90 & 13.30 \\
\hline Rb ppm & 84.4 & 87.5 & 91.7 \\
\hline Cs ppm & 4.07 & 3.83 & 4.42 \\
\hline Sr ppm & 204 & 186 & 198 \\
\hline Sc ppm & 7.0 & 7.0 & 6.2 \\
\hline Zr ppm & 156 & 162 & 139 \\
\hline
\end{tabular}




\section{Rhyolite of Elk Wallow Spring (Trews)}

\begin{tabular}{lll} 
Sample ID & LVW-S-2 & RS20MPT2 \\
\hline Quadrangle Unit & LVW & MPT \\
Abbreviation & Trews & Trews \\
Latitude & 44.161448 & 44.077 \\
Longitude & -118.717 & -118.72106 \\
Thin Section Available & Yes & \\
Age Date & & \\
\hline
\end{tabular}

\begin{tabular}{lll}
\hline XRF & Normalized Major Elements (Weight \%): \\
\hline SiO2 & 75.78 & 76.82 \\
TiO2 & 0.10 & 0.11 \\
Al2O3 & 14.20 & 13.15 \\
FeO* & 1.26 & 1.04 \\
MnO & 0.04 & 0.04 \\
MgO & 0.08 & 0.13 \\
CaO & 0.71 & 0.84 \\
Na2O & 3.35 & 3.53 \\
K2O & 4.48 & 4.33 \\
P2O5 & 0.01 & 0.02 \\
*Pre Normalized Sum & 95.40 & 96.25 \\
LOI \% & 4.12 & 3.26 \\
\hline
\end{tabular}

Unnormalized Trace Elements (ppm):

\begin{tabular}{lll}
\hline $\mathbf{N i}$ & 3 & 3 \\
$\mathbf{C r}$ & 3 & 2 \\
$\mathbf{S c}$ & 6 & 4 \\
$\mathbf{V}$ & 4 & 2 \\
$\mathbf{B a}$ & 1039 & 1154 \\
$\mathbf{R b}$ & 81 & 96 \\
$\mathbf{S r}$ & 45 & 74 \\
$\mathbf{Z r}$ & 130 & 109 \\
$\mathbf{Y}$ & 56 & 31 \\
$\mathbf{N b}$ & 15.7 & 14.0 \\
$\mathbf{G a}$ & 18 & 15 \\
$\mathbf{C u}$ & 7 & 2 \\
$\mathbf{Z n}$ & 50 & 34 \\
$\mathbf{P b}$ & 16 & 14 \\
$\mathbf{L a}$ & 34 & 31 \\
$\mathbf{C e}$ & 52 & 59 \\
$\mathbf{T h}$ & 8 & 9 \\
$\mathbf{N d}$ & 36 & 26 \\
$\mathbf{U}$ & 4 & 4
\end{tabular}




\section{Rhyolite of Elk Wallow Spring (Trews)}

\begin{tabular}{|c|c|c|}
\hline Sample ID & LVW-S-2 & RS20MPT2 \\
\hline La ppm & 35.39 & 31.00 \\
\hline Ce ppm & 54.47 & 60.49 \\
\hline Pr ppm & 9.35 & 7.00 \\
\hline Nd ppm & 36.95 & 26.18 \\
\hline Sm ppm & 8.33 & 5.12 \\
\hline Eu ppm & 0.84 & 0.81 \\
\hline Gd ppm & 8.47 & 4.57 \\
\hline Tb ppm & 1.50 & 0.81 \\
\hline Dy ppm & 9.32 & 4.84 \\
\hline Ho ppm & 1.94 & 1.01 \\
\hline Er ppm & 5.68 & 2.92 \\
\hline Tm ppm & 0.93 & 0.49 \\
\hline Yb ppm & 6.19 & 3.19 \\
\hline Lu ppm & 0.97 & 0.52 \\
\hline Ba ppm & 1073 & 1173 \\
\hline Th ppm & 8.38 & 10.20 \\
\hline Nb ppm & 15.77 & 14.16 \\
\hline Y ppm & 55.27 & 30.36 \\
\hline Hf ppm & 5.00 & 3.81 \\
\hline Ta ppm & 1.41 & 1.33 \\
\hline U ppm & 4.02 & 4.40 \\
\hline Pb ppm & 15.33 & 13.77 \\
\hline Rb ppm & 81.0 & 95.6 \\
\hline Cs ppm & 3.29 & 4.39 \\
\hline Sr ppm & 45 & 72 \\
\hline Sc ppm & 5.3 & 3.7 \\
\hline Zr ppm & 128 & 107 \\
\hline
\end{tabular}


Rhyolite of Kent Spring (Trks)

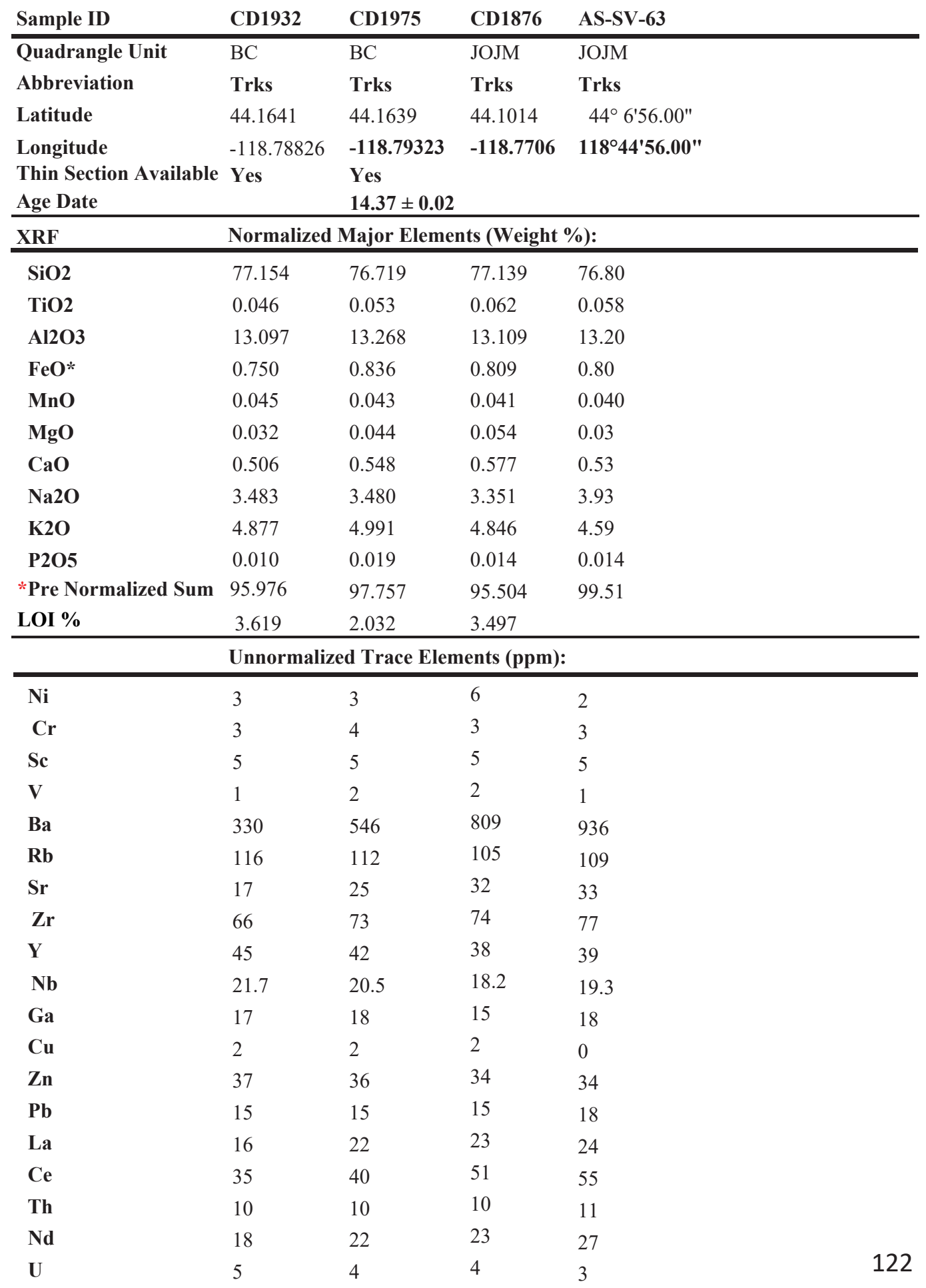




\section{Rhyolite of Kent Spring (Trks)}

\begin{tabular}{|c|c|c|c|}
\hline Sample ID & AS-SV-133 & AS-SV-134 & LVW-S-66 \\
\hline Quadrangle Unit & $\mathrm{BC}$ & $\mathrm{BC}$ & LVW \\
\hline Abbreviation & Trks & Trks & Trks \\
\hline Latitude & $44^{\circ} 10^{\prime} 7.60^{\prime \prime}$ & $44^{\circ} 10^{\prime} 4.40^{\prime \prime}$ & 44.12722894 \\
\hline $\begin{array}{l}\text { Longitude } \\
\text { Thin Section Available } \\
\text { Age Date }\end{array}$ & $118^{\circ} 47^{\prime} 35.30^{\prime \prime}$ & $118^{\circ} 47^{\prime} 33.40^{\prime \prime}$ & $\begin{array}{l}-118.7399601 \\
\text { Yes }\end{array}$ \\
\hline XRF & \multicolumn{3}{|c|}{ Normalized Major Elements (Weight \%): } \\
\hline $\mathrm{SiO2}$ & 76.88 & 76.82 & 76.23 \\
\hline TiO2 & 0.051 & 0.044 & 0.09 \\
\hline $\mathrm{Al2O3}$ & 13.35 & 13.23 & 13.83 \\
\hline $\mathrm{FeO}^{*}$ & 0.78 & 0.73 & 1.04 \\
\hline MnO & 0.044 & 0.044 & 0.05 \\
\hline MgO & 0.02 & 0.02 & 0.08 \\
\hline $\mathrm{CaO}$ & 0.52 & 0.52 & 0.69 \\
\hline $\mathrm{Na2O}$ & 3.52 & 3.86 & 3.63 \\
\hline K2O & 4.83 & 4.72 & 4.33 \\
\hline P2O5 & 0.011 & 0.012 & 0.02 \\
\hline *Pre Normalized Sum & 95.33 & 97.34 & 96.41 \\
\hline LOI \% & & & 3.01 \\
\hline
\end{tabular}

\begin{tabular}{llll}
\hline & \multicolumn{3}{c}{3.01} \\
\hline $\mathbf{N i}$ & \multicolumn{3}{c}{ Unnormalized Trace Elements (ppm): } \\
$\mathbf{C r}$ & 2 & 2 & 2 \\
$\mathbf{S c}$ & 3 & 4 & 3 \\
$\mathbf{V}$ & 5 & 6 & 4 \\
$\mathbf{B a}$ & 3 & 0 & 2 \\
$\mathbf{R b}$ & 330 & 359 & 1227 \\
$\mathbf{S r}$ & 114 & 114 & 95 \\
$\mathbf{Z r}$ & 17 & 18 & 58 \\
$\mathbf{Y}$ & 66 & 67 & 99 \\
$\mathbf{N b}$ & 47 & 46 & 31 \\
$\mathbf{G a}$ & 21.8 & 21.9 & 15.4 \\
$\mathbf{C u}$ & 17 & 18 & 17 \\
$\mathbf{Z n}$ & 0 & 1 & 2 \\
$\mathbf{P b}$ & 39 & 39 & 41 \\
$\mathbf{L a}$ & 17 & 17 & 15 \\
$\mathbf{C e}$ & 16 & 19 & 35 \\
$\mathbf{T h}$ & 35 & 33 & 71 \\
$\mathbf{N d}$ & 10 & 10 & 11 \\
$\mathbf{U}$ & 19 & 17 & 26
\end{tabular}




\section{Rhyolite of Kent Spring (Trks)}

\begin{tabular}{|c|c|c|c|c|c|c|}
\hline Sample ID & CD1932 & CD1975 & CD1876 & AS-SV-63 & AS-SV-133 AS-SV-134 & LVW-S-66 \\
\hline La ppm & 16.91 & 22.88 & 24.41 & 27.72 & 17.84 & 34.92 \\
\hline Ce ppm & 36.98 & 43.79 & 50.57 & 55.33 & 38.55 & 74.01 \\
\hline Pr ppm & 4.71 & 5.93 & 6.13 & 6.81 & 5.02 & 7.73 \\
\hline Nd ppm & 18.70 & 22.78 & 23.07 & 25.38 & 19.95 & 27.54 \\
\hline Sm ppm & 5.29 & 5.76 & 5.44 & 5.62 & 5.62 & 5.24 \\
\hline Eu ppm & 0.40 & 0.57 & 0.59 & 0.66 & 0.42 & 0.77 \\
\hline Gd ppm & 5.96 & 5.99 & 5.35 & 5.60 & 6.14 & 4.75 \\
\hline Tb ppm & 1.15 & 1.13 & 1.01 & 1.02 & 1.20 & 0.85 \\
\hline Dy ppm & 7.75 & 7.39 & 6.45 & 6.47 & 7.94 & 4.99 \\
\hline Ho ppm & 1.59 & 1.53 & 1.37 & 1.35 & 1.66 & 1.03 \\
\hline Er ppm & 4.57 & 4.30 & 3.87 & 3.84 & 4.74 & 2.99 \\
\hline Tm ppm & 0.72 & 0.66 & 0.61 & 0.58 & 0.73 & 0.49 \\
\hline Yb ppm & 4.67 & 4.31 & 3.97 & 3.70 & 4.74 & 3.27 \\
\hline Lu ppm & 0.73 & 0.68 & 0.64 & 0.60 & 0.74 & 0.51 \\
\hline Ba ppm & 341 & 565 & 823 & 969 & 349 & 1273 \\
\hline Th ppm & 10.19 & 10.65 & 10.19 & 10.80 & 10.44 & 11.34 \\
\hline Nb ppm & 21.81 & 20.87 & 18.11 & 19.27 & 23.39 & 15.82 \\
\hline Y ppm & 45.12 & 42.31 & 37.94 & 36.42 & 45.95 & 31.01 \\
\hline Hf ppm & 3.50 & 3.61 & 3.41 & 3.57 & 3.60 & 3.78 \\
\hline Ta ppm & 2.06 & 1.97 & 1.70 & 1.79 & 2.15 & 1.50 \\
\hline U ppm & 4.67 & 4.45 & 4.28 & 4.42 & 4.79 & 4.27 \\
\hline Pb ppm & 14.93 & 14.68 & 14.54 & 15.50 & 15.42 & 14.82 \\
\hline Rb ppm & 116.5 & 112.6 & 106.3 & 111.9 & 119.6 & 95.9 \\
\hline Cs ppm & 4.80 & 4.50 & 4.26 & 3.96 & 4.82 & 4.19 \\
\hline Sr ppm & 17 & 26 & 34 & 33 & 18 & 58 \\
\hline Sc ppm & 5.0 & 4.7 & 5.4 & 4.4 & 5.3 & 3.9 \\
\hline Zr ppm & 68 & 75 & 76 & 81 & 71 & 98 \\
\hline
\end{tabular}


Rhyolite of Kent Spring (Trks)

ICP-MS

\begin{tabular}{|c|c|c|c|}
\hline Sample ID & AS-SV-133 & AS-SV-134 & LVW-S-66 \\
\hline La ppm & 17.84 & & 34.92 \\
\hline Ce ppm & 38.55 & & 74.01 \\
\hline Pr ppm & 5.02 & & 7.73 \\
\hline Nd ppm & 19.95 & & 27.54 \\
\hline Sm ppm & 5.62 & & 5.24 \\
\hline Eu ppm & 0.42 & & 0.77 \\
\hline Gd ppm & 6.14 & & 4.75 \\
\hline Tb ppm & 1.20 & & 0.85 \\
\hline Dy ppm & 7.94 & & 4.99 \\
\hline Ho ppm & 1.66 & & 1.03 \\
\hline Er ppm & 4.74 & & 2.99 \\
\hline Tm ppm & 0.73 & & 0.49 \\
\hline Yb ppm & 4.74 & & 3.27 \\
\hline Lu ppm & 0.74 & & 0.51 \\
\hline Ba ppm & 349 & & 1273 \\
\hline Th ppm & 10.44 & & 11.34 \\
\hline Nb ppm & 23.39 & & 15.82 \\
\hline Y ppm & 45.95 & & 31.01 \\
\hline Hf ppm & 3.60 & & 3.78 \\
\hline Ta ppm & 2.15 & & 1.50 \\
\hline U ppm & 4.79 & & 4.27 \\
\hline Pb ppm & 15.42 & & 14.82 \\
\hline Rb ppm & 119.6 & & 95.9 \\
\hline Cs ppm & 4.82 & & 4.19 \\
\hline Sr ppm & 18 & & 58 \\
\hline Sc ppm & 5.3 & & 3.9 \\
\hline Zr ppm & 71 & & 98 \\
\hline
\end{tabular}




\section{Rhyolite of Antelope Creek (Trac)}

\begin{tabular}{lll} 
Sample ID & CD1879 & LVW-S-26 \\
\hline Quadrangle Unit & JOJM & LVW \\
Abbreviation & Trac & Trac \\
Latitude & 44.1136 & 44.1526307 \\
Longitude & -118.7781 & -118.724092 \\
Thin Section Available & Yes & Yes \\
Age Date & & \\
\hline XRF & Normalized Major Elements (Weight \%): \\
\hline SiO2 & 77.149 & 76.90 \\
TiO2 & 0.085 & 0.09 \\
Al2O3 & 13.015 & 12.95 \\
FeO* & 0.909 & 0.91 \\
MnO & 0.036 & 0.04 \\
MgO & 0.051 & 0.09 \\
CaO & 0.684 & 0.70 \\
Na2O & 3.742 & 3.99 \\
K2O & 4.318 & 4.32 \\
P2O5 & 0.010 & 0.02 \\
Pre Normalized Sum & 98.900 & 99.62 \\
LOI \% & 0.517 & 0.03 \\
\hline
\end{tabular}

Unnormalized Trace Elements (ppm):

\begin{tabular}{lll}
\hline $\mathbf{N i}$ & 4 & 2 \\
$\mathbf{C r}$ & 3 & 3 \\
$\mathbf{S c}$ & 3 & 4 \\
$\mathbf{V}$ & 4 & 2 \\
$\mathbf{B a}$ & 1254 & 1289 \\
$\mathbf{R b}$ & 102 & 101 \\
$\mathbf{S r}$ & 59 & 60 \\
$\mathbf{Z r}$ & 92 & 96 \\
$\mathbf{Y}$ & 31 & 31 \\
$\mathbf{N b}$ & 15.2 & 15.0 \\
$\mathbf{G a}$ & 16 & 16 \\
$\mathbf{C u}$ & 2 & 1 \\
$\mathbf{Z n}$ & 33 & 34 \\
$\mathbf{P b}$ & 15 & 15 \\
$\mathbf{L a}$ & 31 & 35 \\
$\mathbf{C e}$ & 64 & 68 \\
$\mathbf{T h}$ & 10 & 10 \\
$\mathbf{N d}$ & 26 & 28 \\
$\mathbf{U}$ & 4 & 4
\end{tabular}




\section{Rhyolite of Antelope Creek (Trac)}

\begin{tabular}{lll} 
ICP-MS & CD1879 & LVW-S-26 \\
\hline Sample ID & 34.72 & 34.74 \\
\hline La ppm & 68.12 & 68.25 \\
Ce ppm & 7.72 & 7.76 \\
Pr ppm & 27.93 & 28.16 \\
Nd ppm & 5.49 & 5.25 \\
Sm ppm & 0.80 & 0.74 \\
Eu ppm & 4.96 & 4.80 \\
Gd ppm & 0.88 & 0.83 \\
Tb ppm & 5.57 & 4.94 \\
Dy ppm & 1.12 & 1.03 \\
Ho ppm & 3.17 & 2.99 \\
Er ppm & 0.49 & 0.49 \\
Tm ppm & 3.28 & 3.24 \\
Yb ppm & 0.51 & 0.50 \\
Lu ppm & 1314 & 1322 \\
Ba ppm & 10.64 & 10.90 \\
Th ppm & 14.94 & 14.94 \\
Nb ppm & 30.90 & 31.33 \\
Y ppm & 3.69 & 3.63 \\
Hf ppm & 1.42 & 1.44 \\
Ta ppm & 4.21 & 4.22 \\
U ppm & 14.30 & 14.44 \\
Pb ppm & 104.4 & 100.0 \\
Rb ppm & 4.18 & 4.28 \\
Cs ppm & 60 & 59 \\
Sr ppm & 4.7 & 3.8 \\
Sc ppm & 95 & 94 \\
Zr ppm & & \\
\hline & & \\
\hline
\end{tabular}




\begin{tabular}{|c|c|c|c|c|c|}
\hline \multicolumn{6}{|c|}{ Rhyolite of Canyon Creek (Trce) } \\
\hline Sample ID & MS1904A & AS-SV-190 & LVW-N-25 & AS-SV-179 & \\
\hline Quadrangle Unit & $\mathrm{BC}$ & $\mathrm{BC}$ & LVW & $\mathrm{BC}$ & \\
\hline Abbreviation & Trec & Trec & Trec & Trtes & \\
\hline Latitude & 44.2501333 & $44^{\circ} 13^{\prime} 25.40^{\prime \prime}$ & 44.21937453 & $44^{\circ} 14^{\prime} 15.30^{\prime \prime}$ & \\
\hline Longitude & -118.8023 & $118^{\circ} 46^{\prime} 8.10^{\prime \prime}$ & -118.744795 & $118^{\circ} 46^{\prime} 43.10^{\prime \prime}$ & \\
\hline Thin Section Available & & & Yes & & \\
\hline Age Date & & $14.79 \pm 0.17$ & & $15.30 \pm 0.10$ & \\
\hline XRF & \multicolumn{5}{|c|}{ Normalized Major Elements (Weight \%): } \\
\hline $\mathrm{SiO2}$ & 73.842 & 76.926 & 76.84 & 78.454 & \\
\hline TiO2 & 0.286 & 0.188 & 0.20 & 0.145 & \\
\hline Al2O3 & 14.006 & 12.658 & 12.65 & 12.359 & \\
\hline $\mathrm{FeO}^{*}$ & 1.910 & 1.188 & 1.21 & 0.296 & \\
\hline MnO & 0.055 & 0.037 & 0.04 & 0.002 & \\
\hline MgO & 0.219 & 0.134 & 0.17 & 0.001 & \\
\hline $\mathrm{CaO}$ & 1.170 & 0.814 & 0.85 & 0.450 & \\
\hline $\mathrm{Na2O}$ & 4.216 & 4.121 & 4.12 & 3.991 & \\
\hline $\mathrm{K2O}$ & 4.254 & 3.912 & 3.91 & 4.285 & \\
\hline P2O5 & 0.041 & 0.023 & 0.03 & 0.016 & \\
\hline *Pre Normalized Sum & 96.466 & & 99.76 & & \\
\hline \multirow[t]{2}{*}{ LOI \% } & 3.288 & & 0.00 & & \\
\hline & \multicolumn{5}{|c|}{ Unnormalized Trace Elements (ppm): } \\
\hline $\mathbf{N i}$ & 2 & 3 & 1 & 3.4 & \\
\hline $\mathrm{Cr}$ & 3 & 3.2 & 3 & 3.4 & \\
\hline Sc & 6 & 5.1 & 5 & 5.6 & \\
\hline $\mathbf{v}$ & 9 & 5.2 & 7 & 2.7 & \\
\hline $\mathrm{Ba}$ & 1201 & 1222.6 & 1229 & 1169.7 & \\
\hline $\mathbf{R b}$ & 87 & 89.2 & 91 & 98 & \\
\hline $\mathrm{Sr}$ & 124 & 73.4 & 80 & 41.4 & \\
\hline $\mathrm{Zr}$ & 281 & 171 & 183 & 216 & \\
\hline $\mathbf{Y}$ & 35 & 37.6 & 37 & 45.8 & \\
\hline Nb & 13.9 & 12.6 & 12.7 & 13.4 & \\
\hline Ga & 16 & 14.4 & 15 & 16 & \\
\hline $\mathrm{Cu}$ & 2 & 2.7 & 2 & 0.5 & \\
\hline $\mathbf{Z n}$ & 56 & 35.2 & 36 & 21.2 & \\
\hline $\mathbf{P b}$ & 14 & 13.7 & 14 & 16.2 & \\
\hline $\mathbf{L a}$ & 31 & 28.3 & 29 & 34.4 & \\
\hline $\mathrm{Ce}$ & 60 & 61.9 & 54 & 70.1 & \\
\hline Th & 8 & 8.4 & 8 & 8.8 & \\
\hline Nd & 27 & 26.3 & 24 & 32.1 & \\
\hline $\mathbf{U}$ & 4 & 4 & 3 & 4.6 & 128 \\
\hline
\end{tabular}




\section{Rhyolite of Canyon Creek (Trec)}

ICP-MS

\begin{tabular}{|c|c|c|c|c|}
\hline Sample ID & MS1904A & AS-SV-190 & LVW-N-25 & AS-SV-179 \\
\hline La ppm & 31.73 & 29.51 & 29.24 & 36.91 \\
\hline Ce ppm & 63.82 & 59.07 & 58.66 & 70.96 \\
\hline Pr ppm & 7.55 & 7.04 & 7.00 & 8.95 \\
\hline Nd ppm & 27.98 & 26.15 & 25.82 & 33.40 \\
\hline Sm ppm & 5.93 & 5.67 & 5.37 & 7.12 \\
\hline Eu ppm & 1.04 & 0.80 & 0.72 & 0.66 \\
\hline Gd ppm & 5.57 & 5.36 & 5.18 & 6.82 \\
\hline Tb ppm & 0.97 & 0.97 & 0.92 & 1.20 \\
\hline Dy ppm & 6.18 & 6.22 & 5.71 & 7.73 \\
\hline Ho ppm & 1.31 & 1.31 & 1.22 & 1.62 \\
\hline Er ppm & 3.73 & 3.88 & 3.61 & 4.57 \\
\hline Tm ppm & 0.57 & 0.60 & 0.60 & 0.69 \\
\hline Yb ppm & 3.84 & 3.96 & 3.91 & 4.34 \\
\hline Lu ppm & 0.61 & 0.63 & 0.64 & 0.69 \\
\hline Ba ppm & 1240 & 1255 & 1240 & 1195 \\
\hline Th ppm & 8.01 & 8.46 & 8.27 & 8.89 \\
\hline Nb ppm & 13.87 & 12.29 & 12.29 & 13.62 \\
\hline Y ppm & 34.91 & 35.96 & 35.69 & 43.88 \\
\hline Hf ppm & 7.35 & 5.38 & 5.31 & 6.37 \\
\hline Ta ppm & 1.00 & 1.01 & 1.02 & 1.02 \\
\hline U ppm & 3.44 & 3.42 & 3.37 & 4.04 \\
\hline Pb ppm & 14.15 & 13.10 & 13.24 & 14.31 \\
\hline Rb ppm & 85.9 & 90.5 & 88.9 & 100.4 \\
\hline Cs ppm & 3.87 & 3.32 & 3.31 & 4.27 \\
\hline Sr ppm & 122 & 77 & 77 & 45 \\
\hline Sc ppm & 6.2 & 5.1 & 4.4 & 5.3 \\
\hline Zr ppm & 280 & 171 & 179 & 220 \\
\hline
\end{tabular}




\section{Rhyolite of Three Cabin Spring (Trtes)}

\begin{tabular}{|c|c|c|c|c|c|c|}
\hline Sample ID & CD1922 & CD1905 & MS-14-23 & CD1845 & AS-SV-85 & AS-SV-61 \\
\hline $\begin{array}{l}\text { Quadrangle Unit } \\
\text { Abbreviation } \\
\text { Latitude } \\
\text { Longitude } \\
\text { Thin Section Available } \\
\text { Age Date }\end{array}$ & $\begin{array}{l}\text { BC } \\
\text { Trtes } \\
44.1332 \\
-118.79103 \\
\text { Yes }\end{array}$ & $\begin{array}{l}\mathrm{BC} \\
\text { Trtes } \\
44.1437 \\
-118.8362 \\
\text { Yes }\end{array}$ & \begin{tabular}{l}
\multicolumn{1}{c}{ BC } \\
Trtes \\
44.1734 \\
-118.7539
\end{tabular} & $\begin{array}{l}\text { JOJM } \\
\text { Trtes } \\
44.1036 \\
-118.8283\end{array}$ & $\begin{array}{l}\text { BC } \\
\text { Trtes } \\
44^{\circ} 10^{\prime} 23.80^{\prime \prime} \\
118^{\circ} 44^{\prime} 14.20^{\prime \prime}\end{array}$ & $\begin{array}{l}\text { MPT } \\
\text { Trtes } \\
44^{\circ} 9^{\prime} 2.00^{\prime \prime} \\
118^{\circ} 44^{\prime} 28.00^{\prime \prime}\end{array}$ \\
\hline XRF & \multicolumn{6}{|c|}{ Normalized Major Elements (Weight \%): } \\
\hline $\mathrm{SiO} 2$ & 77.768 & 76.021 & 77.588 & 77.287 & 77.36 & 77.11 \\
\hline TiO2 & 0.106 & 0.185 & 0.117 & 0.148 & 0.130 & 0.088 \\
\hline $\mathrm{Al2O3}$ & 12.377 & 13.815 & 12.483 & 12.694 & 12.76 & 13.38 \\
\hline $\mathrm{FeO}^{*}$ & 0.854 & 0.774 & 0.914 & 1.036 & 1.39 & 0.95 \\
\hline $\mathrm{MnO}$ & 0.031 & 0.008 & 0.031 & 0.034 & 0.020 & 0.023 \\
\hline MgO & 0.089 & 0.143 & 0.109 & 0.145 & 0.06 & 0.05 \\
\hline $\mathrm{CaO}$ & 0.677 & 0.924 & 0.705 & 0.917 & 0.63 & 0.51 \\
\hline $\mathrm{Na2O}$ & 3.732 & 3.964 & 3.698 & 3.558 & 3.29 & 3.50 \\
\hline $\mathrm{K} 2 \mathrm{O}$ & 4.353 & 4.147 & 4.338 & 4.159 & 4.34 & 4.38 \\
\hline P2O5 & 0.013 & 0.019 & 0.017 & 0.021 & 0.020 & 0.017 \\
\hline *Pre Normalized Sum & 99.154 & 98.414 & 99.189 & 99.143 & 98.79 & 98.05 \\
\hline LOI \% & 0.310 & 1.240 & & 0.195 & & \\
\hline
\end{tabular}

\begin{tabular}{lllllll}
\hline \multicolumn{7}{c}{ Unnormalized Trace Elements (ppm): } \\
\hline $\mathbf{N i}$ & 3 & 2 & 0 & 3 & 3 & 3 \\
$\mathbf{C r}$ & 4 & 3 & 4 & 4 & 2 & 3 \\
$\mathbf{S c}$ & 4 & 5 & 3 & 4 & 4 & 4 \\
$\mathbf{V}$ & 4 & 9 & 4 & 6 & 8 & 3 \\
$\mathbf{B a}$ & 1383 & 1273 & 1500 & 1577 & 1587 & 1267 \\
$\mathbf{R b}$ & 116 & 101 & 113 & 114 & 114 & 99 \\
$\mathbf{S r}$ & 61 & 107 & 63 & 90 & 65 & 47 \\
$\mathbf{Z r}$ & 103 & 195 & 104 & 125 & 113 & 98 \\
$\mathbf{Y}$ & 23 & 21 & 24 & 22 & 20 & 27 \\
$\mathbf{N b}$ & 8.7 & 11.6 & 9.2 & 8.8 & 8.9 & 15.8 \\
$\mathbf{G a}$ & 14 & 16 & 13 & 13 & 13 & 15 \\
$\mathbf{C u}$ & 3 & 2 & 3 & 3 & 2 & 1 \\
$\mathbf{Z n}$ & 25 & 28 & 27 & 26 & 19 & 29 \\
$\mathbf{P b}$ & 16 & 16 & 17 & 16 & 18 & 16 \\
$\mathbf{L a}$ & 28 & 31 & 26 & 25 & 22 & 29 \\
$\mathbf{C e}$ & 50 & 56 & 50 & 45 & 41 & 57 \\
$\mathbf{T h}$ & 9 & 9 & 9 & 10 & 9 & 11 \\
$\mathbf{N d}$ & 20 & 20 & 20 & 17 & 17 & 22 \\
$\mathbf{U}$ & 4 & 4 & 3 & 4 & 4 & 4
\end{tabular}




\section{Rhyolite of Three Cabin Spring (Trtes)}

ICP-MS

\begin{tabular}{|c|c|c|c|c|c|c|}
\hline Sample ID & CD1922 & CD1905 & MS-14-23 & CD1845 & AS-SV-85 & AS-SV-61 \\
\hline La ppm & 27.62 & 30.65 & 27.48 & 25.50 & & \\
\hline Ce ppm & 52.17 & 58.77 & 51.27 & 47.96 & & \\
\hline Pr ppm & 5.73 & 5.91 & 5.72 & 5.30 & & \\
\hline Nd ppm & 20.24 & 20.13 & 19.73 & 18.70 & & \\
\hline Sm ppm & 3.97 & 3.85 & 3.90 & 3.71 & & \\
\hline Eu ppm & 0.47 & 0.72 & 0.50 & 0.53 & & \\
\hline Gd ppm & 3.54 & 3.37 & 3.55 & 3.35 & & \\
\hline Tb ppm & 0.60 & 0.59 & 0.62 & 0.61 & & \\
\hline Dy ppm & 3.87 & 3.70 & 3.82 & 3.73 & & \\
\hline Ho ppm & 0.81 & 0.76 & 0.81 & 0.76 & & \\
\hline Er ppm & 2.34 & 2.24 & 2.30 & 2.25 & & \\
\hline Tm ppm & 0.36 & 0.36 & 0.36 & 0.35 & & \\
\hline Yb ppm & 2.41 & 2.30 & 2.40 & 2.30 & & \\
\hline Lu ppm & 0.38 & 0.35 & 0.38 & 0.38 & & \\
\hline Ba ppm & 1431 & 1319 & 1550 & 1619 & & \\
\hline Th ppm & 10.36 & 9.74 & 10.12 & 9.70 & & \\
\hline Nb ppm & 8.78 & 11.85 & 6.14 & 8.38 & & \\
\hline Y ppm & 23.29 & 20.61 & 22.79 & 21.69 & & \\
\hline Hf ppm & 3.63 & 5.94 & 3.64 & 4.00 & & \\
\hline Ta ppm & 0.87 & 0.95 & 0.62 & 0.82 & & \\
\hline $\mathbf{U} \mathbf{p p m}$ & 4.55 & 4.05 & 4.35 & 4.32 & & \\
\hline Pb ppm & 15.91 & 15.45 & 15.77 & 15.39 & & \\
\hline Rb ppm & 116.5 & 100.8 & 114.4 & 117.6 & & \\
\hline Cs ppm & 5.46 & 3.24 & 5.02 & 5.48 & & \\
\hline Sr ppm & 62 & 106 & 66 & 89 & & \\
\hline Sc ppm & 3.4 & 5.0 & 3.4 & 4.5 & & \\
\hline Zr ppm & 103 & 195 & 107 & 129 & & \\
\hline
\end{tabular}




\section{Rhyolite of Three Cabin Spring (Trtes)}

\begin{tabular}{llll} 
Sample ID & AS-SV-60 & CD1830 & RS20MPT47 \\
\hline Quadrangle Unit & MPT & JOJM & MPT \\
Abbreviation & Trtes & Trtes & Trtcs \\
Latitude & $44^{\circ} 9^{\prime} 50.00^{\prime \prime}$ & 44.1187 & 44.07220651 \\
Longitude & $118^{\circ} 44^{\prime} 47.00^{\prime \prime}$ & -118.8224 & -118.7229364 \\
Thin Section Available & & Yes & \\
Age Date & & & \\
\hline XRF & Normalized Major Elements (Weight \%): \\
\hline SiO2 & 77.71 & 77.743 & 77.67 \\
TiO2 & 0.103 & 0.149 & 0.11 \\
A12O3 & 12.40 & 12.998 & 12.44 \\
FeO* & 0.85 & 0.654 & 0.90 \\
MnO & 0.030 & 0.008 & 0.03 \\
MgO & 0.08 & 0.058 & 0.10 \\
CaO & 0.68 & 0.789 & 0.69 \\
Na2O & 3.76 & 3.282 & 3.68 \\
K2O & 4.37 & 4.285 & 4.37 \\
P2O5 & 0.015 & 0.033 & 0.02 \\
*Pre Normalized Sum & 99.42 & 98.271 & 99.38 \\
LOI \% & & 0.966 & 0.17 \\
\hline & & & \\
\hline
\end{tabular}

\begin{tabular}{llll}
\hline & \multicolumn{3}{c}{ Unnormalized Trace Elements $(\mathbf{p p m}) \mathbf{~}$} \\
\hline $\mathbf{N i}$ & 1 & 3 & 2 \\
$\mathbf{C r}$ & 4 & 2 & 3 \\
$\mathbf{S c}$ & 4 & 3 & 3 \\
$\mathbf{V}$ & 2 & 5 & 4 \\
$\mathbf{B a}$ & 1408 & 1537 & 1384 \\
$\mathbf{R b}$ & 116 & 116 & 116 \\
$\mathbf{S r}$ & 59 & 81 & 61 \\
$\mathbf{Z r}$ & 99 & 124 & 107 \\
$\mathbf{Y}$ & 25 & 20 & 23 \\
$\mathbf{N b}$ & 8.6 & 8.7 & 8.5 \\
$\mathbf{G a}$ & 14 & 14 & 13 \\
$\mathbf{C u}$ & 1 & 2 & 4 \\
$\mathbf{Z n}$ & 25 & 22 & 26 \\
$\mathbf{P b}$ & 19 & 17 & 16 \\
$\mathbf{L a}$ & 23 & 30 & 27 \\
$\mathbf{C e}$ & 48 & 44 & 50 \\
$\mathbf{T h}$ & 10 & 9 & 10 \\
$\mathbf{N d}$ & 20 & 20 & 19 \\
$\mathbf{U}$ & 4 & 4 & 5
\end{tabular}




\section{Rhyolite of Three Cabin Spring (Trtes)}

ICP-MS

\begin{tabular}{llll}
\hline Sample ID & AS-SV-60 & CD1830 & RS20MPT47 \\
\hline La ppm & 28.82 & 29.52 & 27.79 \\
Ce ppm & 54.48 & 50.09 & 52.27 \\
Pr ppm & 6.04 & 5.97 & 5.78 \\
Nd ppm & 21.18 & 21.21 & 20.38 \\
Sm ppm & 4.10 & 4.03 & 3.76 \\
Eu ppm & 0.46 & 0.62 & 0.44 \\
Gd ppm & 3.64 & 3.44 & 3.40 \\
Tb ppm & 0.64 & 0.60 & 0.59 \\
Dy ppm & 3.98 & 3.52 & 3.57 \\
Ho ppm & 0.84 & 0.71 & 0.75 \\
Er ppm & 2.42 & 1.94 & 2.23 \\
Tm ppm & 0.37 & 0.30 & 0.36 \\
Yb ppm & 2.49 & 1.90 & 2.43 \\
Lu ppm & 0.41 & 0.29 & 0.39 \\
Ba ppm & 1445 & 1586 & 1431 \\
Th ppm & 10.50 & 9.90 & 10.38 \\
Nb ppm & 8.88 & 8.54 & 8.81 \\
Y ppm & 22.89 & 19.78 & 23.21 \\
Hf ppm & 3.66 & 4.03 & 3.61 \\
Ta ppm & 0.86 & 0.84 & 0.91 \\
U ppm & 4.58 & 4.39 & 4.49 \\
Pb ppm & 16.11 & 16.04 & 16.38 \\
Rb ppm & 117.1 & 120.1 & 115.8 \\
Cs ppm & 5.53 & 5.08 & 5.59 \\
Sr ppm & 58 & 83 & 62 \\
Sc ppm & 3.6 & 4.7 & 3.3 \\
Zr ppm & 102 & 127 & 106 \\
\hline & & & \\
& & & \\
\hline
\end{tabular}




\section{Rhyolite of Wolf Mountain (Trwm)}

\begin{tabular}{|c|c|c|c|c|}
\hline Sample ID & AS-SV-139 & AS-SV-144 & AS-SV-151 & CD1877 \\
\hline Quadrangle Unit & JOJM & JOJM & JOJM & JOJM \\
\hline Abbreviation & Trwm & Twmr & Trwm & Trwm \\
\hline Latitude & 44.0704 & 44.0786 & 44.0591 & 44.1190 \\
\hline Longitude & -118.7689 & -118.7536 & -118.7539 & -118.7834 \\
\hline Thin Section Available & & & & Yes \\
\hline Age Date & & $15.34 \pm 0.52$ & $16.16 \pm 0.17$ & \\
\hline XRF & \multicolumn{4}{|c|}{ Normalized Major Elements (Weight \%): } \\
\hline $\mathrm{SiO2}$ & 73.375 & 72.987 & 73.191 & 71.349 \\
\hline TiO2 & 0.362 & 0.352 & 0.350 & 0.367 \\
\hline $\mathrm{Al2O3}$ & 14.899 & 15.000 & 14.569 & 16.379 \\
\hline FeO* & 2.346 & 2.289 & 2.235 & 2.463 \\
\hline MnO & 0.034 & 0.037 & 0.053 & 0.039 \\
\hline MgO & 0.115 & 0.254 & 0.230 & 0.224 \\
\hline $\mathrm{CaO}$ & 1.658 & 2.027 & 1.993 & 2.496 \\
\hline $\mathrm{Na2O}$ & 3.719 & 3.530 & 3.861 & 3.092 \\
\hline K2O & 3.409 & 3.470 & 3.422 & 3.563 \\
\hline P2O5 & 0.082 & 0.054 & 0.097 & 0.029 \\
\hline *Pre Normalized Sum & 97.639 & 95.007 & 98.086 & 96.025 \\
\hline LOI \% & & & & 3.295 \\
\hline
\end{tabular}

\begin{tabular}{lllll}
\hline \multicolumn{5}{l}{ Unnormalized Trace Elements (ppm): } \\
\hline $\mathbf{N i}$ & 3 & 3 & 3 & 5 \\
$\mathbf{C r}$ & 5 & 5 & 5 & 6 \\
$\mathbf{S c}$ & 7 & 6 & 6 & 6 \\
$\mathbf{V}$ & 36 & 25 & 30 & 29 \\
$\mathbf{B a}$ & 1472 & 1358 & 1430 & 1311 \\
$\mathbf{R b}$ & 85 & 81 & 83 & 76 \\
$\mathbf{S r}$ & 202 & 253 & 223 & 299 \\
$\mathbf{Z r}$ & 175 & 164 & 167 & 163 \\
$\mathbf{Y}$ & 20 & 20 & 19 & 18 \\
$\mathbf{N b}$ & 10.1 & 9.2 & 9.4 & 9.0 \\
$\mathbf{G a}$ & 16 & 15 & 16 & 17 \\
$\mathbf{C u}$ & 8 & 3 & 7 & 7 \\
$\mathbf{Z n}$ & 48 & 43 & 49 & 43 \\
$\mathbf{P b}$ & 14 & 15 & 15 & 15 \\
$\mathbf{L a}$ & 30 & 24 & 25 & 0 \\
$\mathbf{C e}$ & 44 & 37 & 49 & 34 \\
$\mathbf{T h}$ & 8 & 7 & 8 & 7 \\
$\mathbf{N d}$ & 20 & 16 & 19 & 16 \\
$\mathbf{U}$ & 3 & 3 & 4 & 5 \\
& & & &
\end{tabular}




\section{Rhyolite of Wolf Mountain (Trwm)}

\begin{tabular}{|c|c|c|c|c|}
\hline Sample ID & CD1883 & CD1964 & MS-17-05 & RS20MPT49 \\
\hline Quadrangle Unit & JOJM & $\mathrm{BC}$ & JOJM & MPT \\
\hline Abbreviation & Trwm & Trwm & Trwm & Trwm \\
\hline Latitude & 44.1044 & 44.1378 & 44.0652 & 44.06324561 \\
\hline Longitude & -118.7952 & -118.79169 & -118.7926 & -118.7166629 \\
\hline $\begin{array}{l}\text { Thin Section Available } \\
\text { Age Date }\end{array}$ & Yes & Yes & $\sim 15.0$ & Yes \\
\hline XRF & \multicolumn{4}{|c|}{ Normalized Major Elements (Weight \%): } \\
\hline $\mathrm{SiO} 2$ & 72.620 & 72.773 & 75.451 & 73.98 \\
\hline TiO2 & 0.331 & 0.325 & 0.224 & 0.30 \\
\hline $\mathrm{Al2O3}$ & 14.783 & 14.980 & 13.324 & 13.71 \\
\hline $\mathrm{FeO}^{*}$ & 2.216 & 2.215 & 1.541 & 2.82 \\
\hline MnO & 0.054 & 0.061 & 0.046 & 0.08 \\
\hline MgO & 0.504 & 0.224 & 0.189 & 0.15 \\
\hline $\mathrm{CaO}$ & 2.464 & 2.322 & 1.019 & 1.35 \\
\hline $\mathrm{Na2O}$ & 3.622 & 3.406 & 3.656 & 4.17 \\
\hline K2O & 3.301 & 3.664 & 4.511 & 3.39 \\
\hline P2O5 & 0.103 & 0.030 & 0.037 & 0.05 \\
\hline *Pre Normalized Sum & 96.394 & 96.842 & 96.197 & 96.10 \\
\hline LOI \% & 2.646 & 2.613 & 3.251 & 3.34 \\
\hline \multicolumn{5}{|c|}{ Unnormalized Trace Elements (ppm): } \\
\hline $\mathbf{N i}$ & 4 & 3 & 5 & 2 \\
\hline $\mathrm{Cr}$ & 5 & 6 & 4 & 2 \\
\hline Sc & 5 & 5 & 6 & 10 \\
\hline $\mathbf{V}$ & 29 & 29 & 10 & 5 \\
\hline $\mathbf{B a}$ & 1335 & 1380 & 1176 & 842 \\
\hline $\mathbf{R b}$ & 81 & 83 & 101 & 55 \\
\hline $\mathrm{Sr}$ & 284 & 283 & 96 & 104 \\
\hline $\mathbf{Z r}$ & 147 & 151 & 192 & 454 \\
\hline $\mathbf{Y}$ & 19 & 17 & 36 & 53 \\
\hline $\mathbf{N b}$ & 7.4 & 7.5 & 11.3 & 19.6 \\
\hline $\mathbf{G a}$ & 16 & 16 & 15 & 17 \\
\hline $\mathrm{Cu}$ & 6 & 7 & 2 & 3 \\
\hline $\mathrm{Zn}$ & 45 & 43 & 45 & 81 \\
\hline $\mathbf{P b}$ & 15 & 14 & 14 & 11 \\
\hline La & 23 & 24 & 33 & 28 \\
\hline $\mathrm{Ce}$ & 47 & 38 & 57 & 56 \\
\hline Th & 6 & 7 & 9 & 5 \\
\hline Nd & 18 & 16 & 27 & 31 \\
\hline $\mathbf{U}$ & 3 & 4 & 5 & 3 \\
\hline
\end{tabular}




\section{Rhyolite of Wolf Mountain (Trwm)}

\begin{tabular}{|c|c|c|c|c|}
\hline Sample ID & AS-SV-139 & AS-SV-144 & AS-SV-151 & CD1877 \\
\hline La ppm & & 24.86 & 25.41 & 22.94 \\
\hline Ce ppm & & 43.51 & 46.23 & 39.35 \\
\hline Pr ppm & & 5.14 & 5.36 & 4.89 \\
\hline Nd ppm & & 18.81 & 19.62 & 17.32 \\
\hline Sm ppm & & 3.69 & 3.82 & 3.35 \\
\hline Eu ppm & & 0.77 & 0.88 & 0.87 \\
\hline Gd ppm & & 3.24 & 3.35 & 2.87 \\
\hline Tb ppm & & 0.54 & 0.54 & 0.49 \\
\hline Dy ppm & & 3.33 & 3.26 & 3.07 \\
\hline Ho ppm & & 0.68 & 0.67 & 0.62 \\
\hline Er ppm & & 1.95 & 1.88 & 1.77 \\
\hline Tm ppm & & 0.30 & 0.29 & 0.27 \\
\hline Yb ppm & & 2.02 & 1.93 & 1.84 \\
\hline Lu ppm & & 0.33 & 0.32 & 0.29 \\
\hline Ba ppm & & 1450 & 1485 & 1330 \\
\hline Th ppm & & 7.35 & 7.70 & 7.74 \\
\hline Nb ppm & & 9.16 & 8.78 & 8.20 \\
\hline Y ppm & & 19.14 & 17.93 & 16.66 \\
\hline Hf ppm & & 4.59 & 4.59 & 4.42 \\
\hline Ta ppm & & 0.74 & 0.74 & 0.73 \\
\hline U ppm & & 3.42 & 3.67 & 3.17 \\
\hline Pb ppm & & 13.68 & 13.91 & 14.33 \\
\hline Rb ppm & & 84.2 & 86.7 & 75.3 \\
\hline Cs ppm & & 4.32 & 4.20 & 3.63 \\
\hline Sr ppm & & 258 & 231 & 284 \\
\hline Sc ppm & & 6.6 & 5.8 & 6.2 \\
\hline Zr ppm & & 172 & 171 & 163 \\
\hline
\end{tabular}




\section{Rhyolite of Wolf Mountain (Trwm)}

\begin{tabular}{|c|c|c|c|c|}
\hline Sample ID & CD1883 & CD1964 & MS-17-05 & RS20MPT49 \\
\hline La ppm & 22.65 & 22.98 & 34.22 & 28.18 \\
\hline Ce ppm & 42.25 & 41.78 & 59.54 & 58.08 \\
\hline Pr ppm & 4.87 & 4.89 & 7.88 & 7.68 \\
\hline Nd ppm & 17.62 & 17.45 & 29.31 & 31.53 \\
\hline Sm ppm & 3.63 & 3.46 & 6.15 & 7.34 \\
\hline Eu ppm & 0.78 & 0.81 & 0.76 & 1.72 \\
\hline Gd ppm & 3.16 & 2.95 & 5.71 & 7.79 \\
\hline Tb ppm & 0.53 & 0.49 & 0.99 & 1.36 \\
\hline Dy ppm & 3.27 & 3.10 & 6.25 & 8.51 \\
\hline Ho ppm & 0.68 & 0.63 & 1.33 & 1.86 \\
\hline Er ppm & 1.88 & 1.80 & 3.81 & 5.51 \\
\hline Tm ppm & 0.29 & 0.28 & 0.60 & 0.87 \\
\hline Yb ppm & 1.92 & 1.87 & 3.93 & 5.83 \\
\hline Lu ppm & 0.30 & 0.30 & 0.62 & 0.92 \\
\hline Ba ppm & 1367 & 1422 & 1229 & 865 \\
\hline Th ppm & 7.00 & 7.29 & 8.98 & 5.62 \\
\hline Nb ppm & 7.46 & 7.63 & 11.50 & 19.59 \\
\hline Y ppm & 18.34 & 17.47 & 36.55 & 53.10 \\
\hline Hf ppm & 3.98 & 4.12 & 5.66 & 10.96 \\
\hline Ta ppm & 0.67 & 0.68 & 0.95 & 1.39 \\
\hline U ppm & 3.34 & 3.61 & 4.02 & 2.77 \\
\hline Pb ppm & 13.16 & 13.41 & 14.30 & 10.67 \\
\hline Rb ppm & 82.5 & 83.6 & 100.0 & 54.6 \\
\hline Cs ppm & 4.25 & 4.05 & 4.62 & 2.15 \\
\hline Sr ppm & 278 & 279 & 96 & 102 \\
\hline Sc ppm & 5.7 & 5.5 & 5.1 & 10.2 \\
\hline Zr ppm & 147 & 152 & 197 & 450 \\
\hline
\end{tabular}




\section{Milk Spring Tuff (Ttms)}

Sample ID

Quadrangle Unit

LVW-N-MS46

MS-14-20

Abbreviation

LVW

Ttms

JOJM

Latitude

44.23675

Ttms

Longitude

$-118.72873$

44.0341

Thin Section Available

Yes

Age Date

\begin{tabular}{lcl}
\hline XRF & Normalized Major Elements (Weight \%): \\
\hline SiO2 & 56.61 & 62.597 \\
TiO2 & 1.36 & 0.954 \\
Al2O3 & 16.07 & 16.765 \\
FeO* & 9.04 & 7.543 \\
MnO & 0.16 & 0.122 \\
MgO & 5.23 & 3.215 \\
CaO & 7.27 & 5.245 \\
Na2O & 2.70 & 1.945 \\
K2O & 1.17 & 1.415 \\
P2O5 & 0.41 & 0.199 \\
*Pre Normalized Sum & 95.09 & 89.282 \\
LOI \% & 4.33 & 1.114 \\
\hline
\end{tabular}

\begin{tabular}{|c|c|c|}
\hline $\mathbf{N i}$ & 85 & 14 \\
\hline $\mathrm{Cr}$ & 164 & 43 \\
\hline Sc & 23 & 17 \\
\hline V & 181 & 91 \\
\hline $\mathbf{B a}$ & 535 & 770 \\
\hline $\mathbf{R b}$ & 23 & 23 \\
\hline $\mathrm{Sr}$ & 412 & 380 \\
\hline $\mathbf{Z r}$ & 141 & 157 \\
\hline $\mathbf{Y}$ & 25 & 24 \\
\hline $\mathbf{N b}$ & 10.6 & 8.5 \\
\hline Ga & 16 & 17 \\
\hline $\mathrm{Cu}$ & 46 & 16 \\
\hline $\mathbf{Z n}$ & 87 & 94 \\
\hline $\mathbf{P b}$ & 5 & 6 \\
\hline La & 21 & 19 \\
\hline $\mathrm{Ce}$ & 42 & 39 \\
\hline Th & 2 & 4 \\
\hline Nd & 22 & 21 \\
\hline $\mathbf{U}$ & 1 & 1 \\
\hline
\end{tabular}




\section{Milk Spring Tuff (Ttms)}

\begin{tabular}{|c|c|c|}
\hline Sample ID & LVW-N-MS46 & MS-14-20 \\
\hline La ppm & 19.34 & 20.17 \\
\hline Ce ppm & 41.33 & 40.25 \\
\hline Pr ppm & 5.31 & 5.09 \\
\hline Nd ppm & 21.90 & 20.30 \\
\hline Sm ppm & 4.78 & 4.46 \\
\hline Eu ppm & 1.48 & 1.26 \\
\hline Gd ppm & 4.74 & 4.31 \\
\hline Tb ppm & 0.77 & 0.69 \\
\hline Dy ppm & 4.38 & 4.25 \\
\hline Ho ppm & 0.90 & 0.88 \\
\hline Er ppm & 2.47 & 2.39 \\
\hline Tm ppm & 0.36 & 0.35 \\
\hline Yb ppm & 2.33 & 2.17 \\
\hline Lu ppm & 0.36 & 0.34 \\
\hline Ba ppm & 535 & 777 \\
\hline Th ppm & 1.87 & 2.91 \\
\hline Nb ppm & 10.67 & 8.67 \\
\hline Y ppm & 24.26 & 22.68 \\
\hline Hf ppm & 3.31 & 3.83 \\
\hline Ta ppm & 0.64 & 0.56 \\
\hline U ppm & 0.68 & 0.94 \\
\hline Pb ppm & 5.21 & 7.10 \\
\hline Rb ppm & 23.1 & 22.1 \\
\hline Cs ppm & 0.59 & 1.19 \\
\hline Sr ppm & 398 & 378 \\
\hline Sc ppm & 22.3 & 17.7 \\
\hline Zr ppm & 139 & 152 \\
\hline
\end{tabular}




\section{Milk Spring Tuff, Unit 1 (Ttms1)}

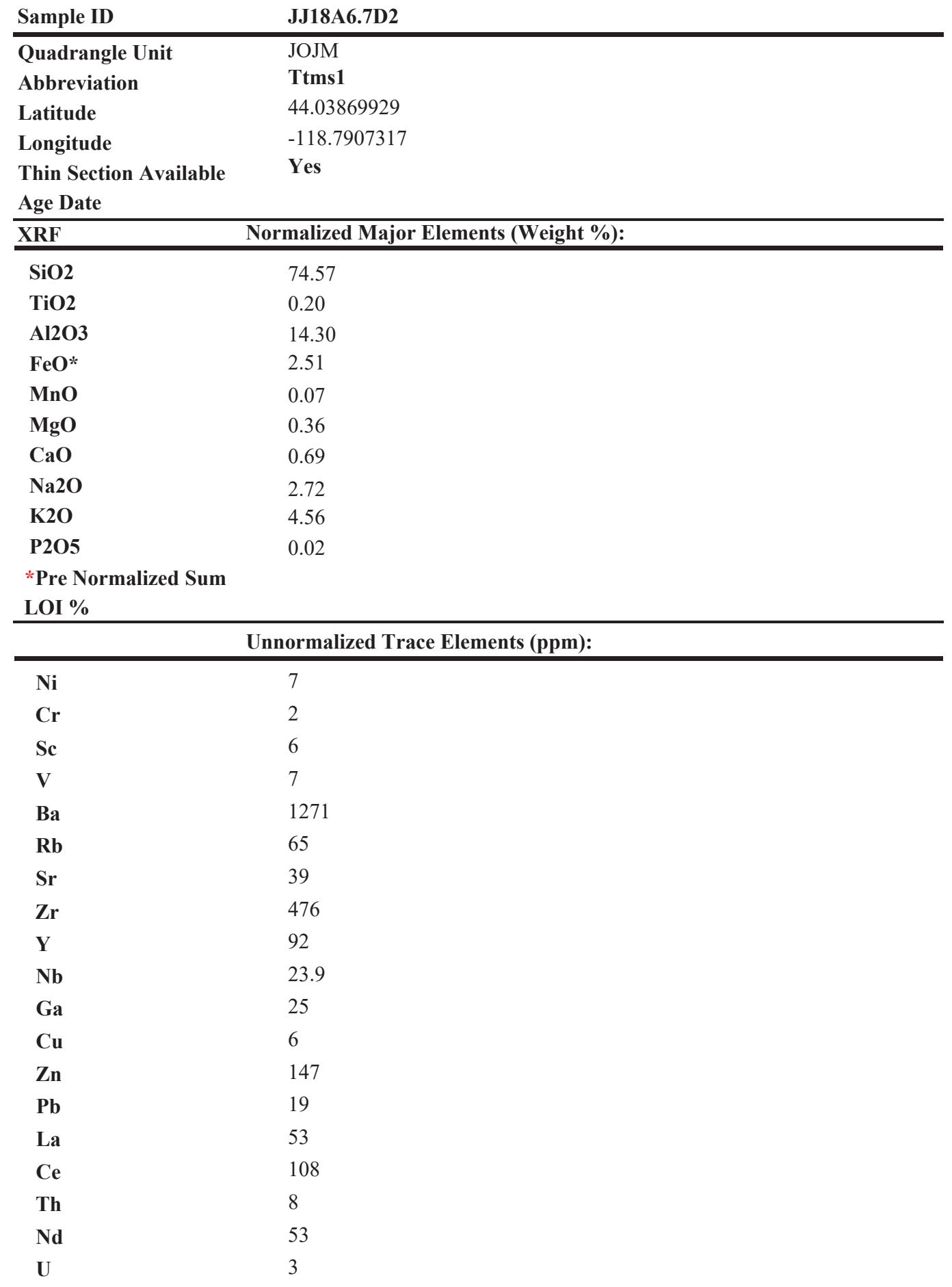




\section{Milk Spring Tuff, Unit 1 (Ttms1)}

\begin{tabular}{|c|c|}
\hline Sample ID & JJ18A6.7D2 \\
\hline La ppm & 54.81 \\
\hline Ce ppm & 113.69 \\
\hline Pr ppm & 14.13 \\
\hline Nd ppm & 55.57 \\
\hline Sm ppm & 12.68 \\
\hline Eu ppm & 2.19 \\
\hline Gd ppm & 13.14 \\
\hline Tb ppm & 2.45 \\
\hline Dy ppm & 16.29 \\
\hline Ho ppm & 3.50 \\
\hline Er ppm & 10.10 \\
\hline Tm ppm & 1.57 \\
\hline Yb ppm & 10.06 \\
\hline Lu ppm & 1.60 \\
\hline Ba ppm & 1298 \\
\hline Th ppm & 8.53 \\
\hline Nb ppm & 23.71 \\
\hline Y ppm & 93.08 \\
\hline Hf ppm & 12.80 \\
\hline Ta ppm & 1.57 \\
\hline U ppm & 3.08 \\
\hline Pb ppm & 18.80 \\
\hline Rb ppm & 68.8 \\
\hline Cs ppm & 2.46 \\
\hline Sr ppm & 40 \\
\hline Sc ppm & 5.3 \\
\hline Zr ppm & 483 \\
\hline
\end{tabular}




\section{*Unassigned Rhyolite Unit}

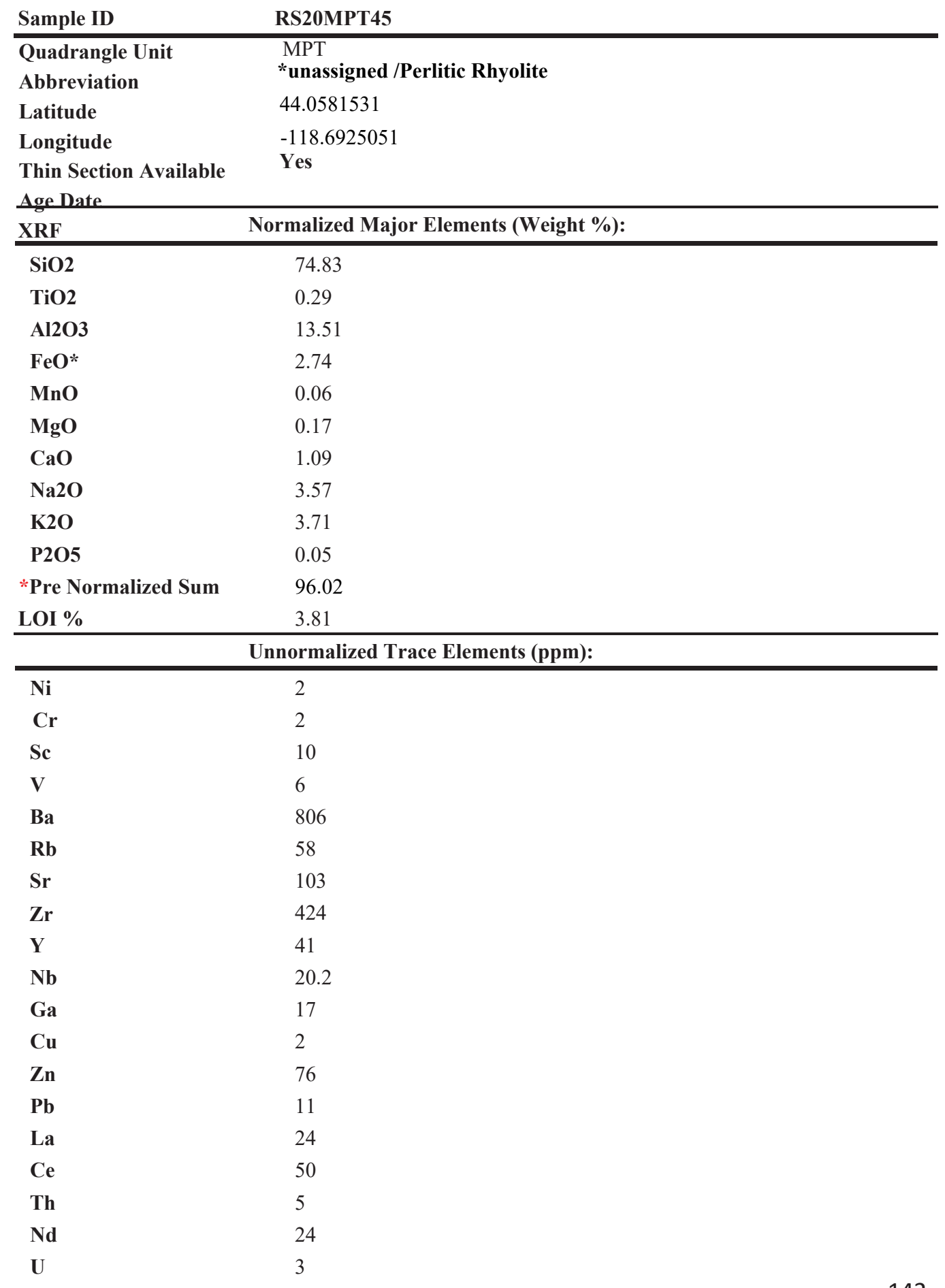




\section{*Unassigned Rhyolite Unit}

\begin{tabular}{ll} 
ICP-MS & RS20MPT45 \\
\hline Sample ID & 24.97 \\
\hline La ppm & 51.91 \\
Ce ppm & 6.51 \\
Pr ppm & 26.37 \\
Nd ppm & 5.84 \\
Sm ppm & 1.24 \\
Eu ppm & 5.94 \\
Gd ppm & 1.06 \\
Tb ppm & 6.43 \\
Dy ppm & 1.43 \\
Ho ppm & 4.25 \\
Er ppm & 0.69 \\
Tm ppm & 4.27 \\
Yb ppm & 0.75 \\
Lu ppm & 830 \\
Ba ppm & 5.83 \\
Th ppm & 19.74 \\
Nb ppm & 40.32 \\
Y ppm & 10.37 \\
Hf ppm & 1.39 \\
Ta ppm & 2.83 \\
U ppm & 10.90 \\
Pb ppm & 57.9 \\
Rb ppm & 2.19 \\
Cs ppm & 102 \\
Sr ppm & 9.6 \\
Sc ppm & 421 \\
Zr ppm & \\
\hline & \\
& \\
\hline
\end{tabular}


All other units that are not the Strawberry Rhyolites

\begin{tabular}{|c|c|c|c|c|c|}
\hline Sample ID & MS-18-02 & MS-18-05 & BC19B47 & MS-15-38 & \\
\hline Quadrangle Unit & JOJ & JOJ & $\mathrm{BC}$ & JOJ & \\
\hline Abbreviation & Thsd & Tmus & Tdit1 & Tdit1 & \\
\hline Latitude & 44.0132 & 44.0122 & 44.2029 & 44.0106 & \\
\hline Longitude & -118.7819 & -118.7907 & -118.8028 & -118.7819 & \\
\hline Thin Section Available & & & yes & & \\
\hline Age Date & \multicolumn{4}{|c|}{ Oligocene, $\sim 23 \mathrm{ma}$} & \\
\hline $\mathrm{SiO2}$ & 66.671 & 76.147 & 75.211 & 75.456 & \\
\hline TiO2 & 0.727 & 0.311 & 0.223 & 0.184 & \\
\hline $\mathrm{Al2O3}$ & 20.790 & 19.389 & 12.995 & 12.676 & \\
\hline $\mathrm{FeO}^{*}$ & 1.761 & 1.334 & 2.089 & 2.446 & \\
\hline $\mathrm{MnO}$ & 0.012 & 0.014 & 0.049 & 0.058 & \\
\hline MgO & 0.423 & 0.323 & 0.043 & 0.154 & \\
\hline $\mathrm{CaO}$ & 4.652 & 0.267 & 0.346 & 0.664 & \\
\hline $\mathrm{Na2O}$ & 3.705 & 0.408 & 3.322 & 2.497 & \\
\hline $\mathrm{K2O}$ & 1.088 & 1.793 & 5.709 & 5.851 & \\
\hline P2O5 & 0.170 & 0.015 & 0.013 & 0.015 & \\
\hline *Pre Normalized Sum & 94.740 & 90.775 & 95.566 & 94.645 & \\
\hline LOI \% & 4.688 & 8.502 & 3.911 & 4.086 & \\
\hline $\mathbf{N i}$ & 6.368 & 2.600 & 2.338 & 1.881 & \\
\hline $\mathrm{Cr}$ & 16.418 & 14.600 & 3.682 & 0.792 & \\
\hline Sc & 9.453 & 7.200 & 2.289 & 4.257 & \\
\hline $\mathbf{V}$ & 60.695 & 41.700 & 2.438 & 5.940 & \\
\hline $\mathbf{B a}$ & 1315.589 & 436.800 & 1803.338 & 1372.239 & \\
\hline $\mathbf{R b}$ & 7.118 & 97.020 & 79.755 & 90.684 & \\
\hline $\mathrm{Sr}$ & 593.717 & 35.600 & 45.024 & 35.343 & \\
\hline $\mathbf{Z r}$ & 152.414 & 113.643 & 407.244 & 448.700 & \\
\hline $\mathbf{Y}$ & 10.945 & 27.700 & 62.785 & 106.326 & \\
\hline $\mathbf{N b}$ & 9.552 & 22.100 & 24.278 & 24.354 & \\
\hline Ga & 20.895 & 20.800 & 21.641 & 21.087 & \\
\hline $\mathbf{C u}$ & 14.129 & 8.100 & 2.687 & 4.356 & \\
\hline Zn & 31.044 & 52.600 & 136.415 & 168.795 & \\
\hline $\mathbf{P b}$ & 17.512 & 13.200 & 15.124 & 18.117 & \\
\hline $\mathbf{L a}$ & 17.512 & 24.600 & 43.581 & 56.232 & \\
\hline $\mathrm{Ce}$ & 33.731 & 35.800 & 85.968 & 99.396 & \\
\hline Th & 3.582 & 10.200 & 6.070 & 6.831 & \\
\hline Nd & 14.428 & 17.000 & 44.377 & 59.499 & \\
\hline $\mathbf{U}$ & 2.388 & 3.200 & 4.080 & 4.059 & 144 \\
\hline
\end{tabular}


All other units that are not the Strawberry Rhyolites

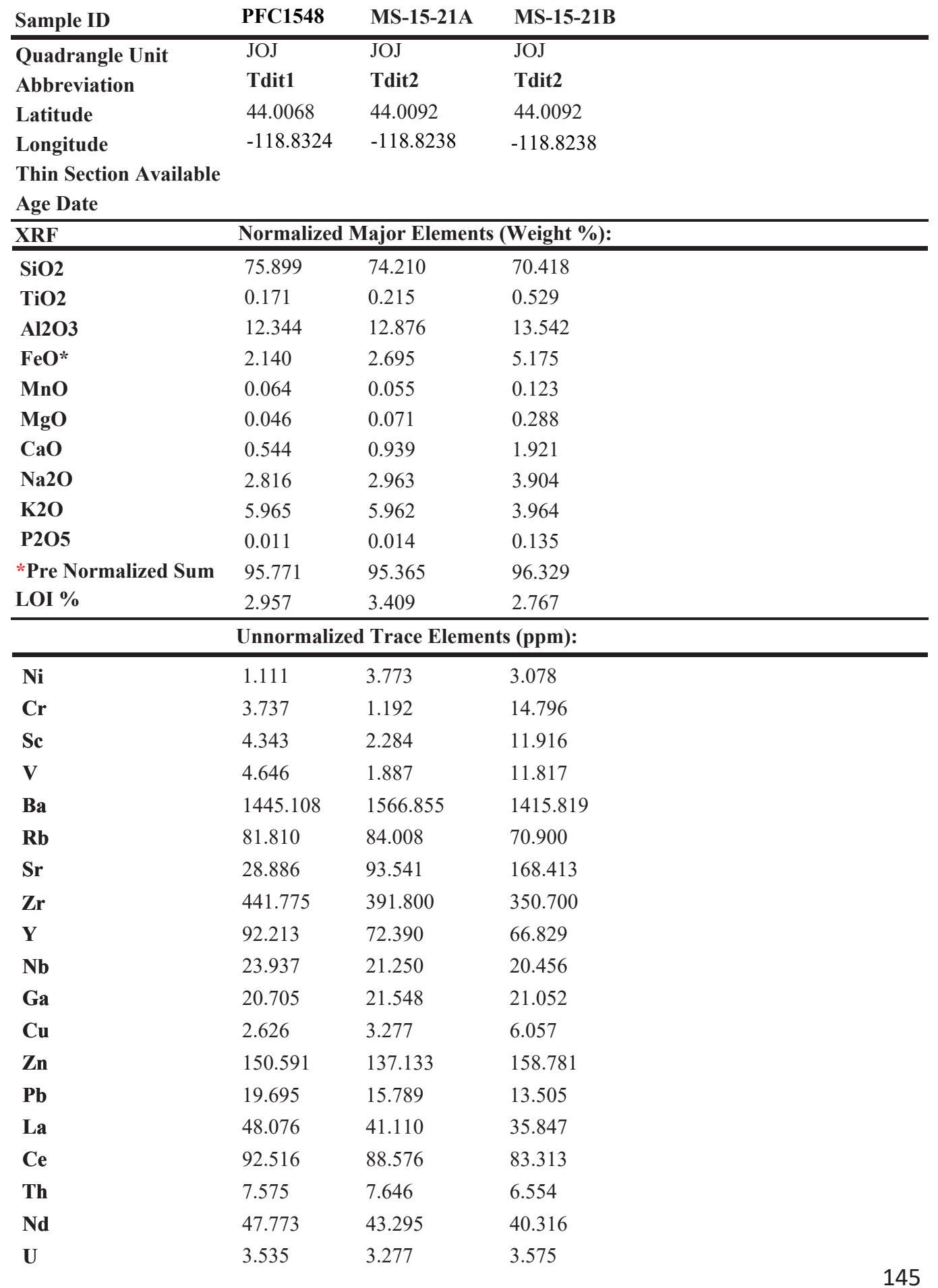




\section{All other units that are not the Strawberry Rhyolites}

ICP-MS

\begin{tabular}{|c|c|c|c|c|}
\hline Sample ID & MS-18-02 & MS-18-05 & BC19B47 & MS-15-38 \\
\hline La ppm & 19.984 & 23.561 & 43.916 & 61.463 \\
\hline Ce ppm & 37.279 & 37.446 & 89.236 & 102.689 \\
\hline Pr ppm & 4.397 & 5.346 & 11.720 & 15.690 \\
\hline Nd ppm & 15.799 & 19.215 & 46.436 & 62.515 \\
\hline Sm ppm & 3.054 & 4.065 & 10.589 & 14.401 \\
\hline Eu ppm & 1.201 & 0.585 & 1.988 & 2.160 \\
\hline Gd ppm & 2.504 & 3.850 & 10.080 & 15.225 \\
\hline Tb ppm & 0.403 & 0.696 & 1.794 & 2.761 \\
\hline Dy ppm & 2.286 & 4.483 & 11.648 & 18.597 \\
\hline Ho ppm & 0.438 & 0.912 & 2.444 & 4.038 \\
\hline Er ppm & 1.100 & 2.560 & 6.976 & 11.765 \\
\hline Tm ppm & 0.157 & 0.394 & 1.062 & 1.814 \\
\hline Yb ppm & 1.001 & 2.558 & 6.799 & 11.694 \\
\hline Lu ppm & 0.143 & 0.413 & 1.071 & 1.864 \\
\hline Ba ppm & 1340.882 & 446.195 & 1826.435 & 1425.876 \\
\hline Th ppm & 4.902 & 10.239 & 7.157 & 8.120 \\
\hline Nb ppm & 9.033 & 21.021 & 23.715 & 24.231 \\
\hline Y ppm & 10.290 & 26.845 & 63.079 & 106.601 \\
\hline Hf ppm & 3.739 & 3.641 & 10.298 & 12.231 \\
\hline Ta ppm & 0.700 & 1.983 & 1.469 & 1.477 \\
\hline U ppm & 1.429 & 3.385 & 3.475 & 3.626 \\
\hline Pb ppm & 17.117 & 12.475 & 14.702 & 17.944 \\
\hline Rb ppm & 6.854 & 97.363 & 76.314 & 88.897 \\
\hline Cs ppm & 0.323 & 6.470 & 2.740 & 3.000 \\
\hline Sr ppm & 566.233 & 35.102 & 44.973 & 37.172 \\
\hline Sc ppm & 9.156 & 8.026 & 2.260 & 4.048 \\
\hline Zr ppm & 150.494 & 110.557 & 407.138 & 457.901 \\
\hline
\end{tabular}


All other units that are not the Strawberry Rhyolites ICP-MS

\begin{tabular}{|c|c|c|c|}
\hline Sample ID & PFC1548 & MS-15-21A & MS-15-21B \\
\hline La ppm & 46.645 & 43.852 & 40.402 \\
\hline Ce ppm & 95.690 & 90.423 & 85.619 \\
\hline Pr ppm & 12.393 & 11.561 & 10.945 \\
\hline Nd ppm & 49.743 & 46.364 & 44.443 \\
\hline Sm ppm & 11.707 & 10.572 & 10.695 \\
\hline Eu ppm & 1.709 & 2.090 & 2.614 \\
\hline Gd ppm & 12.289 & 10.857 & 10.594 \\
\hline Tb ppm & 2.320 & 1.980 & 1.900 \\
\hline Dy ppm & 15.539 & 12.699 & 12.032 \\
\hline Ho ppm & 3.445 & 2.749 & 2.563 \\
\hline Er ppm & 10.215 & 7.905 & 7.343 \\
\hline Tm ppm & 1.597 & 1.196 & 1.103 \\
\hline Yb ppm & 10.460 & 7.723 & 7.104 \\
\hline Lu ppm & 1.707 & 1.235 & 1.125 \\
\hline Ba ppm & 1474.396 & 1632.830 & 1459.677 \\
\hline Th ppm & 7.806 & 7.264 & 6.550 \\
\hline Nb ppm & 23.504 & 21.402 & 20.949 \\
\hline Y ppm & 90.622 & 71.687 & 66.648 \\
\hline Hf ppm & 11.979 & 10.397 & 9.317 \\
\hline Ta ppm & 1.441 & 1.395 & 1.329 \\
\hline U ppm & 3.474 & 3.041 & 2.726 \\
\hline Pb ppm & 17.106 & 15.690 & 13.712 \\
\hline Rb ppm & 81.371 & 81.933 & 69.253 \\
\hline Cs ppm & 2.953 & 3.348 & 3.001 \\
\hline Sr ppm & 30.923 & 95.659 & 173.819 \\
\hline Sc ppm & 3.297 & 2.894 & 13.003 \\
\hline Zr ppm & 449.178 & 402.138 & 362.373 \\
\hline
\end{tabular}




\section{All other units that are not the Strawberry Rhyolites}

\begin{tabular}{|c|c|c|c|}
\hline Sample ID & CD1936A & SV-177A & SV-177B \\
\hline Quadrangle Unit & \multicolumn{3}{|l|}{$\mathrm{BC}$} \\
\hline Abbreviation & Tdit4 & Tdit & Tdit \\
\hline Latitude & 44.2457 & $44^{\circ} 0^{\prime} 33.00^{\prime \prime}$ & $44^{\circ} 0^{\prime} 33.00^{\prime \prime}$ \\
\hline $\begin{array}{l}\text { Longitude } \\
\text { Thin Section Available } \\
\text { Age Date }\end{array}$ & \multicolumn{3}{|l|}{ yes } \\
\hline XRF & \multicolumn{3}{|c|}{ Normalized Major Elements (Weight \%): } \\
\hline $\mathrm{SiO2}$ & 71.934 & 74.352 & 71.856 \\
\hline $\mathrm{TiO2}$ & 0.325 & 0.232 & 0.433 \\
\hline Al2O3 & 16.200 & 13.024 & 13.368 \\
\hline $\mathrm{FeO}^{*}$ & 2.259 & 2.383 & 4.451 \\
\hline MnO & 0.057 & 0.069 & 0.093 \\
\hline MgO & 1.539 & 0.042 & 0.217 \\
\hline $\mathrm{CaO}$ & 1.723 & 1.003 & 1.398 \\
\hline $\mathrm{Na2O}$ & 2.773 & 2.980 & 2.193 \\
\hline K2O & 3.141 & 5.888 & 5.893 \\
\hline $\mathrm{P2O5}$ & 0.050 & 0.027 & 0.097 \\
\hline *Pre Normalized Sum & 88.379 & & \\
\hline \multirow[t]{2}{*}{ LOI \% } & 11.240 & & \\
\hline & \multicolumn{3}{|c|}{ Unnormalized Trace Elements (ppm): } \\
\hline Ni & 1.397 & 3.100 & 3.100 \\
\hline $\mathrm{Cr}$ & 7.032 & 2.800 & 9.200 \\
\hline Sc & 6.434 & 3.500 & 10.100 \\
\hline $\mathbf{V}$ & 10.522 & 3.100 & 8.500 \\
\hline $\mathbf{B a}$ & 863.337 & 1618.600 & 1456.900 \\
\hline $\mathbf{R b}$ & 61.288 & 80.600 & 78.200 \\
\hline $\mathrm{Sr}$ & 134.663 & 96.100 & 133.700 \\
\hline $\mathbf{Z r}$ & 299.297 & 386.900 & 367.100 \\
\hline $\mathbf{Y}$ & 42.544 & 73.200 & 66.400 \\
\hline $\mathbf{N b}$ & 14.715 & 21.700 & 20.700 \\
\hline $\mathbf{G a}$ & 16.758 & 22.200 & 21.700 \\
\hline $\mathbf{C u}$ & 2.892 & 4.500 & 5.600 \\
\hline Zn & 66.384 & 145.600 & 143.200 \\
\hline $\mathbf{P b}$ & 14.561 & 16.300 & 16.100 \\
\hline $\mathbf{L a}$ & 30.470 & 44.500 & 38.400 \\
\hline $\mathrm{Ce}$ & 64.000 & 91.700 & 82.900 \\
\hline Th & 7.929 & 7.000 & 6.000 \\
\hline Nd & 27.182 & 44.200 & 42.500 \\
\hline $\mathbf{U}$ & 2.642 & 2.300 & 3.400 \\
\hline
\end{tabular}




\section{All other units that are not the Strawberry Rhyolites}

\begin{tabular}{|c|c|c|c|c|}
\hline Sample ID & MS-15-25A & CD18116 & \multicolumn{2}{|l|}{ MS-19-05 } \\
\hline Quadrangle Unit & JOJ & JOJ & $\mathrm{BC}$ & \\
\hline Abbreviation & Tdit2 & Tdit2 & Tdit4 & \\
\hline Latitude & 44.0049 & 44.0125 & 44.2450 & \\
\hline Longitude & -118.8377 & -118.8723 & -118.8095 & \\
\hline \multicolumn{5}{|c|}{ Thin Section Available } \\
\hline \multicolumn{5}{|c|}{ Age Date } \\
\hline XRF & \multicolumn{3}{|c|}{ Normalized Major Elements (Weight \%): } & \\
\hline $\mathrm{SiO2}$ & 75.597 & 63.155 & 68.913 & \\
\hline TiO2 & 0.214 & 1.575 & 0.997 & \\
\hline Al2O3 & 13.296 & 15.534 & 14.554 & \\
\hline $\mathrm{FeO}^{*}$ & 1.546 & 7.486 & 5.107 & \\
\hline MnO & 0.015 & 0.115 & 0.088 & \\
\hline MgO & 0.094 & 1.647 & 0.861 & \\
\hline $\mathrm{CaO}$ & 0.436 & 4.322 & 2.287 & \\
\hline $\mathrm{Na2O}$ & 4.722 & 3.622 & 3.563 & \\
\hline K2O & 4.059 & 1.732 & 3.313 & \\
\hline P2O5 & 0.022 & 0.811 & 0.316 & \\
\hline \multicolumn{2}{|c|}{ *Pre Normalized Sum } & 93.858 & 94.884 & \\
\hline LOI \% & 1.212 & 5.784 & 4.775 & \\
\hline \multicolumn{5}{|c|}{ Unnormalized Trace Elements (ppm): } \\
\hline $\mathbf{N i}$ & 2.383 & 7.900 & 0.743 & \\
\hline $\mathbf{C r}$ & 1.986 & 9.700 & 2.574 & \\
\hline Sc & 2.681 & 21.100 & 14.801 & \\
\hline $\mathbf{V}$ & 5.958 & 101.800 & 58.856 & \\
\hline $\mathbf{B a}$ & 1665.360 & 844.900 & 963.963 & \\
\hline $\mathbf{R b}$ & 73.283 & 38.906 & 65.378 & \\
\hline $\mathrm{Sr}$ & 89.767 & 345.500 & 211.860 & \\
\hline $\mathbf{Z r}$ & 423.200 & 231.944 & 306.985 & \\
\hline $\mathbf{Y}$ & 49.650 & 47.600 & 48.708 & \\
\hline $\mathbf{N b}$ & 23.137 & 15.300 & 19.454 & \\
\hline Ga & 22.740 & 20.000 & 20.147 & \\
\hline $\mathbf{C u}$ & 1.986 & 12.300 & 3.960 & \\
\hline $\mathbf{Z n}$ & 113.401 & 155.200 & 133.700 & \\
\hline $\mathbf{P b}$ & 14.796 & 10.200 & 13.118 & \\
\hline La & 30.783 & 31.900 & 37.917 & \\
\hline $\mathrm{Ce}$ & 64.049 & 63.600 & 74.547 & \\
\hline Th & 7.845 & 5.000 & 5.544 & \\
\hline Nd & 36.741 & 37.800 & 39.006 & \\
\hline $\mathbf{U}$ & 1.490 & 1.500 & 3.564 & 149 \\
\hline
\end{tabular}




\section{All other units that are not the Strawberry Rhyolites}

ICP-MS

\begin{tabular}{|c|c|c|}
\hline Sample ID & CD1936A & SV-177A SV-177B \\
\hline La ppm & 31.240 & \\
\hline Ce ppm & 69.789 & \\
\hline Pr ppm & 7.467 & \\
\hline Nd ppm & 28.127 & \\
\hline Sm ppm & 5.945 & \\
\hline Eu ppm & 0.986 & \\
\hline Gd ppm & 5.812 & \\
\hline Tb ppm & 1.038 & \\
\hline Dy ppm & 6.789 & \\
\hline Ho ppm & 1.453 & \\
\hline Er ppm & 4.372 & \\
\hline Tm ppm & 0.691 & \\
\hline Yb ppm & 4.518 & \\
\hline Lu ppm & 0.737 & \\
\hline Ba ppm & 896.197 & \\
\hline Th ppm & 8.238 & \\
\hline Nb ppm & 14.721 & \\
\hline Y ppm & 42.420 & \\
\hline Hf ppm & 7.606 & \\
\hline Ta ppm & 1.037 & \\
\hline U ppm & 2.963 & \\
\hline Pb ppm & 13.991 & \\
\hline Rb ppm & 59.786 & \\
\hline Cs ppm & 3.321 & \\
\hline Sr ppm & 133.381 & \\
\hline Sc ppm & 6.683 & \\
\hline Zr ppm & 297.562 & \\
\hline
\end{tabular}




\section{All other units that are not the Strawberry Rhyolites}

ICP-MS

\begin{tabular}{|c|c|c|c|}
\hline Sample ID & MS-15-25A & CD18116 & MS-19-05 \\
\hline La ppm & 37.237 & 30.486 & 36.807 \\
\hline Ce ppm & 67.450 & 65.332 & 76.465 \\
\hline Pr ppm & 9.816 & 8.740 & 9.852 \\
\hline Nd ppm & 39.288 & 37.257 & 40.233 \\
\hline Sm ppm & 8.959 & 8.601 & 9.150 \\
\hline Eu ppm & 2.156 & 2.481 & 2.126 \\
\hline Gd ppm & 8.410 & 8.604 & 9.016 \\
\hline Tb ppm & 1.493 & 1.456 & 1.523 \\
\hline Dy ppm & 9.450 & 8.981 & 9.249 \\
\hline Ho ppm & 1.950 & 1.836 & 1.954 \\
\hline Er ppm & 5.521 & 4.974 & 5.345 \\
\hline Tm ppm & 0.834 & 0.713 & 0.783 \\
\hline Yb ppm & 5.290 & 4.569 & 4.923 \\
\hline Lu ppm & 0.819 & 0.741 & 0.788 \\
\hline Ba ppm & 1733.603 & 846.618 & 981.683 \\
\hline Th ppm & 7.749 & 4.938 & 6.577 \\
\hline Nb ppm & 22.822 & 14.859 & 19.383 \\
\hline Y ppm & 49.117 & 47.151 & 49.212 \\
\hline Hf ppm & 11.196 & 6.102 & 8.040 \\
\hline Ta ppm & 1.449 & 0.995 & 1.282 \\
\hline U ppm & 2.406 & 2.578 & 2.808 \\
\hline Pb ppm & 14.299 & 9.413 & 12.758 \\
\hline Rb ppm & 71.915 & 41.050 & 64.316 \\
\hline Cs ppm & 1.495 & 1.580 & 2.926 \\
\hline Sr ppm & 94.478 & 345.392 & 210.671 \\
\hline Sc ppm & 2.794 & 21.615 & 14.734 \\
\hline Zr ppm & 433.472 & 237.256 & 311.453 \\
\hline
\end{tabular}


All other units that are not the Strawberry Rhyolites

\begin{tabular}{|c|c|c|c|c|c|}
\hline Sample ID & CD1982 & MS-18-01 & RS20MPT29 & ASSV111 & ASSV137 \\
\hline $\begin{array}{l}\text { Quadrangle Unit } \\
\text { Abbreviation Latitude } \\
\text { Longitude } \\
\text { Thin Section Available } \\
\text { Age Date }\end{array}$ & $\begin{array}{l}\text { BC } \\
\text { Tdct } \\
44.1704 \\
-118.8618\end{array}$ & $\begin{array}{l}\text { JOJ } \\
\text { Tdct } \\
44.0332 \\
-118.7516\end{array}$ & $\begin{array}{l}\text { MPT } \\
\text { Tdct } \\
44.0343 \\
-118.6958\end{array}$ & $\begin{array}{l}\text { Tdct } \\
44^{\circ} 5^{\prime} 45.90^{\prime \prime} \\
118^{\circ} 39^{\prime} 24.90^{\prime \prime}\end{array}$ & $\begin{array}{l}\text { Tdet } \\
44^{\circ} 7^{\prime} 45.00^{\prime \prime} \\
118^{\circ} 48^{\prime} 56.30^{\prime \prime}\end{array}$ \\
\hline XRF & \multicolumn{5}{|c|}{ Normalized Major Elements (Weight \%): } \\
\hline $\mathrm{SiO} 2$ & 77.040 & 76.906 & 76.978 & 76.624 & 76.994 \\
\hline TiO2 & 0.204 & 0.194 & 0.190 & 0.214 & 0.248 \\
\hline Al2O3 & 11.028 & 10.924 & 10.851 & 11.093 & 11.857 \\
\hline $\mathrm{FeO} *$ & 2.502 & 2.850 & 2.862 & 2.724 & 2.090 \\
\hline MnO & 0.053 & 0.061 & 0.054 & 0.044 & 0.035 \\
\hline MgO & 0.024 & 0.000 & 0.062 & 0.027 & 0.022 \\
\hline $\mathrm{CaO}$ & 0.108 & 0.171 & 0.160 & 0.152 & 0.350 \\
\hline $\mathrm{Na2O}$ & 3.906 & 3.884 & 3.574 & 3.577 & 2.959 \\
\hline K2O & 5.125 & 5.005 & 5.253 & 5.534 & 5.430 \\
\hline P2O5 & 0.009 & 0.006 & 0.015 & 0.012 & 0.014 \\
\hline *Pre Normalized Sum & 96.502 & 96.291 & 97.149 & & \\
\hline \multirow[t]{2}{*}{ LOI \% } & 3.001 & 2.988 & 2.157 & & \\
\hline & \multicolumn{5}{|c|}{ Unnormalized Trace Elements (ppm): } \\
\hline $\mathbf{N i}$ & 2.692 & 3.317 & 1.504 & 2.500 & 3.100 \\
\hline $\mathrm{Cr}$ & 3.141 & 2.513 & 2.638 & 3.800 & 4.300 \\
\hline Sc & 0.300 & 1.508 & 0.558 & 0.600 & 1.800 \\
\hline $\mathbf{V}$ & 2.790 & 0.000 & 3.957 & 3.600 & 5.500 \\
\hline $\mathbf{B a}$ & 49.352 & 36.281 & 53.969 & 60.700 & 592.300 \\
\hline $\mathbf{R b}$ & 122.529 & 137.112 & 132.407 & 117.100 & 112.100 \\
\hline $\mathrm{Sr}$ & 3.483 & 3.518 & 6.598 & 7.800 & 45.400 \\
\hline $\mathbf{Z r}$ & 1038.745 & 1182.684 & 1176.276 & 937.100 & 799.000 \\
\hline $\mathbf{Y}$ & 127.431 & 146.730 & 140.001 & 134.100 & 99.900 \\
\hline $\mathbf{N b}$ & 73.216 & 84.018 & 80.247 & 67.300 & 58.200 \\
\hline $\mathbf{G a}$ & 26.783 & 27.638 & 28.847 & 27.400 & 28.900 \\
\hline $\mathrm{Cu}$ & 4.938 & 5.729 & 11.109 & 5.800 & 3.700 \\
\hline Zn & 203.592 & 239.291 & 233.589 & 214.900 & 153.000 \\
\hline $\mathbf{P b}$ & 26.883 & 31.356 & 30.181 & 25.500 & 22.900 \\
\hline $\mathrm{Ce}$ & 100.400 & 103.616 & 87.500 & 106.600 & 101.600 \\
\hline La & 195.319 & 203.010 & 172.467 & 193.500 & 199.800 \\
\hline Th & 11.200 & 13.769 & 13.182 & 11.300 & 10.500 \\
\hline Nd & 96.600 & 93.063 & 91.564 & 97.600 & 94.500 \\
\hline $\mathbf{U}$ & 3.941 & 4.824 & 5.580 & 3.400 & 3.900 \\
\hline
\end{tabular}




\section{All other units that are not the Strawberry Rhyolites}

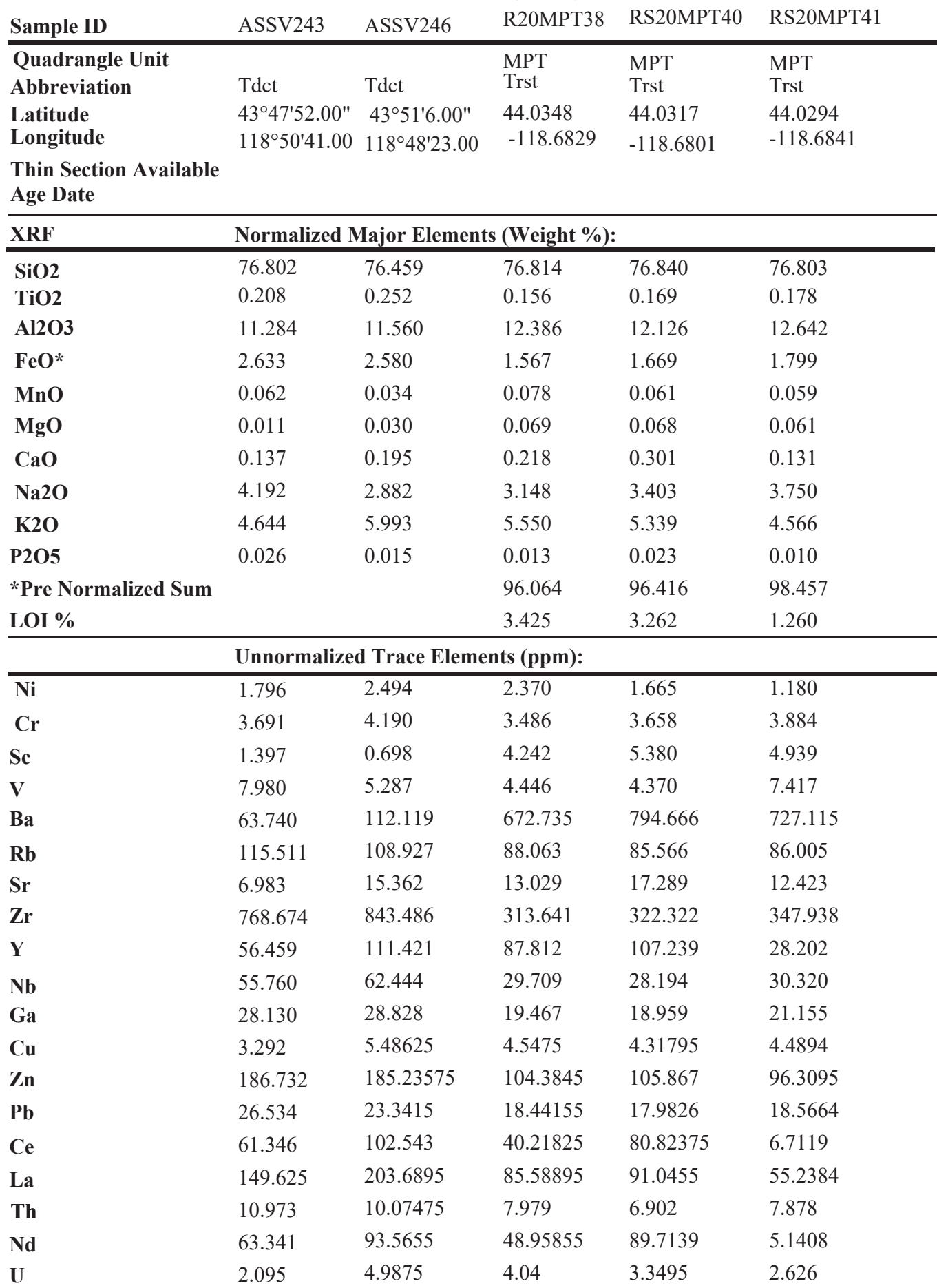


All other units that are not the Strawberry Rhyolites

\begin{tabular}{|c|c|c|c|c|c|}
\hline Sample ID & CD1982 & MS-18-01 & RS20MPT29 & ASSV111 & ASSV137 \\
\hline La ppm & 105.194 & 93.291 & 91.938 & & \\
\hline Ce ppm & 203.700 & 196.106 & 179.416 & & \\
\hline Pr ppm & 26.322 & 24.503 & 24.082 & & \\
\hline Nd ppm & 102.077 & 96.525 & 95.797 & & \\
\hline Sm ppm & 22.602 & 22.792 & 21.639 & & \\
\hline Eu ppm & 0.760 & 0.708 & 0.738 & & \\
\hline Gd ppm & 22.071 & 23.323 & 22.086 & & \\
\hline Tb ppm & 3.858 & 4.214 & 3.964 & & \\
\hline Dy ppm & 24.548 & 27.281 & 24.069 & & \\
\hline Ho ppm & 5.069 & 5.712 & 5.179 & & \\
\hline Er ppm & 14.410 & 16.231 & 14.850 & & \\
\hline Tm ppm & 2.147 & 2.422 & 2.373 & & \\
\hline Yb ppm & 13.621 & 15.422 & 15.022 & & \\
\hline Lu ppm & 2.148 & 2.444 & 2.363 & & \\
\hline Ba ppm & 48.516 & 32.785 & 55.542 & & \\
\hline Th ppm & 12.815 & 14.028 & 13.830 & & \\
\hline Nb ppm & 72.338 & 81.285 & 77.117 & & \\
\hline Y ppm & 129.322 & 146.711 & 141.561 & & \\
\hline Hf ppm & 23.257 & 25.936 & 25.580 & & \\
\hline Ta ppm & 4.435 & 5.017 & 4.919 & & \\
\hline U ppm & 4.885 & 5.537 & 5.477 & & \\
\hline Pb ppm & 26.773 & 31.142 & 30.484 & & \\
\hline Rb ppm & 123.335 & 142.296 & 132.333 & & \\
\hline Cs ppm & 3.586 & 4.113 & 4.135 & & \\
\hline Sr ppm & 4.665 & 4.771 & 9.048 & & \\
\hline Sc ppm & 0.088 & -0.703 & 0.546 & & \\
\hline Zr ppm & 1059.549 & 1194.361 & 1137.841 & & \\
\hline
\end{tabular}


All other units that are not the Strawberry Rhyolites

\begin{tabular}{|c|c|c|c|c|c|}
\hline Sample ID & ASSV243 & ASSV246 & R20MPT38 & RS20MPT40 & RS20MPT41 \\
\hline La ppm & & & 41.555497 & 83.223487 & 5.9748182 \\
\hline Ce ppm & & & 90.052112 & 93.020917 & 57.157703 \\
\hline Pr ppm & & & 12.606219 & 23.805329 & 1.4361753 \\
\hline Nd ppm & & & 50.135874 & 92.007588 & 5.7035934 \\
\hline Sm ppm & & & 12.515152 & 20.627517 & 1.7168892 \\
\hline Eu ppm & & & 1.3601718 & 2.9369858 & 0.8384912 \\
\hline Gd ppm & & & 12.951728 & 18.859818 & 2.3170839 \\
\hline Tb ppm & & & 2.4141557 & 3.3723211 & 0.5644298 \\
\hline Dy ppm & & & 14.856804 & 19.61154 & 4.0795974 \\
\hline Ho ppm & & & 3.2026928 & 4.019999 & 1.0286308 \\
\hline Er ppm & & & 9.1392972 & 11.045783 & 3.3631124 \\
\hline Tm ppm & & & 1.4474098 & 1.7248143 & 0.607205 \\
\hline Yb ppm & & & 9.3825811 & 10.941973 & 4.3813012 \\
\hline Lu ppm & & & 1.468861 & 1.6574712 & 0.7136439 \\
\hline Ba ppm & & & 692.33142 & 818.90193 & 755.37985 \\
\hline Th ppm & & & 8.1818275 & 7.7201341 & 8.4385259 \\
\hline Nb ppm & & & 28.723561 & 27.480509 & 29.753804 \\
\hline Y ppm & & & 87.576623 & 107.62645 & 28.604115 \\
\hline Hf ppm & & & 9.4664523 & 9.5235258 & 10.337887 \\
\hline Ta ppm & & & 1.8548662 & 1.7651473 & 1.8917641 \\
\hline $\mathbf{U} \mathbf{p p m}$ & & & 3.4898905 & 3.4251568 & 2.7920689 \\
\hline Pb ppm & & & 19.08714 & 18.169965 & 18.472452 \\
\hline Rb ppm & & & 88.288504 & 86.391573 & 85.523884 \\
\hline Cs ppm & & & 3.2895355 & 3.2331256 & 1.6976659 \\
\hline Sr ppm & & & 14.198155 & 19.64625 & 13.978138 \\
\hline Sc ppm & & & 4.397446 & 4.7496455 & 4.2588662 \\
\hline Zr ppm & & & 310.87636 & 324.58985 & 349.19829 \\
\hline
\end{tabular}




\section{All other units that are not the Strawberry Rhyolites}

\begin{tabular}{|c|c|c|c|c|c|}
\hline Sample ID & ASSV135 & CD1938 & BC19B36 & CD18125 & CD18109 \\
\hline $\begin{array}{l}\text { Quadrangle Unit } \\
\text { Abbreviation }\end{array}$ & Trst & $\begin{array}{l}\text { BC } \\
\text { Tbsv }\end{array}$ & $\begin{array}{l}\text { BC } \\
\text { Tbsv }\end{array}$ & $\begin{array}{l}\text { JOJ } \\
\text { Ttsb }\end{array}$ & $\begin{array}{l}\text { JOJ } \\
\text { Ttsb }\end{array}$ \\
\hline $\begin{array}{l}\text { Latitude } \\
\text { Longitude }\end{array}$ & $\begin{array}{l}44^{\circ} 10^{\prime} 4.10^{\prime \prime} \\
118^{\circ} 48^{\prime} 20.40\end{array}$ & $\begin{array}{l}44.2369 \\
-118.8475\end{array}$ & $\begin{array}{l}44.2454 \\
-118.8054\end{array}$ & $\begin{array}{l}44.0205 \\
-118.7582\end{array}$ & $\begin{array}{l}44.0067 \\
-118.8676\end{array}$ \\
\hline $\begin{array}{l}\text { Thin Section Available } \\
\text { Age Date }\end{array}$ & & & yes & & \\
\hline XRF & \multicolumn{5}{|c|}{ Normalized Major Elements (Weight \%): } \\
\hline $\mathrm{SiO2}$ & 76.864 & 50.722 & 50.903 & 53.560 & 50.757 \\
\hline TiO2 & 0.138 & 1.256 & 1.453 & 1.349 & 1.415 \\
\hline Al2O3 & 12.014 & 17.150 & 16.663 & 17.494 & 17.412 \\
\hline FeO* & 1.478 & 9.718 & 9.746 & 8.659 & 9.861 \\
\hline MnO & 0.068 & 0.118 & 0.158 & 0.143 & 0.182 \\
\hline MgO & 0.068 & 7.130 & 7.344 & 5.503 & 6.846 \\
\hline $\mathrm{CaO}$ & 0.299 & 10.320 & 9.543 & 8.835 & 9.224 \\
\hline $\mathrm{Na2O}$ & 2.743 & 2.693 & 2.996 & 3.218 & 3.166 \\
\hline K2O & 6.318 & 0.597 & 0.840 & 0.835 & 0.641 \\
\hline P2O5 & 0.011 & 0.297 & 0.353 & 0.404 & 0.495 \\
\hline *Pre Normalized Sum & & 95.682 & 98.964 & 98.047 & 97.567 \\
\hline LOI \% & & 3.889 & 0.621 & 1.628 & 1.789 \\
\hline \multicolumn{6}{|c|}{ Unnormalized Trace Elements (ppm): } \\
\hline $\mathbf{N i}$ & 2.600 & 142.200 & 138.787 & 49.949 & 93.331 \\
\hline $\mathrm{Cr}$ & 3.100 & 303.026 & 202.762 & 132.335 & 111.540 \\
\hline $\mathrm{Sc}$ & 3.600 & 31.699 & 27.038 & 25.572 & 26.268 \\
\hline $\mathbf{V}$ & 4.200 & 258.620 & 236.006 & 218.104 & 244.472 \\
\hline $\mathbf{B a}$ & 626.900 & 272.996 & 282.547 & 544.564 & 328.549 \\
\hline $\mathbf{R b}$ & 98.300 & 11.640 & 10.326 & 10.335 & 6.728 \\
\hline $\mathrm{Sr}$ & 12.700 & 372.977 & 469.747 & 516.604 & 521.878 \\
\hline $\mathbf{Z r}$ & 281.800 & 79.691 & 108.421 & 139.644 & 115.958 \\
\hline $\mathbf{Y}$ & 92.600 & 23.206 & 23.295 & 27.064 & 26.766 \\
\hline $\mathbf{N b}$ & 29.600 & 6.222 & 8.668 & 9.552 & 9.751 \\
\hline Ga & 19.900 & 16.293 & 17.927 & 18.607 & 18.806 \\
\hline $\mathrm{Cu}$ & 1.1 & 49.5735 & 63.730 & 24.378 & 67.063 \\
\hline Zn & 104 & 74.60725 & 86.188 & 99.500 & 99.003 \\
\hline $\mathbf{P b}$ & 20.7 & 2.079 & 3.054 & 5.871 & 4.975 \\
\hline $\mathrm{Ce}$ & 38.1 & 11.385 & 12.214 & 16.716 & 17.015 \\
\hline La & 86.2 & 24.428 & 30.289 & 42.984 & 40.198 \\
\hline Th & 7.2 & 0.394 & 0.690 & 1.791 & 0.697 \\
\hline Nd & 47.8 & 14.3326667 & 18.321 & 22.189 & 23.781 \\
\hline $\mathbf{U}$ & 2.9 & 0.83725 & 2.315 & 0.995 & 0.796 \\
\hline
\end{tabular}


All other units that are not the Strawberry Rhyolites

\begin{tabular}{|c|c|c|c|c|c|}
\hline Sample ID & ASSV135 & CD1938 & BC19B36 & CD18125 & CD18109 \\
\hline La ppm & & 11.0736761 & 13.179 & 18.837 & 16.296 \\
\hline Ce ppm & & 22.9207825 & 30.226 & 39.680 & 37.612 \\
\hline Pr ppm & & 3.25920014 & 4.091 & 5.231 & 5.151 \\
\hline Nd ppm & & 14.3894944 & 17.911 & 22.019 & 22.486 \\
\hline Sm ppm & & 3.38979263 & 4.465 & 5.080 & 5.144 \\
\hline Eu ppm & & 1.24086089 & 1.529 & 1.571 & 1.663 \\
\hline Gd ppm & & 3.88422533 & 4.653 & 4.956 & 5.053 \\
\hline Tb ppm & & 0.64218132 & 0.743 & 0.791 & 0.841 \\
\hline Dy ppm & & 4.03651582 & 4.537 & 4.781 & 4.987 \\
\hline Ho ppm & & 0.83836677 & 0.933 & 0.980 & 1.018 \\
\hline Er ppm & & 2.27083047 & 2.509 & 2.636 & 2.728 \\
\hline Tm ppm & & 0.31555406 & 0.349 & 0.384 & 0.383 \\
\hline Yb ppm & & 1.99349769 & 2.170 & 2.337 & 2.380 \\
\hline Lu ppm & & 0.29715845 & 0.330 & 0.380 & 0.382 \\
\hline Ba ppm & & 271.037211 & 277.653 & 542.830 & 319.866 \\
\hline Th ppm & & 0.69880809 & 0.979 & 1.608 & 0.726 \\
\hline Nb ppm & & 6.41768544 & 8.938 & 9.430 & 8.986 \\
\hline Y ppm & & 23.0709966 & 23.369 & 26.363 & 26.419 \\
\hline Hf ppm & & 2.02294347 & 2.719 & 3.429 & 2.823 \\
\hline Ta ppm & & 0.39414523 & 0.577 & 0.568 & 0.487 \\
\hline U ppm & & 0.26163232 & 0.347 & 0.489 & 0.263 \\
\hline Pb ppm & & 1.94870467 & 2.451 & 4.648 & 3.024 \\
\hline Rb ppm & & 10.3883791 & 7.461 & 9.478 & 6.466 \\
\hline Cs ppm & & 0.90635427 & 0.206 & 0.389 & 0.206 \\
\hline Sr ppm & & 377.65969 & 473.049 & 522.060 & 533.534 \\
\hline Sc ppm & & 31.0101284 & 27.586 & 25.115 & 28.655 \\
\hline Zr ppm & & 80.2670699 & 109.208 & 141.569 & 119.184 \\
\hline
\end{tabular}




\section{All other units that are not the Strawberry Rhyolites}

\begin{tabular}{|c|c|c|c|c|c|}
\hline Sample ID & SW-JJ17-9 & MS-17-08 & BC19B07 & BC19C15 & MS-15-23A \\
\hline Quadrangle Unit & JOJ & JOJ & $\mathrm{BC}$ & $\mathrm{BC}$ & JOJ \\
\hline Abbreviation & Ttsb & Ttsb & Tvpd & Tvpd & Tvpd \\
\hline Latitude & 44.0225 & 44.1154 & 44.2285 & 44.2020 & 44.0086 \\
\hline Longitude & -118.8406 & -118.8712 & -118.8135 & -118.7922 & -118.8280 \\
\hline $\begin{array}{l}\text { Thin Section Available } \\
\text { Age Date }\end{array}$ & & & yes & yes & \\
\hline XRF & \multicolumn{5}{|c|}{ Normalized Major Elements (Weight \%): } \\
\hline $\mathrm{SiO2}$ & 50.265 & 48.922 & 53.655 & 54.399 & 59.588 \\
\hline TiO2 & 1.453 & 1.108 & 1.439 & 1.254 & 1.859 \\
\hline Al2O3 & 17.262 & 17.923 & 17.354 & 16.703 & 15.304 \\
\hline $\mathrm{FeO}^{*}$ & 10.484 & 10.117 & 9.856 & 8.603 & 8.921 \\
\hline MnO & 0.179 & 0.285 & 0.166 & 0.163 & 0.176 \\
\hline MgO & 6.415 & 9.211 & 4.887 & 5.789 & 1.791 \\
\hline $\mathrm{CaO}$ & 9.284 & 9.316 & 8.459 & 7.981 & 5.383 \\
\hline $\mathrm{Na2O}$ & 3.423 & 2.694 & 3.143 & 3.464 & 3.872 \\
\hline K2O & 0.674 & 0.287 & 0.626 & 1.116 & 1.989 \\
\hline P2O5 & 0.559 & 0.136 & 0.415 & 0.527 & 1.118 \\
\hline *Pre Normalized Sum & 98.203 & 96.126 & 94.132 & 98.922 & 95.122 \\
\hline \multirow[t]{2}{*}{ LOI \% } & 1.051 & 3.394 & 5.392 & 0.522 & 3.716 \\
\hline & \multicolumn{5}{|c|}{ Unnormalized Trace Elements (ppm): } \\
\hline$\overline{\mathrm{Ni}}$ & 97.220 & 147.980 & 72.602 & 108.429 & 5.462 \\
\hline $\mathrm{Cr}$ & 87.961 & 147.882 & 128.726 & 176.065 & 1.192 \\
\hline Sc & 26.891 & 33.908 & 24.439 & 23.422 & 22.740 \\
\hline $\mathbf{V}$ & 240.931 & 186.298 & 140.842 & 191.600 & 114.096 \\
\hline $\mathrm{Ba}$ & 382.968 & 149.548 & 479.259 & 597.729 & 1004.916 \\
\hline $\mathbf{R b}$ & 7.913 & 4.320 & 5.363 & 11.310 & 45.479 \\
\hline $\mathrm{Sr}$ & 573.432 & 313.074 & 520.515 & 515.702 & 406.832 \\
\hline $\mathbf{Z r}$ & 125.395 & 75.362 & 113.972 & 153.622 & 196.300 \\
\hline $\mathbf{Y}$ & 27.876 & 24.794 & 23.571 & 32.604 & 42.997 \\
\hline $\mathbf{N b}$ & 10.540 & 1.666 & 7.395 & 11.612 & 13.406 \\
\hline Ga & 18.223 & 14.896 & 17.519 & 17.913 & 18.867 \\
\hline $\mathrm{Cu}$ & 75.550 & 71.442 & 45.358 & 34.091 & 8.341 \\
\hline $\mathbf{Z n}$ & 101.554 & 71.148 & 90.764 & 90.865 & 124.423 \\
\hline $\mathbf{P b}$ & 3.152 & 2.352 & 3.582 & 5.308 & 6.057 \\
\hline $\mathrm{Ce}$ & 17.238 & 2.450 & 15.433 & 27.540 & 26.910 \\
\hline La & 43.439 & 15.288 & 29.284 & 48.140 & 60.970 \\
\hline Th & 1.281 & 0.392 & 0.990 & 1.683 & 4.071 \\
\hline Nd & 23.246 & 12.054 & 19.005 & 27.691 & 35.649 \\
\hline $\mathbf{U}$ & 2.561 & 0.490 & 1.787 & 1.391 & 3.575 \\
\hline
\end{tabular}


All other units that are not the Strawberry Rhyolites

\begin{tabular}{|c|c|c|c|c|c|}
\hline Sample ID & SW-JJ17-9 & MS-17-08 & ВС19B07 & BC19C15 & MS-15-23A \\
\hline La ppm & 17.432 & 5.578 & 14.962 & 27.255 & 28.832 \\
\hline Ce ppm & 41.095 & 14.523 & 30.852 & 47.644 & 63.084 \\
\hline Pr ppm & 5.712 & 2.218 & 4.460 & 7.045 & 8.583 \\
\hline Nd ppm & 24.415 & 10.392 & 19.076 & 28.919 & 36.769 \\
\hline Sm ppm & 5.646 & 2.972 & 4.624 & 6.335 & 8.670 \\
\hline Eu ppm & 1.781 & 1.194 & 1.480 & 1.937 & 2.837 \\
\hline Gd ppm & 5.462 & 3.659 & 4.624 & 6.277 & 8.649 \\
\hline Tb ppm & 0.901 & 0.670 & 0.726 & 0.993 & 1.392 \\
\hline Dy ppm & 5.424 & 4.486 & 4.441 & 5.902 & 8.430 \\
\hline Ho ppm & 1.086 & 0.985 & 0.901 & 1.233 & 1.710 \\
\hline Er ppm & 2.936 & 2.821 & 2.461 & 3.191 & 4.617 \\
\hline Tm ppm & 0.417 & 0.406 & 0.347 & 0.463 & 0.654 \\
\hline Yb ppm & 2.607 & 2.637 & 2.189 & 2.947 & 4.075 \\
\hline Lu ppm & 0.405 & 0.414 & 0.346 & 0.476 & 0.646 \\
\hline Ba ppm & 384.085 & 143.619 & 483.873 & 591.303 & 1028.849 \\
\hline Th ppm & 0.620 & 0.370 & 1.166 & 1.785 & 4.039 \\
\hline Nb ppm & 9.685 & 1.846 & 7.715 & 11.803 & 13.878 \\
\hline Y ppm & 27.703 & 24.825 & 23.656 & 32.171 & 44.029 \\
\hline Hf ppm & 2.993 & 1.921 & 2.763 & 3.624 & 5.217 \\
\hline Ta ppm & 0.515 & 0.130 & 0.481 & 0.677 & 0.917 \\
\hline U ppm & 0.229 & 0.132 & 0.406 & 0.560 & 2.370 \\
\hline Pb ppm & 2.793 & 1.172 & 3.479 & 5.403 & 7.211 \\
\hline Rb ppm & 5.962 & 2.964 & 2.217 & 9.619 & 44.662 \\
\hline Cs ppm & 0.137 & 0.516 & 0.190 & 0.176 & 2.030 \\
\hline Sr ppm & 579.232 & 319.205 & 513.660 & 516.355 & 417.106 \\
\hline Sc ppm & 27.112 & 35.797 & 24.339 & 22.760 & 23.960 \\
\hline Zr ppm & 123.593 & 76.502 & 114.492 & 153.640 & 202.141 \\
\hline
\end{tabular}




\section{All other units that are not the Strawberry Rhyolites}

\begin{tabular}{|c|c|c|c|c|c|}
\hline Sample ID & MS-15-23B & MS-15-23C & MS-18-03b & MS-14-17 & CD1972 \\
\hline Quadrangle Unit & JOJ & JOJ & JOJ & JOJ & $\mathrm{BC}$ \\
\hline Abbreviation & Tvpd & Tvpd & Tvpd & Tvpd & Tasv \\
\hline Latitude & 44.0086 & 44.0086 & 44.0293 & 44.0118 & 44.1867 \\
\hline Longitude & -118.8280 & -118.8280 & -118.7967 & -118.8410 & -118.7853 \\
\hline \multicolumn{6}{|l|}{$\begin{array}{l}\text { Thin Section Available } \\
\text { Age Date }\end{array}$} \\
\hline XRF & \multicolumn{5}{|c|}{ Normalized Major Elements (Weight \%): } \\
\hline $\mathrm{SiO2}$ & 59.782 & 57.906 & 61.793 & 59.582 & 61.170 \\
\hline TiO2 & 1.875 & 1.838 & 1.905 & 1.933 & 1.000 \\
\hline $\mathrm{Al2O3}$ & 15.000 & 16.088 & 16.242 & 15.255 & 16.104 \\
\hline $\mathrm{FeO} *$ & 9.102 & 9.362 & 6.228 & 9.068 & 6.672 \\
\hline MnO & 0.172 & 0.185 & 0.113 & 0.171 & 0.127 \\
\hline MgO & 1.932 & 1.514 & 0.696 & 1.842 & 2.849 \\
\hline $\mathrm{CaO}$ & 5.194 & 5.766 & 5.154 & 5.095 & 6.193 \\
\hline $\mathrm{Na2O}$ & 4.254 & 4.323 & 4.324 & 4.274 & 3.747 \\
\hline $\mathrm{K} 2 \mathrm{O}$ & 1.811 & 1.395 & 2.156 & 1.912 & 1.790 \\
\hline P2O5 & 0.879 & 1.623 & 1.390 & 0.868 & 0.348 \\
\hline *Pre Normalized Sum & 97.661 & 94.647 & 95.040 & 97.461 & 99.531 \\
\hline \multirow[t]{2}{*}{ LOI \% } & 2.235 & 5.205 & 4.204 & & 0.000 \\
\hline & \multicolumn{5}{|c|}{ Unnormalized Trace Elements (ppm): } \\
\hline $\mathbf{N i}$ & 7.348 & 7.979 & 7.700 & 5.174 & 8.767 \\
\hline $\mathrm{Cr}$ & 0.000 & 0.000 & 2.700 & 12.040 & 17.139 \\
\hline Sc & 24.130 & 24.231 & 24.600 & 24.179 & 18.124 \\
\hline $\mathbf{V}$ & 120.054 & 66.094 & 114.300 & 135.818 & 155.778 \\
\hline $\mathbf{B a}$ & 1072.043 & 1106.057 & 1183.500 & 998.284 & 901.571 \\
\hline $\mathbf{R b}$ & 38.826 & 11.525 & 41.062 & 37.313 & 35.367 \\
\hline $\mathrm{Sr}$ & 415.769 & 411.336 & 427.100 & 409.343 & 456.400 \\
\hline $\mathbf{Z r}$ & 192.300 & 208.100 & 211.761 & 196.513 & 147.569 \\
\hline $\mathbf{Y}$ & 42.401 & 51.713 & 74.700 & 47.462 & 25.758 \\
\hline $\mathbf{N b}$ & 13.505 & 15.169 & 15.100 & 14.428 & 8.126 \\
\hline Ga & 19.264 & 19.799 & 20.800 & 19.502 & 17.878 \\
\hline $\mathrm{Cu}$ & 7.050 & 9.653 & 9.800 & 11.542 & 19.700 \\
\hline $\mathrm{Zn}$ & 133.360 & 122.633 & 130.600 & 145.071 & 80.524 \\
\hline $\mathbf{P b}$ & 8.043 & 6.895 & 8.000 & 8.756 & 8.274 \\
\hline $\mathrm{Ce}$ & 27.605 & 30.732 & 38.600 & 31.044 & 19.306 \\
\hline La & 59.183 & 67.177 & 69.500 & 58.506 & 44.768 \\
\hline Th & 3.078 & 4.137 & 4.500 & 3.881 & 2.955 \\
\hline Nd & 33.266 & 40.287 & 49.900 & 38.706 & 22.458 \\
\hline $\mathbf{U}$ & 2.681 & 3.349 & 3.500 & 0.597 & 1.970 \\
\hline
\end{tabular}


All other units that are not the Strawberry Rhyolites

\begin{tabular}{|c|c|c|c|c|c|}
\hline Sample ID & MS-15-23B & MS-15-23C & MS-18-03b & MS-14-17 & CD1972 \\
\hline La ppm & 27.825 & 34.400 & 40.496 & 29.618 & 21.278 \\
\hline Ce ppm & 61.222 & 65.752 & 72.990 & 60.435 & 43.241 \\
\hline Pr ppm & 8.413 & 9.770 & 11.504 & 8.879 & 5.505 \\
\hline Nd ppm & 36.436 & 41.488 & 50.235 & 38.263 & 22.217 \\
\hline Sm ppm & 8.609 & 9.656 & 11.835 & 9.183 & 5.006 \\
\hline Eu ppm & 2.878 & 3.004 & 3.587 & 2.929 & 1.445 \\
\hline Gd ppm & 8.489 & 9.524 & 12.778 & 9.500 & 4.826 \\
\hline Tb ppm & 1.381 & 1.562 & 2.111 & 1.514 & 0.772 \\
\hline Dy ppm & 8.475 & 9.487 & 13.155 & 9.101 & 4.862 \\
\hline Ho ppm & 1.687 & 1.971 & 2.730 & 1.858 & 0.975 \\
\hline Er ppm & 4.525 & 5.299 & 7.533 & 5.035 & 2.618 \\
\hline Tm ppm & 0.634 & 0.755 & 1.111 & 0.719 & 0.385 \\
\hline Yb ppm & 3.868 & 4.717 & 7.190 & 4.521 & 2.381 \\
\hline Lu ppm & 0.625 & 0.760 & 1.178 & 0.702 & 0.362 \\
\hline Ba ppm & 1094.390 & 1148.062 & 1193.803 & 1000.155 & 906.442 \\
\hline Th ppm & 3.801 & 4.162 & 4.197 & 3.884 & 3.113 \\
\hline Nb ppm & 13.599 & 14.883 & 14.715 & 13.282 & 8.202 \\
\hline Y ppm & 43.438 & 52.538 & 75.805 & 46.916 & 25.334 \\
\hline Hf ppm & 5.023 & 5.525 & 5.531 & 4.979 & 3.761 \\
\hline Ta ppm & 0.842 & 0.913 & 0.930 & 0.859 & 0.549 \\
\hline U ppm & 1.739 & 3.535 & 3.274 & 1.895 & 1.132 \\
\hline Pb ppm & 7.636 & 5.867 & 7.032 & 7.731 & 7.493 \\
\hline Rb ppm & 37.934 & 10.848 & 43.603 & 35.821 & 34.851 \\
\hline Cs ppm & 2.432 & 0.401 & 1.482 & 1.811 & 1.092 \\
\hline Sr ppm & 431.272 & 428.313 & 433.078 & 409.783 & 461.810 \\
\hline Sc ppm & 25.178 & 24.978 & 26.766 & 24.614 & 18.639 \\
\hline $\mathrm{Zr} \mathrm{ppm}$ & 197.761 & 214.302 & 217.865 & 193.056 & 147.850 \\
\hline
\end{tabular}




\begin{tabular}{|c|c|c|c|c|c|}
\hline Sample ID & ВC19A22 & BC19B45 & CD1852 & CD1841 & CD18124 \\
\hline Quadrangle & $\mathrm{BC}$ & $\mathrm{BC}$ & $\mathrm{JJO}$ & JJO & JJO \\
\hline Unit Abbreviation & Tasv & Tasv & Tsva & Tsva & Tsva \\
\hline Latitude & 44.1911 & 44.2370 & 44.1093 & 44.0926 & 44.1087 \\
\hline Longitude & & & & -118.8229 & -118.7829 \\
\hline Thin Section & \multirow[t]{2}{*}{ yes } & \multirow[t]{2}{*}{ yes } & & & \\
\hline Available Age Date & & & $\sim 16-12 \mathrm{ma}$ & $\sim 16-12 \mathrm{ma}$ & $\sim 16-12 \mathrm{ma}$ \\
\hline XRF & \multicolumn{5}{|c|}{ Normalized Major Elements (Weight \%): } \\
\hline $\mathrm{SiO2}$ & 60.868 & 62.276 & 61.279 & 62.456 & 59.167 \\
\hline TiO2 & 1.010 & 0.731 & 1.318 & 0.763 & 0.869 \\
\hline Al2O3 & 16.085 & 16.481 & 15.714 & 16.582 & 18.155 \\
\hline $\mathrm{FeO}^{*}$ & 6.811 & 5.593 & 7.193 & 5.457 & 6.568 \\
\hline MnO & 0.131 & 0.111 & 0.141 & 0.102 & 0.146 \\
\hline MgO & 2.923 & 3.011 & 2.417 & 3.019 & 3.819 \\
\hline $\mathrm{CaO}$ & 6.262 & 5.993 & 5.557 & 5.718 & 6.409 \\
\hline $\mathrm{Na2O}$ & 3.780 & 3.484 & 3.918 & 3.372 & 3.347 \\
\hline K2O & 1.773 & 2.047 & 1.956 & 2.310 & 1.289 \\
\hline P2O5 & 0.358 & 0.273 & 0.508 & 0.221 & 0.231 \\
\hline *Pre Normalized Sum & 99.483 & 97.052 & 99.124 & 98.326 & 97.722 \\
\hline \multirow[t]{2}{*}{ LOI \% } & 0.000 & 2.626 & 0.289 & 1.144 & 2.008 \\
\hline & \multicolumn{5}{|c|}{ Unnormalized Trace Elements (ppm): } \\
\hline $\mathbf{N i}$ & 11.623 & 27.770 & 6.965 & 35.621 & 46.069 \\
\hline $\mathrm{Cr}$ & 22.015 & 48.659 & 13.234 & 60.098 & 75.322 \\
\hline Sc & 18.272 & 15.741 & 17.612 & 17.114 & 21.890 \\
\hline $\mathbf{V}$ & 150.213 & 120.830 & 141.788 & 128.256 & 121.092 \\
\hline Ba & 884.727 & 894.465 & 949.031 & 818.587 & 701.077 \\
\hline $\mathbf{R b}$ & 35.271 & 38.703 & 35.393 & 45.435 & 22.133 \\
\hline $\mathrm{Sr}$ & 459.650 & 460.152 & 442.875 & 378.100 & 410.438 \\
\hline $\mathbf{Z r}$ & 148.538 & 167.889 & 179.498 & 157.357 & 150.148 \\
\hline $\mathbf{Y}$ & 25.462 & 23.018 & 33.731 & 23.980 & 25.273 \\
\hline $\mathbf{N b}$ & 8.520 & 8.712 & 11.940 & 7.463 & 7.562 \\
\hline $\mathbf{G a}$ & 18.617 & 16.880 & 19.502 & 17.114 & 18.806 \\
\hline $\mathrm{Cu}$ & 20.390 & 35.442 & 13.831 & 28.457 & 22.487 \\
\hline Zn & 81.854 & 70.488 & 96.913 & 65.372 & 77.411 \\
\hline $\mathbf{P b}$ & 7.782 & 8.514 & 8.557 & 8.259 & 6.070 \\
\hline $\mathrm{Ce}$ & 22.261 & 23.562 & 26.268 & 15.622 & 25.870 \\
\hline La & 41.961 & 46.184 & 53.034 & 45.472 & 39.303 \\
\hline Th & 2.463 & 3.366 & 3.483 & 4.179 & 3.085 \\
\hline Nd & 22.951 & 22.671 & 28.955 & 22.388 & 25.373 \\
\hline $\mathbf{U}$ & 2.906 & 2.376 & 2.587 & 2.090 & 1.095 \\
\hline
\end{tabular}




\section{All other units that are not the Strawberry Rhyolites}

\begin{tabular}{|c|c|c|c|c|c|}
\hline Sample ID & BC19A22 & BC19B45 & CD1852 & CD1841 & CD18124 \\
\hline La ppm & 21.985 & 24.540 & 25.530 & 20.531 & 24.533 \\
\hline Ce ppm & 43.834 & 48.097 & 52.854 & 40.785 & 42.092 \\
\hline Pr ppm & 5.768 & 5.833 & 6.850 & 5.060 & 6.266 \\
\hline Nd ppm & 23.231 & 22.615 & 28.182 & 20.214 & 24.361 \\
\hline Sm ppm & 5.048 & 4.666 & 6.266 & 4.346 & 5.265 \\
\hline Eu ppm & 1.498 & 1.277 & 1.828 & 1.199 & 1.438 \\
\hline Gd ppm & 5.013 & 4.345 & 6.161 & 4.189 & 4.851 \\
\hline Tb ppm & 0.810 & 0.673 & 1.018 & 0.707 & 0.805 \\
\hline Dy ppm & 5.001 & 4.254 & 6.255 & 4.330 & 4.906 \\
\hline Ho ppm & 1.004 & 0.853 & 1.270 & 0.866 & 0.945 \\
\hline Er ppm & 2.722 & 2.383 & 3.371 & 2.481 & 2.567 \\
\hline Tm ppm & 0.386 & 0.352 & 0.496 & 0.372 & 0.387 \\
\hline Yb ppm & 2.490 & 2.175 & 3.119 & 2.317 & 2.383 \\
\hline Lu ppm & 0.390 & 0.357 & 0.486 & 0.369 & 0.374 \\
\hline Ba ppm & 894.734 & 899.461 & 951.601 & 820.942 & 699.120 \\
\hline Th ppm & 3.081 & 3.561 & 3.306 & 3.938 & 3.529 \\
\hline Nb ppm & 8.414 & 9.047 & 11.619 & 7.811 & 7.339 \\
\hline Y ppm & 26.431 & 23.002 & 32.627 & 23.293 & 24.783 \\
\hline Hf ppm & 3.754 & 4.146 & 4.512 & 3.992 & 3.802 \\
\hline Ta ppm & 0.548 & 0.592 & 0.745 & 0.549 & 0.500 \\
\hline U ppm & 1.174 & 1.300 & 1.319 & 1.477 & 1.212 \\
\hline Pb ppm & 7.557 & 8.577 & 7.937 & 8.074 & 6.308 \\
\hline Rb ppm & 34.472 & 35.529 & 36.490 & 47.086 & 22.880 \\
\hline Cs ppm & 1.123 & 1.158 & 1.244 & 1.472 & 0.796 \\
\hline Sr ppm & 467.606 & 452.055 & 440.685 & 379.533 & 417.871 \\
\hline Sc ppm & 18.712 & 15.731 & 18.723 & 17.644 & 21.749 \\
\hline Zr ppm & 149.957 & 169.393 & 183.390 & 160.796 & 153.737 \\
\hline
\end{tabular}




\section{All other units that are not the Strawberry Rhyolites}

\begin{tabular}{|c|c|c|c|}
\hline Sample ID & BC19A45 & BC19A01 & BC19A07 \\
\hline Quadrangle & $\mathrm{BC}$ & $\mathrm{BC}$ & $\mathrm{BC}$ \\
\hline Unit Abbreviation & Itss & Itss & $\mathrm{Kpm}$ \\
\hline Latitude & 44.2224 & 44.2073 & 44.2206 \\
\hline Longitude & -118.8697 & -118.8715 & -118.8681 \\
\hline $\begin{array}{l}\text { Thin Section Available } \\
\text { Age Date }\end{array}$ & yes & yes & yes \\
\hline XRF & \multicolumn{3}{|c|}{ Normalized Major Elements (Weight \%): } \\
\hline $\mathrm{SiO2}$ & 57.907 & 71.255 & 47.492 \\
\hline TiO2 & 0.904 & 0.553 & 0.012 \\
\hline $\mathrm{Al2O3}$ & 16.515 & 13.864 & 0.843 \\
\hline $\mathrm{FeO}^{*}$ & 7.347 & 2.995 & 8.560 \\
\hline MnO & 0.148 & 0.039 & 0.250 \\
\hline MgO & 3.751 & 1.378 & 42.604 \\
\hline $\mathrm{CaO}$ & 7.550 & 5.918 & 0.209 \\
\hline $\mathrm{Na2O}$ & 3.699 & 1.722 & 0.000 \\
\hline $\mathrm{K} 2 \mathrm{O}$ & 2.003 & 2.149 & 0.015 \\
\hline P2O5 & 0.176 & 0.128 & 0.016 \\
\hline *Pre Normalized Sum & 94.368 & 95.888 & 84.444 \\
\hline \multirow[t]{2}{*}{ LOI \% } & 5.114 & 3.613 & 14.399 \\
\hline & \multicolumn{3}{|c|}{ Unnormalized Trace Elements (ppm): } \\
\hline$\overline{\mathrm{Ni}}$ & 15.821 & 11.406 & 2233.479 \\
\hline $\mathbf{C r}$ & 41.939 & 20.689 & 2872.008 \\
\hline Sc & 24.527 & 14.317 & 11.250 \\
\hline $\mathbf{V}$ & 178.652 & 83.687 & 44.521 \\
\hline Ba & 697.296 & 362.417 & 31.419 \\
\hline $\mathbf{R b}$ & 73.954 & 86.930 & 2.419 \\
\hline $\mathrm{Sr}$ & 442.924 & 383.543 & 5.900 \\
\hline $\mathbf{Z r}$ & 148.552 & 141.657 & 7.195 \\
\hline $\mathbf{Y}$ & 26.766 & 24.886 & 2.332 \\
\hline $\mathbf{N b}$ & 4.229 & 3.949 & 0.000 \\
\hline $\mathbf{G a}$ & 16.318 & 13.873 & 2.538 \\
\hline $\mathrm{Cu}$ & 44.526 & 29.528 & 8.506 \\
\hline $\mathbf{Z n}$ & 70.446 & 55.891 & 59.065 \\
\hline $\mathbf{P b}$ & 7.761 & 8.739 & 1.235 \\
\hline $\mathrm{Ce}$ & 12.537 & 13.563 & 0.823 \\
\hline La & 27.114 & 22.557 & 0.137 \\
\hline Th & 5.274 & 6.565 & 0.137 \\
\hline Nd & 15.323 & 13.790 & 0.000 \\
\hline $\mathbf{U}$ & 2.736 & 3.013 & 1.372 \\
\hline
\end{tabular}




\section{All other units that are not the Strawberry Rhyolites}

\begin{tabular}{|c|c|c|c|}
\hline Sample ID & ВC19A45 & BC19A01 & ВС19A07 \\
\hline La ppm & 12.179 & 12.040 & 0.319 \\
\hline Ce ppm & 26.991 & 25.967 & 0.142 \\
\hline Pr ppm & 3.678 & 3.514 & 0.087 \\
\hline Nd ppm & 15.722 & 14.918 & 0.426 \\
\hline Sm ppm & 4.176 & 3.829 & 0.102 \\
\hline Eu ppm & 1.039 & 0.918 & 0.028 \\
\hline Gd ppm & 4.398 & 4.058 & 0.123 \\
\hline Tb ppm & 0.751 & 0.686 & 0.021 \\
\hline Dy ppm & 4.770 & 4.563 & 0.116 \\
\hline Ho ppm & 1.015 & 0.957 & 0.023 \\
\hline Er ppm & 2.902 & 2.630 & 0.065 \\
\hline Tm ppm & 0.426 & 0.401 & 0.010 \\
\hline Yb ppm & 2.650 & 2.635 & 0.059 \\
\hline Lu ppm & 0.426 & 0.412 & 0.007 \\
\hline Ba ppm & 691.180 & 361.522 & 22.840 \\
\hline Th ppm & 5.395 & 6.419 & 0.041 \\
\hline Nb ppm & 4.233 & 3.891 & 0.080 \\
\hline Y ppm & 27.199 & 24.874 & 0.906 \\
\hline Hf ppm & 4.075 & 4.107 & 0.013 \\
\hline Ta ppm & 0.329 & 0.349 & 0.027 \\
\hline U ppm & 2.443 & 2.936 & 0.003 \\
\hline Pb ppm & 7.839 & 8.789 & 0.013 \\
\hline Rb ppm & 72.874 & 83.991 & -0.588 \\
\hline Cs ppm & 6.328 & 1.617 & \\
\hline Sr ppm & 442.569 & 377.046 & 6.816 \\
\hline Sc ppm & 24.982 & 13.738 & 11.634 \\
\hline $\mathrm{Zr}$ ppm & 149.497 & 141.163 & 1.740 \\
\hline
\end{tabular}




\section{APPENDIX B:}

\section{Actual Area Sums per Outcrop Mapped}

Table showing the actual calculated values of each unit by their outcrops determined by field mapping. Geometry for the areas was calculated using the sum of each units' polygon produced in ArcMap. Unit thicknesses and volume are estimates, which allow an average volume per unit to be estimated. 
*Area values are for the true field mapped polygons generated in ArcMap

\begin{tabular}{|c|c|c|c|c|c|c|c|}
\hline & \multirow[t]{2}{*}{ Unit Name } & \multirow[t]{2}{*}{$\begin{array}{c}\text { Area Sum } \\
(\mathrm{Km} 2)\end{array}$} & \multicolumn{2}{|c|}{$\begin{array}{c}\text { Estimated } \\
\text { Unit } \\
\text { Thickness } \\
\text { (m) }\end{array}$} & \multicolumn{2}{|c|}{$\begin{array}{c}\text { Estimated } \\
\text { Volume } \\
\text { (Km3) }\end{array}$} & \multirow[b]{2}{*}{$\begin{array}{c}\text { Average } \\
\text { Volume (km3) }\end{array}$} \\
\hline & & & Min & Max & Min & Max & \\
\hline Qa & Alluvium & 35.52 & 0.10 & 1.00 & 0.00 & 0.04 & 0.02 \\
\hline Trst & Rattlesnake Tuff & 13.96 & 5.00 & 20.00 & 0.07 & 0.28 & 0.17 \\
\hline Tdet & Devine Canyon Tuff & 7.27 & 5.00 & 15.00 & 0.04 & 0.11 & 0.07 \\
\hline Tbsv & Basalt to Basaltic Andesite & 2.22 & 3.00 & 30.00 & 0.01 & 0.07 & 0.04 \\
\hline Tpvd & Near Vent Pyroclastic Deposits & 1.53 & 3.00 & 10.00 & 0.00 & 0.02 & 0.01 \\
\hline Tasv & Andesite of Strawberry Volcanics & 163.66 & 5.00 & 180.00 & 0.82 & 29.46 & 15.14 \\
\hline Ttms & Milk Spring Tuff & 5.49 & 5.00 & 30.00 & 0.03 & 0.16 & 0.10 \\
\hline Trbs & Buckhorn Spring Rhyolite & 1.08 & 20.00 & 120.00 & 0.02 & 0.13 & 0.08 \\
\hline Trbb & Big Bend Rhyolite & 0.85 & 20.00 & 40.00 & 0.02 & 0.03 & 0.03 \\
\hline Trbc & Bridge Creek Rhyolite & 19.93 & 40.00 & 100.00 & 0.80 & 1.99 & 1.40 \\
\hline Trews & Elk Wallow Spring Rhyolite & 16.97 & 40.00 & 200.00 & 0.68 & 3.39 & 2.04 \\
\hline Trks & Kent Spring Rhyolite & 21.87 & 40.00 & 200.00 & 0.87 & 4.37 & 2.62 \\
\hline Trac & Antelope Creek Rhyolite & 11.65 & 3.00 & 70.00 & 0.03 & 0.82 & 0.43 \\
\hline Trec & Canyon Creek Rhyolite & 7.72 & 40.00 & 100.00 & 0.31 & 0.77 & 0.54 \\
\hline Trtes & Three Canyon Spring Rhyolite & 40.90 & 40.00 & 180.00 & 1.64 & 7.36 & 4.50 \\
\hline Trwm & Wolf Mountain Rhyolite & 59.45 & 50.00 & 200.00 & 2.97 & 11.89 & 7.43 \\
\hline Tdit4 & Dinner Creek Tuff, unit 4 & 3.26 & 3.00 & 8.00 & 0.01 & 0.03 & 0.02 \\
\hline Tdit2 & Dinner Creek Tuff, unit 2 & 2.18 & 3.00 & 10.00 & 0.01 & 0.02 & 0.01 \\
\hline Tdit1 & Dinner Creek Tuff, unit 1 & 20.23 & 3.00 & 30.00 & 0.06 & 0.61 & 0.33 \\
\hline Tmus & Mullen Spring Volcanic Clastics & 0.22 & 8.00 & 20.00 & 0.00 & 0.00 & 0.00 \\
\hline Thsd & Holdout Spring Dacite & 0.14 & 4.00 & 8.00 & 0.00 & 0.00 & 0.00 \\
\hline Itss & Clastic Sedimentary Rocks & 28.33 & 10.00 & 400.00 & 0.28 & 11.33 & 5.81 \\
\hline Kpm & Ultramafic Rocks & 0.31 & 3.00 & 10.00 & 0.00 & 0.00 & 0.00 \\
\hline \multicolumn{6}{|c|}{ Total area of all units: } & 464.75 & $\mathrm{~km} 2$ \\
\hline \multicolumn{6}{|c|}{ Total area of the SV Rhyolites: } & 180.79 & $\mathrm{~km} 2$ \\
\hline
\end{tabular}




\section{APPENDIX C:}

List of abbreviations found throughout this study. 


\section{LIST OF ABBREVIATIONS}

Map Units:

$\begin{array}{ll}\text { Qa } & \text { Qaternary Alluvium } \\ \text { Trst } & \text { Rattlesnake Tuff } \\ \text { Tdct } & \text { Devine Canyon Tuff } \\ \text { Tbsv } & \text { Basalt to Basaltic Andesite } \\ \text { Tpvd } & \text { Near Vent Pyroclastic Deposits } \\ \text { Tasv } & \text { Andesite of Strawberry Volcanics } \\ \text { Ttms } & \text { Milk Spring Tuff } \\ \text { Ttms1 } & \text { Milk Spring Tuff, unit 1 } \\ \text { Trbs } & \text { Buckhorn Spring Rhyolite } \\ \text { Trbb } & \text { Big Bend Rhyolite } \\ \text { Trbc } & \text { Bridge Creek Rhyolite } \\ \text { Trews } & \text { Elk Wallow Spring Rhyolite } \\ \text { Trks } & \text { Kent Spring Rhyolite } \\ \text { Trac } & \text { Antelope Creek Rhyolite } \\ \text { Trcc } & \text { Canyon Creek Rhyolite } \\ \text { Trtcs } & \text { Three Canyon Spring Rhyolite } \\ \text { Trwm } & \text { Wolf Mountain Rhyolite } \\ \text { Tdit4 } & \text { Dinner Creek Tuff, unit 4 } \\ \text { Tdit2 } & \text { Dinner Creek Tuff, unit 2 } \\ \text { Tdit1 } & \text { Dinner Creek Tuff, unit 1 } \\ \text { Tmus } & \text { Mullen Spring Volcanic Clastics } \\ \text { Thsd } & \text { Holdout Spring Dacite } \\ \text { Itss } & \text { Clastic Sedimentary Rocks } \\ \text { Kpm } & \text { Ultramafic Rocks } \\ & \end{array}$




\section{LIST OF ABBREVIATIONS}

Other Abbreviations Mentioned:

\begin{tabular}{ll}
\hline JOJM & Jump-off Joe Mountain Quadrangle \\
BC & Big Canyon Quadrangle \\
MPT & Magpie Table Quadrangle \\
LVW & Logan Valley West Quadrangle \\
SR & Strawberry Rhyolites \\
CRBG & Columbia River Basalt Group \\
HLP & High LavaPlains \\
XRF & X-ray fluorescence spectrometer \\
ICP-MS & Inductively coupled plasma mass spectrometry \\
ArcGIS & Aeronautical Reconnaissance Coverage Geographic Information System, made up of \\
& four fundamental applications with ArcMap being one for viewing and editing spatial \\
and geographic data. & Cross Polaried Light \\
XPL & Portland State University, Oregon USA \\
PSU & United States Geological Survey \\
USGS & Plane Polarized Light \\
PPL & EDMAP is the component of the NCGMP that funds universities to train the next \\
EDMAP & generation of geologic mappers. EDMAP is a one-year, mentor-guided program designed \\
& to teach students geologic mapping techniques through rigorous field mapping. Colleges \\
and universities in the United States and Puerto Rico are eligible to apply through an \\
annual competitive grants process. Every Federal dollar that is awarded is matched with
\end{tabular}




\section{APPENDIX D:}

Geologic Map of the Jump-Off Joe Mountain Quadrangle, Oregon, USGS EdMap project. (Dvorak, C.L. and Streck, M.J., 2018)

Geologic Map of the Big Canyon Quadrangle, Oregon, USGS EdMap project. (Dvorak, C.L. and Streck, M.J., 2018) 
GEOLOGIC MAP OF THE JUMP-OFF JOE QUADRANGLE, OREGON

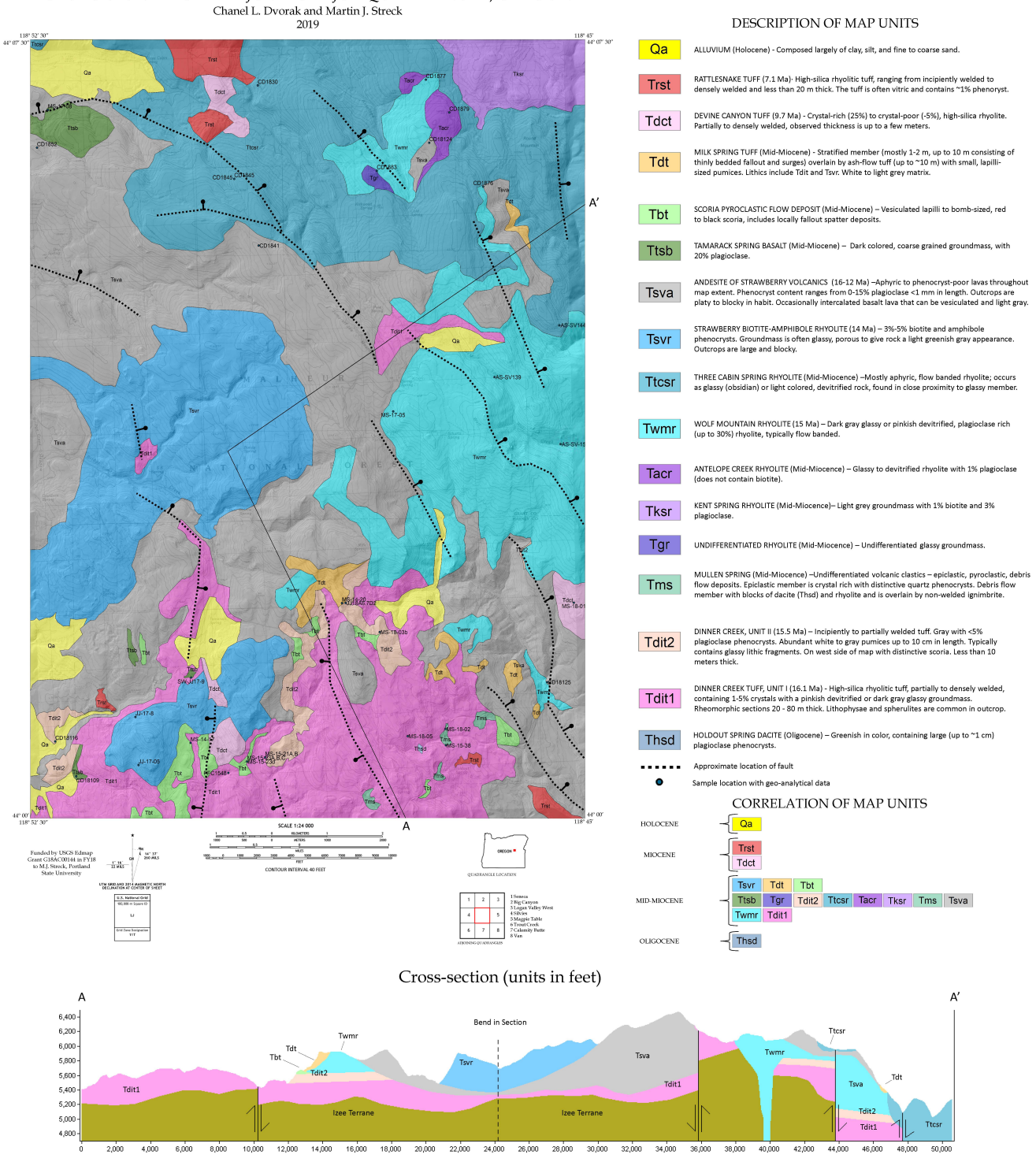




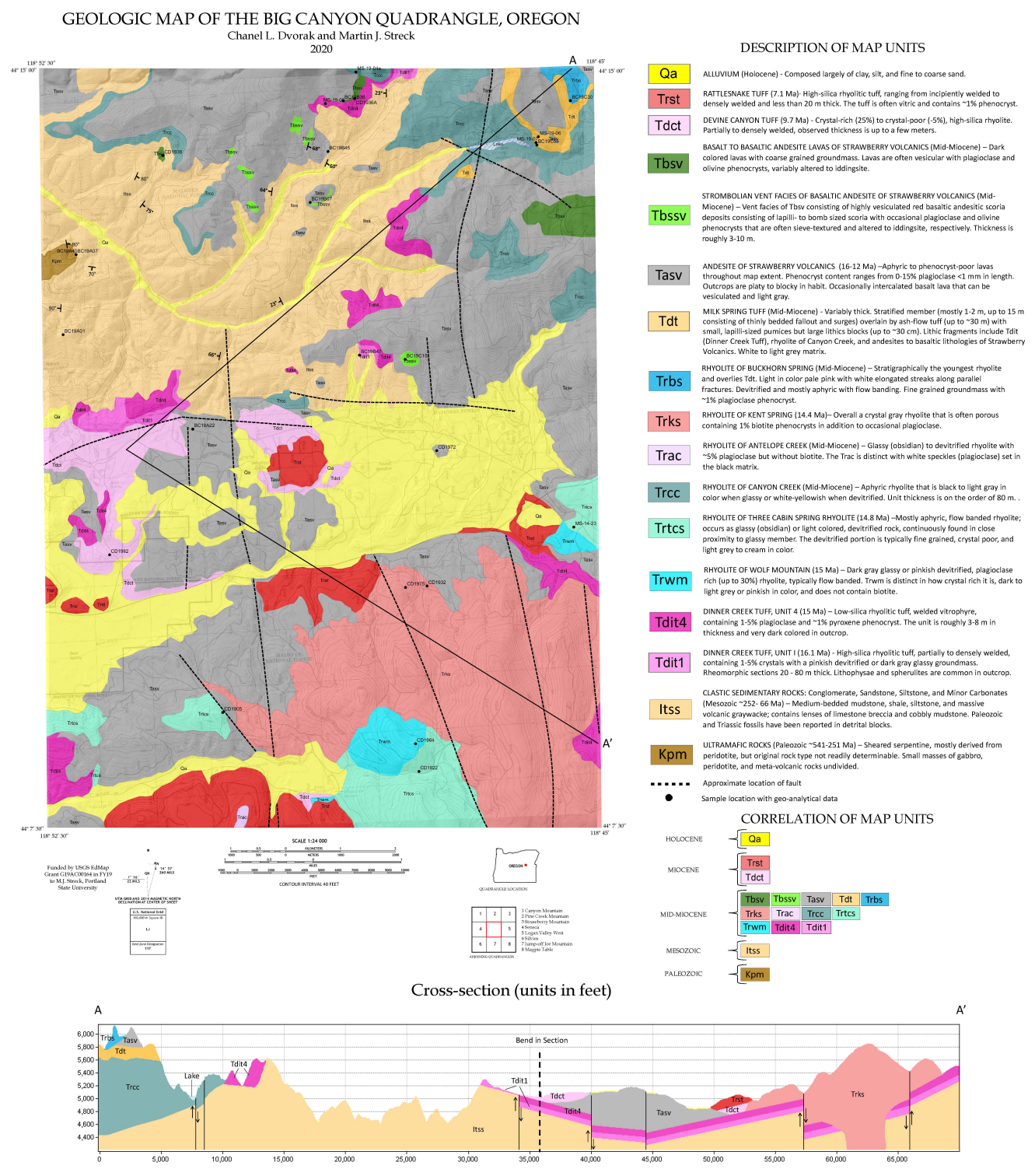

